BEATRIZ GODOI CAVALHEIRO

\title{
Expressão das metaloproteinases MMP-2, MT1-MMP e TIMP-2 e aspectos clinicopatológicos no carcinoma medular da glândula

\author{
tireóide: implicações prognósticas
}

\begin{abstract}
Tese apresentada à Faculdade de Medicina da Universidade de São Paulo para obtenção de título de Doutor em Ciências

Área de concentração: Clínica Cirúrgica

Orientador: Prof. Dr. Lenine Garcia Brandão
\end{abstract}

São Paulo 
Expressão das metaloproteinases MMP-2, MT1-MMP e TIMP-2 e aspectos clinicopatológicos no carcinoma medular da glândula tireóide: implicações prognósticas

Tese apresentada à Faculdade de Medicina da Universidade de São Paulo para obtenção de título de Doutor em Ciências

Área de concentração: Clínica Cirúrgica

Orientador: Prof. Dr. Lenine Garcia Brandão

São Paulo 
À minha família,

Cesar, Celina, Marcelo e Marcelo 


\section{Agradecimentos}

Ao meu pai, Dr. Cesar Augusto Cavalheiro, pelo exemplo e pelo infinito e incondicional apoio.

Ao Prof. Dr. Lenine Garcia Brandão, meu orientador e amigo, pela confiança em todos estes anos de trabalho conjunto.

À Prof ${ }^{\mathrm{a}}$. Dr ${ }^{\mathrm{a}}$. Consuelo Junqueira Rodrigues, pela fundamental participação no desenvolvimento desta tese.

Ao Prof. Dr. Dario Birolini, pela amizade e exemplo de dedicação.

Ao Prof. Dr. Alberto R. Ferraz, que permitiu minha admissão neste curso de pósgraduação.

À $\operatorname{Dr}^{\mathrm{a}}$. Marilza Cristina Legrazie Ezabella, pelo importante auxílio na identificação dos pacientes estudados.

Ao Prof. Dr. Uenes Tannuri, ao Dr. Guilherme Carvalhal Ribas e ao Dr. Edivaldo Utiyama, pelas imprescindíveis orientações no momento da qualificação deste trabalho.

À Sra. Maria das Graças Ribeiro Batista, do Laboratório de Investigações Médicas 02 da Faculdade de Medicina da USP, pelo incansável esforço no preparo das lâminas para a pesquisa.

Às Sras. Sandra de Moraes Fernezlian e Esmeralda Miristene Eher, do Laboratório de Imuno-Histoquímica do Departamento de Patologia da Faculdade de Medicina da USP, pela excelente confecção do material para estudo. 
Aos Srs. Douglas Moreira e Hermogênio Rafael de Oliveira, do Arquivo de Lâminas e Blocos da Divisão de Anatomia Patológica do Hospital das Clínicas da Faculdade de Medicina da USP.

À Sra. Valéria Vilhena, pela disponibilidade, pelo auxílio na aquisição das referências bibliográficas e pela elaboração da ficha catalográfica.

Às secretárias Leide Santos, Maria de Fátima Diniz, Marisa Conceição de Morais e Paula Lages Eduardo, sempre disponíveis e dispostas a orientar e auxiliar.

Aos colaboradores do Arquivo Médico do Hospital das Clínicas da Faculdade de Medicina da USP.

Aos pacientes, sem os quais nada disto faria sentido.

A todos os amigos e colegas do Serviço de Cirurgia de Cabeça e Pescoço do Hospital das Clínicas da Faculdade de Medicina da USP, especialmente ao Prof. Dr. Marcos Roberto Tavares, pelo apoio e inspiração quanto ao tema da tese, e ao Dr. Fábio de Menezes Montenegro, pelo auxílio na confecção de seu título, e àqueles que contribuíram, direta ou indiretamente, para este trabalho e cujo nome não foi citado, meu agradecimento. 


\section{Normalização adotada}

Esta tese está de acordo com:

Referências: adaptado de "International Committee of Medical Journals Editors (Vancouver).

Universidade de São Paulo. Faculdade de Medicina. Serviço de Biblioteca e Documentação. Guia de apresentação de dissertações, teses e monografias. Elaborado por Anneliese Carneiro da Cunha, Maria Júlia de A. L. Freddi, Maria F. Crestana, Marinalva de Souza Aragão, Suely Campos Cardoso, Valéria Vilhena. São Paulo: Serviço de Biblioteca e Documentação; 2004.

Abreviaturas dos títulos dos periódicos de acordo com "List of Journals Indexed in Index Medicus". 


\section{SUMÁRIO}

Lista de Abreviaturas

Lista de Siglas

Lista de Símbolos

Resumo

Summary

1 INTRODUÇÃO 01

1.1 Carcinoma medular da glândula tireóide 02

$\begin{array}{lll}1.2 & \text { Metaloproteinases } & 06\end{array}$

2 OBJETIVOS 08

3 REVISÃO BIBLIOGRÁFICA 10

3.1 Carcinoma medular da glândula tireóide 11

3.1.1 Aspectos etiológicos 11

$\begin{array}{lll}3.1 .2 & \text { Histopatogênese } & 15\end{array}$

3.1.3 Calcitonina e antígeno carcinoembrionário 16

3.1.4 Apresentações clínicas e relações genótipo-fenótipo 21

$\begin{array}{lll}3.1 .5 & \text { Estadiamento } & 30\end{array}$

3.1.6 Métodos diagnósticos 31

3.1.7 Rastreamentos familiar, bioquímico e genético 33

3.1.8 Tratamento 35

3.1.9 Seguimento pós-operatório e comportamento biológico 41

3.1.10 Sobrevida e fatores prognósticos 46

3.2 Metaloproteinases 53

3.2.1 A família das metaloproteinases 53

3.2.2 Carcinogênese e a participação das metaloproteinases 57

3.2.3 Regulação das metaloproteinases 61

3.2.4 Localização das metaloproteinases e inibidores teciduais das metaloproteinases 63 
3.2.5 Metaloproteinases e neoplasias da tireóide 68

3.2.6 Metaloproteinases e neoplasias de outros órgãos 75

$\begin{array}{lll}3.2 .7 & \text { Inibidores das metaloproteinases } & 77\end{array}$

4 MÉTODOS $\quad 79$

$\begin{array}{lll}4.1 & \text { Casuística } & 80\end{array}$

$\begin{array}{lll}4.2 & \text { Métodos } & 87\end{array}$

$\begin{array}{lll}4.3 & \text { Análise estatística } & 98\end{array}$

5 RESULTADOS 100

$\begin{array}{lll}5.1 & \text { Caracterização dos casos } & 101\end{array}$

$\begin{array}{lll}5.1 .1 & \text { Formas da doença } & 111\end{array}$

$\begin{array}{ll}5.1 .2 \text { Recidivas neoplásicas } & 115\end{array}$

$\begin{array}{lll}\text { 5.1.3 Persistências neoplásicas } & 116\end{array}$

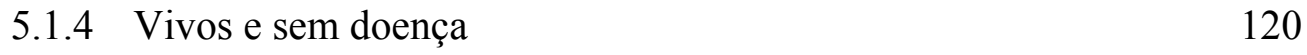

5.1.5 Óbitos 123

$\begin{array}{lll}\text { 5.1.6 Rastreamento } & 124\end{array}$

$\begin{array}{ll}\text { 5.1.7 Achados de exames } & 126\end{array}$

$\begin{array}{lll}\text { 5.1.8 Metástases a distância } & 128\end{array}$

$\begin{array}{lll}5.2 & 129\end{array}$

$\begin{array}{lll}5.3 & \text { Expressão de MT1-MMP } & 131\end{array}$

5.4 Expressão de TIMP-2 132

5.5 Análise estatística das variáveis clinicopatológicas 134

5.6 Análise estatística das variáveis relacionadas à marcação $\begin{array}{ll}\text { MMP-2 } & 145\end{array}$

5.7 Análise estatística das variáveis relacionadas à marcação

$\begin{array}{ll}\text { MT1-MMP } & 149\end{array}$

5.8 Análise estatística das variáveis relacionadas à marcação

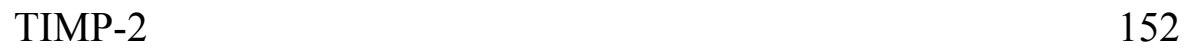

5.9 Análise estatística das variáveis relacionadas à razão de marcação MMP-2/TIMP-2 155

5.10 Análise de tempo livre de doença 158

5.11 Análise de sobrevida 159

6 DISCUSSÃO 161 
6.1 Variáveis clinicopatológicas 162

6.2 Variáveis relacionadas às marcações imuno-histoquímicas $\begin{array}{ll}\text { para metaloproteinases } & 192\end{array}$

7 CONCLUSÕES 213

8 ANEXOS 217

$\begin{array}{ll}\text { Anexo A } & 218\end{array}$

$\begin{array}{ll}\text { Anexo B } & 220\end{array}$

$\begin{array}{ll}\text { Anexo C } & 222\end{array}$

9 REFERÊNCIAS BIBLIOGRÁFICAS 226 


\section{Lista de Abreviaturas}

$\begin{array}{ll}\text { CT } & \text { Calcitonina } \\ \text { D } & \text { À direita } \\ \text { E } & \text { À esquerda } \\ \text { ed. } & \text { Edição } \\ \text { et al. } & \text { e outros } \\ \text { F } & \text { Sexo feminino } \\ \text { HPT } & \text { Hiperparatireoidismo } \\ \text { M } & \text { Sexo masculino } \\ \text { N } & \text { Não (no anexo C) } \\ \text { N } & \text { Número de pacientes (nas tabelas estatísticas) } \\ N^{o} & \text { Número } \\ \text { QT } & \text { Quimioterapia } \\ \text { p. } & \text { Página } \\ \text { R } & \text { Sim } \\ \text { RSG } & \text { Radioterapia } \\ & \text { Ultranografia } \\ & \end{array}$




\section{Lista de Siglas}

AJCC

APUD

CEA

CMT

CMT-E

CMT-F

CMTF-I

DNA

ELISA

EUA

HCC

HE

IC

$\mathrm{IH}$

MCD

MDL

MDM

MEC

MMP

m-RNA
“American Joint Committee on Cancer" ou Comitê Americano para o Câncer

"Amine Precursor Uptake and Decarboxylation" ou precursores de captação e decarboxilação de aminas

"Carcinoembrionnary Antigen" ou Antígeno

Carcinoembrionário

Carcinoma Medular da Tireóide

Carcinoma Medular da Tireóide Esporádico

Carcinoma Medular da Tireóide Familiar

Carcinoma Medular da Tireóide Familiar Isolado

“Deoxyribonucleic Acid” ou Ácido Desoxirribonucleico

"Enzyme-Linked Immunosorbent Assay"

Estados Unidos da América

Hiperplasia de Células "C"

Hematoxilina e Eosina

Intervalo de Confiança

Imuno-histoquímica

Morto com doença

Morto por doença local

Morto por doença metastática distante

Matriz Extracelular

“Matrix Metalloproteinase” ou Metaloproteinase

"Messenger Ribonucleic Acid" ou Ácido Ribonucléico Mensageiro 


\begin{tabular}{|c|c|}
\hline MT-MMP & $\begin{array}{l}\text { "Membrane Type Matrix } \\
\text { Metaloproteinase Transmembrana }\end{array}$ \\
\hline NEM & Neoplasias Endócrinas Múltiplas \\
\hline NEM1 & Neoplasias Endócrinas Múltiplas tipo 1 \\
\hline NEM2A & Neoplasias Endócrinas Múltiplas tipo 2A \\
\hline NEM2B & Neoplasias Endócrinas Múltiplas tipo 2B \\
\hline PAAF & Punção Aspirativa com Agulha Fina \\
\hline PBS & $\begin{array}{l}\text { "Phosphate-Buffered Saline" ou solução salina tamponada com } \\
\text { fosfatos }\end{array}$ \\
\hline RET & "Rearranged during Transfection" proto-oncogene \\
\hline ret & Proteína ret, transcrita pelo RET proto-oncogene \\
\hline RNA & "Ribonucleic Acid" ou ácido ribonucleico \\
\hline RR & Risco relativo \\
\hline TIMP & $\begin{array}{l}\text { "Tissue Inhibitor of Metalloproteinases" ou Inibidor Tecidual } \\
\text { de Metaloproteinases }\end{array}$ \\
\hline TNM & $\begin{array}{l}\text { Sistema de Estadiamento para o câncer: Tumor, Linfonodos } \\
\text { ("Nodes"), Metástases a distância }\end{array}$ \\
\hline VDL & Vivo e com doença local \\
\hline VDM & Vivo e com doença metastática distante \\
\hline VEGF & $\begin{array}{l}\text { "Vascular Endothelial Growth Factor" ou Fator de } \\
\text { Crescimento Endotelial Vascular }\end{array}$ \\
\hline VSD & Vivo e sem doença \\
\hline
\end{tabular}




\section{Lista de Símbolos}

$\begin{array}{ll}{ }^{\mathrm{cm}} \mathrm{C} & \text { centímetro } \\ \mathrm{kDa} & \text { grau Celsius } \\ > & \text { quilodalton } \\ \geq & \text { maior que } \\ \pm & \text { maior ou igual a } \\ < & \text { mais ou menos } \\ \leq & \text { menor que } \\ \mu \mathrm{m} & \text { menor ou igual a } \\ \mathrm{mm} & \text { micrômetro } \\ \mathrm{pg} / \mathrm{mL} & \text { milímetro } \\ \% & \text { picograma por mililitro } \\ \mathrm{X} & \text { por cento } \\ & \text { vezes de aumento (amplificação microscópica) }\end{array}$




\section{Resumo}

Cavalheiro BG. Expressão das metaloproteinases MMP-2, MT1-MMP e TIMP-2 e aspectos clinicopatológicos no carcinoma medular da glândula tireóide: implicações prognósticas [tese]. São Paulo: Faculdade de Medicina, Universidade de São Paulo; 2006. 242p.

INTRODUÇÃO: o carcinoma medular da tireóide é neoplasia de diferenciação e prognóstico intermediários, entre cânceres bem diferenciados e indiferenciados desta glândula, podendo ser esporádico ou familiar. O tratamento de escolha é cirúrgico. As metaloproteinases (MMP), por sua vez, são enzimas que participam diretamente da degradação da matriz extracelular, entre outros processos relacionados à carcinogênese. OBJETIVOS: correlacionar as evoluções clínicas de 37 pacientes, submetidos a tratamento operatório para o carcinoma medular, com dados clinicopatológicos, obtidos em revisões de prontuários médicos, e com as expressões imuno-histoquímicas, nos espécimes tumorais, de MMP-2, MT1-MMP (MMP transmembrana 1) e TIMP-2 (inibidor tecidual 2 de MMP), associados à progressão neoplásica em outros sítios. MÉTODOS: são 37 pacientes acompanhados por 65,62 meses em média (quatro a 189 meses), em período de junho de 1982 a fevereiro de 2005, nos Serviços de Cirurgia de Cabeça e Pescoço e Endocrinologia do Hospital das Clínicas da Faculdade de Medicina da Universidade de São Paulo, no Instituto Brasileiro de Controle do Câncer e em clínica privada. Os blocos operatórios foram selecionados conforme sua representação neoplásica e as colorações imunohistoquímicas realizadas com os marcadores citados acima. Análise estatística foi realizada com associação de significância ao nível de 5,0\%. RESULTADOS: quinze pacientes $(40,5 \%)$ curaram-se e encontravam-se vivos e sem doença ao final dos seguimentos clínicos. Dezessete (45,9\%) apresentaram persistências neoplásicas e, em cinco $(13,5 \%)$, as neoplasias recidivaram. Quatro pacientes $(10,8 \%)$ faleceram, todos em decorrência do carcinoma medular e com indícios clínicos e/ou imagenológicos de neoplasia. Das relações entre condições clínicas finais (vivo sem doença, vivo com doença e morto pela doença) e aspectos clinicopatológicos, foram estatisticamente significativos: exame físico cervical inicial positivo quanto à presença de nódulos tireóideos e/ou adenomegalia metastática $(\mathrm{p}=0,0017)$, sintomas sistêmicos $(\mathrm{p}=0,0288)$, extensão neoplásica para a cápsula tireóidea $(\mathrm{p}=0,0375)$, extensão tumoral para tecidos adjacentes $(p=0,0024)$, invasão vascular $(p=0,0142)$, acometimento metastático linfonodal cervical $(\mathrm{p}<0,0001)$, estádio TNM ( $\mathrm{p}=$ $0,0016)$ e evidências de doenças cervical e/ou a distância na ausência de cura $(\mathrm{p}=$ 0,0335). Índice proposto (associação de proporção de área neoplásica imunomarcada e intensidade desta coloração) correlacionou-se, quando aplicado às expressões de MMP-2 em neoplasias primárias, às condições clínicas finais $(\mathrm{p}=0,0005)$ e às evoluções com cura ou persistência neoplásica após o tratamento cirúrgico inicial ( $\mathrm{p}$ $=0,0207)$. O mesmo índice, aplicado às expressões de MT1-MMP, bem como, a proporção de células neoplásicas imunocoradas, correlacionou-se com possibilidades de cura ou persistência $(\mathrm{p}=0,0098)$. Após cálculo de razão entre expressões imunohistoquímicas de MMP-2 e TIMP-2 em neoplasias primárias, foi observado que maior proporção deste último correlacionou-se com menores ocorrências de: exame cervical inicial positivo $(p=0,0248)$, metástases linfonodais cervicais $(p=0,0002)$ e 
condições clínicas finais desfavoráveis $(\mathrm{p}=0,0149)$. CONCLUSÕES: aspectos clinicopatológicos e expressões imuno-histoquímicas de MMP-2 e MT1-MMP, bem como a razão entre MMP-2 e seu inibidor tecidual TIMP-2, são preditores adicionais de evolução clínica em portadores de carcinomas medulares tratados cirurgicamente.

Descritores: 1.CARCINOMA MEDULAR 2.NEOPLASIAS DA GLÂNDULA TIREÓIDE 3.METALOPROTEASES 4.GELATINASE A 5.INIBIDOR DE METALOPROTEINASE-2 TECIDUAL 6.PROGNÓSTICO 7.IMUNOHISTOQÍMICA 


\section{Summary}

Cavalheiro BG. Expression of matrix metalloproteinases MMP-2, TIMP-2 e MT1MMP and clinicopathologic aspects in medullary thyroid carcinoma: prognostic implications [tese]. São Paulo: Faculdade de Medicina, Universidade de São Paulo; 2005. 242p.

INTRODUCTION: medullary thyroid carcinoma is neoplasia of intermediary differentiation and prognosis, between differentiated and undifferentiated thyroid cancers. It may be sporadic or familiar. Its treatment of choice is surgical. Matrix metalloproteinases (MMP) are enzymes that participate directly in the degeneration of the extracellular matrix, among other processes related to carcinogenesis. OBJECTIVES: correlate the clinical evolution of 37 patients submitted to surgical treatment for medullary carcinoma, with clinicopathologic data, obtained in reviews of medical promptuaries, and with neoplastic immunohistochemical expressions of MMP-2, MT1-MMP (membrane type 1 MMP) and TIMP-2 (tissue inhibitor 2 of MMP), associated to the neoplastic progression in other sites. METHODS: 37 patients followed up for 65.62 months on average (four to 189 months), during the period from June 1982 to February 2005, in the Services of Head and Neck Surgery and Endocrinology of the Hospital das Clínicas of the University of São Paulo Medical School, in the Brazilian Institute of Cancer Control and in private clinics. The surgical paraffin blocks were selected according to their neoplastic representation and the immunohistochemical stainings carried out with the markers cited above. Statistical analysis was performed with the association of a level of significance of 5.0\%. RESULTS: fifteen patients (40.5\%) were cured and were found live and without the disease at the end of the clinical procedures. Seventeen (45.9\%) presented neoplastic persistence and, in five (13.5\%), the neoplasia relapsed. Four patients $(10.8 \%)$ deceased, all of them due to medullary carcinoma and with clinical and/or imagenological evidences of neoplasia. Of the relations between the final clinical conditions (live without disease, live with disease and dead due to the disease) and clinicopathologic aspects, were statistically significant: initial cervical examination positive to the presence of thyroid nodules and/or metastatic lymph nodes $(p=0.0017)$, systemic symptoms $(p=0.0288)$, neoplastic extension for the thyroid capsule $(p=0.0375)$, tumor extension to adjacent tissues $(p=0.0024)$, vascular invasion $(p=0.0142)$, cervical lymph nodes metastases $(p<0.0001)$, TNM stage $(p=0.0016)$ and evidence of cervical disease and/or distant metastases in the absence of cure $(p=0.0335)$. The score system proposed (association of the proportion of neoplastic immunomarked area and the intensity of this staining) was correlated, when applied to the MMP-2 expressions in primary neoplasias, with final clinical conditions $(p=0.0005)$ and with evolutions, determined by cure or neoplastic persistence, after initial surgical treatment $(p=0,0207)$. The same score, applied to the MT1-MMP expressions, as well as the proportion of immunostained neoplastic cells, was correlated with possibilities of cure or persistence $(p=0.0098)$. After calculating the rate between the MMP-2 and TIMP-2 immunohistochemical expressions in primary neoplasias, greater proportion of the latter was correlated with lesser occurrences of: initial positive cervical examination $(p=0.0248)$, cervical lymph nodes metastases $(p=0.0002)$ and final unfavorable clinical conditions $(p=$ 
0.0149). CONCLUSIONS: clinicopathologic aspects and immunohistochemical expressions of MMP-2 and MT1-MMP, as well as the rate between MMP-2 and its tissue inhibitor TIMP-2, are additional indicators of clinical evolution in bearers of medullary carcinomas treated surgically.

Indicators: 1.MEDULLARY CARCINOMA 2.THYROID NEOPLASMS 3.METALLOPROTEASES 4.GELATINASE A 5.TISSUE INHIBITOR OF METALLOPROTEINASE-2 6.PROGNOSIS 7.IMMUNOHISTOCHEMISTRY 
1 INTRODUÇÃO 


\section{INTRODUÇÃO}

\subsection{CARCINOMA MEDULAR DA GLÂNDULA TIREÓIDE}

O carcinoma medular da glândula tireóide (CMT) é uma neoplasia de diferenciação intermediária entre aquelas bem diferenciadas, como os carcinomas papilífero e folicular, e cânceres indiferenciados ou anaplásicos desta glândula. É responsável por $3 \%$ a $15 \%$ dos tumores malignos da tireóide. ${ }^{1-6}$

Em estudo retrospectivo conduzido por Saad et al. ${ }^{1}$ com 1844 portadores de carcinomas da tireóide, 8,7\% eram acometidos por CMT. Já, entre 5584 portadores de carcinomas da tireóide tratados nos Estados Unidos durante 1996, 3,17\% apresentavam esse tumor. ${ }^{2}$ Entre 53856 casos de carcinomas da tireóide, estudados com dados fornecidos por aproximadamente 2100 hospitais do território norteamericano, foram identificados 3,7\% de casos de CMT entre 1985 e 1990 e, 3,5\%, entre 1991 e $1995 .^{3}$

Pacini et al. ${ }^{4}$ estudaram 1385 portadores de nódulos tireóideos, atendidos consecutivamente durante 12 meses. Foram diagnosticados $0,57 \%$ de CMTs, que corresponderam a $15,7 \%$ de todos os casos de carcinomas da tireóide. Bisi et al., ${ }^{5} \mathrm{em}$ revisão histórica de cinco décadas (de 1945 a 1989) realizada com material de 281175 pacientes operados no Hospital das Clínicas da Faculdade de Medicina da Universidade de São Paulo, identificaram 542 casos de neoplasias malignas 
primárias da glândula tireóide, entre os quais observaram 16 casos de CMT (2,95\%). Através de base de dados coletados entre 1988 e 1998 , Bhattacharyya ${ }^{6}$ identificou $499(2,8 \%)$ pacientes acometidos por CMTs, entre 18118 casos de carcinomas diferenciados e medulares da tireóide tratados nos EUA no período acima.

Há tendência de maior acometimento de mulheres com proporções que não ultrapassam 2,5 mulheres para cada homem afetado. ${ }^{1,2,6-17}$ Faixas etárias acometidas são muito diversas e correlacionam-se com a forma clínica da doença, o que implica indivíduos cujas primeiras manifestações do CMT podem ocorrer desde à primeira década de vida até à sexta década ou ainda mais adiante.

O CMT origina-se de células " $\mathrm{C}$ " da tireóide, originalmente denominadas células parafoliculares e derivadas da crista neuroectodérmica, precursora do sistema nervoso central. São células do sistema APUD ("Amine Precursor Uptake and Decarboxylation" ou precursores de captação e decarboxilação de aminas), produtoras de aminas e outros peptídeos.

Em 1951, Horn ${ }^{18}$ descreveu variante distinta do carcinoma tireóideo representada por grupos celulares compactos e peculiar tendência ao desenvolvimento de metástases linfonodais. Mas foram Hazard et al. ${ }^{19}$ que caracterizaram, em 1959, o CMT como entidade clinicopatológica, definiram suas características histológicas relevantes, inclusive a presença de amilóide e seu padrão não-folicular, e sugeriram sua denominação. Em 1965, Schimke e Hartmann 20 observaram associação de caráter familiar autossômico dominante entre CMT e feocromocitoma. Sipple, ${ }^{21}$ porém, já havia notado relação entre carcinoma tireóideo e feocromocitoma bilateral, em 1961. Já Williams, ${ }^{22}$ em 1966, atribuiu a origem do CMT às células parafoliculares, células estas descritas como presentes entre o 
epitélio folicular e a membrana basal do folículo tireóideo, próximas à parede externa do folículo. Em 1968, Steiner et al. ${ }^{23}$ descreveram associação entre CMT, feocromocitoma e hiperparatireoidismo (HPT), síncronos ou não, como parte da Síndrome das Neoplasias Endócrinas Múltiplas (NEM) tipo 2.

Em 1968, Tashjian e Melvin ${ }^{24}$ dosaram, pela primeira vez, títulos séricos e teciduais de calcitonina (CT) em paciente com CMT e em seu espécime tumoral, respectivamente, e, desde 1978, essa tem sido utilizada como marcador diagnóstico e prognóstico, sensível e específico para o CMT. ${ }^{4}$

Simpson et al., ${ }^{25}$ seguidos por Mathew et al., ${ }^{26}$ identificaram o cromossomo 10q11.2 como sede das alterações genéticas responsáveis pela Síndrome das Neoplasias Endócrinas Múltiplas tipo 2A (NEM2A). Em 1993, Mulligan et al. ${ }^{27} \mathrm{e}$ Donis-Keller et al. ${ }^{28}$ identificaram que mutações germinativas no RET ("Rearranged during Transfection") proto-oncogene, codificador de receptor tirosino-quinase na membrana celular, são responsáveis pelos carcinomas medulares tipo familiar isolado (CMTF-I) e relacionado à NEM2A e introduziram o teste genético na prática clínica. Relações entre mutações no RET proto-oncogene e a Síndrome das Neoplasias Endócrinas Múltiplas tipo 2B (NEM2B) foram estabelecidas em 1994. ${ }^{29}$ Desde então, mutações em diferentes códons cromossômicos têm sido associadas às NEMs e ao CMTF-I. Foram feitas, também, correlações genótipo-fenótipo, ou seja, mutações específicas no RET proto-oncogene levam a padrões próprios de manifestações clínicas. ${ }^{30-33}$

Grupos de estudo multinacionais têm contribuído com muito das informações disponíveis a respeito do CMT e das NEMs, com destaque para os "International RET Mutation Consortium”, “European Multiple Endocrine Neoplasia (EUROMEN) 
Study Group", 34 “Groupe D’Étude dês Tumeurs à Calcitonine” (GETC), "13 "U.S. Thyroid Cancer Study Group" e "German Thyroid Study Group". 2 Avanços na compreensão da origem genética do CMT têm proporcionado aprimoramentos no diagnóstico de suas formas clínicas e promovido o desenvolvimento de programas de rastreamento familiar para diagnóstico precoce da doença, antes mesmo que esta se manifeste. $^{35}$

Aproximadamente $75 \%$ dos casos de CMT ocorrem de forma não-herdada, ou seja, esporádica (CMT-E), em indivíduos, em geral, com mais de 30 anos de idade e sem endocrinopatias associadas. Os demais $25 \%$ dos casos ocorrem sob forma herdada, a partir de mutações no RET proto-oncogene, e constituem a forma familiar do CMT (CMT-F). Sua transmissão é autossômica dominante, com alta penetrância e expressividade variável e idade-dependente. ${ }^{35}$ A forma familiar da doença pode ser dividida em quatro entidades distintas: vinculada à NEM2A; vinculada a um subtipo da NEM2A, associada à presença de lesões cutâneas de líquen de amiloidose; vinculada à NEM2B e como CMT isolado (CMTF-I), onde a transmissão da doença também é autossômica dominante, mas não se manifestam outras endocrinopatias. ${ }^{8}$ Os pacientes acometidos são mais jovens e o desenvolvimento de hiperplasia de células "C" (HCC) precede o carcinoma, que tende a manifestar-se de forma multifocal. O diagnóstico das formas familiares tem se beneficiado com o desenvolvimento de conhecimentos genéticos, de tal forma que sua proporção tende a aumentar em relação ao CMT-E. À NEM2A associam-se, além do CMT, feocromocitoma e HPT. À NEM2B estão associados feocromocitoma, neuromas mucosos e anormalidades esqueléticas, sendo a ocorrência de HPT muito rara. ${ }^{8}$ 
O único tratamento eficaz é cirúrgico, principalmente se realizado em estádios precoces da doença. Assim como suas formas clínicas, o prognóstico dos portadores de CMT também é muito variável. Sobrevida global, em cinco anos, já foi calculada entre $65 \%$ e $100 \% .{ }^{6,8,10,17}$ Recidivas podem ocorrer a longo prazo e não há dúvida de que se trata de doença de evolução potencialmente fatal.

\subsection{METALOPROTEINASES}

A matriz extracelular (MEC) desenvolve papel crucial no desenvolvimento e na manutenção da arquitetura tridimensional tecidual. Da perda da integridade dos tecidos, participa a desintegração desse arcabouço, cuja remodelação, por sua vez, é essencial tanto para processos fisiológicos (remodelação óssea, implantação trofoblástica e cicatrização, por exemplo), como para processos patológicos (doenças inflamatórias e carcinogênese). ${ }^{36}$ Células neoplásicas requerem degradação proteolítica da MEC para cada etapa da carcinogênese, que inclui organização da neoplasia primária, sua progressão, angiogênese, invasão local e desenvolvimento de metástases. ${ }^{37}$ Os componentes da MEC incluem colágenos, lamininas, fibronectina, vitronectina e proteoglicanos. ${ }^{38}$

Proteinases extracelulares participam de todas essas etapas, sendo que suas habilidades de degradação são essenciais para que cada célula interaja de forma apropriada com o meio que a circunda. ${ }^{38}$ Existem diversas famílias de enzimas que degradam a MEC, destaca-se, pela extensa participação em praticamente todos os 
passos da carcinogênese e capacidade de degradação de todos os componentes da MEC, a família das metaloproteinases ("Matrix Metalloproteinases” ou MMPs), ${ }^{36,39}$ também denominadas matrixinas.

MMPs são definidas como proteinases que degradam componentes da MEC e da membrana basal, contém um íon zinco, compartilham seqüências comuns de aminoácidos, são produzidas sob forma latente (zimogênio) e são inutilizadas pelos inibidores teciduais das metaloproteinases ("Tissue Inhibitors of Metalloproteinases" ou TIMPs). ${ }^{36}$ Exercem também participações essenciais em funções fisiológicas, como remodelações e reparos teciduais, morfogênese e angiogênese. ${ }^{40}$

Diversos estudos, que serão citados em capítulos posteriores, relacionaram a expressão das MMPs em tecidos neoplásicos ao comprometimento prognóstico de seus respectivos portadores. São poucas as publicações que correlacionaram o câncer tireóideo, especialmente o carcinoma medular, à expressão das MMP. Somente uma linha de pesquisa, ${ }^{37}$ até o momento, tentou associar a expressão de MMP-2 em espécimes de CMT ao estádio patológico, sem sucesso, porém. Com o presente estudo, objetiva-se correlacionar as expressões imuno-histoquímicas (IH) das MMP2 e MT1-MMP (“Membrane Type 1 Matrix Metalloproteinase”, metaloproteinase transmembrana 1 ou MMP-14) e do TIMP-2 (inibidor tecidual 2 da MMP) no carcinoma medular a aspectos clinicopatológicos a serem também testados como pertinentes, ou não, à evolução dos pacientes estudados. Foram selecionados 37 casos, seguidos por 65,62 meses em média (quatro a 189 meses). 
2 OBJETIVOS 


\section{OBJETIVOS}

O presente estudo teve como objetivo a análise retrospectiva de 37 casos de CMTs, assim como de seus espécimes operatórios. Foram revistos os prontuários médicos dos respectivos pacientes em busca de dados clinicopatológicos e, através de colorações IH para MMP-2, MT1-MMP (MMP-14) e TIMP-2, pretendeu-se determinar suas expressões em espécimes neoplásicos primários e metastáticos, estes últimos quando existentes, e comparar os dados obtidos com a evolução clínica de cada paciente estudado. Pretendeu-se avaliar a aplicabilidade do estudo imunohistoquímico proposto como método preditivo do comportamento biológico do CMT e, em outras palavras, responder às seguintes questões:

1. Há correlação entre aspectos clinicopatológicos e as condições clínicas finais - vivo sem doença, vivo com doença ou morto pela doença?

2. Há correlação entre aspectos clinicopatológicos e as evoluções clínicas após os tratamentos cirúrgicos iniciais - cura ou persistência/recidiva neoplásica?

3. Há correlação entre as representações imuno-histoquímicas das proteínas MMP-2, MT1-MMP e TIMP-2 nos espécimes cirúrgicos e as evoluções pósoperatórias dos pacientes, bem como suas condições clínicas finais? 
3 REVISÃO BIBLIOGRÁFICA 
3 REVISÃO BIBLIOGRÁFICA

\subsection{CARCINOMA MEDULAR DA GLÂNDULA TIREÓIDE}

\subsubsection{ASPECTOS ETIOLÓGICOS}

Existem duas classes de genes cujas mutações, desenvolvendo-se naturalmente ou por influência de carcinógenos, levam à perda do controle do crescimento e divisão celulares que culminam com o desenvolvimento do câncer. São eles os genes supressores de tumores e os oncogenes. Múltiplos eventos genéticos seqüenciais, entretanto, são necessários para o desenvolvimento das neoplasias. ${ }^{41}$

Mais de 100 oncogenes já foram descritos e, por definição, caracterizam-se por efeito "ganho de função", quando um proto-oncogene torna-se inapropriadamente ativado através de mutações. Tal ativação altera o produto da expressão gênica a partir de elevada expressividade ou incapacidade de regulação transcricional. É improvável que a ativação de um oncogene isolado leve ao desenvolvimento clínico do câncer, mas parece ser o evento inicial na carcinogênese tireóidea, seguida de outros eventos moleculares que culminam em fenótipos 
malignos. Genes supressores de tumores, por sua vez, participam do desenvolvimento do câncer a partir de efeito "perda de função". 41

Knudson et al. ${ }^{42}$ propuseram teoria para a carcinogênese do CMT baseada em dois eventos mutacionais. O primeiro evento seria a mutação germinativa, herdada de forma autossômica dominante, nas células precursoras da crista neural e que tornaria as células descendentes susceptíveis à transformação maligna. $O$ segundo evento corresponderia a mutações somáticas no clone hiperplásico com resultante desenvolvimento do carcinoma. Ressalta-se que mutações germinativas são identificadas no material genético de todas as células do organismo, enquanto que mutações somáticas são eventos restritos às células neoplásicas.

O RET proto-oncogene, localizado em posição pericentrométrica no cromossomo 10, codifica a proteína ret, glicoproteína da membrana celular, receptora de fatores de crescimento e composta por domínio tirosino-quinase. Mutações levam à ativação desta proteína com conseqüências carcinogênicas a favor do CMT e que também podem contribuir para o desenvolvimento do carcinoma papilífero da tireóide, através de rearranjos somáticos, não-hereditários. ${ }^{43,44}$

São relatadas diversas mutações, na sua maioria pontuais (alterações únicas em base do nucleotídeo), responsáveis pela ativação da proteína ret e pela maioria dos casos de CMT, porém ainda há muito o quê se compreender a respeito de aspectos biológicos deste tumor. Kim et al. ${ }^{45}$ enfatizaram algumas questões interessantes a respeito do CMT e das NEMs: por que órgãos específicos são afetados pelos defeitos genéticos germinativos enquanto outros não o são? Por que algumas neoplasias induzidas são malignas, entre outras benignas? E o que pode ser feito para se inibir a proliferação das células afetadas? 
Nas formas familiares, a HCC associa-se ao ou precede o desenvolvimento do CMT. Especula-se que a HCC seja induzida por mutações germinativas no RET, mas que requeira eventos somáticos adicionais para sua progressão para CMT. ${ }^{46}$

Mutações em códons específicos (seqüências de três nucleotídeos que codificam aminoácidos, em molécula de DNA ou RNA) têm sido associadas às diferentes manifestações do CMT, tanto relacionadas às formas clínicas, como ao comportamento biológico neoplásico, que pode ser distinto entre famílias alocadas em uma mesma síndrome. Mutações em códons específicos correlacionam-se com alterações de domínios também específicos da proteína tirosino-quinase com conseqüências fenotípicas próprias. Mutações germinativas no RET proto-oncogene foram identificadas em aproximadamente $97 \%$ dos portadores de NEM2A, 95\% dos portadores de NEM2B e em $86 \%$ dos portadores de CMTF-I. ${ }^{35}$

Machens et al. ${ }^{46}$ estudaram 167 portadores de mutações germinativas do RET proto-oncogene e submetidos à tireoidectomia total. Sessenta e sete pacientes foram considerados casos "index", ou primeiro caso diagnosticado em determinada família, e os 100 restantes diagnosticados por rastreamento genético. Trinta e sete por cento das famílias afetadas o eram no códon 634 - éxon 11, 19\% no códon 918 éxon $16,10 \%$ no códon 790 - éxon $13,9 \%$ no códon 618 - éxon $10,8 \%$ no códon 620 - éxon 10, 7\% no códon 791 - éxon 13, 4\% no códon 804 - éxon 14, 3\% no códon 611 - éxon 10, 2\% no códon 768 - éxon 13 e 1\% no códon 630 - éxon 11, sendo éxons seqüências codificadoras do material genético, compostas por códons. No momento da operação, fenótipos relacionados às NEM2s já eram presentes nos portadores de mutações nos códons 918 (100\%), 634 (26\%), 620 (17\%), 791 (13\%) e 
618 (11\%). Idades de surgimento do CMT foram muito distintas entre os pacientes e correlacionaram-se ao códon acometido pela mutação.

Em estudo com 94 famílias portadoras de mutação no RET, Frank-Raue et al. 31 observaram que $81 \%$ dos acometidos pela NEM2A apresentavam mutação no códon 634, associada a maior prevalência de feocromocitoma e HPT. Em metade dos acometidos pelo CMTF-I, foram identificadas mutações no códon 634. De oito pacientes acometidos pela NEM2B, apenas um não apresentava mutações germinativas no códon 918 do RET proto-oncogene, mutação considerada, quando germinativa, específica para o desenvolvimento da NEM2B.

Com dados coletados de 18 instituições médicas, 477 famílias NEM2 foram avaliadas notando-se que mutações no códon 918 só ocorreram nos casos de NEM2B e mutações nos códons 768 e 804 foram mais freqüentes nos acometidos pelo CMTF-I. Doença de Hirschsprung também pode estar associada a mutações no RET proto-oncogene e sua presença foi relatada no estudo. ${ }^{32}$

Setenta e nove por cento das crianças e adolescentes estudados, entre 75 portadores de mutações no RET, apresentavam mutações no códon $634 .{ }^{47}$ Em revisão da literatura, Szinnai et al. ${ }^{48}$ identificaram, entre 150 pacientes pediátricos, $63 \%$ de casos relacionados a mutações no códon $634,19 \%$ no códon $618,9 \%$ no códon 620 e 6\% no códon 804. Foram encontrados raros casos de mutações nos códons 609, 611 e 790.

Dos acometidos pela NEM2A, sua maioria é portadora de mutações em códons dos éxons 10 e 11, que levam a alterações no domínio extracelular da proteína ret. Dos portadores da NEM2B, cerca de 95\% apresentam mutações no códon 918 e os demais são acometidos, em sua maioria, por mutações no códon 883 - 
éxon 15. Ambos os códons produzem alterações no domínio intracelular da proteína ret. ${ }^{49}$ Pelo CMTF-I, são responsabilizadas mutações que envolvem tanto domínios extra, como intracelulares, da proteína ret.

Alterações somente somáticas no RET proto-oncogene têm sido correlacionadas ao CMT-E em $23 \%$ a $69 \%$ dos casos. A mutação mais freqüente localiza-se no códon $918 .{ }^{50,51}$ É distribuída de maneira heterogênea no mesmo espécime neoplásico e assim não parece ser evento inicial na carcinogênese da forma esporádica do tumor. ${ }^{51}$ Mutações somáticas também foram encontradas nos éxons 10,11 e $15 .^{52}$

\subsubsection{HISTOPATOGÊNESE}

A hiperplasia de células "C" é condição caracterizada pela proliferação multifocal destas células, com respeito à membrana basal do folículo tireóideo. ${ }^{53}$ Pode ser definida por densidade de células "C" maior que 40 células por centímetro cúbico por campo de aumento de $400 \mathrm{X}$ ou, pelo menos, três focos microscópicos de células "C" que contenham mais que 50 células por campo de aumento de $100 \mathrm{X}$. As lâminas devem estar coradas com calcitonina (técnica imuno-histoquímica). ${ }^{54}$

A HCC pode estar presente em várias condições clínicas, como NEM2, situações de hipercalcemia, condições de hipergastrinemia, tireoidite de Hashimoto, bócio hiperplásico e adjacente a outros tumores tireóideos. Embora seja mais 
freqüente no CMT-F, observa-se que não é exclusiva das formas familiares, onde é considerada precursora do CMT. ${ }^{53}$

O CMT precoce é diagnosticado pelo acometimento da membrana basal folicular, o que pode incluir interrupções focais ou pontos de duplicação da mesma, visualizados após coloração IH ou à microscopia eletrônica. Há, portanto, extensão de células "C" para o interstício tireóideo. ${ }^{53}$

A maioria dos carcinomas medulares não é encapsulada e exibe amplo espectro arquitetural. Os padrões morfológicos celulares também são vários. Nos casos familiares, lesões pequenas são mais freqüentemente encontradas na transição dos terços médio e superior dos lobos tireóideos, onde predominam as células "C" em condições fisiológicas. Metástases contralaterais podem ser confundidas com multicentricidade neoplásica, mais comum nos casos familiares, embora não existam diferenças histopatológicas entre as entidades familiar e esporádica. A presença de HCC adjacente a tais lesões é mais freqüente em tumores primários, nãometastáticos. ${ }^{53}$ Depósitos de amilóide no estroma são constantes, como também variáveis quantidades de colágeno e áreas de calcificações. ${ }^{1,53}$

\subsubsection{CALCITONINA E ANTÍGENO CARCINOEMBRIONÁRIO}

Calcitonina é polipeptídeo produzido pelas células " $\mathrm{C}$ " da tireóide e com poder hipocalcemiante, antagônico, portanto, ao paratormônio humano (PTH) produzido pelas paratireóides. ${ }^{55}$ É marcador bastante sensível e específico de 
processos patológicos das células "C", embora outras condições clínicas também possam estar associadas a níveis séricos elevados de CT, como outros "APUDomas" (ganglioneuromas, neuroblastomas, timomas, tumores carcinóides como do pulmão e do trato gastrointestinal), câncer de mama, câncer de próstata, hipercalcemia, hipocalcemia neonatal, insuficiência renal, insuficiência hepática, pancreatite, doença de Graves, doença péptica aguda, anemia perniciosa, estresse, operação da glândula tireóide, operação hepática, infarto agudo do miocárdio, traumas, intoxicação por lítio, gestação e lactação. É o principal polipeptídeo produzido pelas células "C" e homens têm concentrações séricas mais elevadas, como também indivíduos durante o crescimento estatural. $^{8}$

Sua secreção é influenciada por secretagogos entre os quais se destacam etanol, gastrina, pentagastrina, isoproterenol, estrógenos, testosterona, vitamina D, cálcio, catecolaminas e opióides. Cimetidina, nicotina, somatostatina, CT exógena e ß-bloqueadores inibem a liberação de CT. Testes com secretagogos (testes de estímulo ou provocativos) aperfeiçoaram a detecção de valores séricos alterados de CT e o diagnóstico do CMT, com redução de resultados falso-negativos. Os testes preferenciais combinam infusão de cálcio seguida de infusão de pentagastrina, com dosagens de CT previamente ao exame, no tempo zero e em intervalos de um, dois, cinco, 10 e 15 minutos. São de grande valia em casos de HCC, em CMTs de dimensões pequenas e na presença de restos tumorais após ressecção operatória, quando dosagens de CT basal podem encontrar-se dentro dos limites da normalidade. Testes provocativos com resultados limítrofes devem ser repetidos mais duas vezes, no mínimo. ${ }^{8}$ Não há consenso universal quanto aos valores específicos para os 
níveis fisiológicos e patológicos de CT sérica, de tal forma que cada laboratório deve padronizar seus valores de referência. ${ }^{8,34}$

Como a meia vida da CT é muito baixa, seus títulos séricos devem normalizar-se entre 24 e 72 horas, após tratamento cirúrgico satisfatório. Evidência de níveis elevados de CT a partir de 72 horas da operação, apesar de reduzidos em relação aos valores pré-operatórios, pode indicar persistência de doença neoplásica e, portanto, que o paciente não está adequadamente tratado. ${ }^{56}$ No seguimento pósoperatório, níveis de CT basal dentro dos limites da normalidade devem ser sempre confirmados com testes provocativos. ${ }^{8,56}$ Portadores de mutação no RET, cujas dosagens séricas de CT basal estão nos limites da normalidade, fatalmente terão o teste convertido em alguma fase de sua vida.

Cura bioquímica, equivalente à cura operatória, é determinada quando o paciente é submetido a testes de estímulo para CT e estes são negativos. Elevações nas dosagens séricas de CT, até seis meses da operação, mesmo após sua queda ou normalização, indicam persistência da neoplasia. Elevações após os primeiros seis meses de sua normalização pós-operatória indicam recidiva do tumor. ${ }^{34}$ Calcitonemia, por sua vez, pode permanecer elevada por anos sem que indícios clínicos ou em exame de imagem indiquem o local da recidiva ou persistência neoplásica. ${ }^{57}$ Taxas específicas de CT após estímulo que definem cura ou doença presente e seus métodos de dosagem também não são padronizados. ${ }^{34}$

Valores pré-operatórios elevados foram relacionados com estádios tumorais mais avançados. ${ }^{1,13,56}$ Cohen et al. ${ }^{13}$ observaram que níveis pré-operatórios de CT correlacionaram-se com diâmetros neoplásicos, especialmente em casos familiares, e que estes níveis, juntamente com diâmetros tumorais, são significativamente maiores 
em pacientes não curados. Correlacionaram também determinado nível de CT préoperatória (acima de 1000 pg/mL) com a existência de doença metastática a distância e de cura após tratamento cirúrgico (títulos de CT menores que 50 pg/mL). Entretanto, a dosagem pré-operatória aumentada de CT não implicou ausência de cura após o tratamento. Idade, gênero e formas clínicas não foram preditivos de normalização pós-operatória de CT. Referências para CT basal e sob estímulo foram estabelecidas, para este estudo, em valores menores que $10 \mathrm{pg} / \mathrm{mL}$.

Sheuba et al. ${ }^{58}$ puderam diferenciar casos de HCC sem desenvolvimento neoplásico de portadores de CMT, através de testes de estímulo em 86 pacientes, mas não encontraram correlação entre níveis de CT basal e sob estímulo e presença de CMT com ou sem metástases a distância. Níveis basais de CT mostraram-se úteis como critérios de diferenciação entre pacientes com metástases linfonodais e aqueles sem doença metastática cervical.

Em estudo com 15 pacientes, portadores assintomáticos de NEM2A e submetidos à tireoidectomia, Hotz et al. ${ }^{59}$ puderam correlacionar níveis de CT basal com achados de HCC e microcarcinomas. O mesmo não foi possível com a utilização das medidas de CT sob estímulo.

Como células do sistema "APUD", as células "C" também secretam outras substâncias. Neoplasias originárias destas células podem produzir elementos não produzidos normalmente por suas equivalentes não-patológicas, de tal forma que outros hormônios polipeptídeos como ACTH ("adrenocorticotropic hormone" ou hormônio adrenocorticotrópico), endorfinas e somatostatina, além de aminas bioativas e enzimas (dopamina, dopadescarboxilase, histaminase e serotonina) entre 
outras substâncias (antígeno carcinoembrionário, melanina, fator de crescimento neural e prostaglandinas, por exemplo) podem ser secretados pelo CMT. ${ }^{8}$

O antígeno carcinoembrionário (CEA ou “carcinoembryonary antigen”) pode ser útil como marcador do CMT, menos específico e sensível, porém, que a CT, ao elevar-se em diversas situações clínicas. ${ }^{60}$ No seguimento do CMT pode ser usado em conjunto com a CT, mas não em sua substituição. ${ }^{1}$ Estudos demonstraram que CEA é marcador mais sensível que CT no diagnóstico de recorrência e de metástases. ${ }^{60}$ Sua meia vida é bem mais longa que da CT e seus títulos podem manter-se elevados por meses, mesmo após tratamento cirúrgico bem sucedido. ${ }^{56}$

Alguns dos imunomarcadores das células "C" relacionam-se com sua natureza neuroendócrina, como enolase neurônio-específica, sinaptofisina e cromograninas e, outros, com os produtos celulares citados acima. Os marcadores mais específicos, porém, são a própria CT e o peptídeo geneticamente relacionado à CT (CGRP ou "calcitonin gene-related peptide"). CEA também é um bom marcador, particularmente se as células " $\mathrm{C}$ ” forem hiperplásicas ou neoplásicas. Estas, quando hiperplásicas, também são coradas pela cromogranina. Os valores diagnósticos destes estudos são imensos, especialmente no diagnóstico diferencial com outras entidades neoplásicas. ${ }^{61}$

Coloração imuno-histoquímica para CT é positiva em aproximadamente $80 \%$ dos CMTs, embora possam existir consideráveis variações na intensidade de coloração em diferentes áreas de um mesmo tumor. Já foi demonstrado que o CMT pode ter sua capacidade reduzida de sintetizar e secretar CT, conotando doença mais agressiva, ${ }^{53}$ em direção à desdiferenciação. Da mesma forma, redução de seus títulos 
séricos em paciente com doença ativa não significa cura, mas redução da capacidade neoplásica de produzir CT. ${ }^{1}$

\subsubsection{APRESENTAÇÕES CLÍNICAS E RELAÇÕES GENÓTIPO- FENÓTIPO}

O CMT apresenta-se sob diferentes formas clínicas e com características próprias bastante peculiares. A maioria dos casos é esporádica (CMT-E), não herdada geneticamente e, por definição, não apresenta mutações germinativas no RET proto-oncogene, embora estas possam ser somáticas. Seguem os casos familiares, de transmissão autossômica dominante vinculada a mutações germinativas, passíveis de detecção em códons do RET proto-oncogene. O CMT pode ser manifestação única entre membros da família acometida (CMTF-I) ou vir acompanhado de outras endocrinopatias. As síndromes das NEM2s têm, no mínimo, três variantes clínicas que compartilham da proliferação anormal das células "C" como manifestação comum. Cada variante das NEM2s resulta de mutações em códons específicos do RET proto-oncogene. Já, a síndrome das NEM1s pode vir acompanhada de mais de 20 tumores endócrinos ou neuroendócrinos diferentes, mas entre eles não se observa o CMT. ${ }^{43}$

O CMT-E manifesta-se comumente em indivíduos a partir da quarta década de vida através, com freqüência, da presença de massa cervical. ${ }^{35}$ Em estudo ${ }^{1}$ com 161 pacientes, foi observado que, em 93,6\% dos casos esporádicos, a principal 
manifestação clínica inicial havia sido a presença de nódulo tireóideo. Cinqüenta e dois por cento dos pacientes já apresentavam linfadenopatia cervical metastática, 13,6\% sintomas compressivos locais e, 12\%, metástases a distância. Diarréia foi relatada por $28,8 \%$ dos pacientes esporádicos estudados, como decorrente de substâncias humorais secretadas pelo tumor e sinal de mau prognóstico a longo prazo. $^{1}$

Lesões esporádicas tendem a ser tumores unifocais. Hundahl et al. ${ }^{2}$ encontraram 20,6\% de multicentricidade neoplásica entre casos esporádicos, contra $50 \%$ entre os familiares. Miyauchi et al., ${ }^{62}$ entre 60 espécimes neoplásicos esporádicos, observaram 11 com multicentricidade, ipsilaterais ao tumor principal, que denominaram metástases intraglandulares. Afirmaram que a disseminação neoplásica intratireóidea estaria associada à extensa disseminação metastática linfonodal cervical. Todos os pacientes com multicentricidade neoplásica apresentavam metástases linfonodais cervicais, contra 44\% dos demais.

Todas as variantes das NEM2s têm alta penetrância para o CMT, neoplasia observada, com freqüência, como primeira manifestação das síndromes e com grande possibilidade de desenvolver-se em algum estágio da vida de seus portadores. ${ }^{43}$

Na NEM2A, o CMT tende a manifestar-se na terceira década de vida, embora os programas de rastreamento familiar tenham proporcionado diagnósticos em indivíduos cada vez mais jovens, antes mesmo do desenvolvimento neoplásico. Multicentricidade e bilateralidade são muito freqüentes. Bilateralidade foi observada em $75 \%$ dos casos, entre 60 portadores de neoplasias macroscópicas. ${ }^{62}$

Feocromocitoma e hiperparatireoidismo completam a síndrome. Geralmente manifestam-se após o CMT e com penetrância menor. Entre os acometidos pela 
NEM2A, Saad et al. ${ }^{1}$ contabilizaram $48,4 \%$ de pacientes com feocromocitoma ( $87,5 \%$ bilaterais) e 22,6\% com HPT. Feocromocitoma é precedido por hiperplasia da medular adrenal e sintomas associados, como aumento de pressão arterial, taquicardia, nervosismo e cefaléia, além de sintomas relacionados à hipercalcemia, devem sempre ser investigados. ${ }^{35}$ Outras referências também estimaram o desenvolvimento de feocromocitoma, unilateral ou bilateral, em cerca de $50 \%$ dos acometidos e, o desenvolvimento de HPT, em $20 \%$ a $30 \% .{ }^{43} \mathrm{Na}$ NEM2A, a maioria dos pacientes em vigência de HPT não apresenta sintomas clínicos ou indícios bioquímicos de hipercalcemia, de tal forma que sua ocorrência é muito distinta entre os relatos de diferentes pesquisadores, a depender dos critérios utilizados para diagnóstico. ${ }^{1}$ Hiperparatireoidismo pode decorrer tanto da hiperplasia como do adenoma das paratireóides, embora a primeira situação seja mais prevalente.

Existe variação da NEM2A caracterizada pela associação de líquen cutâneo de amiloidose, caracterizado pela presença de lesões pruriginosas principalmente em porção superior do dorso. $^{8,43}$

Szinnai et al. ${ }^{48}$ reviram 256 casos pediátricos portadores de NEM2A e apresentados em 47 estudos publicados entre 1982 e 2002, sendo quatro casos próprios. O mais jovem paciente em que o CMT foi diagnosticado tinha um ano de idade e apresentava mutação no códon 634 do RET. Observaram que portadores de mutação no códon 634, contra portadores de mutações nos códons 618 e 620, apresentavam risco significativamente maior de desenvolvimento de CMT e CMT metastático, sendo tal risco idade-dependente. Feocromocitoma foi observado em 1,9\% dos pacientes e HPT em 5,5\%, sendo todos portadores de mutações no códon 634 e com mais de 10 anos de idade. 
A NEM2B é menos prevalente, porém associada à forma mais agressiva de CMT. Com freqüência, a neoplasia é diagnosticada em indivíduos bastante jovens, na primeira infância inclusive. Ao diagnóstico, doença metastática regional pode ser observada em cerca de $80 \%$ dos pacientes e, metástases a distância, em até $20 \%$. ${ }^{35}$ Os pacientes também podem apresentar feocromocitomas ( $40 \%$ a $50 \%$ dos casos) e ganglioneuromatose difusa do trato gastrointestinal. Neuromas mucosos e alterações esqueléticas, que incluem hábito marfanóide, ocorrem em praticamente todos os acometidos. ${ }^{63}$ Podem ser observados neuromas conjuntivais, fibrose corneal e conjuntivite "sicca", também idade-dependentes. ${ }^{32}$ Obstipação intestinal é freqüente na primeira infância, seguida de diarréia no decorrer dos anos. ${ }^{64}$ Já, o desenvolvimento de HPT é bastante raro. História familiar muitas vezes é negativa, pois muitos dos doentes acometidos portam mutações novas no RET proto-oncogene. Morbidade é mais severa que na NEM2A e, mortalidade, precoce. $^{43}$

Modigliani et al. ${ }^{9}$ estudaram 899 pacientes. A forma esporádica representou $57,3 \%$ da amostra e as formas familiares 42,7\% (29,7\% NEM2A; 10,8\% CMTF-I e 2,2\% NEM2B). Enquanto feocromocitoma foi diagnosticado em 53,3\% dos pacientes portadores de NEM2A e em 45\% dos portadores de NEM2B, HPT foi diagnosticado em $23,6 \%$ dos portadores de NEM2A.

Brauckhoff et al. ${ }^{64}$ estudaram 21 pacientes de famílias distintas, portadores de NEM2B por mutação germinativa no códon 918. Oitenta e seis por cento dos pacientes apresentavam tumores multifocais, 67\% tumores localmente avançados e $86 \%$ metástases linfonodais cervicais. Trinta e três por cento dos pacientes faleceram por metástases a distância, entre sete e 145 meses do tratamento inicial. Independente do diagnóstico de NEM2B decorrer do CMT sintomático ou de outros sintomas 
relacionados à síndrome, o carcinoma tireóideo foi diagnosticado em estádios avançados na maioria dos casos.

A forma isolada do CMT familiar (CMTF-I), também é herdada de maneira autossômica dominante, não devem existir outras neoplasias endócrinas associadas e corresponde à apresentação clínica mais indolente do CMT. ${ }^{35}$ A doença apresenta-se em indivíduos mais velhos em relação ao seu período de manifestação nas NEM2s.

Dralle et al. ${ }^{47}$ estudaram 75 casos de crianças e adolescentes portadores de mutações no RET proto-oncogene e submetidos à tireoidectomia pré-sintomática. Foram observados dois casos de feocromocitoma, mas nenhum de HPT, embora tenha sido observado certo grau de hiperplasia de paratireóides em três pacientes, entre 34 submetidos à análise histológica das mesmas. Em 61\% dos pacientes foram encontrados focos de CMTs, principalmente bilaterais, e, em todos os demais, HCC estava presente, freqüentemente bilateral também, indicando que a transformação maligna de células "C" já havia começado. O aumento da idade dos pacientes relacionou-se com maior comprometimento de células "C". Todos os pacientes com mais de 10 anos de idade apresentavam, no mínimo, HCC bilateral, embora uma criança de quatro anos já apresentasse CMT. Três pacientes tiveram evidências histológicas de metástases linfonodais cervicais. Suas idades eram 14, 15 e 19 anos. Tais observações confirmaram a dependência da idade na penetrância das alterações genéticas e desenvolvimento dos fenótipos correspondentes.

Em estudo conduzido por Kebebew et al., ${ }^{10}$ pacientes com CMT-E eram mais velhos (média de 47,3 anos) que aqueles portadores de tumores familiares (média de 25,2 anos para os NEM2As, 19,9 anos para os NEM2Bs e 29,1 anos para os CMTF-Is), diferença estatisticamente significativa e persistente, mesmo após 
exclusão dos indivíduos diagnosticados por rastreamento. Oitenta e cinco por cento dos tumores familiares eram bilaterais, contra $66,7 \%$ entre os esporádicos.

As proporções entre CMT-E e formas familiares, e as próprias formas familiares entre si, podem ser variáveis nos diferentes estudos e dependem dos critérios diagnósticos utilizados, do rastreamento genético e do tamanho das famílias acometidas, como também da adesão de seus componentes aos programas de rastreamento. Maior freqüência de casos hereditários é observada em relatos mais recentes, justamente em função da disponibilidade comercial de "kits" laboratoriais para rastreamento genético. Assim, idades ao diagnóstico também são variáveis. Observa-se que, nos casos familiares, o diagnóstico tem sido realizado em indivíduos cada vez mais jovens e com maior ênfase ao diagnóstico genético. ${ }^{17}$

Casos familiares podem ser inadequadamente classificados como esporádicos em função de histórias familiares pouco precisas, assim como o paciente pode ser caso "index" ou portador de mutação nova. Famílias pequenas, portadoras de NEM2A, em que a única manifestação no momento do diagnóstico é o CMT, podem ser inadequadamente classificadas como famílias de CMTF-Is e o risco de desenvolvimento de feocromocitoma e HPT ser ignorado. ${ }^{43}$ Deve-se ficar atento ao fato de que análises negativas para alterações no RET não devem excluir completamente a possibilidade de mutação germinativa, especialmente em pacientes jovens, portadores de CMTs multifocais e de HCC, uma vez que a mutação pode estar presente em éxon não pesquisado. ${ }^{65}$

São observadas variações na penetrância da doença, idade à manifestação e quadro clínico de portadores de mesma mutação em mesmo códon, justificadas pela 
presença de outras mutações germinativas associadas, não necessariamente diagnosticadas, ou mutações somáticas adicionais, também não diagnosticadas. ${ }^{65}$

Gimm et al. ${ }^{66}$ estudaram 140 pacientes com CMTF-Is ou vinculados à NEM2A e não relacionados à mutação no códon 634, mais prevalente e mais estudada. Nos pacientes com mutações nos códons 618, 620 e 891, o CMT desenvolveu-se em idades mais precoces. CMT foi observado em pacientes a partir dos 29 anos entre os acometidos por mutações no códon 768. Entre portadores de mutações nos códons 611, 790, 791 e 804, a neoplasia foi diagnosticada em indivíduos mais velhos, entre 33 anos (códon 804) e 60 anos (códon 611), com a exceção de único indivíduo que já apresentava a neoplasia aos 13 anos de idade (códon 790). As maiores variações entre idades e fenótipos ocorreram nos portadores de mutações no códon 804. Doença metastática, porém, foi encontrada, com maior freqüência, entre pacientes com tumores multifocais. Portadores de mutações nos códons 620, 768, 791 e 804 desenvolveram metástases linfonodais somente na presença de tumores primários maiores ou iguais a $1 \mathrm{~cm}$ em seu maior diâmetro. Nenhum paciente com mutações nos códons 791 ou 804 apresentou metástases a distância e, todos que o fizeram entre os indivíduos estudados, tinham no mínimo 40 anos de idade e tumores primários maiores ou iguais a $1 \mathrm{~cm}$.

Tisell et al. ${ }^{67}$ identificaram metástases linfonodais cervicais em $90 \%$ dos pacientes com CMT primário palpável. Nos portadores de CMT hereditário, já palpável ao exame físico, as metástases linfonodais distribuíam-se bilateralmente na região cervical em $88 \%$ dos acometidos. Na ausência de tumores primários palpáveis, $27 \%$ dos portadores de CMT-F apresentavam metástases cervicais. 
As metástases linfonodais cervicais podem desenvolver-se nos compartimentos central e lateral. O primeiro inclui os níveis linfonodais VI, peritireóideo e paratraqueal, e VII, mediastinal superior. É delimitado lateralmente pelas bainhas júgulo-carotídeas, superiormente pelo osso hióide, inferiormente pela veia inominada e dorsalmente pela fáscia pré-vertebral. Seu envolvimento é, comumente, bilateral. Os compartimentos laterais incluem a área entre as bainhas júgulo-carotídeas, músculos esternocleidomastóideos e músculos trapézios. Seus limites inferiores correspondem às veias subclávias e seus limites superiores aos nervos hipoglossos. São classificados como níveis linfonodais II (júgulo-carotídeos superiores), III (júgulo-carotídeos médios), IV (júgulo-carotídeos inferiores) e V (triângulo cervical posterior). ${ }^{68}$

Em estudo com 73 pacientes, Moley e DeBenedetti ${ }^{68}$ observaram que, independentemente das dimensões do tumor primário, incidências de metástases no compartimento central e nos compartimentos laterais, ipsilaterais e contralaterais, são freqüentes. De 32 pacientes com tumores primários unilaterais, 81\% apresentaram metástases em linfonodos do compartimento central e $81 \%$ em linfonodos laterais ipsilaterais. Quarenta e um por cento tinham metástases contralaterais. Tal proporção foi de $49 \%$ entre pacientes com tumores bilaterais. Dos 41 pacientes com tumores primários bilaterais, $78 \%$ tinham metástases centrais e $71 \%$ laterais ipsilaterais ao tumor de maior diâmetro. Observaram também que a palpação intra-operatória dos linfonodos, mesmo por "mãos experientes", não é método acurado de previsão do acometimento metastático linfonodal.

Tavares, em trabalho retrospectivo, ${ }^{69}$ notou que de 88 indivíduos portadores de CMT, $40(45,5 \%)$ o eram da forma esporádica, 36 (40,9\%) vinculados à NEM2A, 
$12(13,6 \%)$ CMTF-I e nenhum vinculado à NEM2B. De 32 pacientes incluídos no estudo, multicentricidade neoplásica foi encontrada em 72,2\% dos casos familiares e em 28,6\% dos casos esporádicos (diferença estatisticamente significativa). HCC foi constatada em $83,3 \%$ dos casos familiares e em 16,7\% dos esporádicos (diferença também estatisticamente significativa). Metástases cervicais foram observadas em 20 pacientes, sem diferenças estatisticamente significativas entre as formas esporádica e familiar. Treze apresentaram comprometimento do compartimento central, correspondendo a $40,6 \%$ do total de casos analisados e $65 \%$ dos casos com metástases cervicais. Os compartimentos laterais estavam afetados em 14 pacientes, correspondendo a $43,8 \%$ do total de casos e $70 \%$ dos casos com metástases cervicais. Concluiu que os níveis VI e VII cervicais comportam-se como única estação de drenagem, ou seja, a presença de metástase no nível VI pode corresponder à presença de metástase no nível VII e o mesmo vale para a ausência de lesões. Ausência de metástases centrais não foi preditiva de ausência de metástases laterais e o mesmo vale para sua presença.

Os sítios mais comuns de metástases a distância são mediastino, pulmões, ossos, sistema nervoso central e fígado. Podem ocorrer independentemente das dimensões do tumor primário. Em série ${ }^{70}$ de 80 pacientes operados consecutivamente por CMTs, 10 já apresentavam metástases a distância (fígado, pulmões, ossos e linfonodos não-cervicais) em sua admissão ao serviço. Em outro estudo ${ }^{10}$ que incluiu 104 pacientes portadores de CMTs, foi observado que todos aqueles pacientes esporádicos apresentando sintomas sistêmicos (diarréia, dores ósseas ou rubor facial) já eram portadores de metástases a distância, à sua admissão. 


\subsubsection{ESTADIAMENTO}

O sistema de estadiamento mais utilizado é o sistema TNM, proposto pela “Union Internacionale Contre le Cancer" (União Internacional contra o Câncer UICC) e pela "American Joint Committee on Cancer" (Comitê Americano para o Câncer - AJCC). É considerado o maior diâmetro neoplásico (“T” ou "tumour"), presença de metástases linfonodais cervicais ("N" ou "nodes") e presença de metástases a distância ("M" ou "metastases"). A última edição do Manual de Estadiamento do Câncer da AJCC data de $2002^{71}$ e os dados relativos ao CMT encontram-se no ANEXO A. A maioria dos artigos pesquisados para este trabalho utilizou sistemas TNM de edições mais antigas. A edição, anterior à apresentada, data de 1997 (quinta edição), ${ }^{72}$ e utiliza sistema classificatório um pouco diferente.

Outros sistemas de estadiamento incluem o sistema da "European Organization for Research and Treatment of Cancer" (EORTC), que atribui pontos a características clinicopatológicas como gênero e tipo histológico; o sistema do "National Thyroid Cancer Treatment Cooperative Study" (NTCTCS) e o sistema do "Surveillance, Epidemiology, and End Results Program" (SEER), que considera a extensão da doença classificando-a como local, regional ou metastática. Segundo Kebebew et al., ${ }^{10}$ todos esses sistemas de estadiamento citados são preditivos acurados de sobrevida para portadores de CMT. 


\subsubsection{MÉTODOS DIAGNÓSTICOS}

O diagnóstico precoce é o grande objetivo para o CMT, do qual se pode resultar procedimento cirúrgico inicial imediato e adequado, principalmente no que se diz respeito ao tratamento das cadeias linfonodais cervicais, permitindo maiores taxas de cura bioquímica e melhor prognóstico.

Sintomas loco-regionais e sistêmicos podem orientar o diagnóstico de neoplasia tireóidea, como também do próprio CMT, principalmente se pertencer às síndromes das NEMs. Em muitos casos, porém, o diagnóstico do CMT, principalmente quando esporádico, é feito no pós-operatório, após análise histológica e, muitas vezes, imuno-histoquímica da peça operatória.

Dosagem rotineira de CT sérica nos pacientes em investigação de nódulos tireóideos é advogada por alguns autores. ${ }^{4,73,74}$ Pacini et al. ${ }^{4}$ diagnosticaram, entre 1385 portadores de doença nodular tireóidea, oito casos $(0,57 \%)$ de CMT através de dosagens pré-operatórias de $\mathrm{CT}$, o que proporcionou pronta e adequada terapia cirúrgica. A CT sérica mostrou-se superior à punção aspirativa com agulha fina (PAAF) do nódulo tireóideo na sugestão do diagnóstico de CMT. Não relataram casos falso-positivos. Henry et al. ${ }^{73}$ observaram prevalência de $0,71 \%$ de CMT entre portadores de nódulos tireóideos e, Elisei et al., ${ }^{74} 0,4 \%$ entre 10864 portadores de nódulos tireóideos. Neste último estudo, positividade para CT sérica também apresentou sensibilidade e especificidade diagnósticas maiores que a PAAF. Os custos iniciais das dosagens de CT sérica devem compensar os custos hospitalares e 
sociais de pacientes cujos diagnósticos de CMT são tardios, com óbvio comprometimento de seus prognósticos.

$\mathrm{O}$ aumento de $\mathrm{CT}$ sérica não é exclusivo do $\mathrm{CMT}$, embora ensaios imunorradiométricos tenham reduzido tal artefato. Em outras situações clínicas, que não o CMT, testes de estímulo para CT tendem a ser negativos. Nos casos de CMTs subclínicos, nenhum outro procedimento tem permitido seu diagnóstico de modo tão acurado como a dosagem de CT, principalmente se se tratar de microcarcinoma, quando ultra-sonografia (USG), PAAF e cintilografia são inadequadas para sua detecção. $^{73}$

Dosagem de CT pode encontrar-se sob níveis elevados em casos de HCC sem evidências histológicas de CMT. Como a HCC é considerada condição préneoplásica para a neoplasia, indicação cirúrgica com base em resultado alterado desta dosagem parece ser pertinente. ${ }^{13}$ A dosagem de CEA é recomendada no préoperatório e deve ser utilizada comparativamente no seguimento pós-cirúrgico, juntamente com dosagens de CT.

Métodos de imagem como USG, tomografia computadorizada e ressonância nuclear magnética podem auxiliar o diagnóstico do tumor primário, bem como auxiliar o estadiamento clínico do paciente.

Nos preparados citológicos, o CMT tende a ser pleomórfico. Depósitos de amilóide podem eventualmente ser observados em produtos de PAAF, orientando o diagnóstico. Este, no entanto, muitas vezes depende de colorações IH (CT, CEA e cromogranina, principalmente) que poderão proporcionar o diagnóstico diferencial com outras entidades como tumores foliculares, anaplásicos e até metastáticos. ${ }^{53}$ 
À suspeita de NEM, feocromocitoma e HPT, que podem ser assintomáticos, devem ser pesquisados.

\subsubsection{RASTREAMENTOS FAMILIAR, BIOQUÍMICO E GENÉTICO}

O indício de outros casos de CMT em familiares de um paciente, assim como associação de feocromocitoma, HPT, características físicas conformacionais sindrômicas e características histológicas da tireóide, como presença de áreas de HCC e CMT multifocal, podem sugerir o diagnóstico de doença hereditária. Preconiza-se estudo genealógico pormenorizado, nem sempre possível, e, muitas vezes, pouco sensível. História familiar negativa, por sua vez, não afasta a possibilidade de doença familiar, considerando-se que o paciente em questão pode tratar-se de caso "index" ou ser portador de nova mutação. Em condições ideais, todos os pacientes com diagnóstico de CMT devem ser submetidos ao teste genético específico para detecção de mutações no RET. ${ }^{8}$

O rastreamento bioquímico refere-se à dosagem de CT basal e sob estímulo de todos os descendentes diretos do indivíduo afetado pelo CMT. Os testes devem ser realizados a partir dos cinco anos de idade e, se mantidos dentro dos limites da normalidade, repetidos anualmente até os 35 ou 40 anos, limite habitual para que os portadores de mutação no RET proto-oncogene convertam o exame. Efeitos colaterais como náusea e desconforto abdominal podem ocorrer durante a realização do teste de estímulo, há a possibilidade de resultados falso-positivos (5\% a 10\% dos 
casos) e há dificuldade de se interpretar testes de estímulo com resultados limítrofes. ${ }^{35,75}$ A detecção de níveis alterados deste marcador é indício confiável da progressão da neoplasia em indivíduos portadores da mutação no RET e indica tratamento cirúrgico imediato. ${ }^{76}$ Alguns autores preconizam o início dos testes de estímulo para familiares ainda mais jovens, a partir do primeiro ano de vida. ${ }^{48}$

$\mathrm{Na}$ sua disponibilidade, todos os pacientes portadores de CMT, seja este hereditário ou aparentemente esporádico, devem ser submetidos ao seqüenciamento genético para detecção de possível mutação germinativa no RET proto-oncogene. A análise é realizada em amostra de sangue periférico. Ao ser identificada a mutação, todos os familiares de primeiro grau do paciente devem ser submetidos, o quanto antes, ao mesmo rastreamento genético. Identificados os portadores de mutação no RET, sabe-se quem são os familiares com risco de desenvolvimento do CMT e o tratamento é proposto. A conduta para cada família então é variável, em função do códon afetado pela mutação. Membros sem mutações no RET têm o mesmo risco que a população geral para desenvolvimento do CMT e não serão mais necessários testes de rastreamento para estes ou seus filhos. ${ }^{75}$ Segundo o Consenso para Diagnóstico e Terapia das NEMs de $2001,{ }^{43}$ a pesquisa genética deve iniciar-se rotineiramente pelos éxons $10,11,13,14,15$ e 16 do RET. Na ausência de mutações nos códons destes éxons, parte-se para a pesquisa nos 15 éxons restantes. Se o teste ainda for negativo em caso "index" de uma família, presume-se que se trata de caso esporádico ou de portador de alguma alteração genética não diagnosticada. $\mathrm{Na}$ suspeita da forma familiar da doença, mesmo com rastreamento genético negativo, insiste-se no diagnóstico de hereditariedade através de rastreamento bioquímico. A incorreta exclusão de hereditariedade é inaceitável. 


\subsubsection{TRATAMENTO}

O único tratamento eficaz para o carcinoma medular é cirúrgico e seu sucesso é fortemente dependente do estádio clínico do paciente e da adequação da conduta terapêutica inicial. Não existem, até o presente momento, terapias comparáveis. Feito o diagnóstico, o paciente deve ser submetido à tireoidectomia total e às linfadenectomias central e lateral (bilateral), que envolvem os níveis linfonodais VI e VII e II, III e IV, mesmo na ausência clínica de metástases. A ressecção linfonodal deve ser minuciosa, uma vez que terapias adjuvantes não são eficazes.

Randolph e Maniar ${ }^{35}$ afirmaram haver aumento na taxa de cura bioquímica em mais de $20 \%$ quando a linfadenectomia lateral é incluída no plano de tratamento, justificando o esvaziamento cervical eletivo dos compartimentos central e lateral. $\mathrm{Na}$ presença de metástases clinicamente comprovadas, o esvaziamento terapêutico envolve os mesmos compartimentos, devendo-se incluir no produto de ressecção o nível V ipsilateral às metástases cervicais. Os níveis I (submandibulares) encontramse envolvidos em situações excepcionais. Esternotomia para dissecção mediastinal, em pacientes com doença extensa nesta região, pode eventualmente ser indicada. Vários estudos respaldaram a conduta descrita. ${ }^{10,35,58,63,68,69,77}$

Microdissecção sistemática compartimento-orientada dos linfonodos cervicomediastinais foi proposta por Dralle et al. ${ }^{78,79}$ com taxas significativamente maiores de normalização de CT sérica, e, portanto, cura bioquímica, menores taxas de recidiva neoplásica e maiores taxas de sobrevida em relação aos pacientes submetidos ao esvaziamento habitual. Yen et al. ${ }^{70}$ observaram minimização na taxa 
de recidiva neoplásica nos pacientes submetidos a este tipo de linfadenectomia, mesmo entre aqueles já recorrentes.

A grande realização no manejo do CMT-F é o tratamento dos portadores de mutação no RET proto-oncogene antes que a neoplasia manifeste-se clínica ou bioquimicamente, ou seja, antes que haja progressão de HCC para carcinoma. Este é o grande diferencial em relação ao tratamento de outras neoplasias malignas. É o tratamento denominado profilático pela maioria das publicações, que preferimos denominar pré-sintomático. Sabe-se que qualquer extensão extratireóidea da doença compromete, quando não impede, a cura do paciente e que a possibilidade de operação limitada à glândula tireóide reduz os riscos de complicações como hipoparatireoidismo e comprometimento dos nervos laríngeos recorrentes.

Alguns definem a tireoidectomia profilática como sendo realizada em portadores de mutações no RET, com menos que 20 anos de idade, assintomáticos, portadores de tumores com menos de $1 \mathrm{~cm}$ e sem metástases a distância. É ainda impossível, porém, predizer, com exatidão, quais os portadores de mutações no RET desenvolverão CMT e em que idade. ${ }^{47}$

Dralle et al. ${ }^{47}$ observaram que todos os 75 casos operados profilaticamente apresentavam, no mínimo, HCC. Sessenta e um por cento dos pacientes já apresentavam focos de CMT, dado que torna justificável a indicação de tireoidectomia, no mínimo, baseada em evidências de mutações no RET. Propuseram que o procedimento seja realizado ao redor dos seis anos de idade, quando a doença, se existente, deverá estar ainda restrita aos domínios da glândula. Notaram também que o risco de linfadenomegalia metastática eleva-se com a idade, embora raramente ocorra em crianças com menos de 10 anos de idade e esteja relacionado a aumento 
nos níveis séricos de CT basal ou sob estímulo. Recomendaram que a tireoidectomia total pré-sintomática, sem linfadenectomia, seja realizada até os 10 anos de idade em crianças portadoras de mutação no RET, com níveis de CT sob estímulo dentro dos limites da normalidade. Se os níveis de CT estiverem aumentados ou o indivíduo tiver mais que 10 anos de idade, linfadenectomia estará indicada. Sugeriram o esvaziamento dos compartimentos central e laterais do pescoço se o indivíduo, com níveis elevados de CT, tiver mais que 15 anos de idade ou já existirem evidências clínicas de doença linfonodal.

Scheuba et al. ${ }^{59}$ valorizaram os níveis de CT na determinação da conduta cirúrgica e basearam-se em sua experiência relatada em estudo de 86 pacientes. Ao considerarem como valores normais para a $\mathrm{CT}$ basal resultados menores que 10 $\mathrm{pg} / \mathrm{mL}$ e, para a estimulada, menores que $100 \mathrm{pg} / \mathrm{mL}$, determinaram que pacientes com níveis de CT basal entre 10 e 64 pg/mL e sob estímulo entre 129 e 560 pg/mL deveriam ser submetidos às tireoidectomia total e linfadenectomia do compartimento central. Pacientes com tumores maiores que $3 \mathrm{~mm}$ deveriam também ser submetidos à linfadenectomia dos compartimentos cervicais laterais. Já, pacientes com tumores menores que $3 \mathrm{~mm}$ deveriam sofrer o esvaziamento lateral, a depender dos valores de CT basal e sob estímulo. Nos indivíduos com CT basal maior que $64 \mathrm{pg} / \mathrm{mL}, \mathrm{CT}$ sob estímulo maior do que $560 \mathrm{pg} / \mathrm{mL}$, ou ambos, a presença de CMT é pressuposta e a tireoidectomia total deve ser acompanhada das linfadenectomias central e laterais. Os níveis de CT basal e sob estímulo foram significativamente diferentes entre portadores de HCC e CMT e entre aqueles com e sem metástases linfonodais.

Kebebew et al. ${ }^{10}$ preconizaram a tireoidectomia pré-sintomática ao redor dos seis anos de idade, mas só indicam o esvaziamento do compartimento central se 
calcitonemia estiver elevada, se houver lesão macroscópica tireóidea ou se algum linfonodo desta região apresentar aspectos patológicos. No diagnóstico de NEM2B, tireoidectomia deve ser realizada imediatamente.

Por outro estudo, ${ }^{48}$ concluiu-se que a idade ideal para o tratamento operatório dos portadores de mutação no RET é entre os dois e cinco anos de idade, embora relate caso de CMT em portador de mutação no códon 634 de um ano de idade. $\mathrm{Na}$ alteração dos níveis de CT dosados anualmente, tireoidectomia deve ser realizada independentemente da idade da criança. Tal conduta reduziu significativamente as taxas de CMT e CMT metastático, com reflexo nas evoluções dos pacientes.

Machens et al. ${ }^{46}$ afirmaram ser mais sensato, para a determinação da melhor época para o tratamento cirúrgico de portadores de genótipos específicos, considerar a menor idade em que o fenótipo neoplásico já se manifestou. Pelo seu estudo, portadores de mutações no códon 918 devem ser tratados com um ano de idade e, portadores de mutações no códon 634, aos dois anos. Consideraram como seguro que portadores de mutações nos códons 611, 618, 620, 630, 768, 790, 791 e 804 aguardem até os cinco anos de idade para a operação. Observaram que em pacientes portadores de mutações no RET, outras que não nos códons 634 e 918, o desenvolvimento de metástases linfonodais cervicais e a distância é rara antes dos 20 anos de idade.

Em função de seu genótipo, os pacientes podem ser agrupados em categorias de risco. Crianças portadoras de mutações nos códons 883, 918 ou 922 (NEM2B) são classificadas como "nível 3" e têm o maior risco para desenvolvimento de CMTs agressivos. Tireoidectomia com linfadenectomia central deve ser realizada até os seis meses de vida, preferencialmente a um mês do nascimento. Na presença de 
linfadenomegalia metastática, o esvaziamento cervical é ampliado para os compartimentos laterais. O "nível 2" inclui portadores de mutações nos códons 611, 618, 620 e 634 (NEM2A e CMTF-I), com alto risco de desenvolvimento de CMT, e o tratamento cirúrgico deve acontecer até os cinco anos de idade. Nestes casos, não há consenso quanto à indicação de linfadenectomia na ausência de metástases aparentes ou alterações nos níveis de CT. Portadores de mutações nos códons 609, 768, 790, 791, 804 e 891 (CMTF-I) são classificados como "nível 1" e têm o menor risco de desenvolvimento de CMT, entre os portadores de mutações germinativas no RET. O tratamento cirúrgico também está indicado para estes pacientes, são diversas, porém, as opiniões quanto às idades ideais para tal. ${ }^{43}$

Aspectos em relação à conduta terapêutica baseada no genótipo devem ser ressaltados. A experiência clínica com portadores de mutações em códons raramente afetados é pequena, e estes podem relacionar-se com expressividade e penetrância variáveis. Eventos somáticos imprevisíveis podem alterar o curso clínico esperado para a progressão neoplásica em portadores de mutações germinativas, como também a coexistência de outras mutações no RET, germinativas ou somáticas, pode alterar o curso clínico previsto. ${ }^{46}$

Radioterapia e quimioterapia não são eficazes no tratamento do CMT. Indicase radioterapia externa quando a presença de tumor macroscópico permanece após operação ou este é irressecável. ${ }^{10}$ Apesar do emprego de radioterapia ser controverso, alguns autores associaram sua aplicação a evidências de melhora do controle loco-regional da doença em pacientes com tumores avançados. ${ }^{70}$ Hyer et al. 
11 não encontraram diferença na sobrevida geral após emprego de radioterapia, embora recorrência local tenha sido significativamente reduzida com o tratamento naqueles pacientes com doença linfonodal unilateral. $\mathrm{O}$ uso de quimioterapia em pacientes com doença metastática não proporcionou melhora na taxa de sobrevida e nenhum dos seis pacientes tratados apresentou resposta objetiva. Ezabella ${ }^{8} \mathrm{e}$ Modigliani et al. ${ }^{9}$ também não observaram bons resultados com o emprego destas duas modalidades terapêuticas adjuvantes. Várias drogas quimioterápicas já foram ou têm sido testadas e linhas de pesquisa têm sido desenvolvidas. ${ }^{80}$

Terapia com radioisótopos pode ser realizada na presença de evidências cintilográficas de captação e biodistribuição do traçador no tecido neoplásico. Para o CMT, porém, os traçadores conhecidos têm pobre sensibilidade diagnóstica e a modalidade terapêutica só é aplicada como adjuvância ou paliação. A maior experiência em terapia com radioisótopos para tumores neuroendócrinos foi obtida com MIBG (metaiodobenzilguanidina). Análogos da somatostatina, como octreotide e lantreotide, e anticorpos anti-CEA marcados com radioatividade também têm sido utilizados como armas terapêuticas complementares. ${ }^{81}$

São propostas linhas terapêuticas inovadoras, muitas em fase de desenvolvimento, como o controle do crescimento neoplásico com inibidores das ciclooxigenases 1 e $2,{ }^{82,83}$ inibidores da tirosino-quinase, ${ }^{84,85}$ inibidores das vias de transdução ativadas pelo RET proto-oncogene, ${ }^{76}$ imunoterapia com células dendríticas autólogas, ${ }^{86}$ imunoterapia com antígenos de carcinoma de testículo, expressos em parte dos CMTs e relacionados à recidiva neoplásica, ${ }^{87}$ entre outros. As propostas atuais visam ao controle da doença metastática e já em estádios 
avançados, quando a terapia cirúrgica não proporciona mais o controle da neoplasia. 76

\subsubsection{SEGUIMENTO PÓS-OPERATÓRIO E COMPORTAMENTO BIOLÓGICO}

O seguimento pós-operatório consensual consiste em dosagens séricas seriadas de CT e CEA a intervalos regulares. CT sob estímulo deve ser colhida após seis semanas da operação e repetida a cada seis meses ou anualmente, por 10 anos. Mantendo-se negativa, o paciente passa a ser submetido a dosagens anuais basais. ${ }^{57}$

Quando a normalização dos títulos de CT sob estímulo é alcançada, o indivíduo está curado. Níveis de CT sob estímulo dentro dos limites da normalidade, porém, não excluem o risco de recidiva. ${ }^{15} \mathrm{Na}$ re-elevação destes títulos, passados mais de seis meses do tratamento cirúrgico e normalização dos níveis séricos do marcador, caracteriza-se a recidiva da neoplasia. No aumento dos níveis de CT ou CEA ou na vigência de sintomas clínicos deve-se indicar a avaliação imagenológica de fígado, pulmões, mediastino, ossos e sistema nervoso central. ${ }^{70}$ Questiona-se se a cura bioquímica realmente acompanha melhor evolução clínica em relação a aqueles pacientes com elevados níveis de CT, mas sem evidências imagenológicas de neoplasia. ${ }^{88}$

Anos podem decorrer do aumento dos títulos de CT para que surjam evidências de metástases nos exames de imagem. ${ }^{57}$ Segundo autores, ${ }^{10}$ praticamente 
todos os pacientes com níveis marcadamente elevados, mesmo após tratamento inicial adequado, têm metástases a distância, mas observaram que 38,3\% dos pacientes estudados apresentavam CMTs persistentes durante seus seguimentos e viveram de um mês a 23,7 anos, apesar de doença presente. Todos concordam, porém, que se trata de neoplasia de evolução letal.

Franc et al. ${ }^{57}$ diagnosticaram recidivas entre 0,2 e 7,5 anos do tratamento inicial $(3,2 \pm 2,2$ anos $)$ e observaram lentas progressões dos níveis de CT sob estímulo. Apenas 1\% dos pacientes desta série de 1430 doentes apresentou recidivas, contra 30,6\% de persistências do tumor após operação. Entre os 15 pacientes com recidivas autênticas, nove haviam sido estadiados como $\mathrm{T} 1$, de tal forma que recorrências poderiam ocorrer independentemente das dimensões do tumor primário, como também em pacientes N0 e submetidos a extensas linfadenectomias cervicais.

Dralle et al., ${ }^{89}$ em estudo com 139 portadores de CMT-F, observaram 52,5\% de cura após tratamento cirúrgico inicial. Nenhum paciente com NEM2B obteve normalização dos níveis de CT após operação, somente $27,1 \%$ daqueles com evidências clínicas de neoplasia foram considerados curados e mais de $60 \%$ daqueles diagnosticados por rastreamento obtiveram cura. As taxas de cura bioquímica entre aqueles não submetidos à linfadenectomia foram significativamente menores, quando comparadas com as dos pacientes submetidos ao procedimento. Porém, linfadenectomia proporcionou cura bioquímica somente nos pacientes estadiados como N0. Nos portadores de tumores primários pequenos, mas já com metástases linfonodais, a linfadenectomia sistemática proporcionou maior redução nos níveis de CT, quando comparada à linfadenectomia seletiva. Vinte pacientes apresentaram metástases a distância comprovadas, dois inicialmente estadiados como N0, e nove 
deles faleceram pela doença no decorrer do seguimento. Certamente, o número de pacientes acometidos por metástases a distância foi subestimado, uma vez que procedimentos de imagem usados de rotina, muitas vezes, não são capazes de diagnosticar tais lesões. Micrometástases a distância podem ser a causa de hipercalcitonemia em pacientes tratados e sem evidências de recidiva local. Recomendaram linfadenectomias sistemáticas dos compartimentos cervicais, mesmo na presença de possíveis micrometástases a distância, para controle local da doença.

Quando o paciente já foi adequadamente tratado com tireoidectomia total e linfadenectomia, a indicação de re-exploração cervical, na elevação dos níveis de CT e ausência de evidências imagenológicas de neoplasia, é muito controversa. Segundo Yen et al., ${ }^{70}$ pacientes já submetidos às tireoidectomia total e linfadenectomia compartimento-orientada dos níveis II a VI do pescoço, mantendo níveis elevados de CT, mas que não ultrapassem $250 \mathrm{pg} / \mathrm{mL}$, devem ser seguidos com exames físicos e dosagens semestrais de CT e CEA e USG cervical anual, até que haja aumento progressivo dos níveis destes marcadores ou surja sintomas clínicos. A doença recidivou em 16 dos 45 pacientes (36\%) estudados, inicialmente M0, entre nove e 125 meses da operação (média de 23 meses). Seis pacientes, originalmente N1, apresentaram recorrências cervicais isoladas e recuperaram os níveis normais de CT após re-operação. Metástases a distância isoladas foram diagnosticadas em sete pacientes e, em associação com recidiva cervical, em três pacientes. Todos eram portadores de tumores avançados iniciais (Estádio IV) e três vieram a falecer pela doença. Os 25 pacientes portadores de CMT-F apresentavam, ao diagnóstico, doenças em estádios mais precoces, sendo que recidiva cervical foi observada em apenas um indivíduo, oito anos após a operação, e metástases ósseas em outro 
paciente, 16 meses após a operação inicial. Ao excluir os três pacientes submetidos ao tratamento pré-sintomático, apenas $22 \%$ obtiveram níveis indetectáveis de CT após operação. Metade deles assim permaneceu até o final do seguimento. Quinze pacientes com níveis elevados de CT, mas sem evidências imagenológicas de recivida neoplásica, foram submetidos à re-exploração cervical, encontrando-se evidências histológicas de neoplasia em $80 \%$ dos casos. Dos 70 pacientes estadiados como M0 à admissão, 16\% evoluíram com metástases a distância. Nove destes 11 pacientes apresentaram aumentos progressivos dos títulos de CT e CEA, com exceção de dois pacientes em quem foram demonstradas imagens radiológicas compatíveis com rápida progressão metastática, mas sem aumento dos níveis de CT e CEA, conotando desdiferenciação neoplásica. Óbito pela doença foi incomum na ausência de evidências imagenológicas de neoplasia.

Gimm et al. ${ }^{88}$ observaram cura bioquímica em $22 \%$ de 37 pacientes portadores de CMT-E, tratados inicialmente com tireoidectomia e esvaziamento cervical não-sistemático, quando submetidos à linfadenectomia dos compartimentos central e lateral (re-operação). Excluindo-se pacientes com metástases distantes, tal taxa elevou-se para $28 \%$. Em apenas um paciente re-operado não foi encontrada evidência histológica de CMT. Após o procedimento inicial, cura bioquímica havia sido obtida em 56\% de 27 pacientes primariamente tratados. Dos pacientes estadiados como T4, 50\% apresentavam metástases para mediastino superior à operação inicial, em contraste com nenhum caso entre aqueles portadores de tumores restritos ao interior da tireóide. Nas recidivas, porém, mesmo aqueles inicialmente estadiados como T1, puderam evoluir com metástases mediastinais. Atribuíram níveis elevados de CT, após a operação inicial, ao acometimento de linfonodos loco- 
regionais residuais, embora a possibilidade de metástases a distância não pudesse ser descartada.

Cohen e Moley ${ }^{63}$ obtiveram normalização das taxas de CT em um terço dos pacientes e, em $40 \%$, redução maior que $35 \%$ após a re-operação cervical por recidiva neoplásica evidente e sem metástases a distância diagnosticadas. Foram estudados 135 pacientes submetidos à dissecção minuciosa dos níveis II a VII. Recomendaram, nestes casos, complementação da investigação de metástases a distância com laparoscopia para exame direto do fígado, à qual atribuíram o diagnóstico de metástases em $20 \%$ a $25 \%$ dos pacientes nos quais exames de imagem falharam em demonstrar tais lesões.

O comportamento biológico do CMT é muito variável. Observam-se casos razoavelmente indolentes em contraste com casos bastante agressivos. ${ }^{6}$ Nota-se também que a evolução a longo prazo pode ser muito satisfatória para pacientes com dosagens séricas de CT elevadas no pós-operatório, sem doenças residual ou metastática demonstráveis clínica ou por exames de imagem, situação não incomum. 9,10, 43,57,63,70,77 Van Heerden et al., ${ }^{90}$ por sua vez, contra-indicaram a re-exploração cervical nestas condições, por considerarem a progressão da doença bastante lenta.

Ezabella ${ }^{8}$ analisou vários métodos para detecção de resquícios tumorais e observou que os mais sensíveis, para localização de recidivas em região cervical, foram USG e PAAF. Para o abdômen, nenhum método mostrou-se eficaz, sendo que nem cintilografias, nem cateterismos venosos seletivos aumentaram a acurácia do diagnóstico. Constatou também que re-operações não induziram os níveis de CT à normalidade, mas notou redução estatisticamente significativa nos níveis de CEA. 
Também são sugeridos, para localização de lesões metastáticas, o uso de cintilografia com octreotide, ${ }^{91}$ análogo da somatostatina; associação de cintilografia com octreotide a anticorpos monoclonais anti-CEA (imuno-cintilografia); 92 tomografia por emissão de pósitrons; ${ }^{93}$ entre outros.

\subsubsection{SOBREVIDA E FATORES PROGNÓSTICOS}

Estudos a respeito de fatores prognósticos envolvidos no CMT são muitos e suas conclusões diversas. Todos concordam, porém, com os benefícios da ressecção completa da neoplasia durante o primeiro procedimento cirúrgico, tendo-se em mente que se trata de tumor com tendências à disseminação linfonodal precoce e insensível a terapias adjuvantes. A possibilidade do diagnóstico genético, por sua vez, é única, ao poder proporcionar a oportunidade de tireoidectomia e tratamento das cadeias linfáticas cervicais, antes mesmo que haja desenvolvimento do câncer ou que este se manifeste clínica ou bioquimicamente.

Saad et al. ${ }^{1}$ identificaram cinco variáveis relacionadas favoravelmente à sobrevida de pacientes tratados: idade menor que 40 anos, sexo feminino, Estádios I e II e neoplasia familiar vinculada à NEM2A. De 161 pacientes estudados, 33,8\% faleceram pela doença durante os períodos de seguimento que variaram de um mês a 28,8 anos (média de seis anos). Estádio foi considerado o fator prognóstico de maior relevância. 
Weber et al. ${ }^{94}$ estudaram 36 pacientes submetidos a tireoidectomia total e esvaziamento sistemático dos compartimentos cervicais. Sobrevida global em cinco anos foi calculada em $96,4 \%$ e sobrevida livre de doença em $71 \%$, para o mesmo período. Cura bioquímica foi alcançada em $38 \%$ dos pacientes esporádicos e em $50 \%$ dos pacientes familiares. Setenta e cinco por cento apresentavam metástases linfonodais à operação e metástases a distância foram diagnosticadas em quatro pacientes $(11 \%)$ após 18 meses, em média, do tratamento cirúrgico. Nenhum paciente estadiado como T4 obteve cura bioquímica e todos estes apresentavam acometimento linfonodal cervical. Possibilidade de normalização dos valores de CT foi maior quando o esvaziamento cervical foi realizado no mesmo tempo que a tireoidectomia. Sob análise multivariada, porém, somente a ausência de acometimento linfonodal cervical correlacionou-se com a possibilidade de cura bioquímica. Gênero, idade, forma clínica, estádio, multifocalidade e momento da linfadenectomia em relação à tireoidectomia não se caracterizaram como variáveis preditivas de evolução clínica.

Em estudo com 109 pacientes, Scopsi et al. ${ }^{95}$ calcularam as probabilidades de sobrevida em cinco, 10 e 20 anos em 65\%, 51\% e 30\%, respectivamente. Cinqüenta e três pacientes faleceram pela doença (seguimentos clínicos de um mês a 31 anos e cinco meses, média de cinco anos e quatro meses). Resultados de análise univariada demonstraram que gênero masculino, operação inicial incompleta, ausência histológica de amilóide, invasão de tecidos moles adjacentes à tireóide, metástases linfonodais bilaterais ou para mediastino e padrão heterogêneo de coloração de CT influenciaram positivamente recidivas. Já, idade ao diagnóstico, diâmetro neoplásico, multifocalidade, presença ou ausência de HCC, presença de metástases linfonodais 
cervicais unilaterais, metástases a distância e títulos pós-operatórios de CT sérica não influenciaram recidivas. Taxas de sobrevida global foram influenciadas pelas varáveis: idade maior que 60 anos ao diagnóstico, ressecção neoplásica incompleta, diâmetro da neoplasia maior que $4 \mathrm{~cm}$, invasão de tecidos adjacentes à tireóide, metástases linfonodais bilaterais ou para mediastino e metástases a distância. Gênero, presença ou ausência de amilóide em meio ao tumor, multifocalidade, presença ou ausência de HCC, metástases linfonodais unilaterais, padrão de coloração de CT e calcitonemia pós-operatória não influenciaram a sobrevida. À análise multivariada, gênero masculino, invasão de estruturas adjacentes e ausência de amilóide correlacionaram-se com recidiva neoplásica. Idade maior que 60 anos, invasão de estruturas adjacentes e presença de metástases a distância foram variáveis que favoreceram a possibilidade de óbito pela doença. Extensão do tumor primário para tecidos adjacentes foi o principal fator a comprometer o prognóstico.

Dados de 899 portadores de CMT foram analisados por Modigliani et al. ${ }^{9}$ Durante o seguimento (4,9 anos em média), 167 (18,6\%) óbitos ocorreram, sendo $70,7 \%$ por CMT $(13,1 \%$ de todo o grupo), $3,6 \%$ por feocromocitoma, $20,9 \%$ por outras causas e $4,4 \%$ por causas desconhecidas. Sobrevidas foram calculadas em $85,7 \%$ em cinco anos, 78,4\% em 10 anos e 70,1\% em 15 anos. Sob análise univariada, fatores preditivos positivos para sobrevida foram sexo feminino, menor idade ao diagnóstico, Estádios I ou II, tumor menor que $10 \mathrm{~mm}$ em seu maior diâmetro, ausência de metástases linfonodais cervicais, CMT NEM2A, CMTF-I e ausência de metástases a distância. Aqueles cujos tumores foram diagnosticados por rastreamento apresentaram melhor prognóstico que casos "index" que, por sua vez, tiveram melhor prognóstico em relação aos casos esporádicos. À análise 
multivariada, apresentaram impacto na sobrevida estádio e idade ao diagnóstico. Foram preditivos de cura bioquímica menor idade ao diagnóstico, sexo feminino, estádios iniciais, pequenas dimensões tumorais, ausência de metástases linfonodais cervicais, diagnóstico por rastreamento, neoplasias não vinculadas à NEM2B, níveis pré e pós-operatórios normais de CEA e títulos pré-operatórios baixos de CT. Sob análise multivariada, apenas estádio neoplásico à operação foi preditivo de cura bioquímica. Invasão neoplásica local não foi analisada no estudo e a conduta cirúrgica não foi uniforme entre os pacientes do grupo.

Ezabella ${ }^{8}$ observou $24 \%$ de cura, entre os 62 pacientes estudados. Ao comparar pacientes curados com não curados, observou, como variável estatisticamente significativa, idade (média de 26,13 $\pm 3,23$ anos para curados contra $39,38 \pm 2,31$ anos para não curados). Portadores das formas familiares diagnosticados por rastreamento apresentaram tendência maior à cura ( $40 \%$ de casos curados entre CMT-Fs rastreados, contra $17 \%$ de casos curados entre CMT-Es e 14,3\% entre casos "index" familiares), não estatisticamente significativa, porém. Nenhum caso familiar Estádio IV curou-se, assim como nenhum caso esporádico Estádios III ou IV também se curou. Estádio clínico dos pacientes curados foi estatisticamente diferente daqueles não curados, a favor dos Estádios I e II. Onze pacientes faleceram pelo CMT (17,7\%) e as sobrevidas em cinco, 10 e 15 anos foram calculadas em $86,4 \%, 76,2 \%$ e $63,5 \%$, respectivamente. Houve nítida tendência a favor dos casos familiares quanto à sobrevida. Diferenças estatísticas também demonstraram favorecimento aos indivíduos com menos de 20 anos de idade, Estádios I e II e portadores de neoplasias familiares diagnosticadas por rastreamento. Gênero não influenciou as taxas de sobrevida. 
Ao rastreamento familiar foi associada possibilidade de $100 \%$ de cura para os pacientes assim diagnosticados e prontamente tratados. ${ }^{10}$ Estes apresentaram menores taxas de metástases linfonodais, em relação aos pacientes também portadores de doença familiar, mas cujos tumores não foram diagnosticados por rastreamento. Dos pacientes assim diagnosticados, 94,7\% estavam curados ao final do seguimento (média de 6,3 anos), contra 32,5\% dos demais portadores de doença familiar (média de 8,8 anos de seguimento). Fatores de risco para recidiva ou persistência da doença foram assinalados como idade, forma clínica da doença, estádio, metástases linfonodais cervicais e extensão da tireoidectomia. Não influenciaram recidivas e persistências: gênero, multicentricidade e dissecção linfonodal. Quanto à análise estatística dos fatores preditivos de sobrevida, foram relevantes, em estudo univariado, idade ( $\leq 45$ anos), gênero feminino, ausência de sintomas, estádio e extensão da tireoidectomia. Sob análise multivariada, foram estatisticamente preditivos de sobrevida idade e estádio. Forma clínica, dimensões do tumor primário, multicentricidade neoplásica, presença de metástases linfonodais cervicais, esvaziamento cervical, radioterapia externa ou quimioterapia não influenciaram a sobrevida. Cento e quatro pacientes compuseram o estudo.

Hyer et al. ${ }^{11}$ analisaram 162 pacientes acompanhados por período médio de nove anos. Sobrevida global foi de $72 \%$ em cinco anos, 56\% em 10 anos, 40\% em 15 anos e $30 \%$ em 20 anos. Atenta-se ao fato do trabalho incluir pacientes atendidos entre 1949 e 1998, o que envolve, portanto, fase prévia aos programas de rastreamento. À análise univariada, foram preditivos de sobrevida idade ao diagnóstico, gênero (favorável quando feminino), tumores primários pequenos, doença linfonodal ausente, ausência de metástases a distância ao diagnóstico e 
extensão da ressecção tireóidea. Idade ao diagnóstico, doença linfonodal, metástases a distância e extensão da ressecção tireóidea permaneceram como significativas à análise multivariada. História familiar, multifocalidade e emprego de radioterapia não influenciaram as taxas de sobrevida global.

Em análise de 18188 casos de tumores tireóideos, Bhattacharyya ${ }^{6}$ calculou em $83,2 \%$ e $73,7 \%$ as possibilidades de sobrevida para portadores de CMT em cinco e 10 anos, respectivamente. Extensão neoplásica local, especialmente, e idade ao diagnóstico influenciaram a sobrevida destes pacientes. Gênero masculino e envolvimento linfonodal não obtiveram relevância estatística, embora fossem notadas suas tendências em contribuir com o comprometimento prognóstico.

Ao estudo univariado, Tavares ${ }^{69}$ observou que idade, forma clínica da doença, presença de metástases linfonodais cervicais e estádio clínico tiveram impacto no resultado terapêutico, assim como presença de metástases cervicais e idade o tiveram à análise multivariada. Foram estudados 32 pacientes.

Em análise de 905 casos, Kameyama et al. ${ }^{17}$ calcularam sobrevidas globais em cinco anos em 96,9\% para portadores de CMT NEM2A, em 100\% para CMTF-I, em 73,8\% para CMT NEM2B e em 90,8\% para casos esporádicos.

Já se correlacionou também genótipo e prognóstico. Tal correlação, entretanto, não é perfeita, pois o prognóstico depende de outros aspectos à apresentação inicial da neoplasia. Participação de alterações genéticas na determinação do prognóstico não é exclusiva das formas familiares da doença. Notou-se, por exemplo, correlação entre desenvolvimento de metástases a distância e mutações somáticas no códon 918 do RET em espécimes de carcinomas esporádicos, com conseqüente influência nas sobrevidas global e livre de doença. No entanto, 
mutação no códon 918 pode ocorrer após o desenvolvimento de metástases, como fenômeno secundário, sem influência direta no pior prognóstico dos pacientes cujos tumores a portam. ${ }^{50}$

Perda de alelos de genes supressores de tumores como NF2, 1-myc e p53 é mais freqüente entre neoplasias recorrentes e sua pesquisa pode ser teste prognóstico adjuvante. ${ }^{96}$ Já, a expressão do gene N-myc pode refletir a emergência de células imaturas de origem ectodérmica. Sua presença foi correlacionada com menores taxas de sobrevida. ${ }^{97}$

Correlacionou-se a expressão da proteína transmembrana CD97 com o estádio TNM e o prognóstico de portadores de CMT, estando elevada em tumores com estádios patológicos avançados. Expressão da também proteína transmembrana CD55 foi significativamente maior em espécimes neoplásicos, em relação à sua expressão em células "C" sadias. Ambas as proteínas podem facilitar a adesão da célula " $C$ " neoplásica às superfícies adjacentes e ser utilizadas como marcadores adicionais de prognóstico. ${ }^{98}$

A porcentagem de células neoplásicas imunocoradas pelo marcador de proliferação celular Ki67 foi calculada em estudo com espécimes de CMT. 99 Tumores primários que evoluíram com metástases haviam sido inicialmente classificados como Estádios III e IV e apresentaram índices mais elevados de Ki67 que aqueles Estádios I e II, e que não evoluíram com metástases. Quantificações de Ki67 foram progressivamente maiores em tumores primários, metástases e recidivas, respectivamente. Tempo de sobrevida foi menor entre aqueles com idades mais avançadas e altos níveis de Ki67. 
Expressão da oncoproteína Her2/neu em células neoplásicas do carcinoma medular também foi caracterizada como índice prognóstico, sendo significativa sua correlação com extensão neoplásica extratireóidea. ${ }^{100}$

\subsection{METALOPROTEINASES}

\subsubsection{A FAMÍLIA DAS METALOPROTEINASES}

De acordo com sua estrutura e substrato específico ao qual se liga, membros da família das metaloproteinases são classificados em subgrupos de colagenases, estromelisinas, estromelisinas "like", matrilisinas, gelatinases, MMPs transmembrana e outras MMPs. ${ }^{36,40}$ A Tabela 1 correlaciona cada MMP com seu subgrupo, peso molecular sob formas latente e ativa e substrato específico. São descritas mais de 20 MMPs diferentes e seus substratos também incluem, além de componentes da matriz extracelular e da membrana basal, moléculas de superfície celular e proteínas pericelulares que não participam da MEC. ${ }^{38}$ 
Tabela 1 - Classificação das MMP, subgrupos, pesos moleculares e substratos

\begin{tabular}{|c|c|c|c|c|}
\hline SUBGRUPO & MMP & MMP & $\begin{array}{c}\text { PESO } \\
\text { MOLECULAR } \\
\text { (latente/ativado) } \\
(\mathrm{kDa}) \\
\end{array}$ & SUBSTRATOS \\
\hline \multirow[t]{3}{*}{ Colagenases } & Colagenase-1 & MMP-1 & $52 / 41$ & $\begin{array}{l}\text { Colágenos I, II, III, VII, VIII e } \\
\text { X, agreguina, serpina, } \\
\text { macroglobulina-2 }\end{array}$ \\
\hline & Colagenase-2 & MMP-8 & $85 / 64$ & $\begin{array}{l}\text { Colágenos I, II, III, agreguina, } \\
\text { serpina, macroglobulina-2 }\end{array}$ \\
\hline & Colagenase- 3 & MMP-13 & $65 / 55$ & $\begin{array}{l}\text { Colágenos I, II, III, IV, IX, X e } \\
\text { XIV, gelatina, fibronectina, } \\
\text { laminina, osteonectina, serpina, } \\
\text { agreguina }\end{array}$ \\
\hline \multirow[t]{2}{*}{ Estromelisinas } & Estromelisina-1 & MMP-3 & $57 / 45$ & $\begin{array}{l}\text { Colágenos IV, V, IX e X, } \\
\text { elastina, gelatina, laminina, } \\
\text { agreguina, } \\
\begin{array}{l}\text { fibrilina, } \\
\text { osteonectina, inibidor da } \\
\text { proteinase-1, osteopontina, E- } \\
\text { caderina, proteína básica da } \\
\text { mielina }\end{array}\end{array}$ \\
\hline & Estromelisina-2 & MMP-10 & $56 / 47$ & $\begin{array}{l}\text { Colágenos IV, V, IX e X, } \\
\text { elastina, gelatina, laminina, } \\
\text { agreguina, osteopontina, E- } \\
\text { caderina }\end{array}$ \\
\hline \multirow[t]{2}{*}{$\begin{array}{l}\text { Estromelisinas } \\
\text { "like" }\end{array}$} & Estromelisina-3 & MMP-11 & $58 / 28$ & $\begin{array}{l}\text { Inibidores da serina protease, } \\
\text { inibidor da proteinase-1 }\end{array}$ \\
\hline & Metaloelastase & MMP-12 & $54 / 45$ & 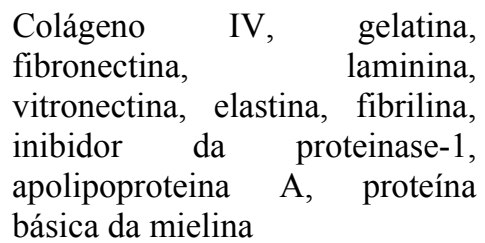 \\
\hline \multirow[t]{2}{*}{ Matrilisinas } & Matrilisina & MMP-7 & $28 / 19$ & $\begin{array}{l}\text { Elastina, fibronectina, laminina, } \\
\text { colágeno IV, tenascina, versican, } \\
\text { E-caderina, TNF }\end{array}$ \\
\hline & Matrilisina-2 & MMP-26 & 29/19 & $\begin{array}{l}\text { Gelatina, } \\
\text { enzima de conversão do TNF }\end{array}$ \\
\hline \multirow[t]{2}{*}{ Gelatinases } & Gelatinase A & MMP-2 & $72 / 67$ & $\begin{array}{l}\text { Gelatina, colágenos I, IV, V, VII } \\
\text { e X, fibronectina, tenascina, } \\
\text { fibrilina, osteonectina, proteína } 3 \\
\text { quimioatrativa de monócitos }\end{array}$ \\
\hline & Gelatinase B & MMP-9 & $92 / 67$ & $\begin{array}{l}\text { Gelatina, colágenos IV, V, VII, } \\
\text { XI e XIV, elastina, fibrilina, } \\
\text { osteonectina } 2\end{array}$ \\
\hline \multirow[t]{2}{*}{$\begin{array}{l}\text { "Membrane- } \\
\text { type" MMP }\end{array}$} & MT1-MMP & MMP-14 & $66 / 60$ & $\begin{array}{l}\text { Colágenos I, II, III, fibronectina, } \\
\text { gelatina, laminina, vitronectina, } \\
\text { agreguina, tenascina, perlecan, } \\
\text { fibrilina, inibidor da proteinase- } \\
\text { 1, macroglobulina-2, fibrina }\end{array}$ \\
\hline & MT2-MMP & MMP-15 & $68 / 62$ & $\begin{array}{l}\text { Fibronectina, laminina, } \\
\text { agreguina, tenascina, perlecan }\end{array}$ \\
\hline
\end{tabular}


Conclusão - Tabela 1

\begin{tabular}{|c|c|c|c|c|}
\hline SUBGRUPO & MMP & MMP & $\begin{array}{c}\text { PESO } \\
\text { MOLECULAR } \\
\text { (latente/ativado) } \\
(\mathrm{kDa})\end{array}$ & SUBSTRATOS \\
\hline \multirow[t]{4}{*}{$\begin{array}{l}\text { "Membrane- } \\
\text { type" MMP }\end{array}$} & MT3-MMP & MMP-16 & $64 / 55$ & $\begin{array}{lr}\text { Colágeno III, } & \text { fibronectina, } \\
\text { gelatina, caseína, } & \text { proteoglicanas } \\
\text { de cartilagem, } & \text { laminina-1, } \\
\text { macroglobulina-2 } & \end{array}$ \\
\hline & MT4-MMP & MMP-17 & $71 / 67$ & $\begin{array}{l}\text { Fibrina, fibrinogênio, percursor do } \\
\text { TNF }\end{array}$ \\
\hline & MT5-MMP & MMP-24 & $73 / 64$ & Proteoglicanas \\
\hline & MT6-MMP & MMP-25 & $62 / 58$ & $\begin{array}{l}\text { Colágeno IV, gelatina, } \\
\text { fibronectina, fibrina }\end{array}$ \\
\hline \multirow[t]{4}{*}{ Outras } & & MMP-19 & 57 & $\begin{array}{l}\text { Gelatina, agreguinas, proteína } \\
\text { oligométrica } \\
\begin{array}{l}\text { da } \\
\text { cartilaginosa, colágeno }\end{array} \\
\text { laminina }\end{array}$ \\
\hline & Enamelisina & MMP-20 & $54 / 43$ & $\begin{array}{l}\text { Amelogenina, agreguina, proteína } \\
\text { oligométrica } \\
\text { cartilaginosa }\end{array}$ \\
\hline & "Cysteine-array"- & MMP-23 & $\sim 66$ & Gelatina \\
\hline & & MMP-28 & $56 / 45$ & Caseína \\
\hline
\end{tabular}

FONTES: referências bibliográficas 38, 40, 102

NOTA: $\mathrm{kDa}=$ quilodalton

Dois elementos estruturais são compartilhados entre todos os membros da família das MMPs (Figura 1). O primeiro é um íon zinco, localizado no sítio catalítico da proteína. O segundo é o domínio pró-peptídico, que contém um resíduo cisteína, responsável pela manutenção da proteína sob sua forma latente (pró-MMP). ${ }^{36}$ As seqüências adicionais contribuem para o funcionamento único de cada tipo de enzima. Há um peptídeo sinalizador ligado ao pró-peptídeo que direciona a secreção da MMP latente e uma região rica em prolina liga o domínio catalítico ao domínio hemopexina, que determina os substratos específicos de cada MMP e seus inibidores, que, por sua vez, agem ao se ligarem ao domínio catalítico. Substratos e inibidores, porém, não são exclusivos para cada MMP. São descritos quatro componentes no grupo de TIMPs, ou inibidores teciduais das MMPs, denominados TIMP1 a TIMP4. 
MMP-7 e MMP-26 são as únicas que não contém o domínio hemopexina em sua estrutura e MT-MMPs (MT1-, MT2-, MT3- e MT5-MMP) contém em sua estrutura domínio transmembrana que as ancora à membrana plasmática e restringe sua atividade à superfície celular (Figura 1 - B). MT4-MMP e MT6-MMP, por sua vez, ancoram-se à membrana celular através de componente glicosil-fosfatidilinositol. A ativação das MT-MMPs, diferentemente das outras MMPs solúveis e secretadas para o meio extracelular, é intracelular. Agem não só na remodelação da matriz extracelular, mas também na ativação pericelular das MMPs. A MMP-23 é um tipo intermediário que também se ancora à membrana plasmática, mas se comporta como enzima solúvel. ${ }^{39,101,102}$

Figura 1- Estruturas esquemáticas dos domínios das MMPs (A) e MT-MMPs (B)
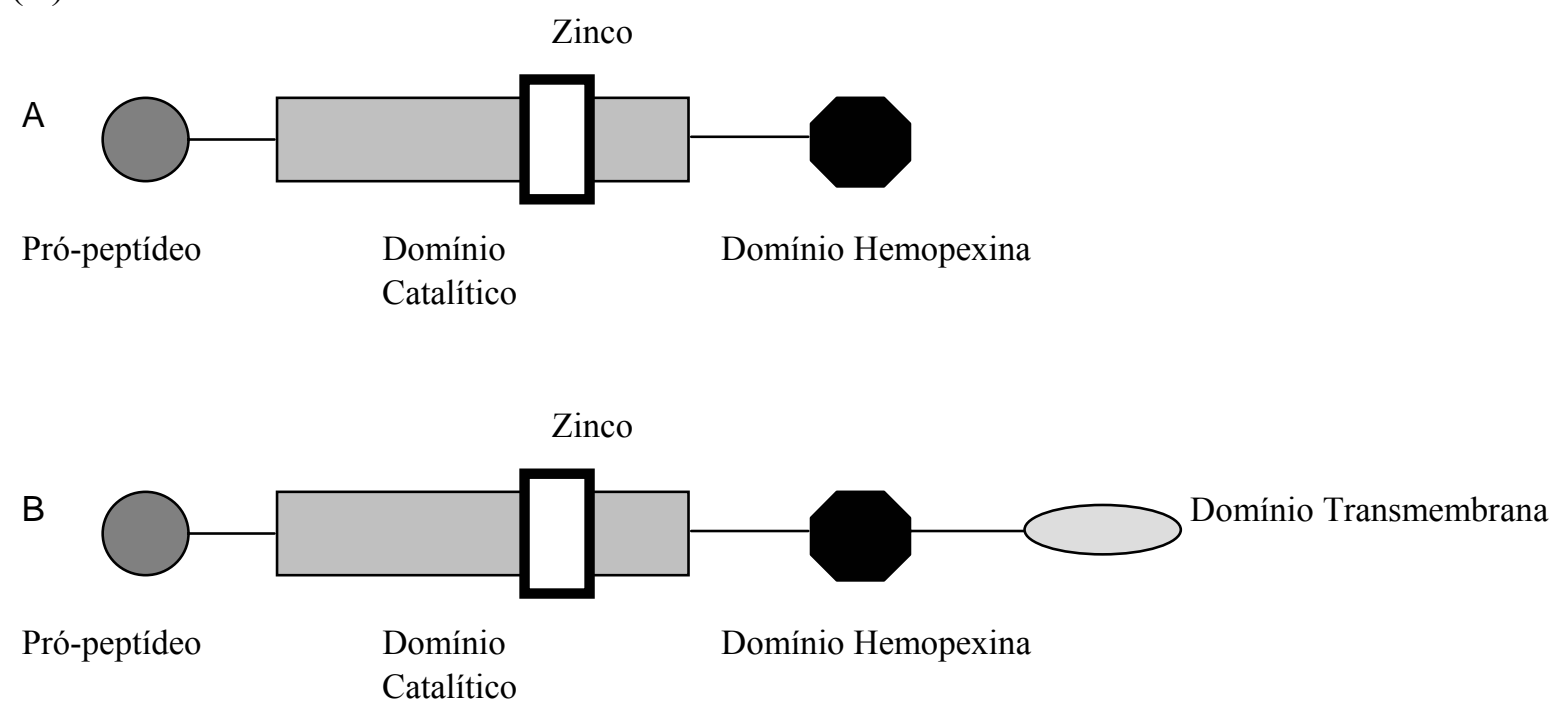

Figura 1- As MMPs contém um domínio pró-peptídico, responsável pela latência da enzima, e um domínio catalítico, portador de um íon zinco, estruturas sempre presentes e que caracterizam estas enzimas. São proteínas zinco-dependentes. Um domínio hemopexina determina substratos e inibidores de cada MMP (A). MMT-MMPs contém um domínio transmembrana adicional que as acopla à membrana plasmática da célula. Sua ativação é intracelular e apresentam-se ativadas à superfície da membrana plasmática (B) 


\subsubsection{CARCINOGÊNESE E A PARTICIPAÇÃO DAS METALOPROTEINASES}

Embora as metaloproteinases apresentem ampla gama de funções fisiológicas (desenvolvimento embrionário, reparos teciduais, ovulação, remodelação óssea, funções macrofágicas e neutrofílicas), grande interesse recai sobre seu potencial, livre de mecanismos regulatórios, na propagação do câncer. ${ }^{38}$ São ações que podem ser diretas, quando promovem proliferação de células neoplásicas e disseminação metastática através da degradação da matriz extracelular e da membrana basal, e indiretas, quando promovem angiogênese que proporciona nutrição e disseminação do tumor. ${ }^{103}$ Seu maior papel durante a invasão neoplásica não consiste na mera criação de caminhos pela quebra da barreira da $\mathrm{MEC}$, mas no rearranjo dos componentes desta matriz para melhor acomodar a migração celular. ${ }^{102}$ Diferentes MMPs interagem entre si e participam de diversos estágios do desenvolvimento do câncer, ${ }^{40}$ embora não sejam todos os componentes da família envolvidos na carcinogênese. ${ }^{104}$

A invasão neoplásica compreende múltiplos passos. Deve haver desconexão de aderências intercelulares e liberação de células neoplásicas isoladas, proteólise da lâmina basal e da matriz extracelular, deslocamento de células neoplásicas pela MEC, invasão de vasos linfáticos e sanguíneos, escape do sistema imunológico, adesão às células endoteliais, extravasamento para fora de vasos sanguíneos e linfáticos e proliferação no sítio secundário, além de angiogênese. ${ }^{38}$ 
Invasão ocorre a partir da interface tumor-hospedeiro, onde há troca de enzimas entre células neoplásicas e estroma, modulação da MEC local e estímulo para a migração celular. Esta última envolve a coordenação de mecanismos de adesão célula-célula e célula-matriz. Células neoplásicas e do estroma liberam fatores como citoquinas, quimioquinas e o indutor de MMP (EMMPRIN, “extracellular matrix metalloproteinase inducer”) com regulação parácrina positiva das MMPs, que, por sua vez, geram sinais quimiotáticos e também podem, ao degradar componentes da MEC, regular a disponibilidade e a atividade de fatores de crescimento e citoquinas. MMPs podem, assim, modular adesões e motilidade celulares. ${ }^{36,38}$

De adesões transitórias célula-célula e célula-matriz participam receptores transmembrana que se ligam a várias moléculas da MEC e são conhecidos como integrinas. Estas estão envolvidas nas vias de sinalização celular através de sua interação com componentes do citoesqueleto. ${ }^{105}$ Já foi demonstrada expressão de MMP-2 na superfície de células neoplásicas invasivas e endoteliais envolvidas na angiogênese e, a elas ligada, através da integrina $\alpha v \beta 3 .{ }^{106}$ Tais receptores expressam várias proteínas da MEC (vitronectina, fibronectina, laminina, colágeno tipo I, colágeno tipo IV e trombospondina) que estimulam a motilidade celular, também influenciada por compostos liberados pelas mesmas e por células hospedeiras. Estes compostos atraem células malignas para órgãos que os produzem e participam também como mitógenos. Alteração da forma da célula, rearranjos de seu citoesqueleto, alterações nas adesões celulares e alterações na fluidez da membrana plasmática também contribuem para a motilidade celular. ${ }^{105}$ 
Embora as bases genéticas da carcinogênese possam ser distintas para diferentes tipos e sítios neoplásicos, mecanismos de desenvolvimento de metástases podem ser semelhantes. Metástases lideram as causas de óbito entre portadores de neoplasias malignas e seu padrão de distribuição pode ser previsto, somente em parte, pelas drenagens venosa e linfática regionais. Células podem migrar isoladamente ou em grupos, quando mantém o contato célula-célula, mais comum em tumores de bem para moderadamente diferenciados. ${ }^{102}$ As superfícies de invasão destas células, ou grupos celulares desbravadores, expressam MMP-2 e MT1-MMP, enquanto suas presenças nas porções caudais da célula isolada ou nas células que seguem aquelas da frente de invasão no grupo são menores. Conhece-se também a relação entre MT1-MMP e CD44, intermediário na ligação desta MMP à actina do citoesqueleto, importante nas frentes de migração celular. MT-MMPs também podem degradar a transglutaminase-integrina, proteína de superfície celular, ligadora de fibronectina e cuja inativação reduz a adesão e a migração das células neoplásicas, dependendo da composição do meio extracelular. ${ }^{101,102}$

MMPs podem estar envolvidas em mecanismos de fuga do sistema imunológico circulante, através de interações das células neoplásicas com plaquetas e inibição de algumas funções, entre elas a proliferação de células imunocompetentes, como células T e "natural killers". O envolvimento de célula neoplásica por trombo plaquetário pode escondê-la do sistema imune e facilitar o extravasamento celular pela aderência do trombo neoplásico ao endotélio. ${ }^{38}$

Angiogênese ou neovascularização refere-se ao desenvolvimento de novos vasos sanguíneos e envolve proliferação de células endoteliais, sua migração, remodelação da MEC, formação tubular, recrutamento de estruturas adjacentes para 
sustentação dos vasos neoformados, anastomoses e desenvolvimento de membrana basal. ${ }^{107}$ São etapas que podem ser promovidas por fatores de crescimento liberados pelas células neoplásicas e denominados fatores angiogênicos. ${ }^{105}$ Sem angiogênese, a nutrição da massa neoplásica limita-se à difusão tecidual que alcança cerca de 0,2 mm de distância e seu crescimento não ultrapassa os 2 mm de diâmetro. ${ }^{38,107}$ MMPs participam desde a ruptura da membrana basal vascular à proliferação endotelial. Parte da influência das MMPs na angiogênese relaciona-se aos seus efeitos sobre moléculas pró-angiogênicas, como as da família dos fatores de crescimento endotelial vascular (VEGF ou "vascular endothelial growth factor"), e antiangiogênicas, como angiostatina. ${ }^{38}$

Apoptose é forma de morte celular programada que pode ocorrer em situações tanto patológicas como fisiológicas. MMPs podem tanto estimular como inibir mecanismos de apoptose. Apresentam efeitos pró-apoptóticos as MMP-1, -2, 3, -7, -9 e -11 e efeitos antiapoptóticos as mesmas MMP-2, -3, -7, -9 e -11. Tais ações ocorrem através da presença de matriquinas, fragmentos biologicamente ativos liberados na degradação da MEC, e pela interação direta de MMPs a receptores de superfície celular. Os resultados finais dependem do tipo de tecido envolvido e das concentrações relativas entre as MMPs e seus inibidores teciduais. A ação estimulatória de MMPs sobre a apoptose pode selecionar células resistentes ao processo e, portanto, colaborar com a progressão neoplásica final. ${ }^{108}$

Observou-se baixíssima atividade apoptótica, associada à presença da proteína bcl-2, em espécimes de diferentes estádios de carcinoma medular da tireóide. Em contraste, a atividade proliferativa celular também é pequena em condições de HCC e CMT, embora tumores de dimensões maiores e com maior 
atividade metastática expressem indícios de proliferação significativamente mais intensos. A resistência do CMT aos tratamentos rádio e quimioterápicos pode ser explicada pela proteção contra apoptose oferecida pela bcl-2. Sabe-se, porém, que mutação no RET proto-oncogene, por si só, pode determinar o grau de proliferação neoplásica e o curso biológico da doença, independentemente da regulação da apoptose. ${ }^{109,110}$

\subsubsection{REGULAÇÃO DAS METALOPROTEINASES}

A expressão do fenótipo maligno depende da proporção entre fatores estimulatórios e inibitórios e não é causada por gene ou proteína únicos. ${ }^{105}$ Quanto à ativação das MMPs, três mecanismos principais de regulação de sua expressão e atividade são descritos: transcrição gênica, ativação de MMPs latentes e sua inativação por inibidores teciduais. ${ }^{36}$

O principal mecanismo de regulação das MMPs reside na atividade transcricional dos genes relacionados. Esta é pequena, crescendo rapidamente em períodos de remodelação tecidual, o que inclui o desenvolvimento do câncer. ${ }^{38}$

Metaloproteinases solúveis são secretadas sob forma de pró-enzima latente (zimogênio) e requerem ativação extracelular para assumir sua forma ativa proteolítica. Tal mecanismo envolve a clivagem do domínio pró-peptídico e abertura do domínio catalítico no sítio de ligação do íon zinco, seguida de outras clivagens proteolíticas que tornam a enzima ativa e estável. ${ }^{36,102}$ Pode depender da ação de 
serina-proteases, com destaque para a plasmina, gerada a partir do plasminogênio por ações dos ativadores dos plasminogênios tipo-uroquinase e tipo-tecidual. ${ }^{36}$

Algumas MMPs fazem uso de outros membros da família para dar início ao processo de ativação enzimática. É o caso da pró-MMP-2, dependente da MT1-MMP e do TIMP-2 para um de seus mecanismos de ativação. ${ }^{36}$ Em região pericelular, a MT1-MMP liga-se ao TIMP-2 que, por sua vez, liga-se à pró-MMP-2 com indução da ativação da última. Há a participação de uma segunda MT1-MMP, não ligada ao TIMP-2. ${ }^{101,102}$ Metaloproteinases transmembrana, por sua vez, são ativadas no meio intracelular e então deslocadas para a superfície da membrana plasmática, com manutenção de um domínio intracelular. ${ }^{36}$

A inibição das formas ativas das MMPs pode dar-se pela ação de seus inibidores teciduais (TIMPs). São quatro TIMPs descritos (-1, -2, -3 e -4). Com exceção do TIMP-3, são secretados sob forma solúvel. Todos são capazes de efetuar fortes ligações com membros da família das MMPs, com conseqüente formação de complexos inibitórios. ${ }^{36}$ São importantes no estabelecimento de "balanço" entre síntese e degradação da MEC induzidas pelas MMPs. O conceito original, porém, de que TIMPs são responsáveis por efeitos contrários à progressão neoplásica nem sempre pode ser observado, uma vez que apresentam múltiplas funções biológicas, inclusive atividades promotoras de crescimento celular e a própria ativação da próMMP-2. ${ }^{36}$ Em grandes quantidades, o TIMP-2 também inibe a MT1-MMP, comprometendo a função da MMP-2 ao impedir sua ativação, além de inibi-la diretamente. $^{38}$

Fragmentos proteolíticos de substratos das MMPs, a2 macroglobulina, inibidor da $\alpha 1$ proteinase, entre outros, também agem como inibidores das MMPs. 
${ }^{38,39}$ RECK ("reversion-inducing cysteine-rich protein" ou proteína rica em cisteína indutora de reversão) é uma glicoproteína, tanto solúvel como aderida à membrana plasmática, que regula ao menos três membros da família das MMPs: MMP-2, MMP-9 e MT1-MMP. Seus mecanismos de ação são variados e incluem inibição da liberação da pró-MMP-9; inibição direta das MMP-2, -9 e MT1-MMP e inibição de processos catalíticos que levam à ativação da pró-MMP-2, entre outros. ${ }^{111,112}$ Já, o EMMPRIN (“extracellular matrix metalloproteinase inducer" ou indutor extracelular de MMPs) pode participar da ativação das MMPs através do estímulo da secreção destas enzimas e de seus estimuladores diretos, como a MT1-MMP. ${ }^{102}$

Catepsina G, elastase neutrofílica e proteinase-3, liberadas por polimorfonucleares associados a processo inflamatório perineoplásico, ativam também a pró-MMP-2, através de mecanismo dependente da participação da MT1MMP. É processo dose-dependente. ${ }^{113}$

Autores ${ }^{101,114-116}$ têm privilegiado, nas interpretações de suas pesquisas, valores relativos de MMPs, TIMPs e MT-MMPs correlatos nas neoplasias malignas, além de dosagens absolutas das classes enzimáticas acima.

\subsubsection{LOCALIZAÇÃO DAS METALOPROTEINASES E INIBIDORES TECIDUAIS DAS METALOPROTEINASES}

Há divergências sobre fontes e localizações de MMPs e TIMPs em tecidos neoplásicos. Questiona-se se células neoplásicas produzam MMPs ou estimulem 
células do estroma a produzi-las, via interação parácrina. ${ }^{37}$ Discrepâncias podem ser observadas entre a localização do material genético responsável pela transcrição das MMPs e sua expressão protéica.

Muitos dos resultados de pesquisas dependem do tipo de técnica empregada para a identificação dessas proteínas, que podem ser quantificadas no soro dos pacientes e localizadas nos tecidos. Entre as técnicas teciduais, algumas fazem uso de homogenados, proporcionando estudo do material genético celular e expressão protéica, mas não possibilitando visão espacial de sua disposição nos tecidos. Já, modelos "in situ" proporcionam preservação da arquitetura tecidual. Estudos têm demonstrado que a fonte celular das MMPs também pode diferir de acordo com o tipo de câncer e a MMP específica estudados. ${ }^{104}$ Seguem alguns exemplos.

Já se relatou presença de MMPs em células neoplásicas de carcinomas de mama por alguns autores, ${ }^{114}$ mas também em células do estroma, por outros. ${ }^{115}$

Em carcinomas de colo de útero, MMP-2 foi identificada tanto em células neoplásicas como do estroma em um terço de amostra analisada e, em metade da amostra, foi encontrada em células neoplásicas ou estromais. Em cerca de metade dos casos, TIMP-2 foi identificado em ambos os tipos celulares e, em número semelhante de casos, em células neoplásicas ou do estroma. Em um terço dos casos demonstrou-se presença de MT1-MMP em células do estroma ou do tumor e, em um pouco mais de $40 \%$ dos casos, em ambos os tipos celulares. ${ }^{116}$

Em carcinomas cólon-retais, MMP-2 foi identificada em células do estroma, enquanto que TIMP-2 foi encontrado em enterócitos de amostras de mucosa sadia e, em pequena quantidade, em enterócitos neoplásicos. Sua presença no estroma foi menos pronunciada em casos mais avançados. Entre sete espécimes de metástases, 
quatro apresentaram fortes sinais para TIMP-2 à hibridização "in situ”, porém sinais para MMP-2 no estroma foram menos intensos, quando comparados com os tumores primários. ${ }^{117}$

Em estudo ${ }^{118}$ de carcinomas epidermóides de língua, MMP-2, MT1-MMP e TIMP-2 foram identificados principalmente em células neoplásicas. Algumas células endoteliais e alguns fibroblastos no estroma adjacente aos tumores também apresentaram colorações positivas para as proteínas estudadas.

Okada et al. ${ }^{119}$ demonstraram, através de "probe" de DNA (molde préfabricado de seqüência específica de material genético), que MT-MMPs são transcritas em fibroblastos do estroma adjacente a carcinomas de cólon, mama e cabeça e pescoço, mas não em células neoplásicas, embora, à imuno-histoquímica, a enzima já tenha sido detectada nas células neoplásicas. Em carcinomas primários de cólon, maior expressão de MT-MMP foi observada em frentes de invasão neoplásica. Já, em carcinomas de mama e cabeça e pescoço, células expressando MT-MMPs estavam distribuídas através do estroma dos tumores. Os autores assumiram que, quando o componente extracelular das MT-MMPs é imunodetectado na superfície das células neoplásicas, esse poderia ter sido liberado pelos fibroblastos, onde a proteína é transcrita, e ligado a receptores de superfície das células neoplásicas. A mesma possibilidade foi aventada para MMP-2. Entretanto, MT-MMPs sem um domínio transmembrana podem não ter poder de ativação da pró-MMP-2, o que sugere que os ectodomínios das MT-MMPs imunodetectados nas células neoplásicas possam readquirir capacidade de ativar MMPs latentes ou ter, simplesmente, outra função. 
Em diferentes carcinomas de glândulas salivares, MMP-2, MT1-MMP e TIMP-2 foram imunolocalizados em células tumorais, porém, atividade gelatinolítica só foi identificada em ninhos neoplásicos de espécimes de carcinomas mucoepidermóides. $^{120}$

Quanto à glândula tireóide, demonstrou-se que a principal fonte de MMP-2, MMP-9, TIMP-1 e TIMP-2 no carcinoma papilífero são as células neoplásicas, em detrimento das células do estroma. Células foliculares não-patológicas, bem como células do estroma de áreas sadias, também foram positivas para a pesquisa destas enzimas. Expressões foram maiores em células foliculares sadias quando comparadas às do estroma, mas menores em relação às células neoplásicas. ${ }^{121}$

Em análise de valores séricos de VEGF e MMP-9 em portadores de carcinomas papilíferos da tireóide, Lin et al. ${ }^{122}$ propuseram hipótese das próprias células neoplásicas serem responsáveis pela produção destes fatores, ao basearem-se no progressivo aumento de suas concentrações à progressão do estádio da doença.

Através de técnicas de hibridização “in situ” em espécimes de carcinomas papilíferos, foram observadas as presenças de RNA de MT1-MMP tanto em células neoplásicas como em células do estroma ao redor de ninhos neoplásicos invasivos, embora células do estroma, em tecidos tireóideos sadios, não apresentassem sinais correspondentes à enzima. A expressão do RNA específico deve refletir a produção da proteína, que foi imunolocalizada em ambos os tipos celulares, coloração não observada nos casos de adenomas foliculares e controles. MMP-2 também foi imunolocalizada em células neoplásicas e em células do estroma, mas a coloração foi fraca ou ausente em estroma distante do carcinoma. Forte atividade gelatinolítica para MMP-2 foi identificada, através de zimografia "in situ", em células da neoplasia 
maligna, mas fraca atividade foi observada em componentes do estroma adjacente ao tumor e nenhuma atividade no estroma distante do câncer. Foram resultados compatíveis com os observados pela técnica de IH. Foi também demonstrado que, entre MT-MMPs, MT1-MMP é predominante no carcinoma da tireóide e seus níveis de mRNA correlacionaram-se diretamente com a ativação da pró-MMP-2. ${ }^{123}$

Zedenius et al. ${ }^{124}$ estudaram espécimes de carcinomas papilífero, folicular e anaplásico da tireóide, através de técnicas de hibridização "in situ” para o mRNA de MMP-2 e MMP-11. Os sinais para MMP-2, quando presentes, foram observados no estroma ao redor das frentes de invasão neoplásica, mas não no estroma tireóideo de áreas sadias. Todos os quatro casos de carcinomas anaplásicos e quatro, de cinco casos de carcinomas papilíferos, apresentaram sinais intensos, enquanto que em 10 , de 14 casos de carcinomas foliculares, foram observados sinais de graus variados. Nenhum adenoma folicular apresentou sinais de MMP-2, com exceção de dois casos de adenomas atípicos. Em nenhum caso, sinais de hibridização para MMP-11 foram demonstrados.

Tomita ${ }^{125}$ analisou três casos de hiperplasias de células "C" e 10 casos de carcinomas medulares da tireóide corados para MMP-2, MMP-9, TIMP-1 e TIMP-2, além de CT, cromogranina A e CEA, através de IH. Todas as células "C" nãopatológicas coraram-se intensamente para as MMPs e os TIMPs estudados. Nos casos de HCC, menor quantidade de células "C" coraram-se para MMPs e poucas para TIMPs. Células malignas dos CMTs obtiveram coloração relativamente menor em relação às células "C" não-neoplásicas, embora metade dos casos de câncer apresentasse células neoplásicas fortemente imunocoradas. As margens das neoplasias sofreram coloração mais intensa em relação aos centros das lesões. 
Em estudo de 22 espécimes de CMT, Cvejić et al. ${ }^{37}$ localizaram, através de IH, expressão intensa de MMP-2 no citoplasma da maioria das células malignas de todos os casos analisados. Também foi observada, mas em intensidade inferior, talvez por sua menor celularidade, positividade em células do estroma neoplásico, em células endoteliais e na interface entre células malignas e tecido sadio adjacente. Não se notou diferença de imunocoloração entre centro e periferia das neoplasias, como observado no estudo citado anteriormente. Células epiteliais de folículos adjacentes às neoplasias não foram coradas.

\subsubsection{METALOPROTEINASES E NEOPLASIAS DA TIREÓIDE}

Linhas de pesquisa tentaram correlacionar diversos tipos de neoplasias, em diferentes órgãos e tecidos, com as expressões e atividades das MMPs e proteínas correlatas, como também atribuir possíveis significados prognósticos aos resultados obtidos. MMP-2 é uma das principais metaloproteinases que apresentam ganhos de expressão e atividade nas neoplasias malignas e tem sido considerada marcadora de fenótipo maligno. ${ }^{104}$ Grande parte das linhas correlatas de pesquisa prioriza a análise de sua expressão tecidual.

Em relação a estudos de outros órgãos, como mamas e cólon, por exemplo, não foram muitas as linhas de pesquisa que correlacionaram neoplasias malignas da tireóide, especialmente o CMT, com MMPs e seus inibidores tissulares. Os resultados dos diferentes estudos também foram conflitantes em alguns aspectos. 
Campo et al. ${ }^{126}$ são pioneiros em publicação de 1992. Estudaram expressões imuno-histoquímicas de MMP-2 em 20 espécimes de carcinomas papilíferos da tireóide, sete carcinomas foliculares, três CMTs, nove adenomas foliculares, um bócio nodular, quatro tireoidites de Hashimoto, dois bócios difusos tóxicos, além de tecido tireóideo sadio e metástases linfonodais e ósseas. As células foliculares normais, em geral, não foram coradas. Imunocolorações discretas e focais foram observadas em células adjacentes a focos inflamatórios, especialmente em casos de tireoidite, e áreas de esclerose e fibrose associadas ao trauma de PAAFs ou a hemorragias espontâneas. Entre os nove espécimes de adenomas, foram observadas células positivas em cinco casos submetidos à PAAF, com padrões variáveis de coloração. Todos os casos de carcinomas foram positivos. Nos carcinomas papilíferos, a reatividade foi fraca em um caso (microcarcinoma), moderada em 10 e forte em nove casos. De dois casos de carcinomas foliculares minimamente invasivos, um apresentou imunocoloração moderada e, o outro, fraca. Os três casos de carcinomas de células de Hürthle apresentaram imunocolorações moderadas e, dois espécimes de carcinomas foliculares pouco diferenciados, imunocolorações intensas. Os três casos de CMTs foram moderadamente corados, através de padrão citoplasmático difuso. As lesões metastáticas estudadas eram provenientes de carcinomas papilíferos e foliculares e seus padrões de coloração variaram de moderado a intenso. Em dois casos de carcinomas foliculares, suas metástases apresentaram reatividade mais intensa que as lesões primárias correspondentes. Dois espécimes metastáticos foram negativos. Fibroblastos e células endoteliais coraramse em algumas regiões, com expressão intensa em áreas de angiogênese. O estudo foi conduzido com anticorpo específico à pró-MMP2 e anticorpo contra peptídeo 
presente nas formas ativa e latente da enzima. Os resultados obtidos com ambos os anticorpos foram equivalentes.

Kameyama ${ }^{127}$ identificou a expressão de MMP-1 em tecido fibroso de carcinomas papilíferos, entre ninhos de células neoplásicas e tecido tireóideo sadio. A enzima foi, provavelmente, expressa em fibroblastos e/ou macrófagos. Seu mRNA não foi identificado em células foliculares sadias ou patológicas. O autor relacionou a discreta expressão de MMP-1 com a pequena habilidade de invasão do carcinoma bem diferenciado da tireóide.

Korem et al., ${ }^{128}$ por sua vez, detectaram mRNA de MMP-1 em células tireóideas malignas, em contraste com indetecção em células benignas (cultura de células). Concluíram também que o "balanço" positivo MMP1:TIMP1 favorecia a degradação da MEC por tireócitos malignos.

Intensa expressão de MMP-2 não é suficiente para a ação da enzima "in vivo", uma vez que a mesma é secretada sob forma inativa. Partindo deste princípio, Nakamura et al. ${ }^{123}$ estudaram 26 espécimes de carcinomas papilíferos, nove de adenomas foliculares e 26 controles sadios, quanto às expressões de MMPs $(-1,-2$, 3, -7, -8, -9 e -13), MT-MMPs (-1 a -3) e TIMPs (-1 e -2). Entre as MMPs, somente as expressões de MMP-2 foram significativamente maiores em espécimes de carcinomas, em relação ao encontrado em tecidos tireóideos sadios e adenomas foliculares. As expressões de TIMP-1, mas não de TIMP-2, foram estatisticamente maiores nos carcinomas, quando comparadas ao observado em controles e adenomas, assim como a razão MMPs:TIMPs (níveis totais) também foi significativamente maior em amostras de carcinomas. Quando os níveis de produção de MMPs e TIMPs estudados foram comparados com fatores clinicopatológicos, não se obteve 
correlação positiva. A razão de ativação da MMP-2 (MMP-2: pró-MMP-2) foi significativamente maior em espécimes de carcinomas, contra as razões para controles e adenomas foliculares. A mesma razão apresentou correlação positiva para tumores com metástases linfonodais e para aqueles classificados como Estádio III. A transcrição de MT1-MMP foi observada em todas as amostras de carcinomas papilíferos estudadas, mas não em casos controle ou amostras de adenomas. Sua expressão foi maior nos casos de carcinomas com metástases linfonodais, mas não houve correlação com as dimensões neoplásicas. A taxa de ativação da pró-MMP-2 correlacionou-se positivamente com a expressão de MT1-MMP e pareceu ser bastante baixa em relação a outras neoplasias malignas.

Friguglietti et al. ${ }^{129}$ estudaram 74 pacientes tratados cirurgicamente por neoplasias foliculares da tireóide. Observaram que as imunorreações para MMP-9 foram significativamente maiores, quanto à proporção de células imunocoradas, nos carcinomas, quando comparadas à coloração nos adenomas, sem diferenças quanto à intensidade de coloração. A maior proporção de células coradas foi observada em neoplasias malignas avançadas.

Em estudo com linhas celulares derivadas de tumores anaplásicos da tireóide, foram identificadas, através de zimografia, expressões de MMP-2 e MMP-9. ${ }^{130}$

Carcinoma papilífero foi estudado por Maeta et al. ${ }^{121}$ quanto às expressões de MMP-2 e -9 e TIMP-1 e -2. As células malignas foram imunocoradas, na maioria dos casos, para as quatro proteínas estudadas. Células endoteliais e fibroblastos do estroma neoplásico foram ocasionalmente corados, mas em menor intensidade. Áreas não-neoplásicas também apresentaram expressões para as quatro proteínas, principalmente células foliculares e, em menor extensão, células do estroma. 
Zimografia com gelatina pode separar as MMPs em bandas proteolíticas. Conhecendo-se o peso molecular das formas ativa e latente, os autores observaram que $100 \%$ das amostras neoplásicas apresentavam bandas ativas para MMP-2 e -9, contra $66 \%$ dos espécimes teciduais não-neoplásicos das mesmas amostras. Atividade proteolítica foi significativamente maior nas neoplasias e os casos com maiores atividades de MMP-2 e -9 apresentaram tendência à maior coloração IH, validando este último método. Os resultados obtidos por "Western blotting" e imunohistoquímica também foram equivalentes. Elevadas expressões de MMP-2 correlacionaram-se positivamente com dimensões neoplásicas maiores, presença de metástases linfonodais, estádios clínicos avançados e invasões intratireóidea e vascular. Elevadas expressões de TIMP-1 e -2 correlacionaram-se com dimensões neoplásicas maiores, estádios clínicos avançados e consideráveis invasões intratireóidea e vascular. Quanto às metástases a distância, os resultados não alcançaram significância estatística para nenhuma das proteínas analisadas, embora só um paciente as tenha desenvolvido.

Outros autores, ${ }^{131}$ porém, associaram a expressão de MMP-2 ao diagnóstico diferencial do carcinoma papilífero da tireóide, mas não ao seu prognóstico. Em espécimes de carcinomas papilíferos foram observadas expressões de MMP-2 significativamente maiores que em controles sadios, inclusive em tecido perineoplásico, adenomas, bócios e carcinomas folicular e medular. Sugeriram, então, que os carcinomas folicular e medular, como neoplasias mais agressivas, devessem contar com outras MMPs envolvidas em seus processos de progressão. Não houve diferença nos resultados de sua quantificação entre os portadores de metástases linfonodais e aqueles com doença localizada. Níveis mais elevados de 
MMP-2 e maior atividade desta enzima foram identificados no carcinoma papilífero por zimografia em gelatina e ELISA (“enzyme-linked immunosorbent assay”) e sua expressão imunolocalizada no epitélio neoplásico. As quantificações de MMP-9 e TIMP-2 foram semelhantes entre espécimes sadios e patológicos.

Em estudo ${ }^{122}$ de dosagens séricas de MMP-9 e VEGF em 30 pacientes portadores de carcinomas papilíferos da tireóide, foram observados valores significativamente maiores em relação a pacientes sadios e em relação a portadores de nódulos tireóideos benignos. Entre portadores de nódulos benignos e controles saudáveis, não existiram diferenças estatísticas quanto às dosagens séricas acima. Quando portadores de câncer foram agrupados conforme seu estádio TNM, aqueles Estádios I e II não apresentaram diferenças nas dosagens em relação aos controles e portadores de bócios, já, aqueles classificados como Estádios III e IV, apresentaram dosagens significativamente maiores em relação aos controles e portadores de bócios. Nos casos de câncer, notou-se correlação positiva entre níveis de VEGF e MMP-9. Seus títulos também foram significativamente maiores entre portadores de tumores de maiores dimensões, metástases linfonodais cervicais, invasão extratireóidea, metástases distantes e Estádios III e IV. Os autores sugeriram possível participação de MMP-9 na regulação da angiogênese, mas desaconselharam o uso dos marcadores como armas diagnósticas.

Tomita ${ }^{125}$ estudou as expressões imuno-histoquímicas de MMPs e TIMPs em células "C" tireóideas. Selecionou três casos de HCCs e 10 de CMTs (seis esporádicos e quatro familiares). As células "C" sadias foram fortemente positivas para MMP-2 e -9 e TIMP-1 e -2 , enquanto que, em HCCs, menor quantidade de células foram imunocoradas para MMPs e poucas células o foram para TIMPs. 
Padrões de imunocoloração não foram diferentes entre as duas formas clínicas de CMT. Em metade dos casos as células neoplásicas foram coradas em menor intensidade, quando comparadas às células "C" não-neoplásicas, e, em outra metade da amostra, suas colorações foram tão intensas quanto. Esta observação também valeu para CT, CEA e cromogranina. Um dos casos de CMT apresentou discreta coloração para MMPs e coloração ausente para TIMPs, enquanto que sua metástase hepática corou-se mais intensamente para as duas classes de marcadores. Células foliculares foram negativas para os marcadores testados. O mesmo autor já havia detectado as presenças de MMP-2 e -9 e TIMP-1 e -2 em células da hipófise anterior, adenoma hipofisário, glândulas paratireóides e adenomas correspondentes, células estas que compartilham da mesma característica neuroendócrina das células "C". Foi proposta, assim, inclusão das MMPs e dos TIMPs citados como possíveis marcadores de células neuroendócrinas. Apesar da imunocoloração para MMPs em células neoplásicas ter sido menor que em células " $\mathrm{C}$ " sadias, a imunocoloração das primeiras foi ainda menor para TIMPs, fato que poderia indicar "balanço" favorável à atividade proteolítica nos CMTs.

Vinte e dois casos de carcinomas medulares esporádicos foram analisados por Cvejić et al. ${ }^{37}$ que observaram imunocoloração presente e difusa para MMP-2, embora em intensidade variável, em todos os casos examinados. Também foi observada coloração em células do estroma intraneoplásico e nas bordas das lesões. Células foliculares sadias foram negativas à reação IH. Não se notou, porém, associação aparente entre intensidade da expressão de MMP-2 e estádio neoplásico, uma vez que portadores de tumores já com metástases linfonodais apresentavam imunocolorações semelhantes àqueles com doença restrita. Sugeriram que altas taxas 
de produção de MMP-2 poderia ser evento precoce na progressão do CMT, mas não consideraram a proporção MMP:TIMP na interpretação de seus resultados.

\subsubsection{METALOPROTEINASES E NEOPLASIAS DE OUTROS ÓRGÃOS}

MMP-19 parece ter papel protetor contra a progressão do câncer de mama, enquanto que MMP-2 tende a correlacionar-se com sua progressão para fenótipos mais agressivos e indiferenciação celular. ${ }^{103}$ Outros também correlacionaram expressão e atividade de MMP-2 com fenótipo maligno e progressão das lesões para estádios mais avançados, ${ }^{114,115,132,133}$ bem como a expressão de TIMP-2 com prognóstico desfavorável ${ }^{134}$ ou não, ${ }^{133}$ contraditoriamente. MMP-2 é ativadora de MMP-13, que também pode colaborar com a progressão do câncer de mama ao participar de eventos microinvasivos. ${ }^{135}$

Demonstrou-se correlação positiva entre progressão neoplásica e comprometimento prognóstico de portadores de carcinomas epidermóides do trato aéreo-digestivo alto com expressões de MT1-MMP, ${ }^{135,136}$ MMP-1, ${ }^{137}$ MMP-9, ${ }^{137,138}$ MMP-13, ${ }^{139}$ MMP-2, ${ }^{135,136,138,140}$ TIMP-1, ${ }^{136,137,139}$ e TIMP-2, ${ }^{135,140}$, como também correlação prognóstica com níveis séricos de TIMP-1 e MMP-9 em portadores de tumores malignos de pulmão. ${ }^{141}$ Zhou et al. ${ }^{142}$ demonstraram que a MMP-2 assume importante função na iniciação e progressão do câncer de pulmão, a partir de identificação de polimorfismos em região gênica promotora de MMP-2 conferindo 
efeito "ganho-de-função" à enzima e aumento da susceptibilidade de seus portadores à doença maligna.

Correlacionou-se o aumento da expressão de MMP-2 à progressão do melanoma maligno ${ }^{143}$ e da leucemia linfóide aguda em adultos, por grupo ${ }^{144}$ que associou a expressão da mesma MMP-2 a prognóstico favorável em pacientes com leucemia mielóide aguda. ${ }^{145}$

No carcinoma gástrico foram demonstradas correlações positiva da expressão de MMP-9 e negativa da expressão de TIMP-1 com a progressão para estádios avançados da doença e conseqüente comprometimento prognóstico. Os casos mais avançados contaram com expressões positivas para MMP-9 e negativas para TIMP1, com destaque para a proporção entre as duas proteínas, em cada caso. ${ }^{146}$ Notou-se associação entre a razão das concentrações de MMP-2 e TIMP-2 e a progressão do estádio neoplásico em carcinomas cólon-retais, embora lesões metastáticas apresentassem redução da razão entre as duas proteínas ao abrigarem baixas concentrações de MMP-2, semelhantes às da mucosa sadia ou do adenoma. ${ }^{116}$ Dosagens de MMP-9 também foram correlacionadas ao prognóstico no carcinoma de cólon. ${ }^{147}$ Outros ${ }^{148}$ correlacionaram concentrações de MMP-2 e -9 em neoplasias malignas de cólon e pâncreas com suas potencialidades para desenvolvimento de metástases hepáticas. As concentrações de TIMP-2 também foram maiores entre espécimes primários que evoluíram com tais metástases.

Foram associadas a progressão de carcinomas de endométrio ${ }^{149}$ às expressões de MMP-2, MMP-9 e MT1-MMP e, de carcinomas de ovário, às expressões de MMP-2, MMP-9 e TIMP-2, ${ }^{150,151}$ sendo que a expressão de MT1-MMP em células do estroma pareceu relacionar-se a efeito protetor, mas não quando expressa em 
células malignas de tecidos metastáticos. ${ }^{150}$ As expressões dos mesmos MMP-2 e TIMP-2, principalmente quando analisadas em conjunto, também foram correlacionadas ao estádio neoplásico e comprometimento prognóstico em casos de carcinomas de colo uterino. ${ }^{119}$ Observações semelhantes foram feitas para carcinomas de vesícula biliar. ${ }^{152}$ As expressões de MMP-2, MMP-9 e TIMP-1 também puderam ser classificadas como preditivos de progressão do estádio neoplásico em carcinomas de trato urinário ${ }^{153}$ e, a expressão de MMP-2, em carcinomas de bexiga. ${ }^{154}$

Pinheiro et al. ${ }^{155}$ sugeriram o envolvimento de MMP-1, -2 e -9 na proliferação de células do ameloblastoma, especialmente em linhas de invasão neoplásica da interface tumor-osso.

Foram descritos apenas alguns exemplos de correlações clínicas com expressões de MMPs em diferentes tecidos neoplásicos.

\subsubsection{INIBIDORES DAS METALOPROTEINASES}

A partir de estudos que demonstraram a participação de MMPs em vários estágios da carcinogênese e em diferentes espécimes tumorais, têm-se considerado tais enzimas como alvos promissores à terapia do câncer através do desenvolvimento de inúmeros inibidores sintéticos e naturais das MMPs, com o objetivo de prevenir ou reduzir a progressão neoplásica. Muitas substâncias ${ }^{36,40,99,100,156}$ têm sido testadas contra as MMPs, em monoterapia ou em associação com quimioterápicos, com 
resultados, porém, desapontadores, principalmente em vista de que os ensaios clínicos são conduzidos em pacientes já em estádios avançados da doença. Tratam-se também de substâncias citostáticas e não citotóxicas, mas que também podem ter efeitos antiangiogênicos. Portadores de neoplasias malignas de diferentes órgãos têm sido incluídos nos ensaios clínicos.

Inibidores das MMPs podem controlar o crescimento neoplásico ao estimularem o desenvolvimento de cápsula fibrosa ao redor do tumor, ao inibirem a angiogênese induzida pela neoplasia ou ao induzirem a apoptose de células malignas. 100

Como uma das explicações pelos pobres resultados terapêuticos do emprego dos inibidores das MMPs, ressalta-se que estas podem ter papel paradoxal na carcinogênese, ao inibirem a progressão neoplásica em determinadas situações. ${ }^{157}$

Para que terapia adequada seja instituída para cada paciente, procura-se, por um lado, desenvolver inibidores os mais específicos possíveis, inclusive com o intuito de se controlar seus efeitos adversos, e, por outro lado, identificar quais MMPs atuam especificamente em cada estágio da carcinogênese, de cada tipo de tumor. Ainda há o quê se aprimorar nos conhecimentos das particularidades dos tumores e dos mecanismos de defesa do organismo hospedeiro envolvido, com desenvolvimento de maior especificidade aos agentes antineoplásicos ${ }^{99}$ e definindose, enfim, se a inibição das MMPs poderá ser parte de terapias futuras contra o câncer. ${ }^{157}$ 
4 MÉTODOS 


\section{MÉTODOS}

\subsection{CASUÍSTICA}

Foram selecionados 37 pacientes dos Serviços de Cirurgia de Cabeça e Pescoço e de Endocrinologia do Hospital das Clínicas da Faculdade de Medicina da Universidade de São Paulo - São Paulo (31 casos), do Instituto Brasileiro de Controle do Câncer em São Paulo (um caso) e de clínica privada (cinco casos), também em São Paulo, todos portadores de CMTs tratados cirurgicamente em primeiro momento, para estudo retrospectivo.

Só foram incluídos os pacientes cujos dados clínicos e anatomopatológicos estavam presentes em seus prontuários médicos e cujos espécimes cirúrgicos encontravam-se disponíveis e razoavelmente conservados para que o estudo IH pudesse ser realizado, mas, que antes, fossem comprovadas a precisão do diagnóstico anatomopatológico de CMT e a presença de lesões correspondentes no material disponível. Foi privilegiada a análise de aspectos clinicopatológicos pertinentes ao prognóstico, segundo revisão bibliográfica realizada. Quarenta e um pacientes, entre os inicialmente selecionados para o estudo, foram inelegíveis, pela ausência de dados clínicos suficientes ou indisponibilidade de seus materiais anatopatológicos. Em alguns casos, inicialmente selecionados, análises cuidadosas de todos os blocos de inclusão em parafina não foram capazes de identificar a presença do CMT, 
provavelmente pelo seu uso prévio em outras linhas de pesquisa, sendo os pacientes em questão excluídos do estudo.

Cura bioquímica foi considerada como normalização dos títulos séricos de CT, preferencialmente sob estímulo, após o tratamento operatório, e, recidiva, como elevações destes níveis após, no mínimo, seis meses da operação com intenção curativa e normalização das dosagens. Manutenção dos níveis séricos de CT acima dos limites de referência ou sua elevação, mesmo após redução dos resultados das dosagens ou até sua normalização, mas por período inferior a seis meses, foi indicativa de persistência neoplásica. Pacientes portadores de dosagens séricas elevadas de CT, mas sem evidências clínicas ou imagenológicas de neoplasia cervical ou metástases a distância, foram considerados portadores de doença bioquímica.

Em relação à sua situação clínica na última visita ambulatorial, os pacientes foram classificados como vivos sem doença, vivos com doença ou mortos pela neoplasia. Doença loco-regional ou cervical foi identificada simplesmente como local, pois nem sempre estiveram disponíveis informações relativas à exata localização da neoplasia (loja tireóidea ou cadeias linfonodais cervicais). Nenhum paciente deste grupo faleceu por outras causas que não o CMT, até a data final dos seguimentos.

O tempo médio de seguimento foi de 65,62 meses (quatro a 189 meses, coeficiente de variação calculado em 78,03\% e mediana calculada em 57 meses), em período de junho de 1982 a fevereiro de 2005, quando a atualização dos dados clínicos foi encerrada. O tempo de seguimento foi considerado a partir do tratamento cirúrgico inicial até o último retorno ou óbito e os períodos para cura ou recidiva 
determinados de acordo com seus diagnósticos de cura ou recidiva, respectivamente. O período livre de doença compreendeu desde o tratamento cirúrgico inicial ao diagnóstico de recidiva neoplásica ou último retorno ambulatorial, estando o paciente vivo e sem doença.

Por alguns períodos, as análises laboratoriais de CT e/ou CEA séricos foram interrompidas no Hospital das Clínicas da Faculdade de Medicina da Universidade de São Paulo, o que prejudicou o seguimento oncológico dos pacientes, bem como as curvas evolutivas dos marcadores. Os métodos utilizados para as dosagens séricas de CT também variaram no decorrer dos anos, contando, inclusive, com valores de referência distintos, e nem todos os métodos consideraram as diferenças de valores de referência para a CT sérica em relação aos sexos, como se faz atualmente. Neste estudo, foram considerados os valores relativos de calcitonemia, ou seja, o número de vezes de aumento em relação ao máximo valor de referência, para cada paciente, no momento do diagnóstico do CMT. Considerou-se se as dosagens pós-operatórias de CT foram positivas, mas dentro dos limites da normalidade ou não. Neste momento, os valores considerados para o marcador também foram relativos: entre três e 10 vezes o valor máximo de referência, maior que 10 até 30 vezes, maior que 30 até 100 vezes e maior que 100 vezes. O máximo valor observado durante a evolução de cada paciente foi utilizado para análise. Quanto às dosagens séricas de CEA, foram observados seus valores relativos também ao diagnóstico do CMT e se os valores das dosagens no seguimento dos pacientes estiveram dentro dos limites da normalidade ou elevadas, acompanhando possíveis persistências ou recidivas.

Considerou-se se o diagnóstico etiológico havia sido realizado durante ou logo após a operação, a partir de estudo anatomopatológico da lesão, ou em momento 
prévio ao tratamento operatório. Neste último caso, os pacientes foram agrupados entre aqueles cujos diagnósticos foram realizados em vigência de sinais como aumento de volume tireóideo e adenomegalias cervicais ou sintomas sistêmicos, por rastreamento (familiar, bioquímico e/ou genético) ou por exames de rotina que incluíram USG cervical, sendo a lesão tireóidea um achado acidental.

Os pacientes estudados também foram agrupados entre portadores da forma esporádica do CMT e portadores das formas familiares da neoplasia, quando a presença de endocrinopatias associadas também foi observada. Entre aqueles provenientes do Hospital das Clínicas, todos são, ou foram, também acompanhados no Serviço de Endocrinologia pela Dra ${ }^{\mathrm{a}}$. Marilza Cristina Legrazie Ezabella, que forneceu dados genealógicos e evolutivos essenciais. Treze casos, entre os selecionados para este estudo, foram diagnosticados por rastreamento genético e/ou bioquímico.

Os pacientes provenientes de clínica privada e do Instituto Brasileiro de Controle do Câncer foram todos classificados como portadores de CMT-E, através de pesquisa de mutações do RET proto-oncogene, realizada em laboratório de iniciativa privada, ou por não apresentarem história familiar compatível com CMT-F, ausência de HCC associada, ausência de sinais clínicos ou imagenológicos de feocromocitoma e HPT, além de rastreamento bioquímico familiar negativo.

Os pacientes foram submetidos à tireoidectomia total e a esvaziamentos cervicais classificados como eletivos ou pré-sintomáticos (pacientes Estádio N0) e terapêuticos (pacientes Estádio N1), bem como envolvendo o compartimento central (níveis linfonodais cervicais VI e VII) e/ou os compartimentos laterais do pescoço (níveis II, III, IV e, eventualmente, V) unilateral ou bilateralmente. Linfonodos do 
compartimento central foram generalizados como cervicais, independentemente do nível VII referir-se ao mediastino superior. Em dois casos as operações iniciais realizadas foram consideradas paliativas.

Outros dados observados para cada paciente incluíram idade ao diagnóstico (anos completos); gênero; tipo de operação inicialmente realizada (tireoidectomia total ou não e tipo de esvaziamento cervical, se realizado); dados anatomopatológicos segundo laudos de exames originais (maior diâmetro de maior lesão, presença ou ausência de multicentricidade neoplásica, presença ou ausência de invasão da cápsula tireóidea e de estruturas adjacentes, presença ou não de invasão ângio-neural, tireoidopatias associadas, presença ou ausência de $\mathrm{HCC}$, presença ou não de amilóide em tecido neoplásico, número de linfonodos acometidos pela neoplasia e sua localização e presença ou não de extensão neoplásica extralinfonodal); estadiamento TNM; presença ou não de metástases a distância ao diagnóstico; caracterização de cura bioquímica ou persistência neoplásica; caracterização de recidiva neoplásica, quando existente, quanto ao período do diagnóstico em relação à cura bioquímica (meses completos); localização da doença persistente ou recidivada e seu tratamento; realização ou não de terapia complementar, bem como evolução final. Os pacientes foram classificados como vivos sem doença ou vivos com doença em função de suas condições no último retorno ambulatorial, além de morto pela doença. (Exemplo de ficha do protocolo aplicado a todos os pacientes em ANEXO B).

Idades foram consideradas em anos completos de vida no momento do diagnóstico do CMT e os pacientes agrupados em faixas etárias assim denominadas: A - pacientes com até 20 anos completos de idade; B - entre 21 e 30 anos de idade; 
$\mathrm{C}$ - entre 31 e 40 anos de idade; D - entre 41 e 50 anos de idade e $\mathrm{E}$ - pacientes com mais de 50 anos.

Lesões primárias também foram agrupadas em função de seu maior diâmetro: A - neoplasias com até $5 \mathrm{~mm}$ em seu maior diâmetro; B - neoplasias com diâmetros maiores que $5 \mathrm{~mm}$, mas menores que $15 \mathrm{~mm}$; $\mathrm{C}$ - neoplasias de $15 \mathrm{~mm}$ ou mais, mas menos que $30 \mathrm{~mm}$ e $\mathrm{D}$ - neoplasias com diâmetros maiores ou iguais a $30 \mathrm{~mm}$.

Como referência para o estadiamento dos pacientes estudados, foi utilizado o sistema TNM, atualizado pela AJCC em 2002 (ANEXO A) - publicação brasileira de 2004. ${ }^{71}$ Principalmente em alguns laudos anatomopatológicos antigos, estavam ausentes alguns dados pertinentes como o maior diâmetro da lesão principal, observação relevante para o estadiamento TNM, entre outras notas relativas à integridade da cápsula tireóidea, invasões ângio-neurais e presença de HCC, por exemplo. Na ausência destes dados, os casos correspondentes não foram considerados na análise estatística de cada variável.

A última atualização dos dados clínicos dos pacientes envolvidos no estudo foi realizada em fevereiro de 2005 . Nove pacientes não retornavam mais às consultas ambulatoriais há, pelo menos, 18 meses. Quatro pacientes não apresentavam evidências clínicas ou laboratoriais de neoplasia ao abandonarem o seguimento clínico e cinco pacientes, portadores de doença ativa, abandonaram o seguimento. Entre estes, uma paciente (caso 19) encontrava-se sabidamente viva (informações de familiares) ao final da coleta dos dados. Esta havia abandonado o seguimento em vigência de doença bioquímica persistente e sem evidências de doença local ou a distância. O paciente relativo ao caso 11, portador de evidências clínicas de doença cervical, mas recusando-se a ser submetido a novo tratamento cirúrgico, não 
retornava às consultas, mas estava vivo ao final da coleta dos dados. Dois pacientes (casos 5 e 9), sem evidências de doença ativa até a última consulta, abandonaram o seguimento no Hospital das Clínicas e foram classificados como vivos e sem doença através de informações de familiares. Os casos 1 e 17 também haviam sido considerados curados à última consulta. $\mathrm{O}$ primeiro foi seguido por 25 meses após a operação e não retornava ao ambulatório desde 1984 e o segundo foi considerado curado após a operação, mas seguido somente por quatro meses, não retornando desde 1990. Não é incomum a ausência dos pacientes nos retornos ambulatoriais por períodos que ultrapassam anos, sendo que alguns são domiciliados em outros estados. O tempo de seguimento para cada paciente foi calculado em meses completos (Figura 2, Gráfico 1). As informações para cada caso estudado estão especificadas no ANEXO C deste trabalho. O estudo foi aprovado pela Comissão de Ética para Análise de Projetos de Pesquisa (CAPPESQ) em 12 de junho de 2002, sob o número 16.416/02.

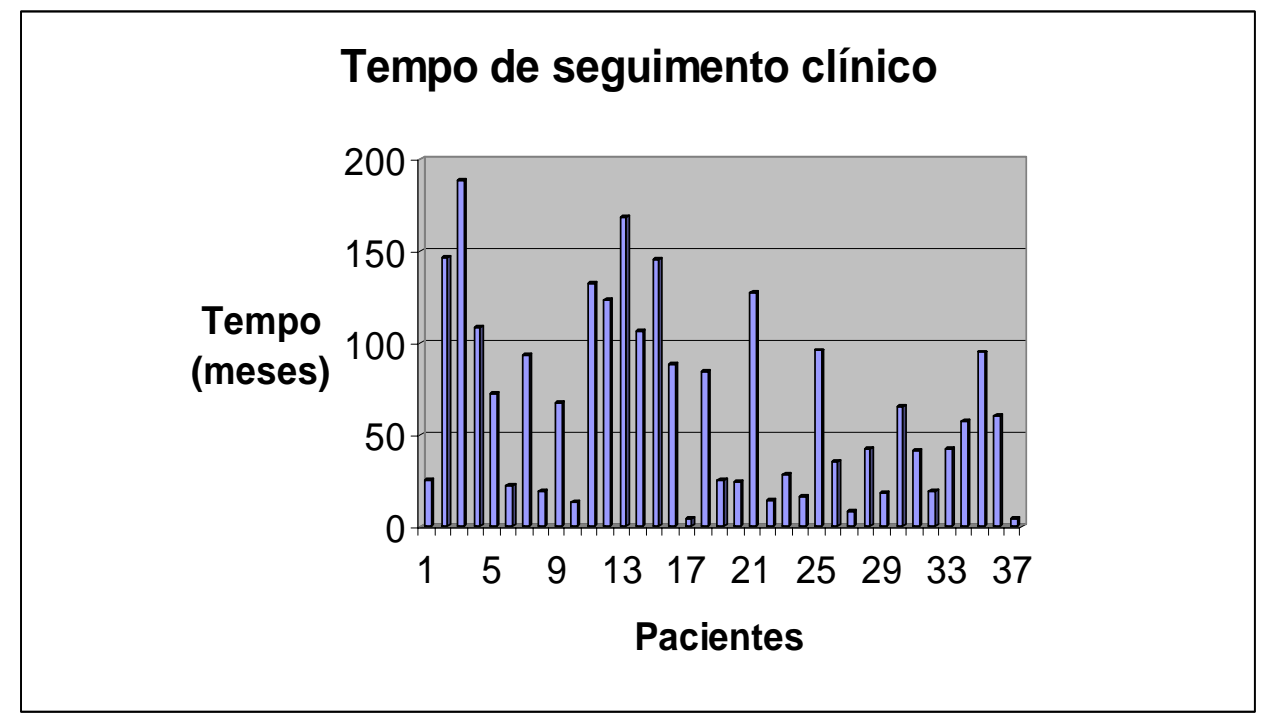

Figura 2. Gráfico 1 - Representação do tempo de seguimento clínico (em meses) para cada integrante do estudo 


\subsection{MÉTODOS}

Os dados clinicopatológicos foram coletados através de revisão de prontuários médicos. Comunicação pessoal com alguns pacientes ou familiares foi utilizada para esclarecimentos sobre as condições atuais, ou seja, vivo ou falecido.

Os espécimes teciduais, fixados em formalina a $10 \%$ e processados rotineiramente em parafina, foram seccionados (secções de $3 \mu \mathrm{m}$ ), acondicionados em lâminas e corados com hematoxilina e eosina (HE). Através da leitura das lâminas em microscópio de luz, foram selecionados os blocos que melhor representassem cada caso, quanto às neoplasias primárias e lesões metastáticas, se presentes. Os cinco casos cujas análises iniciais das peças cirúrgicas não incluíam estudo IH com CT, foram submetidos a esta coloração e os diagnósticos de CMT confirmados. Na Figura 3, exemplo de CMT primário em corte histológico sob coloração HE e na, Figura 4, exemplo de lesão metastática de CMT em linfonodo, também em corte histológico sob HE. 


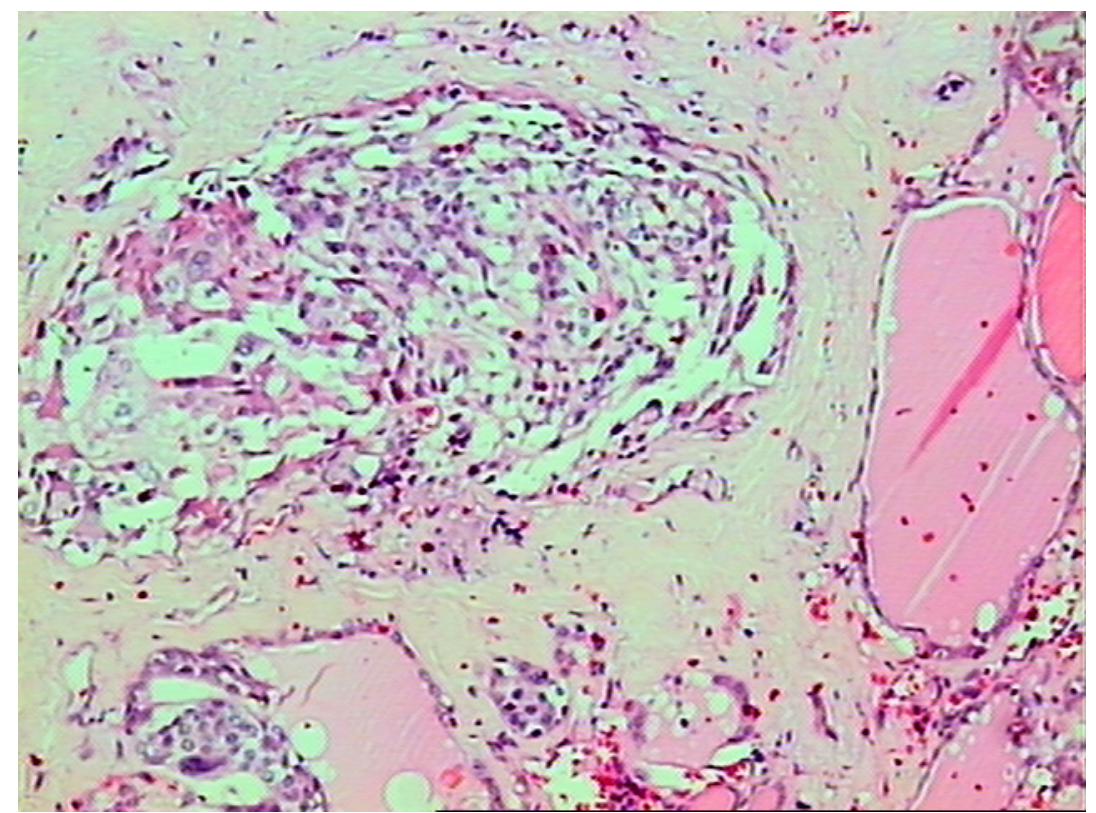

Figura 3- Caso 8. Corte histológico de tireóide em área de carcinoma medular, envolto por estroma fibroso denso. (HE 10X)

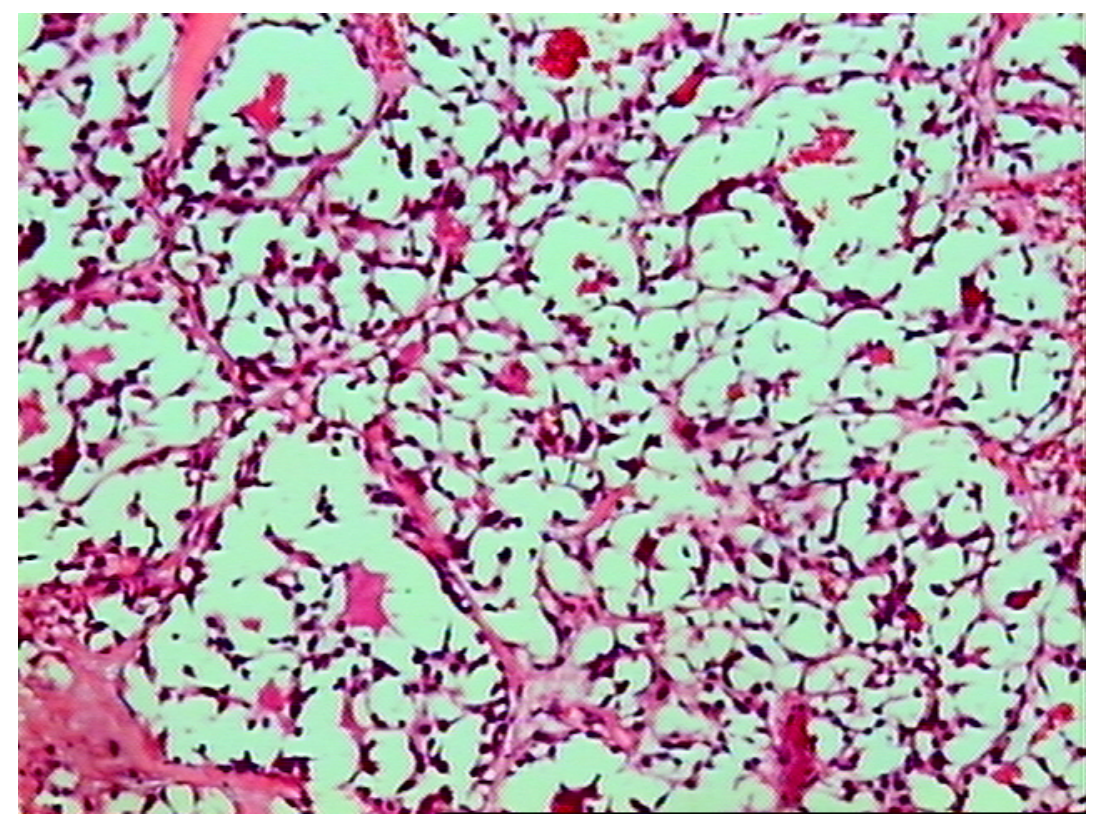

Figura 4- Caso 17. Corte histológico de linfonodo com metástase de carcinoma medular sólido de pequenas células. (HE 10X) 
Novamente, os espécimes teciduais selecionados, fixados em formalina a $10 \%$ e processados em parafina, foram seccionados (secções de $3 \mu \mathrm{m}$ ), acondicionados em lâminas através de Silane a 4\% (3-aminopropyl-triethoxy-silane, "Sigma", Saint Louis, EUA) e submetidos às colorações IH para MMP-2, MT1MMP e TIMP-2. As imunocolorações, para cada um dos reagentes, foram realizadas sobre cortes histológicos paralelos e seqüenciais para cada espécime estudado e por método de amplificação pelo complexo streptoavidina-biotina-peroxidase. ${ }^{158}$ Para a identificação da expressão IH de MMP-2 foi utilizado anticorpo monoclonal de camundongo, código MS-806 (“Labvision”, Fremont, EUA), para MT1-MMP foi utilizado anticorpo policlonal de coelho, código RB-1544 (“Labvision”, Fremont, EUA) e, para TIMP-2, anticorpo monoclonal de camundongo, código MS-1485 (“Labvision", Fremont, EUA). O anticorpo utilizado para MMP-2 proporcionou reações com as formas latente (pró-MMP-2) e ativa da enzima, segundo o fabricante.

Para desparafinização o conjunto de lâminas silanizadas foi colocado em suporte adequado e, posteriormente, as lâminas foram imersas em xilol e aquecidas em estufa entre $60^{\circ} \mathrm{C}$ e $65^{\circ} \mathrm{C}$, por 20 minutos. As lâminas receberam três banhos de xilol frio por um minuto, cada banho, e foram hidratadas em banhos de álcool absoluto, $95^{\circ}$ e $70^{\circ}$ seqüenciais por um minuto, lavadas em água corrente abundante, seguida de lavagem com água deionizada (destilada e sem íons).

A recuperação antigênica foi obtida por alta temperatura em vapor, para os marcadores MMP-2 e TIMP-2, em solução de Citrato, pH 6.0, por 50 minutos a 95 ${ }^{\circ} \mathrm{C}$ e por digestão enzimática em Tripsina ("Sigma”, Saint Louis, EUA), solução a 0,25\%, pH 7.8, por 10 minutos a $37^{\circ} \mathrm{C}$, para MT1-MMP. As lâminas foram resfriadas em temperatura ambiente por 20 minutos e lavadas em PBS ("phosphate- 
buffered saline" ou solução salina tamponada com fosfatos). Em seguida, foram imersas em PBS e permaneceram nesta solução tampão por cinco minutos, procedimento repetido mais duas vezes.

Após fase de hidratação, foi realizado bloqueio da peroxidase endógena com água oxigenada a 10 volumes, por cinco minutos, operação repetida por sete vezes. Posteriormente, as lâminas foram lavadas em água corrente abundante, lavadas em água deionizada e incubadas em PBS novamente. Antes da incubação do anticorpo primário (marcador), foi realizado bloqueio de proteínas através de "Protein Block Serum-Free”, código X909, (“DakoCytomation”, Carpinteria, EUA), por 15 minutos à temperatura ambiente, e realizados três banhos em PBS, de três minutos cada, e depois bloqueio de Avidina e Biotina com os "kits" "Dako Biotin Bloking", por 15 minutos, e "Dako Avidin Bloking" por 15 minutos também, com o objetivo de se reduzir marcações inespecíficas. As lâminas foram escorridas e mergulhadas em leite desnatado a $6 \%$, por 20 minutos.

Após os bloqueios, os anticorpos primários específicos nas diluições 1:700 para MMP-2 e 1: 40 para TIMP-2 foram acrescentados por 18 horas a $4{ }^{\circ} \mathrm{C}$ em câmera úmida. MT1-MMP foi fornecida sob forma pronta para uso, não necessitando de diluição.

As lâminas foram lavadas em PBS e incubadas em "kit" "LSAB Plus-HRP" ("Dako", Carpinteria, EUA), método da streptoavidina-biotina-peroxidase, composto de duas fases para amplificação dos sinais do anticorpo primário. Por uma hora, as lâminas receberam o anticorpo secundário, e, por 45 minutos, o complexo peroxidase conjugada. As lâminas foram lavadas em PBS e seguiu-se revelação pelo cromógeno 3-3` Diaminobenzidina (DAB) em "kit" "LiquidDAB + Substrate Chromogen 
System" ("DakoCytomation", Carpinteria, EUA). As lâminas foram lavadas abundantemente em água corrente e contracoradas com "Hematoxilina de Harris" (“Merck”, Darmstadt, Alemanha). Em seguida, as mesmas foram novamente lavadas em água corrente, desidratadas, diafanizadas em xilol e montadas com resina para microscopia com "Entellan" ("Merck", Darmstadt, Alemanha). O processo foi realizado no Laboratório de Imuno-histoquímica do Departamento de Patologia da Faculdade de Medicina da Universidade de São Paulo e no Laboratório de Investigações Médicas 02 (LIM 02) da mesma instituição.

A análise das imunorreações compreendeu toda a extensão das neoplasias representada nas lâminas, optando-se, para as reações com MT1-MMP e TIMP-2, por método semiquantitativo a partir do qual se considerou a porcentagem de células neoplásicas imunocoradas para cada espécime, bem como a intensidade da coloração observada (observação qualitativa). Da soma destes dois índices, obteve-se a pontuação final (“índice geral”) para cada caso, em relação a cada um dos marcadores empregados. Já, as reações com MMP-2 foram avaliadas, através de processo automatizado, por área de coloração no interior de cada representação tumoral, seguindo-se proporções (Tabela 2) diferentes das propostas para as reações com os outros dois marcadores (Tabela 3), uma vez que, para MMP-2, a imunocoloração deu-se no estroma da neoplasia, enquanto ocorreu nas células tumorais para os outros marcadores. A estimativa de intensidade de coloração para as reações com MMP-2 e o índice final foram realizados da mesma forma que para os outros dois marcadores imuno-histoquímicos (Tabela 3). As áreas de amilóide, acelulares, não foram incluídas na quantificação das imunocolorações, embora se tenha atentado à sua presença ou ausência nos espécimes. Como controle positivo 
para os três marcadores foi utilizado espécime de adenocarcinoma de cólon e, como controle interno positivo, foi utilizada imunocoloração das paredes vasculares tumorais, comumente intensa. Como controles negativos, os anticorpos primários foram substituídos por PBS nos preparados IH, em lâminas com espécimes de CMT sabidamente positivos às colorações com os marcadores.

As reações foram identificadas por coloração castanha, observada em diferentes intensidades, a depender do caso estudado, no citoplasma de células neoplásicas nos preparados para MT1-MMP e TIMP-2 e no estroma tumoral para MMP-2. Corresponderam à presença das proteínas em questão. O material relativo à metástase linfonodal do caso 8 não estava disponível e apenas o espécime tumoral primário foi submetido ao estudo IH proposto. Imunocolorações para espécimes de alguns casos não foram satisfatórias para um ou outro marcador, apesar de repetidos os processos de coloração IH. São os casos 9 e 18 (tumores primários) para MT1MMP, casos 5, 9 e 23 (tumores primários) para TIMP-2, caso 14 (metástase linfonodal) e caso 37 (tumor primário e metástase) para MMP-2.

Tabela 2 - Índice para quantificação de área tumoral imunocorada por MMP-2

\begin{tabular}{c|c}
\hline $\begin{array}{c}\text { PROPORÇÃO DE ÁREA NEOPLÁSICA IMUNOCORADA - MMP-2 } \\
(\%)\end{array}$ & ÍNDICE \\
\hline 0 & 0 \\
$<1$ & 1 \\
$\geq 1 \mathrm{e}<2$ & 2 \\
$\geq 2$ & 3 \\
\hline
\end{tabular}


Tabela 3 - Índices para análises semiquantitativa e qualitativa das imunocolorações: porcentagem de células neoplásicas coradas (MT1MMP e TIMP-2); intensidade de coloração e pontuação final, resultado da soma dos pontos da proporção de células ou área imunocoradas e intensidades de coloração (MMP-2, MT1-MMP e TIMP-2)

\begin{tabular}{c|cccc}
\hline $\begin{array}{c}\text { PROPORÇÃO DE } \\
\text { CÉLULAS } \\
\text { IMUNOCORADAS (\%) }\end{array}$ & ÍNDICE & & $\begin{array}{c}\text { INTENSIDADE DE } \\
\text { IMUNOCOLORAÇÃO }\end{array}$ & ÍNDICE \\
\cline { 5 - 5 } & 0 & & Fraca & 1 \\
\cline { 5 - 5 }$<25$ & 1 & Moderada & 2 \\
$\geq 25 \mathrm{e}<50$ & 2 & & 3 \\
$\geq 50$ & 3 & &
\end{tabular}

\begin{tabular}{c|c}
\hline $\begin{array}{c}\text { PONTUAÇÃO FINAL } \\
\text { (proporção de células ou } \\
\text { área coradas + intensidade } \\
\text { da coloração) }\end{array}$ & ÍNDICE GERAL \\
\hline $0-2$ & 1 \\
$3-4$ & 2 \\
$5-6$ & 3
\end{tabular}

NOTA: Para as reações com MMP-2 não foram contabilizadas as porcentagens de células tumorais coradas, mas sim a área de coloração no estroma neoplásico e aplicado índice de pontuação final semelhante.

As lâminas tratadas com MMP-2 foram estudadas através de microscópio de luz "Zeiss" em aumento de 10X, sendo a avaliação de área corada realizada com auxílio de Sistema Analisador de Imagem (“Kontron Eletronic 300”, “Zeiss”). A estação de trabalho consistiu de microscópio trinocular, vídeo-câmera colorida (“SONY CCD” - Iris) com placa digitalizadora de imagens e microcomputador com processador "Pentium" $133 \mathrm{MHz}$, "IBM-PC" compatível, operando em ambiente "Windows-95". As imagens obtidas foram digitalizadas com auxílio do "software", proporcionando possibilidade de compartilhamento de dados com planilha eletrônica ("Microsoft Excel"), além de análise e interpretação dos dados de mensuração. Após 
aquisição de imagem através da câmera, utilizou-se recurso de "threeshold" para marcação das estruturas a serem quantificadas. O cálculo de proporção de área positiva para o marcador foi realizado através de sua quantificação, seguida de determinação de área total de tecido por campo, através de ferramenta de traço livre do Programa Analisador de Imagem “Kontron”. Já, a determinação da intensidade da reação foi realizada em função do observado para a maioria da área imunomarcada para cada caso, tendo-se como controle interno a imunocoloração dos vasos sanguíneos neoplásicos. $\mathrm{O}$ procedimento caracterizou-se por rotina semiautomatizada, seguida de arquivamento dos dados coletados em planilha "Microsoft Excel”. Para as outras duas colorações, o aumento ótico utilizado para as análises do material foi de 40X e, o processo de leitura, manual, não-automatizado. Os dados também foram coletados em planilha "Microsoft Excel".

As áreas foliculares não-patológicas não foram analisadas nos estudos das imunocolorações, uma vez que muitos tumores eram extensos e comprometiam grande parte do parênquima glandular. Não foi possível, também, determinar se os segmentos neoplásicos estudados faziam parte da periferia ou de porções centrais da neoplasia, especialmente quando esta ocupava todo o bloco incluso em parafina.

As lâminas foram lidas por um único observador (Prof ${ }^{\mathrm{a}}$. Dr ${ }^{\mathrm{a}}$. Consuelo Junqueira Rodrigues - Laboratório de Investigações Médicas 02), patologista sem conhecimento das particularidades dos casos. As Figuras 5, 6 e 7 exibem exemplos de cortes histológicos de espécimes tumorais primários de CMT corados por MT1MMP, TIMP-2 e MMP-2, respectivamente, através de técnica IH descrita. As Figuras 8, 9 e 10 exibem exemplos de cortes histológicos de espécimes metastáticos linfonodais, também corados por MT1-MMP, TIMP-2 e MMP-2, respectivamente. A 
Figura 11 exemplifica a marcação da imunocoloração pesquisada (MMP-2) através do Sistema Analisador de Imagem. A área demarcada em verde representa a área reagente à MMP-2 e sua quantificação é realizada através do "software" citado.

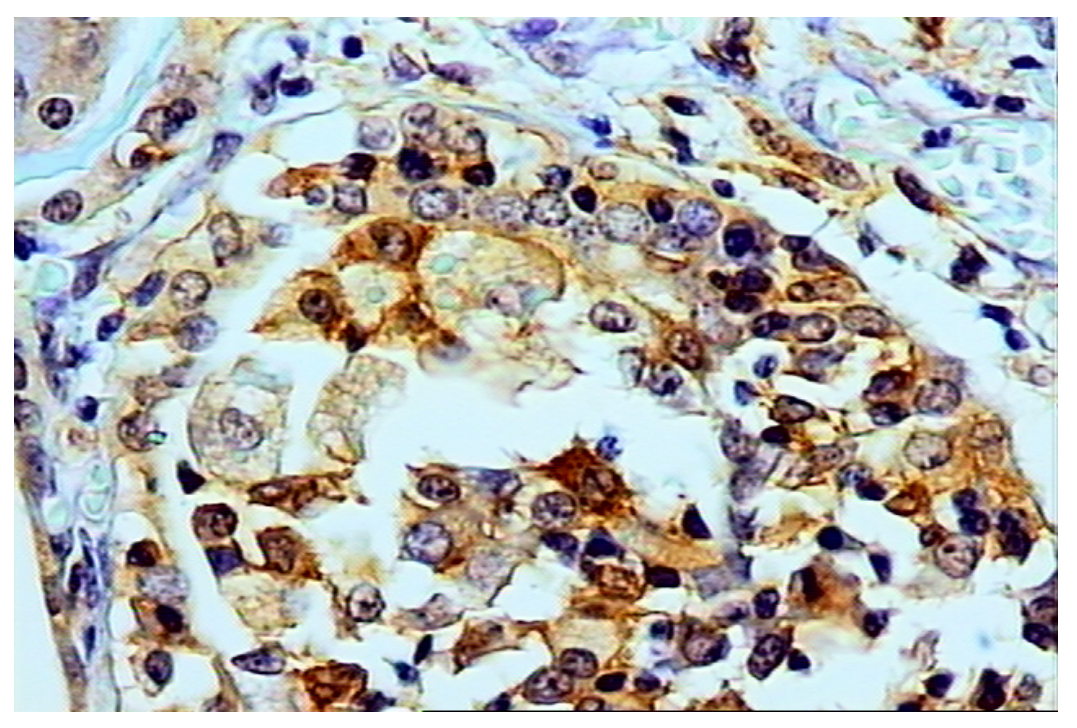

Figura 5- Caso 8. Corte histológico de carcinoma medular da tireóide, primário, submetido à imunorreação para MT1-MMP. Notar reação positiva (cor marrom) no citoplasma das células tumorais. (IH 40X)

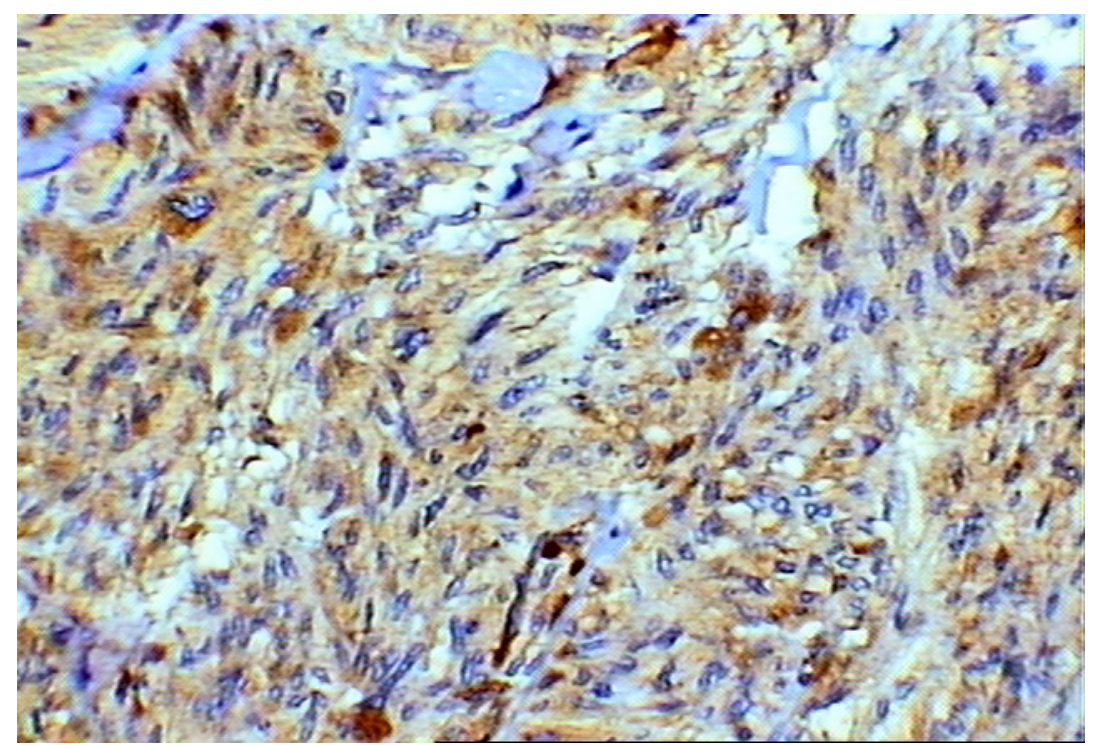

Figura 6- Caso 10. Corte histológico de carcinoma medular da tireóide, primário, submetido à imunorreação para TIMP2. Notar reação positiva (cor marrom) no citoplasma das células neoplásicas. (IH 20X) 


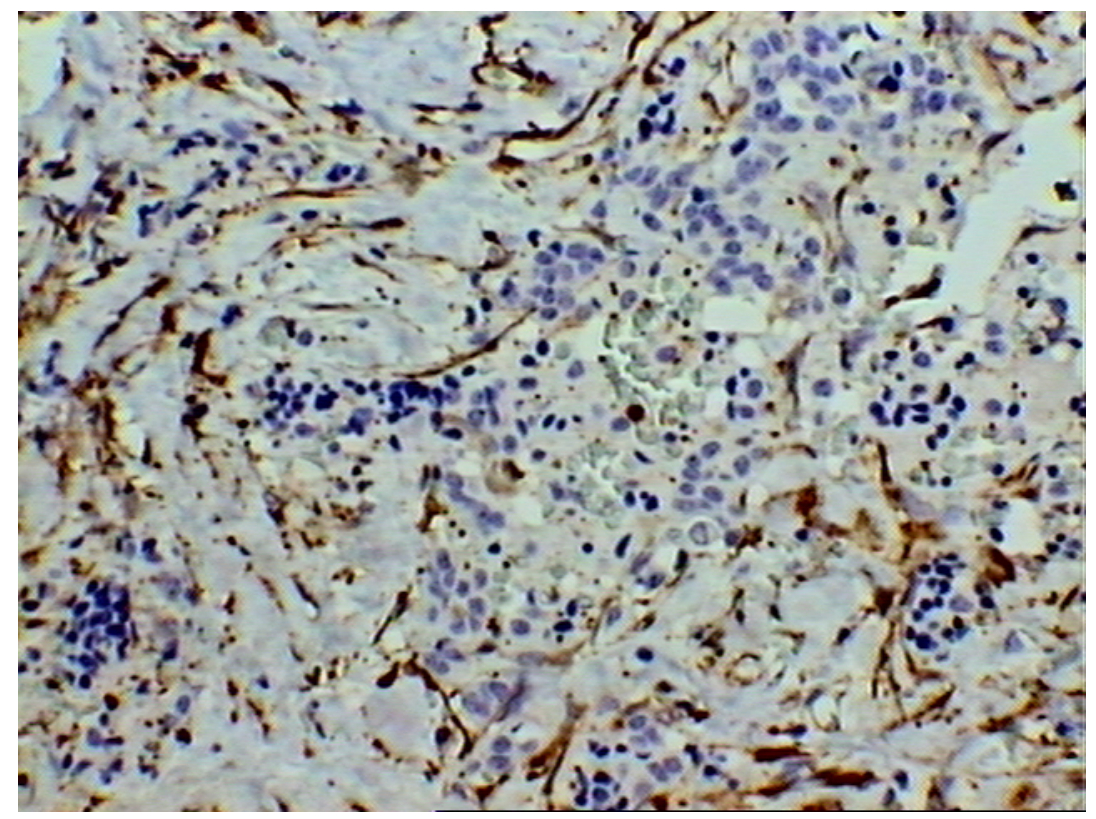

Figura 7- Caso 8. Corte histológico de carcinoma medular da tireóide, primário, submetido à imunorreação para MMP2. Notar reação positiva (cor marrom) no estroma neoplásico. (IH 20X)

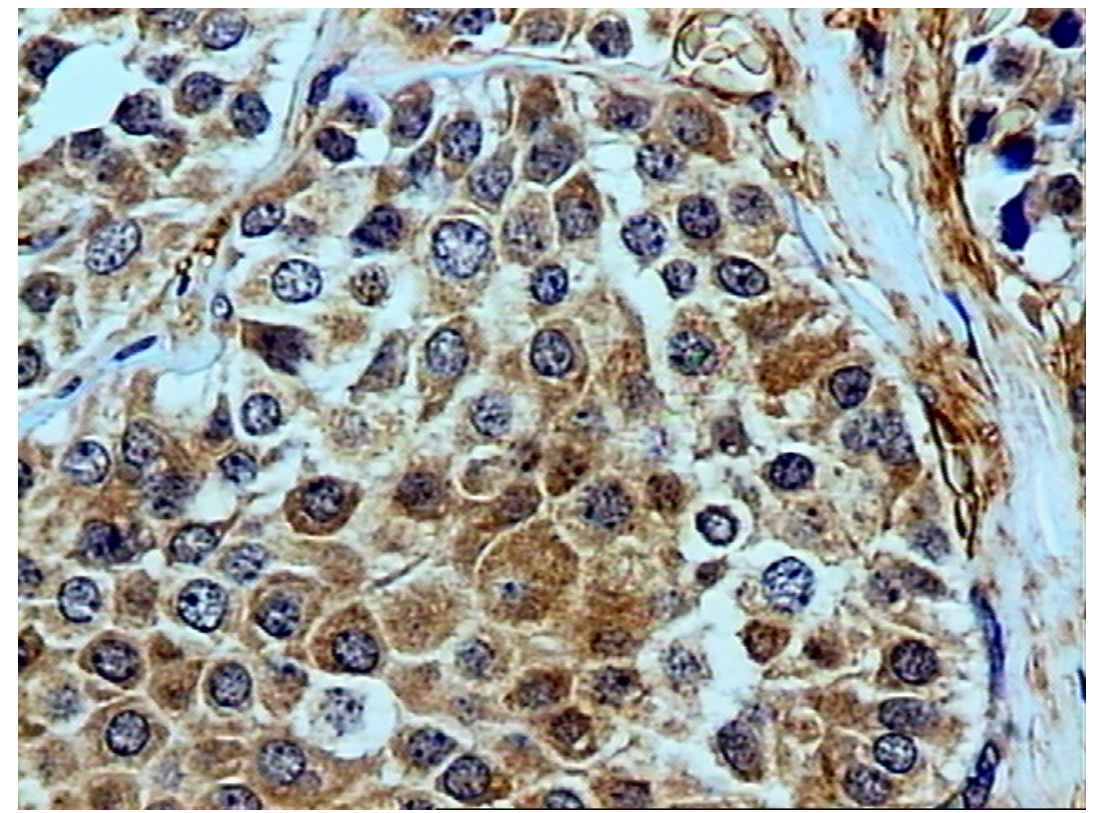

Figura 8- Caso 12. Corte histológico de linfonodo com metástase de carcinoma medular submetido à imunorreação para MT1-MMP. Notar reação positiva (cor marrom) no citoplasma das células tumorais. (IH 40X) 


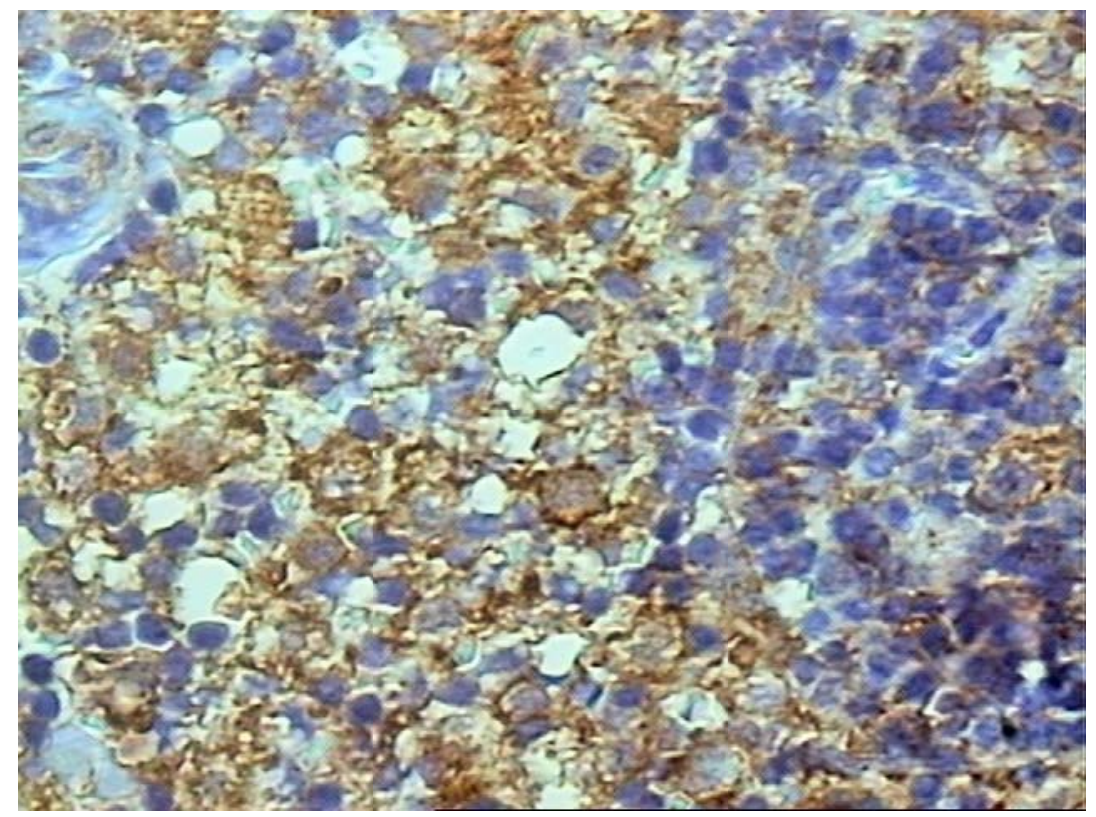

Figura 9- $\quad$ Caso 35. Corte histológico de linfonodo com metástase de carcinoma medular submetido à imunorreação para TIMP-2. Notar reação positiva (cor marrom) no citoplasma das células tumorais. (IH 40X)

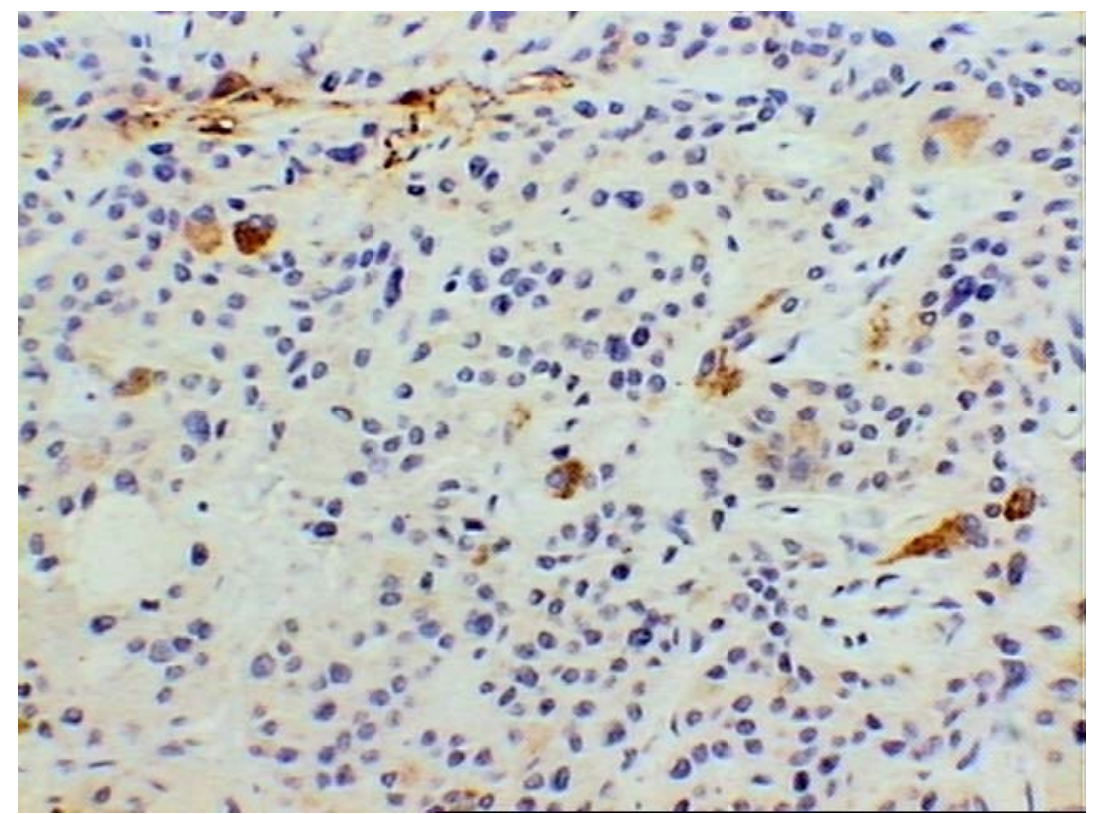

Figura 10- Caso 12. Corte histológico de linfonodo com metástase de carcinoma medular submetido à imunorreação para MMP-2. Notar reação positiva (cor marrom) no estroma neoplásico. (IH 20X) 


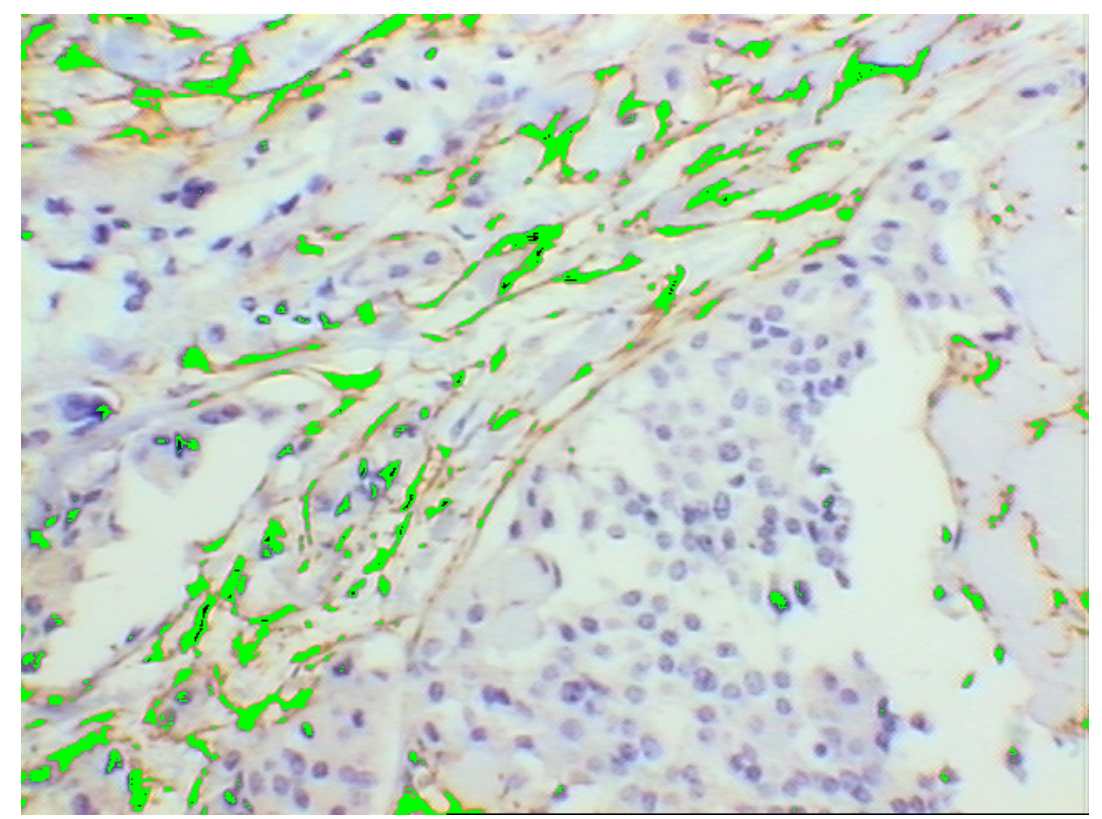

Figura 11- Campo microscópico de CMT primário observado com objetiva de 20X e ocular de 10X. Marcação de imunorreação para MMP2 (em verde) no estroma do tumor, utilizando-se Sistema Analizador de Imagem

\subsection{ANÁLISE ESTATÍSTICA}

Para análise estatística dos dados foram obtidas distribuições absolutas e percentuais, uni e bivariadas, para as variáveis nominais ou de categorias, e, para as variáveis numéricas, medidas estatísticas tais como valor mínimo, valor máximo, média, desvio padrão, mediana e curvas de Kaplan Meier para probabilidades de sobrevida e tempo livre de doença (técnicas para estatística descritiva). Como técnicas de estatística inferencial, foram utilizados o teste Qui-quadrado de independência, o teste Exato de Fisher, quando as condições para utilização do teste 
Qui-quadrado não foram verificadas, e o teste F (análise de variância - ANOVA) para comparação entre mais de duas categorias, bem como o teste t-Student para variâncias iguais ou desiguais, conforme resultados de verificação de hipótese de igualdade de variâncias. O teste de igualdade de variâncias foi realizado através do teste $\mathrm{F}$ para a finalidade específica.

Ressalta-se que no caso do estudo de ocorrência de doença (persistência ou recidiva neoplásicas e cura) foram obtidos valores de risco relativo considerando-se a categoria com menor incidência como base.

A margem de erro utilizada para a decisão dos testes estatísticos foi de 5,0\% (valor de $\mathrm{p} \leq 0,05$ ).

Os dados foram digitados em planilha "Excel" e os programas utilizados para obtenção dos cálculos estatísticos foram o SAS ("Statistical Analysis System”, "SAS Institute Inc.", Cory, EUA) na versão 8.0 e o SPSS ("Statistical Package for the Social Sciences”, “SPSS Inc.”, Chicago, EUA) na versão 11. 
5 RESULTADOS 


\section{RESULTADOS}

\subsection{CARACTERIZAÇÃO DOS CASOS}

Foram revistos 37 pacientes que tinham, ao diagnóstico de CMT, entre nove e 65 anos completos de vida. Média etária foi calculada em 33, 24 anos, com desvio padrão de 14,82 anos, coeficiente de variação calculado em 44,58\% e mediana de 33 anos. Foram agrupados em cinco faixas etárias, demonstradas na Tabela 4, juntamente com caracterização de gênero.

Tabela 4 - Distribuição dos pacientes segundo faixa etária (em anos completos) e gênero

\begin{tabular}{|c|c|c|}
\hline & $\mathrm{N}$ & $\%$ \\
\hline \multicolumn{3}{|c|}{ • Faixa etária (em anos) } \\
\hline A - Até 20 & 10 & 27,0 \\
\hline B - 21 a 30 & 6 & 16,2 \\
\hline$C-31$ a 40 & 7 & 18,9 \\
\hline D - 41 a 50 & 10 & 27,0 \\
\hline E - 51 ou mais & 4 & 10,8 \\
\hline TOTAL & 37 & 100,0 \\
\hline \multicolumn{3}{|l|}{ • Gênero } \\
\hline Feminino & 24 & 64,9 \\
\hline Masculino & 13 & 35,1 \\
\hline TOTAL & 37 & 100,0 \\
\hline
\end{tabular}

Em 27 pacientes (73\%), o diagnóstico de CMT foi realizado em momento anterior ao tratamento operatório, sendo em 13 através de programas de rastreamento 
e, em três, através de USG cervical em exames de rotina. Os carcinomas dos demais 10 pacientes foram diagnosticados durante o tratamento cirúrgico, através de exame anatomopatológico de congelação, ou no pós-operatório, por exame anatomopatológico, após inclusão da peça em parafina. Ao diagnóstico, 28 pacientes (75,7\%) apresentavam nódulos tireóideos palpáveis ao exame físico, sendo que nove (24,3\%) já eram também portadores de adenomegalias metastáticas cervicais, palpáveis. Dois pacientes não tinham nódulos tireóideos palpáveis, mas já apresentavam adenomegalias metastáticas. Dados apresentados na Tabela 5.

Tabela 5 - Distribuição dos pacientes segundo as variáveis: diagnóstico préoperatório, como achado acidental de USG e por rastreamento; exame físico compatível com presença de nódulos tireóideos e/ou adenomegalia cervical metastática e presença de sintomas sistêmicos ao diagnóstico

\begin{tabular}{l|c|c}
\hline \multicolumn{1}{c|}{ VARIÁVEL } & $\mathrm{N}$ & $\%$ \\
\hline • Diagnóstico pré-operatório & 27 & 73,0 \\
Sim & 10 & 27,0 \\
Não & 37 & 100,0 \\
TOTAL & 3 & \\
• Diagnóstico como achado acidental de USG & 34,1 \\
Sim & 34 & 91,9 \\
Não & 37 & 100,0 \\
TOTAL & & \\
• Diagnóstico por rastreamento & 13 & 35,1 \\
Sim & 24 & 64,9 \\
Não & 37 & 100,0 \\
TOTAL & & \\
• Exame físico cervical positivo & 30 & 81,1 \\
Sim & 7 & 18,9 \\
Não & 37 & 100,0 \\
TOTAL & \multicolumn{2}{c}{} \\
• Sintomas sistêmicos & 7 & 18,9 \\
Sim & 30 & 81,1 \\
Não & 37 & 100,0 \\
\hline TOTAL & &
\end{tabular}

NOTA: N refere-se ao número de pacientes. 
Trinta e dois pacientes foram submetidos à tireoidectomia total no primeiro tempo operatório e dois, cujas lesões foram consideradas irressecáveis, sofreram apenas tireoidectomias parciais (casos 8 e 24). Os três restantes foram submetidos à complementação da tireoidectomia em segundo tempo cirúrgico. Seis pacientes não foram submetidos a tratamento das cadeias linfonodais cervicais, sendo quatro deles diagnosticados por rastreamento (NEM2A) e dois casos esporádicos. Entre os pacientes rastreados, três, de nove, 14 e 16 anos, não foram submetidos à linfadenectomia cervical por portarem tumores primários considerados pequenos (6 mm, 5 mm e $1 \mathrm{~mm}$ de diâmetro, respectivamente) e calcitonemias basais dentro dos limites da normalidade. A quarta paciente, de 26 anos ao diagnóstico, apesar de rastreada, já era portadora de doença inoperável e, inclusive, faleceu (caso 8). Entre os dois casos esporádicos não submetidos ao esvaziamento cervical, um não pode ser adequadamente estadiado, por não contar com as medidas de seu tumor primário. Calcitonemia encontrava-se dentro dos limites da normalidade após quatro meses da tireoidectomia total e assim permaneceu por 189 meses (caso 3). O outro paciente (caso 9), apesar de portar tumor estadiado como T3, curou-se e manteve seguimento ambulatorial por 67 meses.

Três pacientes $(8,1 \%)$ foram submetidos somente ao esvaziamento do compartimento central, seis $(16,2 \%)$ aos esvaziamentos dos compartimentos central e lateral (um lado), 19 (51,4\%) aos esvaziamentos central e lateral bilateral e, três, ao esvaziamento dos compartimentos laterais, bilateralmente, sem linfadenectomia central. As razões para tais condutas não foram especificadas nos prontuários dos pacientes. 
Os tumores primários também foram agrupados em faixas, segundo seus maiores diâmetros. Dados demonstrados na Tabela 6, juntamente com outras informações anatomopatológicas.

Um paciente portava foco de carcinoma papilífero concomitante ao CMT, em cinco foi observada concomitância de bócio e, em cinco outros indivíduos, presença de tireoidite de Hashimoto.

Tabela 6 - Distribuição dos pacientes segundo as variáveis: faixa de maior diâmetro $(\mathrm{mm})$ e multicentricidade tumorais, extensão neoplásica para a cápsula tireóidea, extensão neoplásica para tecidos adjacentes, invasão neoplásica vascular e presenças de HCC e amilóide

\begin{tabular}{|c|c|c|}
\hline VARIÁVEL & $\mathrm{N}$ & $\%$ \\
\hline \multicolumn{3}{|l|}{ - Faixa de maior diâmetro tumoral (em mm) } \\
\hline A - Até 5 & 3 & 8,6 \\
\hline $\mathrm{B}->5$ e $<$ que 15 & 9 & 25,7 \\
\hline $\mathrm{C}-\geq 15$ e $<$ que 30 & 10 & 28,6 \\
\hline $\mathrm{D}-\geq 30$ & 13 & 37,1 \\
\hline TOTAL $^{(1)}$ & 35 & 100,0 \\
\hline \multicolumn{3}{|l|}{ - Multicentricidade tumoral } \\
\hline Sim & 21 & 60,0 \\
\hline Não & 14 & 40,0 \\
\hline TOTAL $^{(2)}$ & 35 & 100,0 \\
\hline \multicolumn{3}{|l|}{ • Extensão para cápsula tireóidea } \\
\hline Sim & 13 & 35,1 \\
\hline Não & 24 & 64,9 \\
\hline TOTAL & 37 & 100,0 \\
\hline \multicolumn{3}{|l|}{ • Extensão para tecidos adjacentes } \\
\hline $\operatorname{Sim}$ & 5 & 13,5 \\
\hline Não & 32 & 86,5 \\
\hline TOTAL & 37 & 100,0 \\
\hline \multicolumn{3}{|l|}{ • Invasão vascular } \\
\hline Sim & 9 & 40,9 \\
\hline Não & 13 & 59,1 \\
\hline TOTAL $^{(3)}$ & 22 & 100,0 \\
\hline
\end{tabular}




\section{Conclusão - Tabela 6}

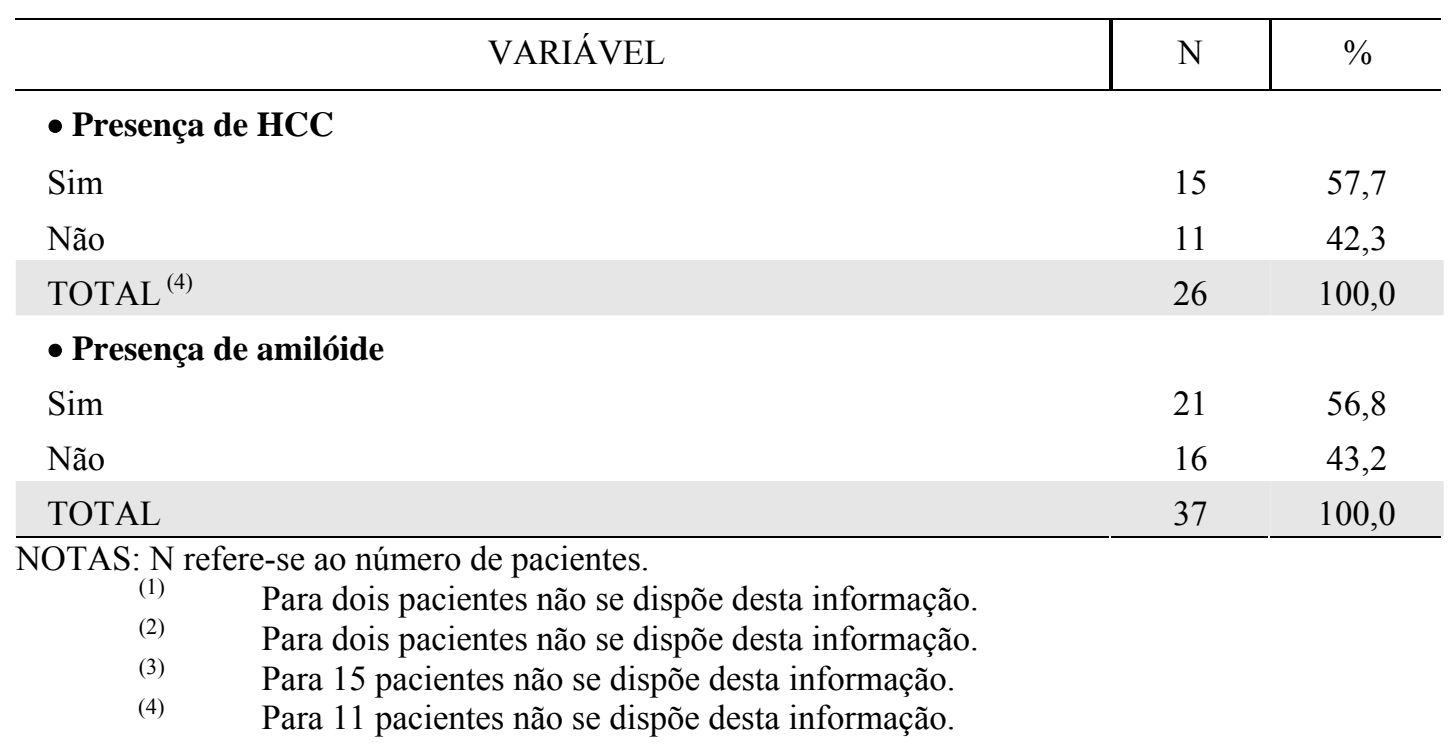

Entre $21(56,8 \%)$ portadores de metástases linfonodais cervicais, três as apresentavam somente no compartimento central cervical, enquanto que quatro as apresentavam somente nos compartimentos laterais, segundo laudos anatomopatológicos. Os demais continham linfonodos acometidos pela neoplasia tanto no compartimento central, como em níveis laterais. Em 10 casos $(47,6 \%$ destes 21) as metástases estendiam-se além dos limites linfonodais. Apenas um indivíduo teve diagnóstico de metástases distantes à determinação do CMT, no entanto notouse que os pacientes, em geral, não eram submetidos a exames de imagem de corpo inteiro, ao diagnóstico da neoplasia primária, como busca ativa de metástases a distância.

O estadiamento TNM para cada paciente está demonstrado no ANEXO C, juntamente com todos os dados aqui descritos. Nove pacientes foram classificados como Estádio I, quatro como Estádio II, quatro como Estádio III, 17 como Estádio IV A, um como Estádio IV $\mathrm{C}$ e dois não puderam ser estadiados por indisponibilidade de dados necessários para tal. Dados relativos às presenças de 
acometimento linfonodal e metastático a distância, além de extensão capsular linfonodal e estádio, estão representados na Tabela 7.

Tabela 7 - Distribuição dos pacientes segundo as variáveis: presença de linfonodos acometidos pela neoplasia, extensão capsular linfonodal, metástases a distância ao diagnóstico etiológico e estádio patológico (TNM)

\begin{tabular}{l|c|c}
\hline \multicolumn{1}{c|}{ VARIÁVEL } & $\mathrm{N}$ & $\%$ \\
\hline - Metástases linfonodais cervicais & & \\
Sim & 21 & 56,8 \\
Não & 16 & 43,2 \\
TOTAL & 37 & 100,0
\end{tabular}

- Extensão capsular linfonodal

$\begin{array}{lcc}\text { Sim } & 10 & 47,6 \\ \text { Não } & 11 & 52,4 \\ \text { TOTAL } & 21 & 100,0\end{array}$

- Metástases a distância

Sim $\quad 1 \quad 2,7$

Não $\quad 36 \quad 97,3$

$\begin{array}{lll}\text { TOTAL } & 37 & 100,0\end{array}$

- Estádio TNM

$\begin{array}{llll}\text { I } & 9 & 25,7\end{array}$

II $\quad 4 \quad 11,4$

III $\quad 4 \quad 11,4$

$\begin{array}{lll}\text { IV A } & 17 & 48,6\end{array}$

$\begin{array}{lll}\text { IV C } & 1 & 2,9\end{array}$

TOTAL $^{(1)} \quad 35 \quad 100,0$

NOTAS: N refere-se ao número de pacientes.

(1) Para dois pesquisados não se dispõe desta informação.

Entre os pacientes estudados, 21 eram casos esporádicos (56,8\%), 15 portadores de CMTs vinculados à NEM2A (40,5\%) e, um, de CMT vinculado à NEM2B (2,7\%) (Tabela 8). Nenhum apresentava a forma familiar isolada da neoplasia. Presença de feocromocitoma foi observada em três pacientes, sendo que dois também contaram com diagnóstico de HPT, por hiperplasia e adenoma de paratireóides em um paciente e somente adenoma em outro. HPT também foi 
observado em outro indivíduo, por adenoma de paratireóide e uma paciente, portadora de NEM2A, relatava antecedente de litíase em vias urinárias, apesar das dosagens de paratormônio humano e cálcio séricos estarem dentro dos limites da normalidade.

O único paciente NEM2B (caso 37) foi assim classificado por contar com mutação no códon 918 do RET proto-oncogene. Estava com 10 anos de idade ao diagnóstico de CMT, realizado no intra-operatório, foi submetido à tireoidectomia total e à linfadenectomia dos três compartimentos cervicais e estadiado como IV A (T3N1bM0). Permanecia com calcitonemia elevada (cinco vezes o máximo valor de referência), passados quatro meses da operação com intenção curativa, mas sem evidências clínicas ou imagenológicas de doença residual cervical ou metastática. Provém de família grande sem nenhum caso relatado de CMT, mas também sem nenhuma investigação laboratorial conduzida até o final deste trabalho. Foi considerado, a princípio, como portador de mutação nova.

Tabela 8 - Distribuição dos pacientes segundo as variáveis: CMT-E, CMTNEM2A e CMT-NEM2B

\begin{tabular}{lc|c|c}
\hline & VARIÁVEL & $\mathrm{N}$ & $\%$ \\
\hline - CMT-E & & 21 & 56,8 \\
- CMT-NEM2A & & 15 & 40,5 \\
- CMT-NEM2B & 1 & 2,7 \\
TOTAL & 37 & 100,0 \\
\hline
\end{tabular}

NOTA: $\mathrm{N}$ refere-se ao número de pacientes.

Dosagens séricas de CT no momento do diagnóstico de CMT, ou até o pósoperatório imediato, não foram notificadas para onze pacientes, assim como também não o foram os títulos séricos de CEA para 19 pacientes da amostra. Para os 26 pacientes que contaram com dosagens de calcitonina entre os períodos pré ou pós- 
operatório imediato, tais valores foram calculados em 138,6 vezes, em média, o máximo valor laboratorial de referência, variando de títulos normais a 2240 vezes (desvio padrão calculado em 440,52 - teste t-Student e mediana em 17,29) (Tabela 9). Valores séricos de CEA, por sua vez, variaram de títulos dentro dos limites da normalidade até 58,8 vezes o máximo valor de referência (média de 10,58, desvio padrão 16,08 - teste t-Student e mediana igual a 2,24, calculados para os valores referentes aos títulos séricos de 18 pacientes) (Tabela 10).

Vinte pacientes $(54,1 \%)$ foram considerados curados após o tratamento cirúrgico inicial, por evoluírem assintomáticos e com títulos séricos de CT e CEA dentro dos limites da normalidade. Não foram obtidas informações sobre as dosagens séricas evolutivas de CEA de dois pacientes tidos como curados e somente seis foram submetidos a testes provocativos para CT, como confirmação de cura bioquímica. Oito dos pacientes, tidos inicialmente como curados, não apresentavam registros de dosagens de $\mathrm{CT}$ ao diagnóstico do carcinoma ou até o pós-operatório imediato. Três apresentavam dosagens basais normais e, os demais, dosagens 1,64; 1,$66 ; 3,5 ; 3,76 ; 5,65 ; 17,2 ; 28,6 ; 31,42$ e 68,4 vezes o maior limite de referência. Onze não apresentavam registros de dosagens de CEA ao diagnóstico de CMT ou até o pós-operatório imediato. Quatro apresentavam títulos normais e, os demais, dosagens 2,$18 ; 2,29 ; 5,48 ; 16,66$ e 23,52 vezes o maior limite de referência. O tempo entre operação e cura foi notificado para 15 pacientes, sendo imediato (menor que um mês) em quatro casos, de um mês para outros quatro casos, de dois a quatro meses para cinco, de sete meses para um paciente e de oito meses para outro. Média, desvio padrão e mediana foram respectivamente 2,33 meses, 2,53 meses e um mês. Cinco pacientes evoluíram com recidivas neoplásicas (Tabela 9). 
Tabela 9 - Distribuição dos pacientes segundo as variáveis: valores relativos de $\mathrm{CT}$ ao diagnóstico ou pós-operatório imediato (inicial) e durante o seguimento clínico (quantas vezes maiores que o máximo valor de referência laboratorial), evolução clínica, tempo para cura após operação (em meses completos) e recidiva bioquímica

\begin{tabular}{l|cc}
\hline \multicolumn{1}{c|}{ VARIÁVEL } & $\mathrm{N}$ & $\%$ \\
\hline - Número de vezes de aumento de CT em relação ao & & \\
valor máximo de referência (inicial) & & \\
Normal & 3 & 11,5 \\
$>1$ a 3 vezes & 2 & 7,7 \\
>10 a 30 vezes & 7 & 27,0 \\
$>30$ a 100 vezes & 5 & 19,2 \\
$>100$ vezes & 4 & 15,4 \\
TOTAL $^{(1)}$ & 26 & 100,0
\end{tabular}

- Número de vezes de aumento de CT em relação ao valor máximo de referência (valores máximos em seguimento pós-operatório)

Normal

$>3$ a 10 vezes

$15 \quad 41,7$

$>10$ a 30 vezes

$4 \quad 11,1$

$>50$ a 100 vezes

$4 \quad 11,1$

$>100$ vezes

25,5

TOTAL $^{(2)}$

- Evolução clínica inicial

Cura

Persistência

- Tempo para cura após operação (em meses)

Imediata (menor que um mês)

1 a 2

3 a 4

5 a 8

TOTAL $^{(3)}$

\section{- Recidiva bioquímica (entre os inicialmente curados)}

\begin{tabular}{lcc} 
Sim & 5 & 25,0 \\
Não & 15 & 75,0 \\
TOTAL & 20 & 100,0 \\
\hline
\end{tabular}

NOTAS: N refere-se ao número de pacientes.

(1) Para 11 pacientes não se dispõe desta informação.

(2) Para um paciente não se dispõe desta informação.

(3) Para cinco pacientes não se dispõe desta informação e 17 não tiveram cura. 
Tabela 10 - Distribuição dos pacientes segundo as variáveis relacionadas às dosagens séricas de CEA: à época do diagnóstico ou pós-operatório imediato (quantas vezes maiores que o máximo valor de referência laboratorial), se dentro dos limites da normalidade, ou não, durante o seguimento clínico e se elevadas junto à progressão da doença

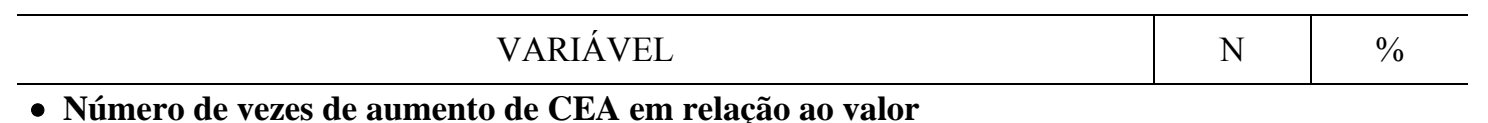

- Número de vezes de aumento de CEA em relação ao valor máximo de referência (inicial)

Normal

$6 \quad 33,3$

$>1$ a 3 vezes

$4 \quad 22,2$

$>3$ a 10 vezes

$3 \quad 16,7$

$>10$ vezes

$5 \quad 27,8$

TOTAL $^{(1)}$

$18 \quad 100,0$

- Títulos de CEA inferiores ao máximo valor de referência (seguimento)

$\begin{array}{lrc}\text { Sim } & 22 & 68,7 \\ \text { Não } & 10 & 31,3 \\ \text { TOTAL }^{(2)} & 32 & 100,0\end{array}$

- CEA elevado junto à progressão da doença

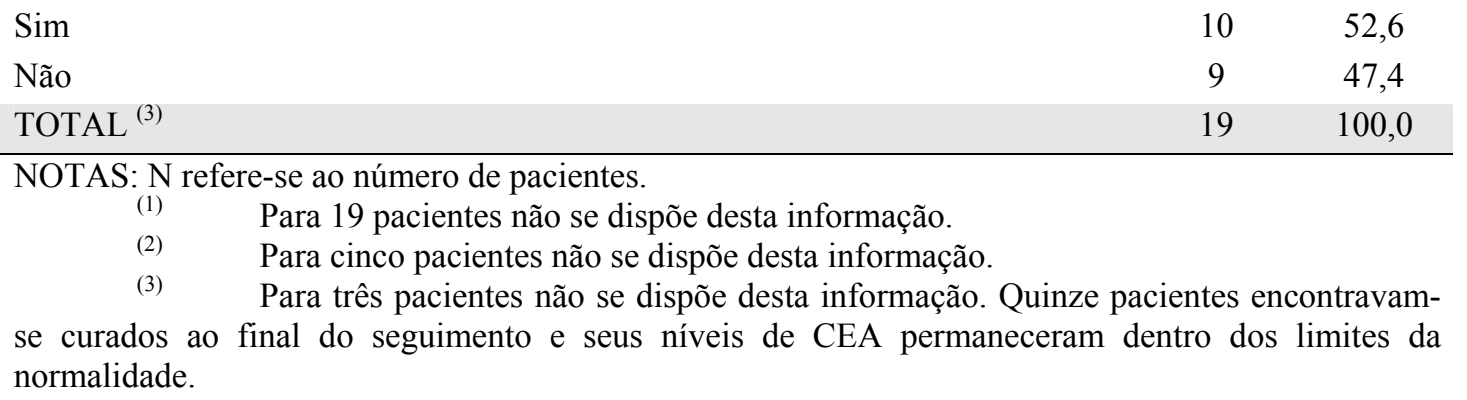

Entre os pacientes submetidos a dosagens séricas de CEA durante seus seguimentos, vinte e dois evoluíram com títulos inferiores aos máximos limites de referência (Tabela 10), apesar de persistência neoplásica em seis e recidivas em três deles. Os 10 pacientes que mantiveram títulos elevados de CEA durante suas evoluções o fizeram em vigência de doença ativa.

A Tabela 11 resume a distribuição dos pacientes que não obtiveram cura, segundo sua evolução clínica, até o momento final da pesquisa. 
Tabela 11 - Distribuição dos pacientes que não obtiveram cura, segundo sua evolução clínica

\begin{tabular}{l|c|c}
\hline \multicolumn{1}{c|}{ VARIÁVEL } & N & $\%$ \\
\hline - Evolução clínica & 5 & 22,7 \\
Só doença cervical (evidências clínicas ou imagenológicas) & 1 & 4,5 \\
Só metástase a distância (evidências clínicas ou imagenológicas) & 6 & 27,3 \\
Doença cervical e metástase à distância (evidências clínicas ou imagenológicas) & 10 & 45,5 \\
Sem evidências de doença cervical ou distante apesar do aumento de CT sérica & 22 & 100,0 \\
\hline TOTAL & &
\end{tabular}

\subsubsection{FORMAS DA DOENÇA}

Vinte e um pacientes foram caracterizados como casos esporádicos e suas idades variaram de 16 a 65 anos completos (média de 42 anos, desvio padrão 12,21 teste t-Student). Quatorze $(66,7 \%$ destes 21$)$ eram mulheres e em $12(57,1 \%)$ o diagnóstico de CMT foi anterior à operação inicial. Nódulos tireóideos já eram palpáveis ao exame físico de 12 pacientes $(57,1 \%)$, sendo que em outros seis palpavam-se também adenomegalias metastáticas e, em um, somente adenomegalias.

Os maiores diâmetros neoplásicos variaram de $6 \mathrm{~mm}$ ao acometimento de toda a glândula, sendo que em seis casos $(28,6 \%)$ foram observadas áreas de invasão capsular e, em dois casos $(9,5 \%)$, franca invasão de estruturas adjacentes à tireóide. Acometimento linfonodal cervical foi observado em 12 pacientes $(57,1 \%)$, após análise anatomopatológica de seus produtos operatórios. Apenas um paciente apresentava metástases a distância ao diagnóstico. Três pacientes foram classificados como Estádio I, três como Estádio II, três como estádio III, nove como Estádio IV A 
e um como Estádio IV C. Dezessete haviam sido submetidos à tireoidectomia total inicial e somente dois não foram submetidos a nenhum tipo de linfadenectomia cervical, sendo clinicamente caracterizados como N0.

Os valores iniciais das calcitonemias basais variaram de 1,66 a 2240 vezes a máxima referência laboratorial, com média calculada em 249,08, desvio padrão em 613,21, segundo teste t-Student. Os valores séricos de CEA variaram de títulos normais a 23,5 vezes o máximo valor de referência, com média de 8,62 e desvio padrão 8,91, segundo o mesmo teste. Os valores de CEA não acompanharam persistências ou recidivas em cinco casos. Dez $(47,6 \%)$ curaram-se à operação, embora dois $(9,5 \%)$ tenham apresentado recidivas bioquímicas. Persistências neoplásicas foram caracterizadas em 11 pacientes $(52,4 \%)$, onde, em sete, os níveis séricos de CT permaneceram maiores que 30 vezes o máximo valor de referência. Entre o momento do tratamento inicial e 118 meses após, oito pacientes $(61,5 \%$ dos pacientes esporádicos com doença ativa) evoluíram com evidências clínicas ou imagenológicas de doença cervical e/ou a distância. Três foram re-operados, sem normalização de calcitonemias. Três pacientes faleceram, com doença local e distante ou somente a distância. O tempo de seguimento variou de quatro a 189 meses (média de 66,14 meses, desvio padrão 56,99 - teste t-Student).

Entre os 16 casos familiares, 15 foram classificados como portadores de NEM2A e, um, de NEM2B. Média etária foi calculada em 21,75 anos (de nove a 37 anos completos, desvio padrão 8,95 - teste t-Student), sendo estatisticamente significativa sua diferença em relação à média de idade daqueles classificados como casos esporádicos ( $\mathrm{p}<0,0001$, segundo o mesmo teste). Com a exclusão dos casos rastreados, permanecem três pacientes com idades de 10, 33 e 37 anos (média de 
26,66 anos). Dez (62,5\% destes 16) eram mulheres. Em 15 casos o CMT foi diagnosticado em momento anterior ao tratamento operatório, sendo 13 através de rastreamento. Onze $(68,8 \%)$ já contavam com nódulos tireóideos e/ou adenomegalias palpáveis ao exame físico. Nove pacientes (56,2\%) apresentaram metástases linfonodais cervicais, sendo quatro com extensão para estruturas adjacentes. Foram estadiados como I (seis casos), II (um caso), III (um caso) e IV A (oito casos).

Calcitonemias iniciais estiveram entre títulos normais e até 155 vezes o limite superior de referência (média de 28,07, desvio padrão 42,64 - teste t-Student), enquanto dosagens séricas de CEA variaram de valores normais a 59 vezes o máximo valor de referência (média de 12,54, desvio padrão 21,47 - segundo o mesmo teste), não se elevando em quatro casos, apesar de doença ativa. Não se obteve diferença estatística quanto aos títulos iniciais de CT e CEA entre os dois grupos $(\mathrm{p}=0,1446$ e $\mathrm{p}=0,6228$, respectivamente, segundo testes t-Student com variâncias iguais e desiguais, também respectivamente).

Cura foi alcançada por 10 pacientes $(62,5 \%)$, comumente logo após a operação, e recidiva foi observada em três casos $(18,8 \%), 12,28$ e 71 meses após os diagnósticos de cura bioquímica. Persistência foi observada em seis pacientes (37,5\%). Nestes nove casos, os níveis de CT basal foram bastante distintos. Evidências clínicas ou imagenológicas de doença cervical foram obtidas para quatro pacientes $(44,4 \%$ dos pacientes familiares com doença ativa), sendo dois portadores de metástases a distância também. Entre estes, um faleceu e, ao final do seguimento, sete encontravam-se vivos e sem doença $(43,8 \%)$ e oito vivos e com doença $(50 \%)$, sendo somente bioquímica em cinco. O tempo médio de seguimento para este grupo variou de 4 a 169 meses (64,94 meses em média, desvio padrão 44,29 - teste t- 
Student). Os dados citados, entre outros, estão representados na Tabela 12, contrapondo as formas esporádica e familiar do CMT.

Tabela 12 - Dados clinicopatológicos analisados para os pacientes segundo as duas formas de doença: esporádica e familiar

\begin{tabular}{|c|c|c|c|c|}
\hline \multirow{3}{*}{ VARIÁVEL } & \multicolumn{4}{|c|}{ FORMA DE DOENÇA } \\
\hline & \multicolumn{2}{|c|}{ ESPORÁDICA } & \multicolumn{2}{|c|}{ FAMILIAR } \\
\hline & N/Total & $\%$ & N/Total & $\%$ \\
\hline Idade (média em anos) & 42 & - & 21,75 & - \\
\hline Sexo (feminino:masculino) & $2: 1$ & - & $1,66: 1$ & - \\
\hline Diagnóstico pré-operatório & $12 / 21$ & 57,1 & $15 / 16$ & 93,6 \\
\hline Exame físico positivo ${ }^{(1)}$ & $19 / 21$ & 90,5 & $11 / 16$ & 68,8 \\
\hline Sintomas sistêmicos ${ }^{(1)}$ & $5 / 21$ & 23,8 & $2 / 16$ & 12,5 \\
\hline Valor relativo inicial de CT (média) & 249,08 & - & 28,07 & - \\
\hline Valor relativo inicial de CEA (média) & 8,62 & - & 12,54 & - \\
\hline Multicentricidade & $6 / 21$ & 28,6 & $15 / 16$ & 93,8 \\
\hline Presença de HCC & $3 / 21$ & 14,3 & $12 / 16$ & 75,0 \\
\hline Presença de amilóide & $14 / 21$ & 66,7 & $7 / 16$ & 43,8 \\
\hline Extensão capsular & $6 / 21$ & 28,6 & $7 / 16$ & 43,8 \\
\hline Extensão adjacente & $2 / 21$ & 40,5 & $3 / 16$ & 18,8 \\
\hline Invasão vascular & $4 / 21$ & 19 & $5 / 16$ & 31,2 \\
\hline Metástases linfonodais & $12 / 21$ & 57,1 & $9 / 16$ & 56,2 \\
\hline Extensão capsular linfonodal & $6 / 12$ & 50,0 & $4 / 9$ & 44,4 \\
\hline Metástases a distância ${ }^{(1)}$ & $1 / 21$ & 4,8 & $0 / 16$ & - \\
\hline Estádio I ${ }^{(2)}$ & $3 / 21$ & 14,3 & $6 / 16$ & 37,5 \\
\hline Estádio II ${ }^{(2)}$ & $3 / 21$ & 14,3 & $1 / 16$ & 6,2 \\
\hline Estádio III ${ }^{(2)}$ & $3 / 21$ & 14,3 & $1 / 16$ & 6,2 \\
\hline Estádio IV A ${ }^{(2)}$ & $9 / 21$ & 42,9 & $8 / 16$ & 50,0 \\
\hline Estádio IV B (2) & $1 / 21$ & 4,8 & $0 / 16$ & - \\
\hline Cura inicial & $10 / 21$ & 47,6 & $10 / 16$ & 62,5 \\
\hline Recidiva & $2 / 10$ & 20,0 & $3 / 10$ & 30,0 \\
\hline Persistência & $11 / 21$ & 52,4 & $6 / 16$ & 37,5 \\
\hline $\begin{array}{l}\text { Evidências clínicas ou imagenológicas de } \\
\text { neoplasia }\end{array}$ & $8 / 13$ & 61,5 & $4 / 9$ & 44,4 \\
\hline VSD & $8 / 21$ & 38,1 & $7 / 16$ & 43,8 \\
\hline VCD & $10 / 21$ & 47,6 & $8 / 16$ & 50,0 \\
\hline MCD & $3 / 21$ & 14,3 & $1 / 16$ & 6,3 \\
\hline
\end{tabular}

NOTAS: $\mathrm{N} /$ Total = número de pacientes afetados sobre o número de pacientes do subgrupo

- $\quad$ Não se aplica.

(1) À admissão.

(2) Estádio TNM patológico.

VSD Vivo sem doença ao final do seguimento.

VCM Vivo com doença ao final do seguimento.

MCD Morto pela doença.

Dados desconhecidos foram tidos como negativos ou desconsiderados nesta análise, diferentemente de em sessão "Caracterização dos Casos", quando citados. 


\subsubsection{RECIDIVAS NEOPLÁSICAS}

Cinco pacientes $(13,5 \%$ entre os 37 totais ou $25 \%$ entre os 20 tidos como curados após a operação inicial) relativos aos casos 4, 7, 14, 34 e 35 apresentaram recidivas de suas neoplasias, diagnosticadas por re-elevação de níveis séricos de CT, em seis, 12, 14, 28 e 71 meses de sua normalização (média de 26,2 meses, mediana de 14 meses). Um paciente manteve títulos de CT entre mais que três e até 10 vezes o valor máximo de referência, dois pacientes os mantiveram entre mais que 10 e até 30 vezes os valores máximos de referência e dois pacientes os mantiveram em mais de 100 vezes. No pós-operatório imediato, suas calcitonemias haviam sido 1,66;28,6 e 68,4 vezes maiores que os máximos limites de referência. Dois pacientes não contaram com tais registros. Um paciente apresentou evidências clínicas de recidiva em região cervical, passados 51 meses da normalização pós-operatória de CT sérica e, até o final da coleta de dados deste trabalho, não havia sido submetido a procedimento terapêutico complementar. Os demais mantiveram somente doença bioquímica. Os níveis séricos de CEA permaneceram dentro dos limites da normalidade em três destes pacientes. Todos os cinco estavam vivos ao final da coleta de dados para este trabalho.

Tais pacientes contavam com idades que variaram de 19 a 42 anos (média de 31,8 anos) ao diagnóstico de CMT. Quatro eram mulheres e, um, homem. Seus diagnósticos haviam sido feitos antes da operação, sendo, em dois, por rastreamento. Um paciente já apresentava adenomegalia metastática cervical ao exame físico e, os quatro restantes, nódulos tireóideos palpáveis. Dois casos eram esporádicos e, os 
outros três, vinculados à NEM2A. Todos foram submetidos à tireoidectomia total no primeiro tempo operatório, dois aos esvaziamentos central e lateral bilateralmente, um ao esvaziamento somente lateral bilateral, um aos esvaziamentos central e lateral unilateral e um ao esvaziamento do compartimento central. Os maiores diâmetros neoplásicos variaram de seis a $30 \mathrm{~mm}$. Em dois pacientes também foram observados focos de tireoidite em concomitância com o tumor. Três pacientes portavam metástases linfonodais cervicais e, nenhum, metástases a distância, sendo três estadiados inicialmente como IV A e os demais como Estádios I e II. (Tabela 13)

\subsubsection{PERSISTÊNCIAS NEOPLÁSICAS}

Persistências neoplásicas foram observadas em 17 pacientes do grupo (45,9\%). Um deles não contava com registros de dosagens séricas evolutivas de CT e CEA, mas apresentava metástase a distância (arco costal), ressecada ao diagnóstico. Apresentou teste sob estímulo elevado para CT durante sua evolução, embora o prontuário médico não contivesse os valores absolutos relativos ao exame. Faleceu, após 14 meses, por metástase em mediastino. Os demais pacientes caracterizados por persistências neoplásicas apresentavam valores de CT basal entre 4,11 e 2240 vezes os valores máximos de referência, ao diagnóstico ou pós-operatório imediato, média calculada em 245,58 e desvio padrão de 588,32, segundo teste t-Student, contra média de 13,74 (desvio padrão 20,41, segundo o mesmo teste) entre aqueles que se curaram em primeiro momento, diferença estatisticamente significativa $(p=0,0020$ - 
teste t-Student com variâncias iguais). No mesmo momento, os valores de CEA variaram de 1,08 a 59 vezes os máximos valores de referência, entre aqueles pacientes submetidos a tal dosagem (média de 15,1, desvio padrão 20,82 - teste tStudent). Não se observou diferença estatística para esta variável entre os dois grupos ( $\mathrm{p}=0,2483$ - teste t-Student com variâncias desiguais). Durante suas evoluções, os valores basais de CT estiveram entre mais que três até 10 vezes os limites máximos em três pacientes, entre mais que 10 até 30 vezes os valores máximos em dois pacientes, entre mais que 30 até 100 vezes em dois pacientes e em mais que 100 vezes em nove pacientes. Os valores séricos de CEA mantiveram-se elevados em oito pacientes, sendo que, sobre três, tais dados não haviam sido relatados. Foi comprovada presença de doença cervical em 10 destes indivíduos $(58,8 \%)$ e, em sete $(41,2 \%)$, doença metastática distante, com sobreposição de seis casos. Quatro (casos $12,15,18$ e 21) foram submetidos à re-exploração cervical, sem normalização de calcitonemia, mas mantendo-se vivos apesar da doença, após 124, 146, 84 e 128 meses de seguimento, respectivamente. O tempo para surgimento de evidências de doença local ou a distância variou de zero (concomitante) a 118 meses (média de 23,9 meses). Destes onze pacientes com evidências clínicas ou imagenológicas de neoplasia, quatro (casos 12, 16, 22 e 24) foram submetidos à terapia complementar (radioterapia ou quimioterapia), sem sucesso. Quatro $(23,5 \%)$ faleceram pela doença (casos 8, 16, 22 e 24) e 13 estavam vivos até o final dos seguimentos de quatro a 169 meses (67,71 meses em média para o grupo, desvio padrão 55,78 - teste t-Student).

Entre os que evoluíram com persistência neoplásica, média etária foi calculada em 35,47 anos, desvio padrão 15,37, segundo teste t-Student (idades entre 10 e 65 anos). Treze pacientes (76,5\% destes 17$)$ eram do sexo feminino, onze 
$(64,7 \%)$ portadores de CMT-E, cinco $(29,4 \%)$ de CMT NEM2A e um $(5,9 \%)$ de CMT NEM2B. O diagnóstico pré-operatório da neoplasia havia sido realizado em 12 pacientes $(70,6 \%)$, sendo três submetidos a rastreamentos e um a USG cervical de rotina. Oito pacientes $(47,1 \%)$ já apresentavam nódulos tireóideos e adenomegalias cervicais palpáveis ao diagnóstico, um (5,9\%), somente adenomegalia cervical e, oito (47,0\%), somente nódulos tireóideos ao exame físico. Quatro referiam sintomas sistêmicos. Dois não foram submetidos à tireoidectomia total (tumores primários inoperáveis), sendo que um deles também não o foi a nenhum tipo de linfadenectomia, por irressecabilidade. Ambos faleceram (casos 8 e 24). Dois pacientes foram submetidos a esvaziamentos das cadeias cervicais laterais bilateralmente, nove aos esvaziamentos central e lateral bilateral, quatro aos esvaziamentos central e lateral unilateral e um à linfadenectomia somente do compartimento central. As medidas dos maiores diâmetros neoplásicos variaram de 9 mm ao acometimento de toda a extensão da glândula, incluindo tecidos adjacentes (quatro pacientes). Em oito casos (47\%), os tumores atingiam as cápsulas da glândula e multicentricidade foi observada em 11 (64,7\%), sendo seis CMT-E, cinco NEM2A e um NEM2B. HCC foi observada em quatro casos (três NEM2A e um CMT-E), bem como associação de bócio em dois espécimes e presença de amilóide em $10(58,8 \%)$. Quinze pacientes $(88,2 \%)$ já apresentavam invasões vasculares e 16 (94,1\%) metástases para linfonodos cervicais, sendo nove $(52,9 \%)$ com extensões neoplásicas além dos limites linfonodais. Um paciente $(5,9 \%)$ já apresentava metástases a distância ao diagnóstico, sendo três estadiados como III, 12 como IV A e um como IV C. Um não pode ser estadiado por indisponibilidade de dados. A 
Tabela 13 expõe os dados clinicopatológicos citados, em separado para os pacientes que se curaram inicialmente, cujas neoplasias recidivaram ou persistiram.

Tabela 13 - Dados clinicopatológicos analisados para os pacientes segundo cura inicial, recidiva ou persistência do CMT

\begin{tabular}{|c|c|c|c|c|c|c|}
\hline \multirow{3}{*}{ VARIÁVEL } & \multicolumn{6}{|c|}{ EVOLUÇÃO INICIAL } \\
\hline & \multicolumn{2}{|c|}{$\begin{array}{l}\text { CURA } \\
\text { INICIAL }\end{array}$} & \multicolumn{2}{|c|}{ RECIDIVA } & \multicolumn{2}{|c|}{ PERSISTÊNCIA } \\
\hline & N/Total & $\%$ & $\mathrm{~N} /$ Total & $\%$ & N/Total & $\%$ \\
\hline Idade (média em anos) & 31,35 & - & 31,8 & - & 35,47 & - \\
\hline Sexo (feminino:masculino) & $1,22: 1$ & - & $4: 1$ & - & $3,25: 1$ & 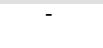 \\
\hline Diagnóstico pré-operatório & $15 / 20$ & 75,0 & $5 / 5$ & 100,0 & $12 / 17$ & 70,6 \\
\hline Exame físico positivo ${ }^{(1)}$ & $13 / 20$ & 65,0 & $5 / 5$ & 100,0 & $17 / 17$ & 100,0 \\
\hline Sintomas sistêmicos ${ }^{(1)}$ & $3 / 20$ & 15,0 & $1 / 5$ & 20,0 & $4 / 17$ & 23,5 \\
\hline Forma Esporádica & $10 / 20$ & 50,0 & $2 / 5$ & 40,0 & $11 / 17$ & 64,7 \\
\hline Forma Familiar & $10 / 20$ & 50,0 & $3 / 5$ & 60,0 & $6 / 17$ & 35,3 \\
\hline Valor relativo inicial de $\mathrm{CT}$ (média) & 13,74 & - & 32,89 & - & 245,58 & - \\
\hline Valor relativo inicial de CEA (média) & 6,01 & - & 1,82 & - & 15,1 & - \\
\hline Multicentricidade & $10 / 20$ & 50,0 & $3 / 5$ & 60,0 & $11 / 17$ & 64,7 \\
\hline Presença de HCC & $11 / 20$ & 55,0 & $5 / 5$ & 100,0 & $4 / 17$ & 23,5 \\
\hline Presença de amilóide & $11 / 20$ & 55,0 & $3 / 5$ & 60,0 & $10 / 17$ & 58,8 \\
\hline Extensão capsular & $5 / 20$ & 25,0 & $3 / 5$ & 60,0 & $8 / 17$ & 47,0 \\
\hline Extensão adjacente & $1 / 20$ & 5,0 & $1 / 5$ & 20,0 & $4 / 17$ & 23,5 \\
\hline Invasão vascular & $3 / 20$ & 15,0 & $2 / 5$ & 40,0 & $15 / 17$ & 88,2 \\
\hline Metástases linfonodais & $5 / 20$ & 25,0 & $3 / 5$ & 60,0 & $16 / 17$ & 94,1 \\
\hline Extensão capsular linfonodal & $1 / 5$ & 20,0 & $1 / 3$ & 33,3 & $9 / 16$ & 56,2 \\
\hline Metástases a distância ${ }^{(1)}$ & $0 / 20$ & - & $0 / 5$ & - & $1 / 17$ & 5,9 \\
\hline Estádio I ${ }^{(2)}$ & $9 / 20$ & 45,0 & $1 / 5$ & 20,0 & $0 / 17$ & - \\
\hline Estádio II ${ }^{(2)}$ & $4 / 20$ & 20,0 & $1 / 5$ & 20,0 & $0 / 17$ & - \\
\hline Estádio III $^{(2)}$ & $1 / 20$ & 5,0 & $0 / 5$ & - & $3 / 17$ & 17,6 \\
\hline Estádio IV A ${ }^{(2)}$ & $5 / 20$ & 25,0 & $3 / 5$ & 60,0 & $12 / 17$ & 70,6 \\
\hline Estádio IV B ${ }^{(2)}$ & $0 / 20$ & - & $0 / 5$ & - & $1 / 17$ & 5,9 \\
\hline $\begin{array}{l}\text { Evidências clínicas ou imagenológicas de } \\
\text { neoplasia }\end{array}$ & $0 / 20$ & - & $1 / 5$ & 20,0 & $11 / 17$ & 64,7 \\
\hline VSD & $15 / 20$ & 75,0 & $0 / 5$ & - & $0 / 17$ & - \\
\hline VCD & $5 / 20$ & 25,0 & $5 / 5$ & 100,0 & $13 / 17$ & 76,5 \\
\hline MCD & $0 / 20$ & - & $0 / 5$ & - & $4 / 17$ & 23,5 \\
\hline
\end{tabular}

NOTAS: $\mathrm{N} /$ Total $=$ número de pacientes afetados sobre o número de pacientes do subgrupo.

- $\quad$ Não se aplica.

(1) À admissão.

(2) Estádio TNM patológico.

VSD Vivo sem doença ao final do seguimento.

VCM Vivo com doença ao final do seguimento.

MCD Morto pela doença.

Dados desconhecidos foram tidos como negativos ou desconsiderados nesta análise, diferentemente de em sessão "Caracterização dos Casos", quando citados. 


\subsubsection{VIVOS E SEM DOENÇA}

Quinze pacientes (40,5\%) encontravam-se vivos e sem doença ao final do seguimento. Estes foram acompanhados por períodos de quatro a 189 meses (média de 54, 4 meses e desvio padrão 51,66 meses - teste F, ANOVA) e tinham entre nove e 56 anos de idade ao diagnóstico, média de 31,2 anos, menor que dos vivos com doença e mortos pela doença, diferença, porém, sem significância estatística $(\mathrm{p}=$ 0,5844 - teste F, ANOVA). Oito eram homens, contra sete mulheres e o diagnóstico pré-operatório havia sido feito em $10(66,7 \%)$ destes pacientes, sendo sete através de rastreamento e dois por achado de USG. Apenas uma paciente contava com nódulo tireóideo e adenomegalias cervicais palpáveis ao exame físico, enquanto que sete contavam apenas com nódulos tireóideos palpáveis à época do diagnóstico. Duas pacientes $(13,3 \%)$ referiam emagrecimento ao diagnóstico da neoplasia. Treze foram submetidos à tireoidectomia total em primeiro tempo operatório, acompanhada dos esvaziamentos central e lateral bilateral em oito casos, central e unilateral em um caso e somente central em um caso. Cinco pacientes não foram submetidos a nenhum tipo de linfadenectomia, três incluídos nos programas de rastreamento e sem nódulos tireóideos palpáveis (todos T1N0M0) e duas mulheres cujos diagnósticos haviam sido realizados no pós-operatório, já sendo portadoras de nódulos tireóideos palpáveis. Uma delas mantinha retornos periódicos ao ambulatório há 189 meses, até o final da coleta de dados, e a outra foi acompanhada por 67 meses, mas não retornava ao ambulatório havia 15 anos. Multicentricidade foi observada em sete pacientes, todos portadores da forma familiar da neoplasia, assim como associação 
de HCC (seis pacientes). Extensão neoplásica para a cápsula tireóidea foi observada em dois pacientes $(13,3 \%)$, mas sem acometimento de estruturas adjacentes. Invasão vascular foi observada em um espécime neoplásico $(6,7 \%)$ e apenas dois pacientes eram portadores de metástases linfonodais cervicais. Nenhum paciente contava com metástases a distância, sendo oito classificados como Estádio I, três como Estádio II, um como Estádio III e dois como Estádio IV A. Um paciente não foi estadiado. Associações de bócio, tireoidite e carcinoma papilífero foram observadas em três, três e um caso, respectivamente. Oito pacientes (53,3\%) eram portadores de CMT-E e, sete, da forma familiar da doença (NEM2A). Calcitonemias basais iniciais variaram de resultados normais a até mais de 30 vezes os máximos valores de referência. A média destas dosagens para o grupo de vivos e sem doença $(7,35$, desvio padrão 10,37 - teste F, ANOVA) foi menor que para os vivos com doença e que faleceram pelo CMT, com identificação de diferença estatisticamente significativa entre as médias dos dois primeiros grupos $(\mathrm{p}=0,0028$, segundo o mesmo teste). Para o CEA, neste mesmo momento, dosagens séricas também variaram de resultados normais a até 23,5 vezes os máximos valores de referência, média 8,11 e desvio padrão 9,69 (teste F, ANOVA). Não foram todos os pacientes que contaram com tais exames. Seus valores médios foram menores entre aqueles vivos sem doença e vivos com doença, quando comparados com os mortos pela doença, embora as diferenças não fossem estatisticamente significativas $(p=0,5325$, segundo o mesmo teste estatístico). Na Tabela 14 os dados clinicopatológicos relativos às três condições clínicas finais são expostos. 
Tabela 14 - Dados clinicopatológicos segundo condições clínicas finais

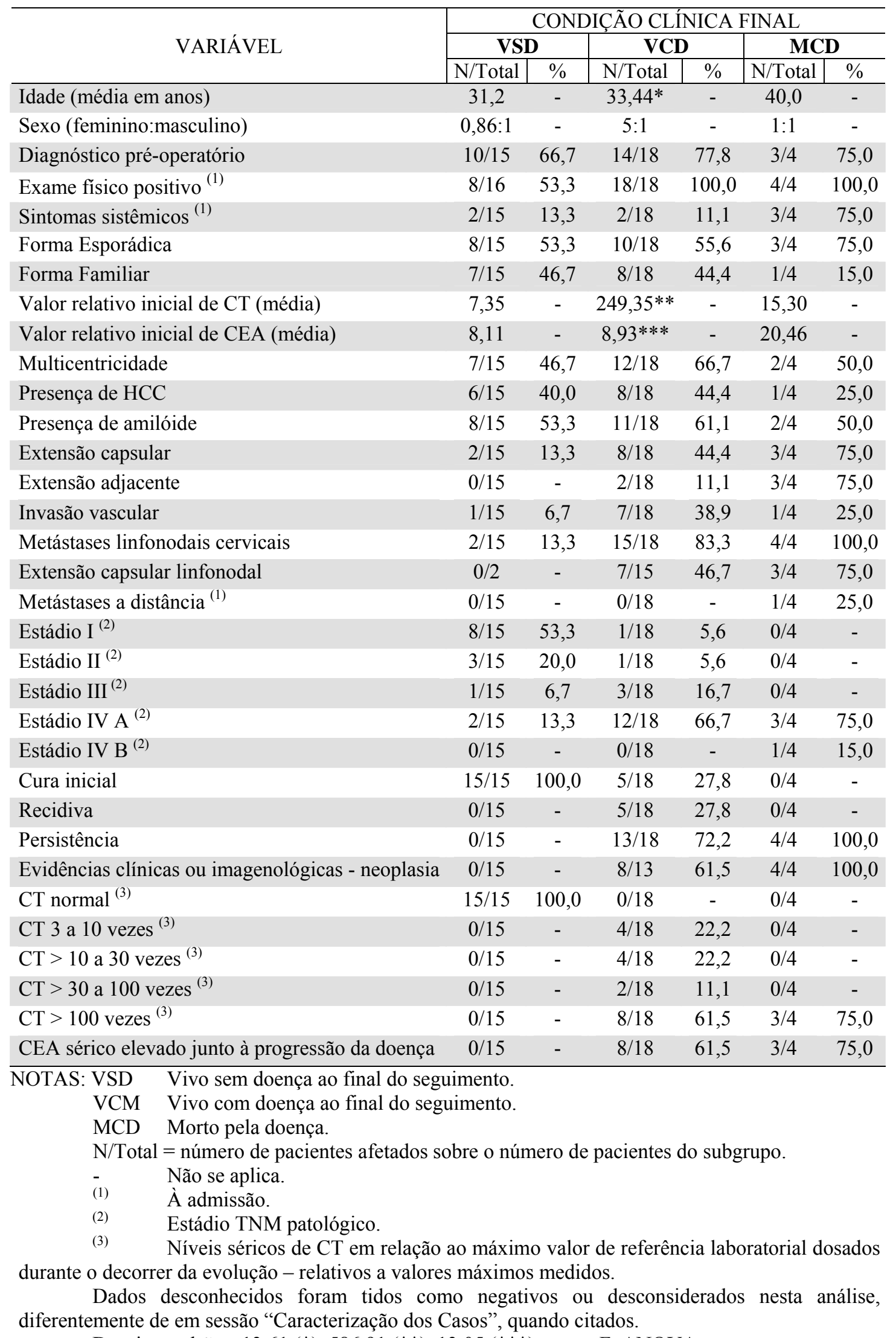

Desvios padrões: $13,61(*), 586,91(* *), 13,05(* * *)$ - teste F, ANOVA. 


\subsection{5 ÓBITOS}

Quatro pacientes (10,8\%) (casos 8, 16, 22 e 24) faleceram, entre 14 e 88 meses de seguimento (média de 34,25 meses, desvio padrão 35,89 - teste $\mathrm{F}$, ANOVA). Todos morreram pelo CMT, um com doença local irressecável, um com doença metastática a distância e dois com doenças cervical e a distância. Os diagnósticos destes pacientes haviam sido feitos quando os mesmos contavam com 25, 26, 44 e 65 anos (média de 40 anos, desvio padrão 18,81 - teste F, ANOVA), sendo dois homens e duas mulheres. Uma paciente participou do programa de rastreamento, mas já portava doença avançada (T4aN1bM0). Todos contavam com doença cervical palpável ao exame físico e três apresentavam sintomas sistêmicos, diarréia ou emagrecimento. Sintomas relativos ao acometimento de estruturas laríngeas, como disfonia e dispnéia, também foram relatados (casos 8 e 24). Valores médios de CT e CEA séricos iniciais foram calculados em 15,30 e 20,46 vezes os maiores limites laboratoriais, respectivamente (desvios padrões 15,30 e 20,46, respectivamente - teste F, ANOVA).

Dois pacientes, apesar de submetidos ao tratamento cirúrgico cervical, foram considerados inoperáveis. Os maiores diâmetros das neoplasias primárias variaram de $15 \mathrm{~mm}$ ao acometimento de toda a glândula tireóide. Três tumores invadiam estruturas adjacentes à glândula e os quatro pacientes já apresentavam metástases linfonodais cervicais à operação, sendo três com extensões neoplásicas extralinfonodais. Um paciente apresentava evidências clínicas de metástases a distância (único caso do grupo total) ao diagnóstico de CMT (caso 22), sendo 
classificado como Estádio IV C. Os outros três foram classificados como Estádio IV A. Todos persistiram com indícios de neoplasia, sendo que três mantiveram dosagens de CT acima de 100 vezes os valores máximos estipulados como referência. Um paciente contou somente com dosagem de CT sob estímulo e o valor absoluto do resultado do exame não estava disponível em seu prontuário médico, embora estivesse caracterizado como positivo (caso 22). Não contou também com dosagens séricas de CEA em seu seguimento. Outro paciente (caso16) apresentou títulos séricos de CEA dentro dos limites da normalidade no decorrer de sua evolução.

Evidências clínicas de doença persistente foram concomitantes ao tratamento cirúrgico em três pacientes e diagnosticadas, após oito meses, em indivíduo (caso 16) que evoluiu com metástases a distância em diversos sítios. A três pacientes foi oferecida terapia complementar, quimioterapia ou radioterapia, sem sucesso.

\subsubsection{RASTREAMENTO}

Treze pacientes $(35,1 \%)$ foram diagnosticados através de rastreamentos, oito mulheres (61,5\% entre os 13 do grupo) e cinco homens, entre nove e 36 anos de idade e média de 20,61 anos (desvio padrão 7,57 - teste t-Student), contra média de 40,08 anos (desvio padrão 13,23, segundo o mesmo teste) entre os não-rastreados, diferença significativamente estatística $(\mathrm{p}<0,0001$ - teste t-Student com variâncias desiguais). Sete $(53,8 \%)$ já apresentavam nódulos tireóideos palpáveis ao exame físico e um (7,7\%), além de nódulo tireóideo, adenomegalia metastática cervical. 
Dois já referiam sintomas sistêmicos. Doze foram submetidos à tireoidectomia total e uma paciente sofreu somente ressecção parcial por irressecabilidade (caso 8). Seis pacientes foram submetidos aos esvaziamentos central e lateral bilateral, dois ao esvaziamento somente do compartimento central cervical e, um, à linfadenectomia lateral bilateral. Três pacientes com tumores primários de $1 \mathrm{~mm}, 5 \mathrm{~mm}$ e $6 \mathrm{~mm}$ e com dosagens séricas basais de CT dentro dos limites de referência (mas dosagens aumentadas de CT sob estímulo) não foram submetidos à linfadenectomia cervical. Os três estavam curados ao final deste trabalho e contavam com mais de 40 meses de seguimento, cada um.

Cinco pacientes $(38,5 \%)$ portavam tumores com extensões para a cápsula tireóidea, sendo dois já com acometimento de estruturas adjacentes à glândula. Apenas um paciente, entre estes cinco, curou-se. Em três casos relatou-se presença de invasão vascular e seis $(46,2 \%)$ já apresentavam metástases linfonodais cervicais. Apenas um paciente curou-se entre esses seis. Seis pacientes foram classificados como Estádio I, um como Estádio II, um como Estádio III e cinco como Estádio IV A. Dosagens séricas basais de $\mathrm{CT}$, ao diagnóstico do $\mathrm{CMT}$, variaram de títulos normais a 154 vezes o máximo valor de referência, média de 31,07, desvio padrão 45,94 (teste t-Student), sem diferença estatística quanto a tais medidas para pacientes não-rastreados ( $\mathrm{p}=$ 0,2067 - teste t-Student com variâncias iguais).

Nove pacientes $(69,2 \%)$ alcançaram cura inicial, sendo que dois $(15,4 \%)$ evoluíram com recidivas, 12 e 71 meses após o tratamento operatório inicial, e quatro apresentaram persistências neoplásicas. Dos seis pacientes que não se curaram, as dosagens de CT durante seus seguimentos estiveram maiores que 10 até 30 vezes os valores máximos de referência em três pacientes e maiores que 100 vezes nos outros 
três. Doenças cervical e metastática foram diagnosticadas em dois indivíduos, após 72 e 80 meses do tratamento operatório. Um deles foi submetido a quimioterapia para metástases hepáticas e mediastinais, mas sem sucesso. Ao final dos seguimentos, sete $(53,8 \%)$ estavam vivos e sem doença, cinco $(38,5 \%)$ vivos com doença local e um (7,7\%) morto. Dos vivos e com doença ao final do seguimento, três abandonaram o acompanhamento ambulatorial, estando dois sabidamente vivos (informações de familiares). A Tabela 15 expõe os dados clinicopatológicos observados para os pacientes cujas neoplasias foram diagnosticadas através de rastreamento e por achados de USG cervical de rotina.

\subsubsection{ACHADOS DE EXAMES}

Três pacientes do sexo feminino com idades de 47, 54 e 56 anos tiveram seus tumores diagnosticados através de USG cervical de rotina. Apenas uma apresentava nódulo tireóideo passível de palpação $(15 \mathrm{~mm})$ e já com invasão vascular e acometimento linfonodal, inclusive com extravasamento neoplásico. As três foram submetidas à tireoidectomia total e linfadenectomias dos compartimentos central e lateral bilateralmente, sendo duas estadiadas como T1N0M0 e a terceira como T1N1bM0. Apenas esta última não se curou, mantendo-se viva, com calcitonemia elevada (entre mais que 30 e 100 vezes os níveis máximos de referência), dosagens séricas de CEA dentro dos limites de referência e sem evidências clínicas ou 
imagenológicas de neoplasia, após 28 meses de seguimento. As duas outras pacientes são seguidas há oito e 22 meses. (Tabela 15)

Tabela 15 - Dados clinicopatológicos segundo forma de diagnóstico: através de rastreamento ou achado de USG cervical de rotina

\begin{tabular}{|c|c|c|c|c|}
\hline \multirow{3}{*}{ VARIÁVEL } & \multicolumn{4}{|c|}{ DIAGNÓSTICO } \\
\hline & \multicolumn{2}{|c|}{ RASTREAMENTO } & \multicolumn{2}{|c|}{ ACHADO USG } \\
\hline & $\mathrm{N} /$ Total & $\%$ & N/Total & $\%$ \\
\hline Idade (média em anos) & 20,61 & - & 52,33 & - \\
\hline Sexo (feminino:masculino) & $1,6: 1$ & - & $3: 0$ & - \\
\hline Exame físico positivo ${ }^{(1)}$ & $8 / 13$ & 61,5 & $1 / 3$ & 33,3 \\
\hline Sintomas sistêmicos ${ }^{(1)}$ & $2 / 13$ & 15,4 & $0 / 3$ & - \\
\hline Valor relativo inicial de CT (média) & 31,07 & - & 133,65 & - \\
\hline Valor relativo inicial de CEA (média) & 13,98 & - & 1,0 & - \\
\hline Multicentricidade & $12 / 13$ & 92,3 & $1 / 3$ & 33,3 \\
\hline Presença de HCC & $11 / 13$ & 84,6 & $0 / 3$ & - \\
\hline Presença de amilóide & $6 / 13$ & 46,2 & $2 / 3$ & 66,7 \\
\hline Extensão capsular & $5 / 13$ & 38,5 & $0 / 3$ & - \\
\hline Extensão adjacente & $2 / 13$ & 15,4 & $0 / 3$ & - \\
\hline Invasão vascular & $3 / 13$ & 23,1 & $1 / 3$ & 33,3 \\
\hline Metástases linfonodais & $6 / 13$ & 46,2 & $1 / 3$ & 33,3 \\
\hline Extensão capsular linfonodal & $2 / 6$ & 33,3 & $1 / 1$ & 100,0 \\
\hline Metástases a distância ${ }^{(1)}$ & $0 / 13$ & - & $0 / 3$ & - \\
\hline Estádio I ${ }^{(2)}$ & $6 / 13$ & 46,1 & $2 / 3$ & 66,7 \\
\hline Estádio II ${ }^{(2)}$ & $1 / 13$ & 7,7 & $0 / 3$ & - \\
\hline Estádio III ${ }^{(2)}$ & $1 / 13$ & 7,7 & $0 / 3$ & - \\
\hline Estádio IV A ${ }^{(2)}$ & $5 / 13$ & 38,5 & $1 / 3$ & 33,3 \\
\hline Estádio IV B ${ }^{(2)}$ & $0 / 13$ & - & $0 / 3$ & - \\
\hline Cura inicial & $9 / 13$ & 69,2 & $2 / 3$ & 66,7 \\
\hline Recidiva & $2 / 9$ & 22,2 & $0 / 3$ & - \\
\hline Persistência & $4 / 13$ & 30,8 & $1 / 3$ & 33,3 \\
\hline Evidências clínicas ou imagenológicas de neoplasia & $2 / 6$ & 33,3 & $0 / 1$ & - \\
\hline VSD & $7 / 13$ & 53,8 & $2 / 3$ & 66,7 \\
\hline $\mathrm{VCD}$ & $5 / 13$ & 38,5 & $1 / 3$ & 33,3 \\
\hline MCD & $1 / 13$ & 7,7 & - & - \\
\hline
\end{tabular}

NOTAS: $\mathrm{N} /$ Total $=$ número de pacientes afetados sobre o número de pacientes do subgrupo em questão.

\footnotetext{
- Não se aplica.

(1) À admissão.

(2) Estádio TNM patológico.

VSD Vivo sem doença ao final do seguimento.

VCM Vivo com doença ao final do seguimento.

MCD Morto pela doença.
}

Dados desconhecidos foram tidos como negativos ou desconsiderados nesta análise, diferentemente de em sessão "Caracterização dos Casos", quando citados. 


\subsubsection{METÁSTASES A DISTÂNCIA}

Sete $(18,9 \%)$ pacientes evoluíram com metástases a distância, evidentes clínica ou imagenologicamente, entre zero (concomitante) e 80 meses dos tratamentos operatórios iniciais (média de 25,57 meses). Três (42,9\% dentre estes sete) faleceram pela doença e uma paciente (rastreamento) não retornava às consultas há mais de dois anos, interrompendo o seguimento em vigência de presença de massa abdominal metastática. Suas idades variaram de 22 a 65 anos ao diagnóstico $(36,28$ anos em média, desvio padrão 16,61 - teste t-Student), sendo cinco mulheres e dois homens. Todos já apresentavam nódulos tireóideos palpáveis ao diagnóstico e, quatro, adenomegalias cervicais metastáticas também, apesar de dois pacientes deste grupo tiveram seus diagnósticos realizados a partir de rastreamento familiar. Dois (28,6\%) contavam com sintomas sistêmicos. Cinco foram classificados como esporádicos e os outros dois como NEM2A.

Um não foi submetido à exérese completa do tumor primário por irressecabilidade (caso 24), mas todos foram submetidos a algum tipo de linfadenectomia. Os maiores diâmetros das neoplasias primárias variaram de $15 \mathrm{~mm}$ até o acometimento de toda a extensão glandular, sendo que três pacientes apresentavam envolvimento neoplásico da cápsula da tireóide, entre os quais dois já contavam com envolvimento de estruturas adjacentes à glândula. Quatro tumores eram multicêntricos (três esporádicos e um NEM2A) e associação de HCC foi observada somente em um caso (NEM2A). Em dois tumores foi observada invasão vascular e, presença de amilóide, em cinco tumores primários. Todos contavam com 
metástases linfonodais cervicais, sendo que em três casos observou-se extensão neoplásica extralinfonodal. Os pacientes foram estadiados como III (dois), IV A (quatro) e IV C (um). Dosagens iniciais e basais de CT variaram de 4,1 a 378,6 vezes os valores máximos de referência (média de 108,08, desvio padrão 143,17 - teste tStudent). Seis pacientes evoluíram com dosagens basais de CT maiores que 100 vezes os valores máximos estipulados, sendo tais dados indisponíveis para um paciente. No pós-operatório imediato, os valores séricos de CEA variaram de níveis normais a mais de 40 vezes de aumento em relação aos valores máximos de referência (média de 12,57, desvio padrão 14,99 - teste t-Student). Em períodos pósoperatórios, três pacientes não evoluíram com elevação dos níveis de CEA, apesar de evidente progressão da doença.

Quatro pacientes foram submetidos a terapias complementares, destes, um mantinha-se vivo, apesar de metástases hepáticas e em mediastino diagnosticadas após 80 meses do tratamento inicial. Recebeu complementação quimioterápica.

As metástases a distância foram caracterizadas em mediastino, pulmões, fígado, arcos costais, ossos do ombro, fêmur, coluna lombar e cavidade peritonial.

\subsection{EXPRESSÃO DE MMP-2}

A Tabela 16 expressa a distribuição dos pacientes em relação à proporção de área neoplásica imunomarcada para MMP-2 e intensidade de coloração, tanto para o tumor primário, como para as metástases linfonodais, quando presentes. Expõe 
também o índice geral de imunocoloração para os tumores primários e as metástases linfonodais, índice este que associa a proporção de área neoplásica imunocorada com a intensidade de sua coloração. Os índices foram denominados "1", “2” e "3", como descrito na seção "Métodos".

Tabela 16 - Distribuição dos pacientes segundo as variáveis relativas à imunocoloração para MMP-2: proporção de área marcada em tumor tireóideo primário, intensidade de marcação em tumor primário, proporção de área marcada em metástase linfonodal, intensidade de marcação em metástase linfonodal, índice geral para tumor primário e índice geral para metástase linfonodal, segundo sistema de índices proposto na seção "Métodos"

\begin{tabular}{|c|c|c|c|c|c|c|c|c|}
\hline \multirow{3}{*}{$\begin{array}{c}\text { VARIÁVEL } \\
\text { MMP-2 }\end{array}$} & \multicolumn{6}{|c|}{ ÍNDICES } & \multirow{2}{*}{\multicolumn{2}{|c|}{ TOTAL }} \\
\hline & & 1 & & 2 & & 3 & & \\
\hline & $\mathrm{N}$ & $\%$ & $\mathrm{~N}$ & $\%$ & $\mathrm{~N}$ & $\%$ & $\mathrm{~N}$ & $\%$ \\
\hline
\end{tabular}

\section{- Intensidade de marcação em tumor primário}

$\begin{array}{lllllll}- & - & - & 36 & 100,0^{(1)} & 36 & 100,0\end{array}$

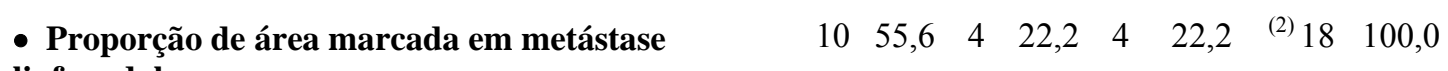
linfonodal

- Intensidade de marcação em metástase linfonodal - - - - $\quad-\quad 18 \quad 100,0{ }^{(2)} 18 \quad 100,0$

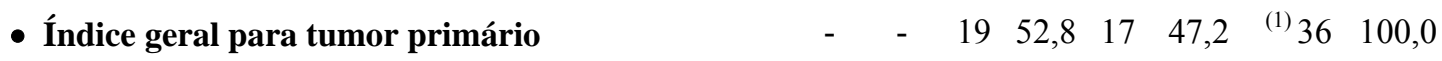

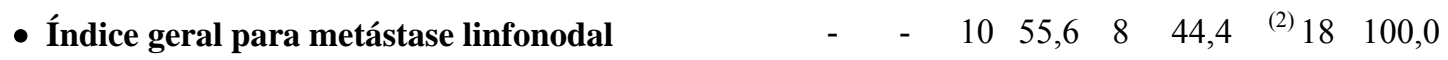
NOTAS: N refere-se ao número de pacientes.

(1) $\quad$ Ocorrência nula.
Para um paciente não se dispõe desta informação.

(2) Para três pacientes não se dispõe desta informação.

As imunocolorações para os espécimes primário e metastático de um paciente (caso 37) não foram bem sucedidas e os dados excluídos da Tabela 16, assim como não foi obtido material referente à metástase linfonodal de um caso (caso 8) e as imunorreações para a metástase linfonodal de outro paciente (caso 14) também não foram satisfatórias. 
Quatro pacientes tiveram suas metástases linfonodais classificadas como “Índice Geral 2", enquanto seus tumores primários o foram como "Índice Geral 3". O oposto aconteceu em um único caso. Nos demais casos, os resultados das análises entre espécimes primários e metastáticos de mesmo paciente foram equivalentes. A correlação não foi realizada para três casos, por indisponibilidade de dados.

\subsection{EXPRESSÃO DE MT1-MMP}

A Tabela 17 expressa a distribuição dos pacientes em relação à proporção de células neoplásicas imunomarcadas para MT1-MMP e intensidade de coloração, tanto para o tumor primário, como para as metástases linfonodais, quando presentes. Expressa também o índice geral de imunocoloração para os tumores primários e as metástases linfonodais, índice este que associa a proporção de células imunocoradas com a intensidade de sua coloração. Os índices foram denominados "1", "2" e "3", como descrito na seção "Métodos".

As imunocolorações para os tumores primários de dois pacientes (casos 9 e 18) não foram bem sucedidas e os dados excluídos da tabela a seguir, assim como não foi obtido material referente à metástase linfonodal de um caso (caso 8).

Entre 14 casos, os índices gerais obtidos para os tumores primários foram equivalentes aos das metástases em linfonodos ("Índice 3"). Para cinco tumores “Índice Geral 3", as respectivas metástases foram classificadas como “Índice Geral 2" e para um tumor "Índice Geral 3", sua lesão metastática correspondente foi 
classificada como "Índice Geral 1". A correlação não foi realizada para dois pacientes, por indisponibilidade de dados.

Tabela 17 - Distribuição dos pacientes segundo as variáveis relativas à imunocoloração para MT1-MMP: proporção de células marcadas em tumor tireóideo primário, intensidade de marcação em tumor primário, proporção de células marcadas em metástase linfonodal, intensidade de marcação em metástase linfonodal, índice geral para tumor primário e índice geral para metástase linfonodal, segundo sistema de índices proposto na seção "Métodos"

\begin{tabular}{|c|c|c|c|c|c|c|c|c|}
\hline \multirow{3}{*}{$\begin{array}{l}\text { VARIÁVEL } \\
\text { MT1-MMP }\end{array}$} & \multicolumn{6}{|c|}{ ÍNDICES } & \multirow{2}{*}{\multicolumn{2}{|c|}{ TOTAL }} \\
\hline & \multicolumn{2}{|c|}{1} & \multicolumn{2}{|c|}{2} & \multicolumn{2}{|c|}{3} & & \\
\hline & $\mathrm{N}$ & $\%$ & $\mathrm{~N}$ & $\%$ & $\mathrm{~N}$ & $\%$ & $\mathrm{~N}$ & $\%$ \\
\hline $\begin{array}{l}\text { - Proporção de células marcadas em } \\
\text { tumor primário }\end{array}$ & 3 & 8,6 & 7 & 20,0 & 25 & 71,4 & (1) 35 & 100,0 \\
\hline $\begin{array}{l}\text { - Intensidade de marcação em tumor } \\
\text { primário }\end{array}$ & - & - & 9 & 25,7 & 26 & 74,3 & (1) 35 & 100,0 \\
\hline $\begin{array}{l}\text { - Proporção de células marcadas em } \\
\text { metástase linfonodal }\end{array}$ & 5 & 25,0 & 1 & 5,0 & 14 & 70,0 & (2) 20 & 100,0 \\
\hline $\begin{array}{l}\text { - Intensidade de marcação em metástase } \\
\text { linfonodal }\end{array}$ & 2 & 10,0 & 9 & 45,0 & 9 & 45,0 & (2) 20 & 100,0 \\
\hline - Índice geral para tumor primário & - & - & 6 & 17,1 & 29 & 82,9 & (1) 35 & 100,0 \\
\hline - Índice geral para metástase linfonodal & 1 & 5,0 & 5 & 25,0 & 14 & 70,0 & (2) 20 & 100,0 \\
\hline
\end{tabular}
NOTA: N refere-se ao número de pacientes.
(1) Ocorrência nula.
(1) Para dois pacientes não se dispõe desta informação.
(2) Para um paciente não se dispõe desta informação.

\subsection{EXPRESSÃO DE TIMP-2}

A Tabela 18 expressa a distribuição dos pacientes em relação à proporção de células neoplásicas imunomarcadas para TIMP-2 e intensidade de coloração, tanto 
para o tumor primário, como para as metástases linfonodais, quando presentes. Expressa também o índice geral de imunocoloração para os tumores primários e as metástases em linfonodos, índice este que associa a proporção de células imunocoradas com a intensidade de sua coloração. Os índices foram denominados “1”, "2" e “3”, como descrito na seção "Métodos".

As imunocolorações para os tumores primários de três pacientes (casos 5, 9 e 23) não foram bem sucedidas e os dados excluídos da tabela a seguir, assim como não foi obtido material referente à metástase linfonodal de um caso (caso 8).

Tabela 18 - Distribuição dos pacientes segundo as variáveis relativas à imunocoloração para TIMP-2: proporção de células marcadas em tumor tireóideo primário, intensidade de marcação em tumor primário, proporção de células marcadas em metástase linfonodal, intensidade de marcação em metástase linfonodal, índice geral para tumor primário e índice geral para metástase linfonodal, segundo sistema de índices proposto na seção "Métodos"

\section{VARIÁVEL}

TIMP-2

- Proporção de células marcadas em tumor primário

- Intensidade de marcação em tumor primário

$\begin{array}{llllllll}3 & 8,8 & 11 & 32,4 & 20 & 58,8^{(1)} & 34 & 100,0\end{array}$

- Proporção de células marcadas em metástase linfonodal $\begin{array}{lllllll}- & - & 4 & 20,0 & 16 & 80,0^{(2)} 20 & 100,0\end{array}$

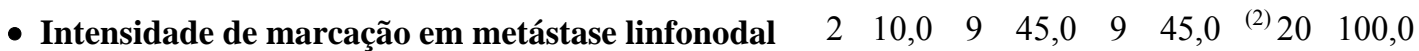

- Índice geral para tumor primário

\begin{tabular}{|c|c|c|c|c|c|c|c|}
\hline \multicolumn{6}{|c|}{ ÍNDICES } & \multirow{2}{*}{\multicolumn{2}{|c|}{ TOTAL }} \\
\hline & 1 & & & & & & \\
\hline $\mathrm{N}$ & $\%$ & $\mathrm{~N}$ & $\%$ & $\mathrm{~N}$ & $\%$ & $\mathrm{~N}$ & $\%$ \\
\hline
\end{tabular}

- Índice geral para metástase linfonodal NOTA: N refere-se ao número de pacientes.

- Ocorrência nula.

(1) Para três pacientes não se dispõe desta informação.

(2) Para um paciente não se dispõe desta informação. 
Os três pacientes cujos tumores primários foram classificados como "Índice Geral 2" e apresentavam metástases em linfonodos cervicais contaram com lesões metastáticas também “Índice Geral 2". No grupo “Índice Geral 3” para a neoplasia primária, apenas um caso contou com classificação diferente ("Índice 2") para sua lesão metastática linfonodal.

\subsection{ANÁLISE ESTATÍSTICA DAS VARIÁVEIS CLINICOPATOLÓGICAS}

As variáveis clinicopatológicas estudadas foram correlacionadas com as condições clínicas dos pacientes, a saber, vivo e sem evidências laboratoriais, clínicas e/ou imagenológicas de neoplasia (vivo e sem doença); vivo, mas com evidências de neoplasia, sendo estas bioquímicas (títulos séricos elevados de CT) somente ou associadas a indícios clínicos e/ou imagenológicos de CMT (vivo e com doença) e morto pela doença, ao final do período de seguimento. Todos os pacientes do grupo que faleceram o fizeram em decorrência do CMT. Os dados serão demonstrados através das tabelas a seguir (Tabelas 19 a 26). Os pacientes cujos dados para determinadas variáveis não foram obtidos foram excluídos das próximas tabelas, já tendo sido citados em tabelas anteriores em NOTAS.

As variáveis que apresentaram relações estatisticamente significativas com as condições clínicas dos pacientes ao término dos seguimentos, segundo análises demonstradas nas tabelas a seguir, foram: evidência de lesão tireóidea e/ou em 
cadeias linfonodais ao exame físico cervical inicial $(p=0,0017)$, presença de sintomas sistêmicos ao diagnóstico de CMT $(\mathrm{p}=0,0288)$, extensão neoplásica através da cápsula da tireóide $(\mathrm{p}=0,0375)$, extensão neoplásica para tecidos adjacentes à glândula $(\mathrm{p}=0,0024)$; presença de invasão vascular, sanguínea e/ou linfática $(\mathrm{p}=0,0142)$, metástases linfonodais cervicais $(\mathrm{p}<0,0001)$, estádio TNM ( $\mathrm{p}$ $=0,0005)$ e forma de progressão da doença entre aqueles que não se curaram, ou seja, somente doença bioquímica ou com evidências clínicas e/ou imagenológicas de doença cervical e/ou a distância $(p=0,0335)$. Todos os pacientes vivos e sem doença evoluíram com dosagens séricas de CEA dentro dos limites da normalidade, mas nove pacientes, que evoluíram com doença ativa, o fizeram em vigência de dosagens séricas normais de CEA.

Através de análise bivariada, não obtiveram correlação estatística com as evoluções clínicas finais dos pacientes estudados: faixas etárias ao diagnóstico, gênero e tipo de diagnóstico etiológico, se feito em momento pré ou pós-operatório, por achado acidental de USG cervical ou por rastreamento. Multicentricidade tumoral, presença de HCC e de amilóide no tecido neoplásico primário não foram determinantes de evoluções clínicas, assim como também não o foi extensão neoplásica para além dos limites dos linfonodos metastáticos, embora nenhum paciente portador desta variável tenha alcançado cura. Presença de metástases a distância, ao diagnóstico, também não teve relação estatisticamente significativa com condição clínica final, embora a análise tenha sido prejudicada pela presença de apenas um paciente sob esta variável, paciente que faleceu pela doença. Formas clínicas de CMT e elevação de títulos séricos de CEA, juntamente com a progressão da neoplasia, não exerceram influência sobre a condição clínica final, enquanto que 
níveis séricos de CT e CEA não puderam ser estatisticamente correlacionados com evolução clínica, devido à presença de ocorrências nulas ou muito baixas. Já, quando os pacientes foram agrupados em portadores de doença cervical, portadores de neoplasia metastática à distância, portadores de neoplasias cervical e a distância e portadores somente de doença bioquímica (quatro grupos), notou-se correlação estatística quanto ao tipo de evolução final do paciente, ou seja, vivo com doença ou morto pela doença (Tabela 26).

Tabela 19 - Avaliação de condição clínica final segundo as variáveis: faixa etária e gênero

\begin{tabular}{|c|c|c|c|c|c|c|c|c|c|}
\hline \multirow{3}{*}{ VARIÁVEL } & \multicolumn{6}{|c|}{ CONDIÇÃO CLÍNICA } & & & \multirow{3}{*}{ Valor de $\mathrm{p}$} \\
\hline & \multicolumn{2}{|c|}{ VSD } & \multicolumn{2}{|c|}{ VCD } & \multicolumn{2}{|c|}{ MCD } & \multicolumn{2}{|c|}{ TOTAL } & \\
\hline & $\mathrm{N}$ & $\%$ & $\mathrm{~N}$ & $\%$ & $\mathrm{~N}$ & $\%$ & $\mathrm{~N}$ & $\%$ & \\
\hline \multicolumn{10}{|l|}{ - Faixa etária (anos) } \\
\hline A - Até 20 & 6 & 60,0 & 4 & 40,0 & - & - & 10 & 100,0 & (1) $\mathrm{p}=0,1498$ \\
\hline B - 21 a 30 & - & - & 4 & 66,7 & 2 & 33,3 & 6 & 100,0 & \\
\hline$C-31$ a 40 & 4 & 57,1 & 3 & 42,9 & - & - & 10 & 100,0 & \\
\hline D - 41 a 50 & 3 & 30,0 & 6 & 60,0 & 1 & 10,0 & 10 & 100,0 & \\
\hline E - 51 ou mais & 2 & 50,0 & 1 & 25,0 & 1 & 25,0 & 4 & 100,0 & \\
\hline TOTAL & 15 & 40,5 & 18 & 48,7 & 4 & 10,8 & 37 & 100,0 & \\
\hline
\end{tabular}

\section{- Gênero}

Feminino
Masculino
TOTAL


Tabela 20 - Avaliação de condição clínica segundo as variáveis: diagnóstico préoperatório, diagnóstico como achado acidental de USG, diagnóstico por rastreamento, exame físico positivo (presença de nódulos tireóideos e/ou linfonodos cervicais palpáveis) e sintomas sistêmicos

\begin{tabular}{|c|c|c|c|c|c|c|c|c|c|}
\hline \multirow{3}{*}{ VARIÁVEL } & \multicolumn{6}{|c|}{ CONDIÇÃO CLÍNICA } & \multirow{2}{*}{\multicolumn{2}{|c|}{ TOTAL }} & \multirow{3}{*}{$\begin{array}{c}\text { Valor de } \\
\mathrm{p}\end{array}$} \\
\hline & \multicolumn{2}{|c|}{ VSD } & \multicolumn{2}{|c|}{ VCD } & \multicolumn{2}{|c|}{ MCD } & & & \\
\hline & $\mathrm{N}$ & $\%$ & $\mathrm{~N}$ & $\%$ & $\mathrm{~N}$ & $\%$ & $\mathrm{~N}$ & $\%$ & \\
\hline \multicolumn{10}{|l|}{ - Diagnóstico pré-operatório } \\
\hline $\operatorname{Sim}$ & 10 & 37,0 & 14 & 51,9 & 3 & 11,1 & 27 & 100,0 & ${ }^{(1)} \mathrm{p}=$ \\
\hline Não & 5 & 50,0 & 4 & 40,0 & 1 & 10,0 & 10 & 100,0 & 0,8657 \\
\hline TOTAL & 15 & 40,5 & 18 & 48,7 & 4 & 10,8 & 37 & 100,0 & \\
\hline
\end{tabular}

- Diagnóstico como achado acidental de USG

$\begin{array}{lccccccccc}\text { Sim } & 2 & 66,7 & 1 & 33,3 & - & - & 3 & 100,0 & { }^{(1)} \mathrm{p}= \\ \text { Não } & 13 & 38,2 & 17 & 50,0 & 4 & 11,8 & 34 & 100,0 & 0,7046 \\ \text { TOTAL } & 15 & 40,5 & 18 & 48,7 & 4 & 10,8 & 37 & 100,0 & \\ & & & & & & & & & \\ \text { - Diagnóstico por rastreamento familiar } & & & & & & & & & \\ \text { Sim } & 7 & 53,8 & 5 & 38,5 & 1 & 7,7 & 13 & 100,0 & { }^{(1)} \mathrm{p}= \\ \text { Não } & 8 & 33,3 & 13 & 54,2 & 3 & 12,5 & 24 & 100,0 & 0,4820 \\ \text { TOTAL } & 15 & 40,5 & 18 & 48,7 & 4 & 10,8 & 37 & 100,0 & \end{array}$

- Exame físico inicial positivo

$\begin{array}{lccccccccc}\text { Sim } & 8 & 26,7 & 18 & 60,0 & 4 & 13,3 & 30 & 100,0 & { }^{(1)} \mathrm{p}= \\ \text { Não } & 7 & 100,0 & - & - & - & - & 7 & 100,0 & 0,0017^{*} \\ \text { TOTAL } & 15 & 40,5 & 18 & 48,7 & 4 & 10,8 & 37 & 100,0 & \end{array}$

- Sintomas sistêmicos

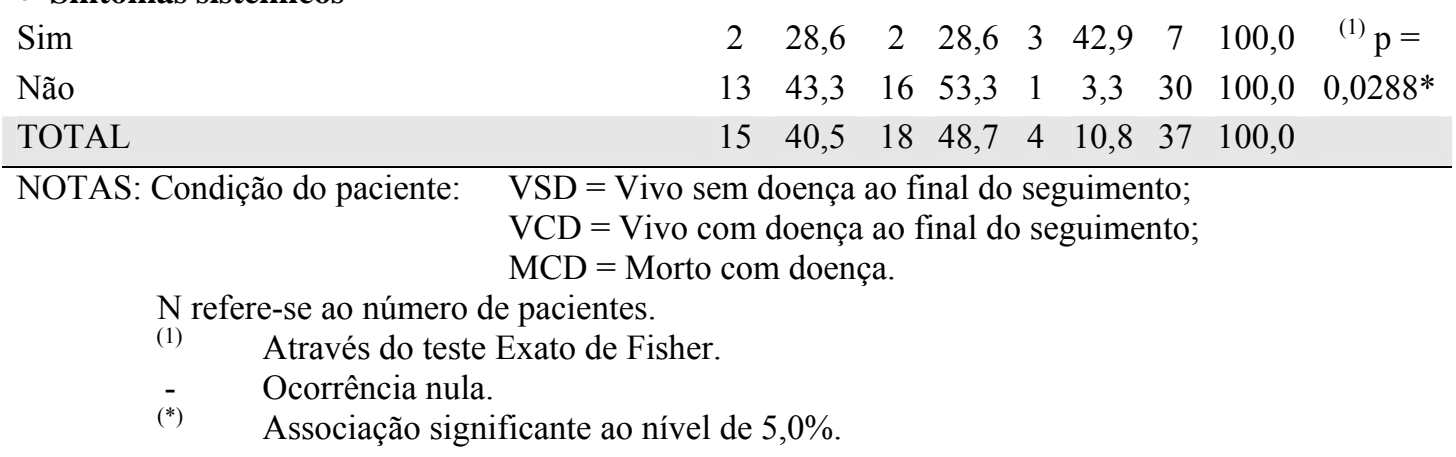


Tabela 21 - Avaliação de condição clínica final segundo as variáveis: faixa de maior diâmetro tumoral $(\mathrm{mm})$, multicentricidade tumoral, extensão para a cápsula tireóidea, extensão para tecidos adjacentes, invasão vascular e presença de $\mathrm{HCC}$

\begin{tabular}{|c|c|c|c|c|c|c|c|c|c|}
\hline \multirow{3}{*}{ VARIÁVEL } & \multicolumn{6}{|c|}{ CONDIÇÃO CLÍNICA } & \multirow{2}{*}{\multicolumn{2}{|c|}{ TOTAL }} & \multirow{3}{*}{ Valor de $\mathrm{p}$} \\
\hline & \multicolumn{2}{|c|}{ VSD } & \multicolumn{2}{|c|}{ VCD } & \multicolumn{2}{|c|}{ MCD } & & & \\
\hline & $\mathrm{N}$ & $\%$ & $\mathrm{~N}$ & $\%$ & $\mathrm{~N}$ & $\%$ & $\mathrm{~N}$ & $\%$ & \\
\hline
\end{tabular}

- Faixa de maior diâmetro tumoral (mm)

$\begin{array}{lccccccccc}\text { A - Até } 5 & 3 & 100,0 & - & - & - & - & 3 & 100,0 & { }^{(1)} \mathrm{p}=0,0502 \\ \mathrm{~B}->5 \mathrm{e}<15 & 5 & 55,6 & 4 & 44,4 & - & - & 9 & 100,0 & \\ \mathrm{C}-\geq 15 \mathrm{e}<30 & 1 & 10,0 & 8 & 80,0 & 1 & 10,0 & 10 & 100,0 & \\ \mathrm{D}-\geq 30 & 5 & 38,5 & 5 & 38,5 & 3 & 23,1 & 13 & 100,0 & \\ \text { TOTAL } & 14 & 40,0 & 17 & 48,6 & 4 & 11,4 & 35 & 100,0\end{array}$

\section{- Multicentricidade} tumoral

$\begin{array}{lccccccccc}\text { Sim } & 7 & 33,3 & 12 & 57,1 & 2 & 9,5 & 21 & 100,0 & { }^{(1)} \mathrm{p}=0,7631 \\ \text { Não } & 7 & 50,0 & 6 & 42,9 & 1 & 7,1 & 14 & 100,0 & \\ \text { TOTAL } & 14 & 40,0 & 18 & 51,4 & 3 & 8,6 & 35 & 100,0 & \end{array}$

\section{- Extensão para cápsula} tireóidea

$\begin{array}{lccccccccc}\text { Sim } & 2 & 15,4 & 8 & 61,5 & 3 & 23,1 & 13 & 100,0 & \text { (1) } \mathrm{p}=0,0375^{*} \\ \text { Não } & 13 & 54,2 & 10 & 41,7 & 1 & 4,2 & 24 & 100,0 & \\ \text { TOTAL } & 15 & 40,5 & 18 & 48,7 & 4 & 10,8 & 37 & 100,0 & \end{array}$

\section{- Extensão para tecidos} adjacentes

$\begin{array}{lccccccccc}\text { Sim } & - & - & 2 & 40,0 & 3 & 60,0 & 5 & 100,0 & { }^{(1)} \mathrm{p}=0,0024^{*} \\ \text { Não } & 15 & 46,9 & 16 & 50,0 & 1 & 3,1 & 32 & 100,0 & \\ \text { TOTAL } & 15 & 40,5 & 18 & 48,7 & 4 & 10,8 & 37 & 100,0 & \end{array}$

\section{- Invasão vascular}

$\begin{array}{lccccccccc}\text { Sim } & 1 & 11,1 & 7 & 77,8 & 1 & 11,1 & 9 & 100,0 & { }^{(1)} \mathrm{p}=0,0142^{*} \\ \text { Não } & 9 & 69,2 & 4 & 30,8 & - & - & 13 & 100,0 & \\ \text { TOTAL } & 10 & 45,5 & 11 & 50,0 & 1 & 4,5 & 22 & 100,0 & \end{array}$

- Presença de HCC

\begin{tabular}{lccccccccc} 
Sim & 6 & 40,0 & 8 & 53,3 & 1 & 6,7 & 15 & 100,0 & ${ }^{(1)} \mathrm{p}=1,0000$ \\
Não & 4 & 36,4 & 6 & 54,5 & 1 & 9,1 & 11 & 100,0 & \\
TOTAL & 10 & 38,5 & 14 & 53,8 & 2 & 7,7 & 26 & 100,0 & \\
\hline
\end{tabular}

NOTAS: N refere-se ao número de pacientes.

Condição do paciente: $\quad$ VSD $=$ Vivo sem doença ao final do seguimento; $\mathrm{VCD}=$ Vivo com doença ao final do seguimento; $\mathrm{MCD}=$ Morto com doença.

(1) Através do teste Exato de Fisher.

(*) Associação significante ao nível de 5,0\%.

- $\quad$ Ocorrência nula. 
Tabela 22 - Avaliação de condição clínica final segundo as variáveis: presença de amilóide em tumor primário, linfonodos cervicais acometidos pela neoplasia, extensão neoplásica capsular linfonodal, metástases a distância e estádio patológico (TNM)

\begin{tabular}{|c|c|c|c|c|c|c|c|c|c|}
\hline \multirow{3}{*}{ VARIÁVEL } & \multicolumn{6}{|c|}{ CONDIÇÃO CLÍNICA } & & & \multirow{3}{*}{ Valor de $\mathrm{p}$} \\
\hline & \multicolumn{2}{|c|}{ VSD } & \multicolumn{2}{|c|}{ VCD } & \multicolumn{2}{|c|}{ MCD } & \multicolumn{2}{|c|}{ TOTAL } & \\
\hline & $\mathrm{N}$ & $\%$ & $\mathrm{~N}$ & $\%$ & $\mathrm{~N}$ & $\%$ & $\mathrm{~N}$ & $\%$ & \\
\hline \multicolumn{10}{|c|}{ - Presença de amilóide } \\
\hline Sim & 8 & 38,1 & 11 & 52,4 & 2 & 9,5 & 21 & 100,0 & ${ }^{(1)} \mathrm{p}=0,8979$ \\
\hline Não & 7 & 43,7 & 7 & 43,7 & 2 & 12,5 & 16 & 100,0 & \\
\hline TOTAL & 15 & 40,5 & 18 & 48,7 & 4 & 10,8 & 37 & 100,0 & \\
\hline
\end{tabular}

- Metástases linfonodais

$\begin{array}{lccccccccc}\text { Sim } & 2 & 9,5 & 15 & 71,4 & 4 & 19,1 & 21 & 100,0 & { }^{(1)} \mathrm{p}<0,0001^{*} \\ \text { Não } & 13 & 81,3 & 3 & 18,7 & - & - & 16 & 100,0 & \\ \text { TOTAL } & 15 & 40,5 & 18 & 48,7 & 4 & 10,8 & 37 & 100,0 & \end{array}$

\section{- Extensão capsular}

$\begin{array}{lccccccccc}\text { Sim } & - & - & 7 & 70,0 & 3 & 30,0 & 10 & 100,0 & { }^{(1)} \mathrm{p}=0,3270 \\ \text { Não } & 2 & 18,2 & 8 & 72,7 & 1 & 9,1 & 11 & 100,0 & \\ \text { TOTAL } & 2 & 9,5 & 15 & 71,4 & 4 & 19,0 & 21 & 100,0 & \end{array}$

$\begin{array}{lccccccccc}\text { - Metástases a distância } & & & & & & & & & \\ \text { Sim } & - & - & - & - & 1 & 2,7 & 1 & 100,0 & { }^{(1)} \mathrm{p}=0,1081 \\ \text { Não } & 15 & 41,7 & 18 & 50,0 & 3 & 8,3 & 36 & 100,0 & \\ \text { TOTAL } & 15 & 40,5 & 18 & 48,7 & 4 & 10,8 & 37 & 100,0 & \end{array}$

\section{• Estádio TNM}

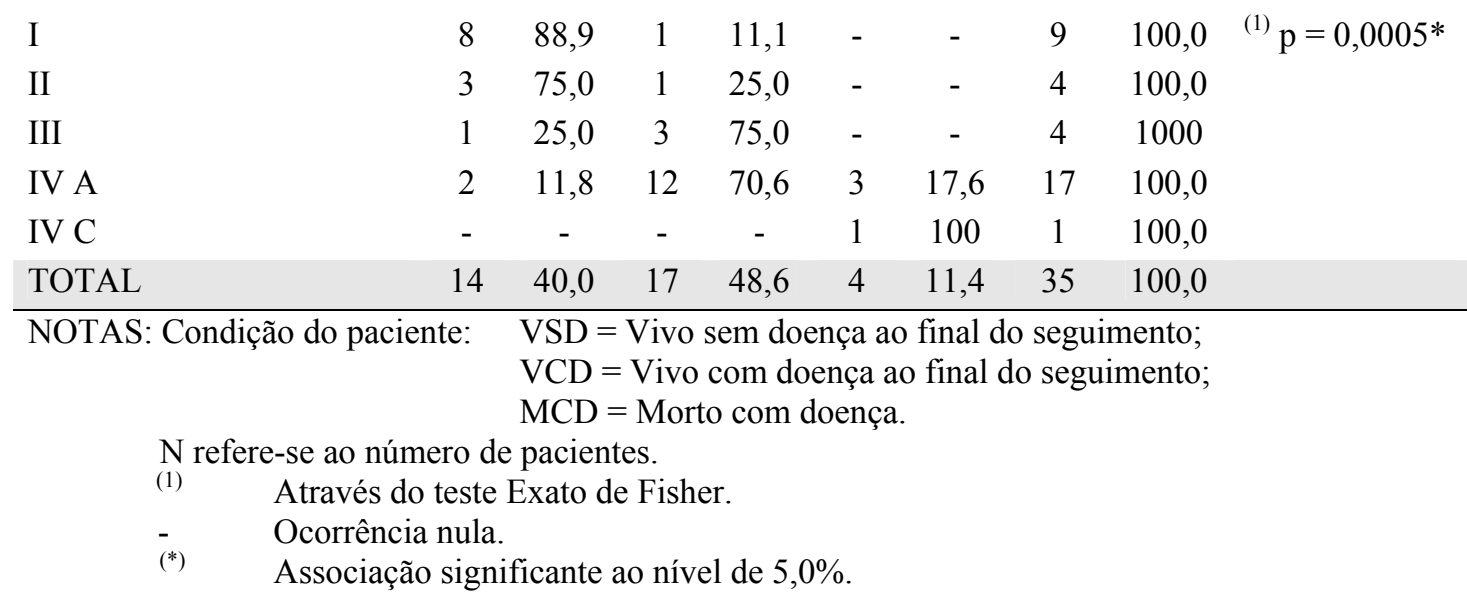


Tabela 23 - Avaliação de condição clínica final segundo as formas de doença: esporádica ou familiar

\begin{tabular}{|c|c|c|c|c|c|c|c|c|c|}
\hline \multirow{3}{*}{ FORMA DE DOENÇA } & \multicolumn{6}{|c|}{ CONDIÇÃO CLÍNICA } & & & \multirow{3}{*}{ Valor de $\mathrm{p}$} \\
\hline & \multicolumn{2}{|c|}{ VSD } & \multicolumn{2}{|c|}{ VCD } & \multicolumn{2}{|c|}{ MCD } & \multicolumn{2}{|c|}{ TOTAL } & \\
\hline & $\mathrm{N}$ & $\%$ & $\mathrm{~N}$ & $\%$ & $\mathrm{~N}$ & $\%$ & $\mathrm{~N}$ & $\%$ & \\
\hline Esporádica & 8 & 38,1 & 10 & 47,6 & 3 & 14,3 & 21 & 100,0 & ${ }^{(1)} \mathrm{p}=0,8025$ \\
\hline Familiar & 7 & 43,7 & 8 & 50,0 & 1 & 6,3 & 16 & 100,0 & \\
\hline TOTAL & 15 & 40,5 & 18 & 48,7 & 4 & 10,8 & 37 & 100,0 & \\
\hline NOTAS: Condição do paci & & $\begin{array}{l}\mathrm{VSD}= \\
\mathrm{VCD} \\
\mathrm{MCD}\end{array}$ & $\begin{array}{l}\text { Vivo } \\
\text { Vive } \\
\text { Mol }\end{array}$ & $\begin{array}{l}\text { em do } \\
\text { com d } \\
\text { com }\end{array}$ & ca & $\begin{array}{l}\text { final } \\
\text { final }\end{array}$ & seg & $\begin{array}{l}\text { nento; } \\
\text { mento; }\end{array}$ & \\
\hline
\end{tabular}

Tabela 24 - Avaliação de condição clínica final segundo as variáveis: títulos séricos iniciais de CT (valores relativos, em relação aos máximos valores laboratoriais de referência) e no seguimento clínico (valores relativos também, segundo dosagem de maior valor)

\begin{tabular}{|c|c|c|c|c|c|c|c|c|c|}
\hline \multirow{3}{*}{ VARIÁVEL } & \multicolumn{6}{|c|}{ CONDIÇÃO CLÍNICA } & & & \multirow{3}{*}{ Valor de $\mathrm{p}$} \\
\hline & \multicolumn{2}{|c|}{ VSD } & \multicolumn{2}{|c|}{ VCD } & \multicolumn{2}{|c|}{ MCD } & \multicolumn{2}{|c|}{ TOTAL } & \\
\hline & $\mathrm{N}$ & $\%$ & $\mathrm{~N}$ & $\%$ & $\mathrm{~N}$ & $\%$ & $\mathrm{~N}$ & $\%$ & \\
\hline \multicolumn{10}{|l|}{ - CT - inicial } \\
\hline Normal a 3 vezes & 4 & 80,0 & 1 & 20,0 & - & - & 5 & 100,0 & $* *$ \\
\hline$>3$ a 10 vezes & 3 & 60,0 & 1 & 20,0 & 1 & 20,0 & 5 & 100,0 & \\
\hline$>10$ a 30 vezes & 1 & 14,3 & 3 & 57,1 & 2 & 28,6 & 7 & 100,0 & \\
\hline$>30$ a 100 vezes & 1 & 20,0 & 4 & 80,0 & - & - & 5 & 100,0 & \\
\hline$>100$ vezes & - & - & 4 & 100,0 & - & - & 4 & 100,0 & \\
\hline TOTAL & 9 & 34,6 & 14 & 53,9 & 3 & 11,5 & 26 & 100,0 & \\
\hline
\end{tabular}

- CT - evolução

Normal

3 a 10 vezes

$>10$ a 30 vezes

$>30$ a 100 vezes

$>100$ vezes

TOTAL

NOTAS: Condição do paciente:

$\mathrm{N}$ refere-se ao número de pacientes.

$\begin{array}{cccccccc}15 & 100,0 & - & - & - & - & 15 & 100,0 \\ - & - & 4 & 100,0 & - & - & 4 & 100,0 \\ - & - & 4 & 100,0 & - & - & 4 & 100,0 \\ - & - & 2 & 100,0 & - & - & 2 & 100,0 \\ - & - & 8 & 72,7 & 3 & 27,3 & 11 & 100,0 \\ 15 & 41,7 & 18 & 50,0 & 3 & 8,3 & 36 & 100,0\end{array}$

VSD = Vivo sem doença ao final do seguimento;

$\mathrm{VCD}=$ Vivo com doença ao final do seguimento;

$\mathrm{MCD}=$ Morto com doença.

- Ocorrência nula.

muito baixas. 
Tabela 25 - Avaliação de condição clínica final segundo as variáveis: CEA (valores séricos relativos, em relação aos máximos valores laboratoriais de referência, ao diagnóstico ou pós-operatório imediato e durante a evolução) e se CEA elevou-se, acompanhando a progressão da doença (portadores de persistências ou recidivas), ou não

\begin{tabular}{|c|c|c|c|c|c|c|c|c|c|}
\hline \multirow{3}{*}{ VARIÁVEL } & \multicolumn{6}{|c|}{ CONDIÇÃO CLÍNICA } & & & \multirow{3}{*}{ Valor de $\mathrm{p}$} \\
\hline & \multicolumn{2}{|c|}{ VSD } & \multicolumn{2}{|c|}{ VCD } & \multicolumn{2}{|c|}{ MCD } & \multicolumn{2}{|c|}{ TOTAL } & \\
\hline & $\mathrm{N}$ & $\%$ & $\mathrm{~N}$ & $\%$ & $\mathrm{~N}$ & $\%$ & $\mathrm{~N}$ & $\%$ & \\
\hline \multicolumn{10}{|l|}{ - CEA - inicial } \\
\hline Normal & 3 & 50,0 & 2 & 33,3 & 1 & 16,7 & 6 & 100,0 & $*$ \\
\hline$>1$ a 3 vezes & - & - & 3 & 75,0 & 1 & 25,0 & 4 & 100,0 & \\
\hline$>3$ a 10 vezes & 1 & 33,3 & 2 & 66,7 & - & - & 3 & 100,0 & \\
\hline$>10$ vezes & 2 & 40,0 & 2 & 40,0 & 1 & 20,0 & 5 & 100,0 & \\
\hline TOTAL & 6 & 33,3 & 9 & 50,0 & 3 & 16,7 & 18 & 100,0 & \\
\hline
\end{tabular}

- CEA normal evolução

$\begin{array}{lccccccccc}\text { Sim } & 13 & 59,1 & 8 & 36,4 & 1 & 4,5 & 22 & 100,0 & { }^{(1)} \mathrm{p}=0,0022^{* *} \\ \text { Não } & - & - & 8 & 80,0 & 2 & 20,0 & 10 & 100,0 & \\ \text { TOTAL } & 13 & 40,6 & 16 & 50,0 & 3 & 9,4 & 32 & 100,0\end{array}$

- CEA elevou-se junto com a progressão da doença

$\begin{array}{lccccccccc}\text { Sim } & - & - & 8 & 80,0 & 2 & 20,0 & 10 & 100,0 & { }^{(1)} \mathrm{p}=1,0000 \\ \text { Não } & - & - & 8 & 88,9 & 1 & 11,1 & 9 & 100,0 & \\ \text { TOTAL }^{(2)} & & & 16 & 84,2 & 3 & 15,8 & 19 & 100,0\end{array}$

NOTAS: Condição do paciente: $\quad$ VSD = Vivo sem doença ao final do seguimento; $\mathrm{VCD}=$ Vivo com doença ao final do seguimento; $\mathrm{MCD}=$ Morto com doença.

$\mathrm{N}$ refere-se ao número de pacientes.

${ }^{(*)} \quad$ O teste estatístico não foi obtido devido ao elevado número de freqüências nulas ou muito baixas.

(**) Associação significante ao nível de 5,0\%.

(1) Através do teste Exato de Fisher.

- Ocorrência nula.

(2) Exclusão de vivos e sem doença. 
Tabela 26 - Avaliação de condição clínica segundo o tipo de progressão do CMT: pacientes cujas doenças persistiram ou apresentaram recidivas, somente bioquímica, cervical, a distância ou cervical e a distância

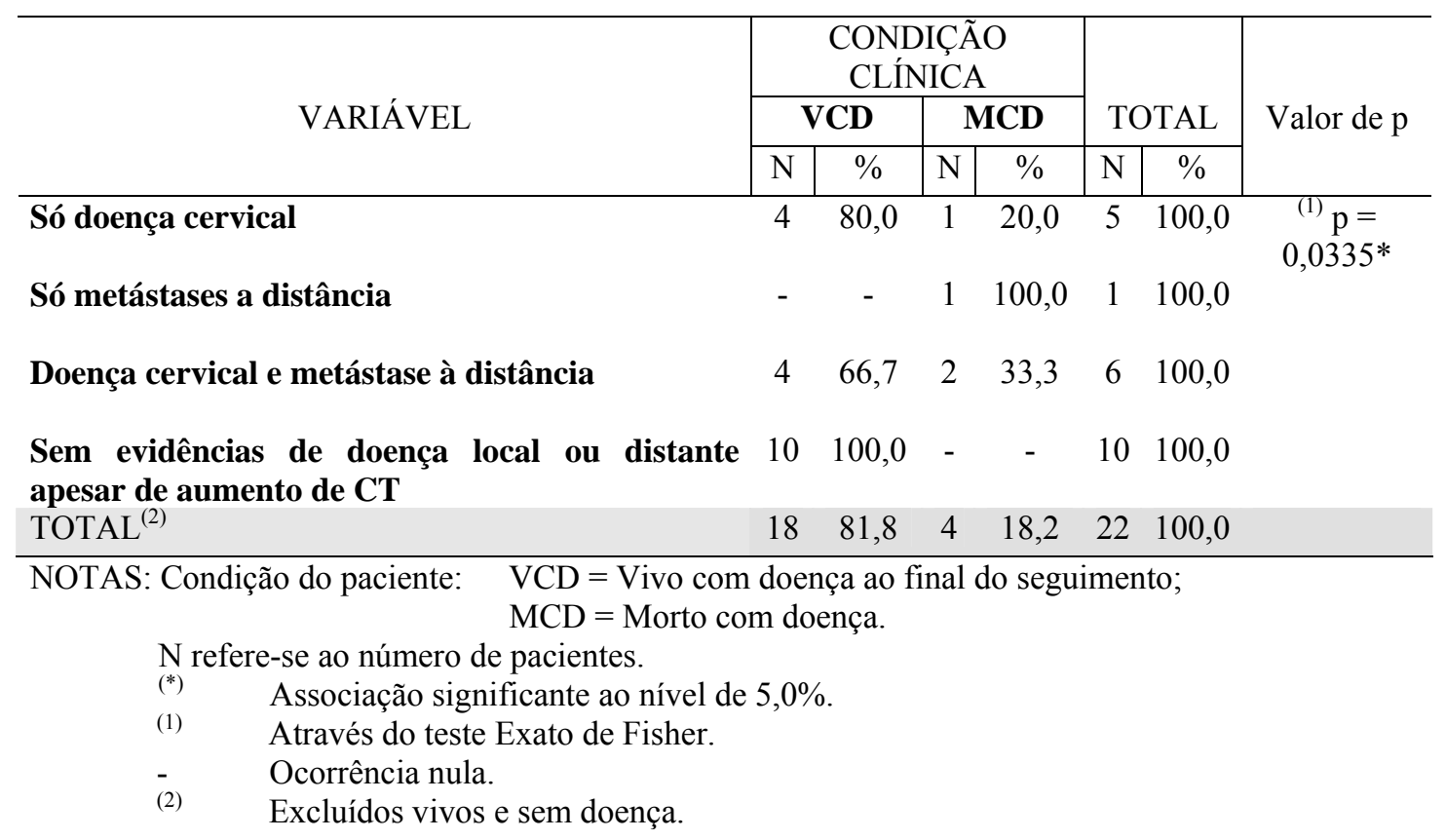

Na Tabela 27, estão demonstrados dados clinicopatológicos avaliados anteriormente, mas que não apresentaram correlações estatísticas com as condições clínicas finais. Foram, então, distribuídos em função das evoluções clínicas segundo pacientes que se curaram (15 casos) e aqueles cujas neoplasias persistiram ou recidivaram (22 casos). Encontrou-se significância estatística, quanto à evolução, à análise das variáveis: faixa de maior diâmetro tumoral $(\mathrm{p}=0,0249)$ e títulos séricos de CT, relativos aos máximos valores laboratoriais de referência, ao diagnóstico ou momento pós-operatório imediato $(\mathrm{p}=0,0476)$. Riscos relativos $(\mathrm{RR})$ também foram calculados para cada variável.

Faixa etária, gênero, multicentricidade tumoral, forma clínica da doença, presenças de amilóide e HCC nos espécimes neoplásicos, além de títulos séricos iniciais de CEA, novamente não interferiram, segundo análise estatística, no tipo de evolução clínica observada. 
Tabela 27 - Avaliação de evolução clínica (persistência ou recidiva neoplásicas e cura) segundo as variáveis: faixa etária, gênero, forma clínica da doença, diâmetro e multicentricidade tumorais, presenças de $\mathrm{HCC}$ e amilóide e CT e CEA séricos relativos e iniciais

\begin{tabular}{|c|c|c|c|c|c|c|c|c|}
\hline \multirow{3}{*}{ VARIÁVEL } & \multicolumn{4}{|c|}{ EVOLUÇÃO } & & & \multirow{3}{*}{$\begin{array}{c}\text { Valor de } \\
\mathrm{p}\end{array}$} & \multirow{3}{*}{$\begin{array}{l}\text { RR (IC } \\
95,0 \%)\end{array}$} \\
\hline & \multicolumn{2}{|c|}{ Persistência/Recidiva } & \multicolumn{2}{|c|}{ Cura } & \multicolumn{2}{|c|}{ TOTAL } & & \\
\hline & $\mathrm{N}$ & $\%$ & $\mathrm{~N}$ & $\%$ & $\mathrm{~N}$ & $\%$ & & \\
\hline
\end{tabular}

- Faixa etária (anos)

$\begin{array}{lccccccc}\text { A - Até } 20 & 4 & 40,0 & 6 & 60,0 & 10 & 100,0 & { }^{(1)} \mathrm{p}= \\ \text { B - 21 a 30 } & 6 & 100,0 & - & - & 6 & 100,0 & 0,1255 \\ \text { C - 31 a } 40 & 3 & 42,9 & 4 & 57,1 & 7 & 100,0 & \\ \text { D - 41 a 50 } & 7 & 70,0 & 3 & 30,0 & 10 & 100,0 & \\ \text { E - } \geq 51 & 2 & 50,0 & 2 & 50,0 & 4 & 100,0 & \\ \text { TOTAL } & 22 & 59,5 & 15 & 40,5 & 37 & 100,0 & \end{array}$

- Gênero

Feminino 17

Masculino

5

70,8

$\begin{array}{llll}7 & 29,2 & 24 & 100,0\end{array}$

${ }^{(1)} \mathrm{p}=$

1,84

TOTAL

22

38,5

59 ,

$\begin{array}{llll}8 & 61,5 & 13 & 100,0\end{array}$

0,0829

$(0,88$ a

- Forma clínica

da doença

Esporádica

13

Familiar

9

TOTAL

22

$61,9 \quad 8 \quad 38,1 \quad 21 \quad 100,0$

${ }^{(1)} \mathrm{p}=$

1,10

$(0,34 \mathrm{a}$

TOTAL

$\begin{array}{ccccc}56,3 & 7 & 43,7 & 16 & 100,0 \\ 59,5 & 15 & 40,5 & 37 & 100,0\end{array}$

0,7285

$4,75)$

\section{- Diâmetro}

\section{tumoral (mm)}

\section{A - Até 5}

$\mathrm{B}->5 \mathrm{e}<15$

C $-\geq 15$ e $<30$

$\mathrm{E}-\geq 30$

22

$\begin{array}{lllll}59,5 & 15 & 40,5 & 37 & 100,0\end{array}$

TOTAL

$\begin{array}{ccccc}- & 3 & 100,0 & 3 & 100,0 \\ 44,4 & 5 & 55,6 & 9 & 100,0 \\ 90,0 & 1 & 10,0 & 10 & 100,0 \\ 61,5 & 5 & 38,5 & 13 & 100,0 \\ 60,0 & 14 & 40,0 & 35 & 100,0\end{array}$

- Multicentricidade tumoral

$\begin{array}{lcccccccc}\text { Sim } & 14 & 66,7 & 7 & 33,3 & 21 & 100,0 & { }^{(2)} \mathrm{p}= & \begin{array}{c}1,33 \\ (0,73 \mathrm{a}\end{array} \\ \text { Não } & 7 & 50,0 & 7 & 50,0 & 14 & 100,0 & 0,3241 & 2,44) \\ \text { TOTAL } & 21 & 60,0 & 14 & 40,0 & 35 & 100,0 & & \end{array}$


Conclusão- $\quad$ Tabela 27

\begin{tabular}{|c|c|c|c|c|c|c|c|c|}
\hline \multirow{3}{*}{ VARIÁVEL } & \multicolumn{4}{|c|}{ EVOLUÇÃO } & \multirow{2}{*}{\multicolumn{2}{|c|}{ TOTAL }} & \multirow{3}{*}{$\begin{array}{c}\text { Valor de } \\
p\end{array}$} & \multirow{3}{*}{$\begin{array}{l}\text { RR (IC } \\
95,0 \%)\end{array}$} \\
\hline & \multicolumn{2}{|c|}{ Persistência/Recidiva } & \multicolumn{2}{|c|}{ Cura } & & & & \\
\hline & $\mathrm{N}$ & $\%$ & $\mathrm{~N}$ & $\%$ & $\mathrm{~N}$ & $\%$ & & \\
\hline
\end{tabular}

\section{- Presença de \\ HCC}

$\begin{array}{lcccccccc}\text { Sim } & 9 & 60,0 & 6 & 40,0 & 15 & 100,0 & { }^{(1)} \mathrm{p}= & 0,94(0,51 \mathrm{a} \\ \text { Não } & 7 & 63,6 & 4 & 36,4 & 11 & 100,0 & 1,0000 & 1,73) \\ \text { TOTAL } & 16 & 61,5 & 10 & 38,5 & 26 & 100,0 & & \end{array}$

- Presença de amilóide

$\begin{array}{lcccccccc}\text { Sim } & 13 & 61,9 & 8 & 38,1 & 21 & 100,0 & { }^{(2)} \mathrm{p}= & 1,10(0,63 \mathrm{a} \\ \text { Não } & 9 & 56,3 & 7 & 43,7 & 16 & 100,0 & 0,7285 & 1,90) \\ \text { TOTAL } & 22 & 59,5 & 15 & 40,5 & 37 & 100,0 & & \end{array}$

\section{- CT - inicial}

Normal a 3 vezes

$>3$ a 10 vezes

$>10$ a 30 vezes

$>30$ a 100 vezes

$>100$ vezes

$\begin{array}{ccccccc}1 & 20,0 & 4 & 80,0 & 5 & 100,0 & { }^{(1)} \mathrm{p}= \\ 2 & 40,0 & 3 & 60,0 & 5 & 100,0 & 0,0476^{*} \\ 6 & 85,7 & 1 & 14,3 & 7 & 100,0 & \\ 4 & 80,0 & 1 & 20,0 & 5 & 100,0 & \\ 4 & 100,0 & - & - & 4 & 100,0 & \\ 17 & 65,4 & 9 & 34,6 & 26 & 100,0 & \end{array}$

- CEA - inicial

Normal

$>1$ a 3 vezes

$>3$ a 10 vezes

$50,0 \quad 3 \quad 50,0 \quad 6 \quad 100,0 \quad{ }^{(1)} \mathrm{p}=$

$>10$ vezes

3

4

2

TOTAL

3

$100,0 \quad-\quad-\quad 4 \quad 4 \quad 100,0 \quad 0,4899$

$\begin{array}{lllll}66,7 & 1 & 33,3 & 3 & 100,0\end{array}$

$\begin{array}{lllll}60,0 & 2 & 40,0 & 5 & 100,0\end{array}$

NOTAS: RR e IC referem-se a risco relativo e intervalo de confiança para o referido parâmetro, respectivamente.
$\mathrm{N}$ refere-se ao número de pacientes.
(1) Através do teste Exato de Fisher.
${ }^{*}$ Associação significante ao nível de 5,0\%.
$(* *) \quad$ Não pode ser determinado devido a ocorrência de freqüência nula.
(2) Através do teste Qui-quadrado. 


\subsection{ANÁLISE ESTATÍSTICA DAS VARIÁVEIS RELACIONADAS À MARCAÇÃO MMP-2}

Para análise estatística das relações entre imunocoloração para MMP-2 e condição clínica, ao final dos seguimentos, bem como evolução após o tratamento operatório inicial, os pacientes cujos "Índices" de marcação foram identificados como " 1 " ou "2" foram agrupados em um único segmento de casos, para que fossem comparados com aqueles cujas lesões neoplásicas estudadas haviam sido classificadas como "Índice 3", segundo seção "Métodos" deste trabalho. A grande maioria das áreas tumorais imunomarcadas para MMP-2 o foram de forma intensa, de tal forma que todos os espécimes analisados, quanto à intensidade de coloração do marcador, foram considerados "Índice 3".

Quanto às possíveis condições clínicas ao final dos seguimentos (vivo sem doença, vivo com doença ou morto pela doença), foram observadas relações estatisticamente significativas com variável que associou proporção de área tumoral primária imunocorada e intensidade de coloração, denominada "índice geral para o tumor primário" ( $\mathrm{p}=0,0005$, Tabela 28$)$. A proporção de área imunomarcada no tumor primário não apresentou, após cálculos estatísticos, associação com condições clínicas finais $(\mathrm{p}=0,0794)$, mas observou-se tendência à significância estatística, como expõe a mesma Tabela 28. Cálculos relativos à correlação da intensidade de marcação IH dos espécimes neoplásicos com condições clínicas finais não puderam ser realizados, uma vez que todas as marcações foram agrupadas sob um mesmo índice. 
Tabela 28 - Avaliação de condição clínica final segundo as variáveis relativas à imunocoloração para MMP-2: proporção de área marcada em tumor primário, intensidade de marcação em tumor primário, proporção de área marcada em metástase linfonodal, intensidade da marcação em metástase linfonodal, índice geral para tumor primário e índice geral para metástase linfonodal, segundo sistema de índices proposto na seção "Métodos" e após aglutinação dos casos "Índices 1" e "2"

\begin{tabular}{|c|c|c|c|c|c|c|c|c|c|}
\hline \multirow{3}{*}{$\begin{array}{c}\text { VARIÁVEL } \\
\text { MMP-2 } \\
\end{array}$} & \multicolumn{6}{|c|}{ CONDIÇÃO CLÍNICA } & & & \multirow{3}{*}{$\begin{array}{c}\text { Valor de } \\
\mathrm{p}\end{array}$} \\
\hline & \multicolumn{2}{|c|}{ VSD } & \multicolumn{2}{|c|}{ VCD } & \multicolumn{2}{|c|}{ MCD } & \multicolumn{2}{|c|}{ TOTAL } & \\
\hline & $\mathrm{N}$ & $\%$ & $\mathrm{~N}$ & $\%$ & $\mathrm{~N}$ & $\%$ & $\mathrm{~N}$ & $\%$ & \\
\hline
\end{tabular}

\section{- Proporção de área marcada em tumor} primário

$\begin{array}{lcccccccccc}1 \text { ou } 2 & 14 & 51,9 & 10 & 37,0 & 3 & 11,1 & 27 & 100,0 & { }^{(1)} \mathrm{p}= \\ 3 & 1 & 11,1 & 7 & 77,8 & 1 & 11,1 & 9 & 100,0 & 0,0794 \\ \text { TOTAL }^{(2)} & 15 & 41,7 & 17 & 47,2 & 4 & 11,1 & 36 & 100,0 & \end{array}$

\section{- Intensidade de marcação em tumor primário \\ 1 ou 2 \\ 3}

TOTAL $^{(2)}$ $\begin{array}{llllllll}15 & 41,7 & 17 & 47,2 & 4 & 11,1 & 36 & 100,0\end{array}$

$\begin{array}{llllllll}15 & 41,7 & 17 & 47,2 & 4 & 11,1 & 36 & 100,0\end{array}$

- Proporção de área marcada em metástase linfonodal

$\begin{array}{lccccccccc}\text { lou } 2 & 2 & 14,3 & 9 & 64,3 & 3 & 21,4 & 14 & 100,0 & { }^{(1)} \mathrm{p}= \\ 3 & - & - & 4 & 100,0 & - & - & 4 & 100,0 & 0,7196 \\ \text { TOTAL }^{(3)} & 2 & 11,1 & 13 & 72,2 & 3 & 16,7 & 18 & 100,0 & \end{array}$

\section{- Intensidade de marcação em metástase} linfonodal

1 ou 2 3

TOTAL $^{(3)}$

- Índice geral para tumor primário

1 ou 2

3

TOTAL $^{(2)}$
$13 \quad 68,4 \quad 4 \quad 21,1 \quad 2 \quad 10,5 \quad 19 \quad 100,0 \quad{ }^{(1)} \mathrm{p}=$

$\begin{array}{llllllllll}2 & 11,8 & 13 & 76,5 & 2 & 11,8 & 17 & 100,0 & 0,0005^{* *}\end{array}$

$\begin{array}{llllllll}15 & 41,7 & 17 & 47,2 & 4 & 11,1 & 36 & 100,0\end{array}$

- Índice geral para metástase linfonodal 1 ou 2 3

NOTAS: Condição do paciente: $\quad$ VSD = Vivo sem doença ao final do seguimento; $\mathrm{VCD}=$ Vivo com doença ao final do seguimento; $\mathrm{MCD}=$ Morto com doença.

$\mathrm{N}$ refere-se ao número de pacientes.

(1) Através do teste Exato de Fisher.

(2) Para um paciente não se dispões desta informação.

Ocorrência nula.

(*) Devido à ausência de uma das categorias não se aplica teste estatístico. 
Conclusão - Tabela 28 - NOTAS

(3) Total de pacientes com metástases linfonodais cervicais, exceto três para os quais não se dispõe desta informação.

(**) Associação significante ao nível de 5.0\%.

Foram correlacionadas as expressões IH de MMP-2, nos espécimes primários e metastáticos, com evolução clínica logo após o tratamento operatório inicial, a saber, cura ou persistência neoplásica. Pacientes cujas imunocolorações para seus espécimes tumorais foram classificados como "Índices 1" ou "2" também foram alocados em um único grupo para comparação com o grupo "Índice 3". Aqui valem as mesmas considerações feitas no parágrafo anterior, quanto à intensidade de coloração observada para o marcador MMP-2.

Novamente o "índice geral para o tumor primário” foi a única variável, entre aquelas estudadas quanto à expressão IH de MMP-2 nos espécimes em questão, que se correlacionou, através de análise estatística, com as evoluções clínicas imediatas $(\mathrm{p}=0,0207$, Tabela, 29).

Entre os quatro pacientes cujos tumores primários foram classificados como “Índice Geral 3" e suas metástases linfonodais cervicais como "Índice Geral 2", três estavam vivos e com doença ao final dos seguimentos e um faleceu pela doença. Aquele, cujo tumor primário foi classificado como "Índice Geral 2" e sua metástase linfonodal cervical como "Índice Geral 3", faleceu pela doença. Nos cinco pacientes os tumores foram persistentes após suas ressecções. Ocorrências muito pequenas em cada categoria impediram análise estatística confiável. 
Tabela 29 - Avaliação de evolução inicial (cura ou persistência) segundo as variáveis relativas à imunocoloração para MMP-2: proporção de área marcada em tumor primário, intensidade de marcação em tumor primário, proporção de área marcada em metástase linfonodal, intensidade de marcação em metástase linfonodal, índice geral para tumor primário e índice geral para metástase linfonodal, segundo sistema de índices proposto na seção "Métodos" e após aglutinação dos casos "Índices 1" e "2"

\begin{tabular}{|c|c|c|c|c|c|c|c|}
\hline \multirow{3}{*}{ VARIÁVEL } & \multicolumn{4}{|c|}{ EVOLUÇÃO } & & & \multirow{3}{*}{$\begin{array}{c}\text { Valor de } \\
\mathrm{p}\end{array}$} \\
\hline & \multicolumn{2}{|c|}{ Cura } & \multicolumn{2}{|c|}{ Persistência } & \multicolumn{2}{|c|}{ TOTAL } & \\
\hline & $\mathrm{N}$ & $\%$ & $\mathrm{~N}$ & $\%$ & $\mathrm{~N}$ & $\%$ & \\
\hline \multicolumn{8}{|c|}{ - Proporção de área marcada em tumor primário } \\
\hline 1 ou 2 & 17 & 63,0 & 10 & 37,0 & 27 & 100,0 & ${ }^{(1)} \mathrm{p}=$ \\
\hline 3 & 3 & 33,3 & 6 & 66,7 & 9 & 100,0 & 0,1461 \\
\hline TOTAL $^{(2)}$ & 20 & 55,6 & 16 & 44,4 & 36 & 100,0 & \\
\hline
\end{tabular}

- Intensidade de marcação em tumor primário

$\begin{array}{lcccccc}1 \text { ou } 2 & - & - & - & - & - & 100,0 \\ 3 & 20 & 55,6 & 16 & 44,4 & 36 & 100,0 \\ \text { TOTAL }^{(2)} & 20 & 55,6 & 16 & 44,4 & 36 & 100,0\end{array}$

- Proporção de área marcada em metástase linfonodal

$\begin{array}{lccccccc}1 \text { ou } 2 & 2 & 14,3 & 12 & 85,7 & 14 & 100,0 & { }^{(1)} \mathrm{p}= \\ 3 & 2 & 50,0 & 2 & 50,0 & 4 & 100,0 & 0,1971 \\ \text { TOTAL }^{(3)} & 4 & 22,2 & 14 & 77,8 & 18 & 100,0 & \end{array}$

- Intensidade de coloração em metástase linfonodal

1 ou 2

3

TOTAL $^{(3)}$ $\begin{array}{lllllll}2 & 50,0 & 2 & 50,0 & 4 & 100,0 & 0,1971\end{array}$

$\begin{array}{llllll}4 & 22,2 & 14 & 77,8 & 18 & 100,0\end{array}$

- Índice geral para tumor primário

$\begin{array}{lccccccc}1 \text { ou } 2 & 14 & 73,7 & 5 & 26,3 & 19 & 100,0 & { }^{(4)} \mathrm{p}= \\ 3 & 6 & 35,3 & 11 & 64,7 & 17 & 100,0 & 0,0207^{* *} \\ \text { TOTAL }^{(2)} & 20 & 55,6 & 16 & 44,4 & 36 & 100,0 & \end{array}$

- Índice geral para metástase linfonodal

\begin{tabular}{lccccccc}
1 ou 2 & 2 & 20,0 & 8 & 80,0 & 10 & 100,0 & ${ }^{(1)} \mathrm{p}=$ \\
3 & 2 & 25,0 & 6 & 75,0 & 8 & 100,0 & 1,0000 \\
TOTAL $^{(3)}$ & 4 & 22,2 & 14 & 77,8 & 18 & 100,0 & \\
\hline
\end{tabular}

NOTAS: N refere-se ao número de pacientes.

(1) Através do teste Exato de Fisher.

(2) Para um paciente não se dispõe desta informação. 
Conclusão - Tabela 29 - NOTAS

\author{
Ocorrência nula. \\ (*) Devido à ausência de uma das categorias não se aplica teste estatístico. \\ (3) Total de pacientes com metástases linfonodais cervicais, exceto três, para os quais \\ não se dispõe desta informação. \\ (4) Através do teste Qui-quadrado de Pearson \\ (**) Associação significante ao nível de 5.0\%.
}

\title{
5.7 ANÁLISE ESTATÍSTICA DAS VARIÁVEIS RELACIONADAS À MARCAÇÃO MT1-MMP
}

Através das tabelas seguintes (30 e 31), observa-se que os métodos propostos para quantificação e qualificação das imunomarcações de MT1-MMP nos espécimes estudados proporcionaram valores sem significância estatística quanto às condições clínicas finais, caracterizadas por vivo sem doença, vivo com doença e morto com doença. No entanto, observou-se significância estatística quando as mesmas variáveis foram comparadas àqueles pacientes que evoluíram com cura inicial e àqueles cujas neoplasias persistiram, apesar do tratamento cirúrgico instituído, quanto à proporção de células neoplásicas coradas pelo marcador $(\mathrm{p}=0,0098$, Tabela 31) e ao "índice geral” também para o tumor primário $(\mathrm{p}=0,0216$, Tabela 31$)$. Devido à pequena ocorrência de casos sob "Índices 1", estes foram alocados em conjunto aos componentes do grupo “Índice 2", para realização das análises estatísticas.

Para cinco espécimes primários "Índice Geral 3", as respectivas metástases foram classificadas como "Índice Geral 2", estando os pacientes vivos e com doença ao término dos seguimentos. Para um tumor “Índice Geral 3", sua lesão metastática correspondente foi classificada como "Índice Geral 1" e o paciente faleceu. 
Tabela 30 - Avaliação de condição clínica final segundo as variáveis relativas à imunocoloração para MT1-MMP: proporção de células marcadas em tumor primário, intensidade de marcação em tumor primário, proporção de células marcadas em metástases linfonodal, intensidade de marcação em metástase linfonodal, índice geral para tumor primário e índice geral para metástase linfonodal, segundo sistema de índices proposto na seção "Métodos" e após aglutinação dos casos "Índices 1 " e " 2 "

\begin{tabular}{|c|c|c|c|c|c|c|c|c|c|}
\hline \multirow{3}{*}{$\begin{array}{l}\text { VARIÁVEL } \\
\text { MT1-MMP }\end{array}$} & \multicolumn{6}{|c|}{ CONDIÇÃO CLÍNICA } & \multirow{2}{*}{\multicolumn{2}{|c|}{ TOTAL }} & \multirow{3}{*}{$\begin{array}{c}\text { Valor } \\
\text { de } \\
\text { p }\end{array}$} \\
\hline & \multicolumn{2}{|c|}{ VSD } & \multicolumn{2}{|c|}{ VCD } & \multicolumn{2}{|c|}{ MCD } & & & \\
\hline & $\mathrm{N}$ & $\%$ & $\mathrm{~N}$ & $\%$ & $\mathrm{~N}$ & $\%$ & $\mathrm{~N}$ & $\%$ & \\
\hline
\end{tabular}

\section{- Proporção de células marcadas em tumor} primário

$\begin{array}{lrrrrrrrrr}1 \text { ou } 2 & 6 & 60,0 & 4 & 40,0 & - & - & 10 & 100,0 & { }^{(1)} \mathrm{p}= \\ 3 & 8 & 32,0 & 13 & 52,0 & 4 & 16,0 & 25 & 100,0 & 0,2876 \\ \text { TOTAL }^{(2)} & 14 & 40,0 & 17 & 48,6 & 4 & 11,4 & 35 & 100,0 & \end{array}$

- Intensidade de marcação em tumor primário

$\begin{array}{lccccccccc}1 \text { ou } 2 & 3 & 33,3 & 6 & 66,7 & - & - & 9 & 100,0 & (1) \\ 3 & 11 & 42,3 & 11 & 42,3 & 4 & 15,4 & 26 & 100,0 & 0,4315 \\ \text { TOTAL }^{(2)} & 14 & 40,0 & 17 & 48,6 & 4 & 11,4 & 35 & 100,0 & \end{array}$

- Proporção de células marcadas em metástase linfonodal

$\begin{array}{lccccccccc}1 \text { ou } 2 & - & - & 5 & 83,3 & 1 & 16,7 & 6 & 100,0 & { }^{(1)} \mathrm{p}= \\ 3 & 2 & 14,3 & 10 & 71,4 & 2 & 14,3 & 14 & 100,0 & 1,0000 \\ \text { TOTAL }^{(3)} & 2 & 10,0 & 15 & 75,0 & 3 & 15,0 & 20 & 100,0 & \end{array}$
- Intensidade de marcação em metástase linfonodal

$\begin{array}{lccccccccc}1 \text { ou } 2 & - & - & 9 & 81,8 & 2 & 18,2 & 11 & 100,0 & { }^{(1)} \mathrm{p}= \\ 3 & 2 & 22,2 & 6 & 66,7 & 1 & 11,1 & 9 & 100,0 & 0,3615 \\ \text { TOTAL }^{(3)} & 2 & 10,0 & 15 & 75,0 & 3 & 15,0 & 20 & 100,0 & \end{array}$

- Índice geral para tumor primário

$\begin{array}{lccccccccc}1 \text { ou } 2 & 4 & 66,7 & 2 & 33,3 & - & - & 6 & 100,0 & (1) \mathrm{p}= \\ 3 & 10 & 34,5 & 15 & 51,7 & 4 & 13,8 & 29 & 100,0 & 0,4396 \\ \text { TOTAL }^{(2)} & 14 & 40,0 & 17 & 48,6 & 4 & 11,4 & 35 & 100,0 & \end{array}$

- Índice geral para metástase linfonodal

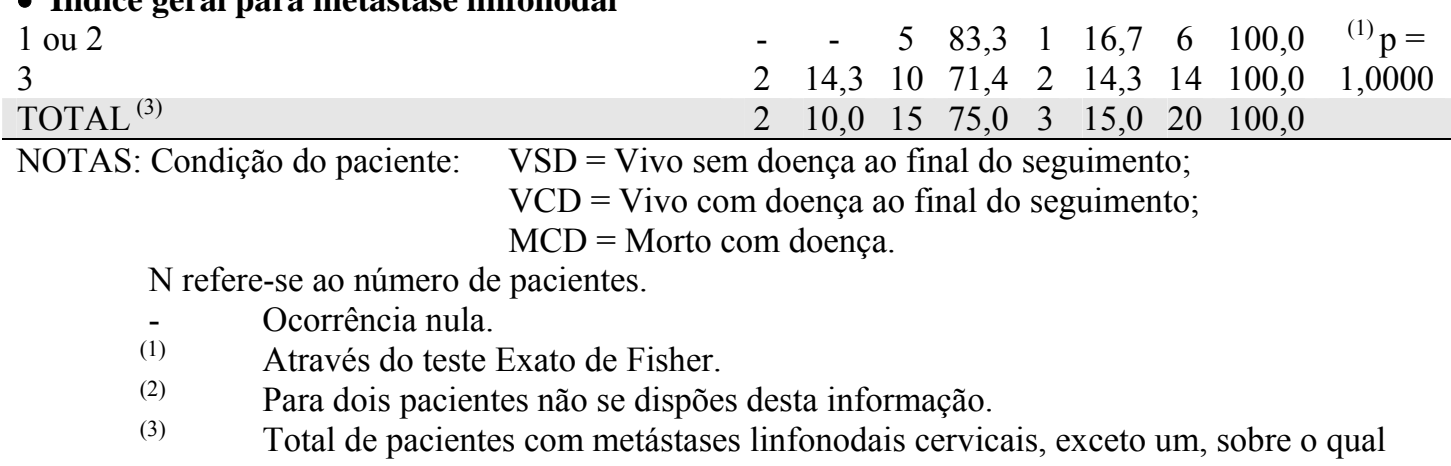

não se dispõe a informação. 
Tabela 31 - Avaliação de evolução inicial (cura ou persistência) segundo as variáveis relativas à imunocoloração para MT1-MMP: proporção de células marcadas em tumor primário, intensidade de marcação em tumor primário, proporção de células marcadas em metástase linfonodal, intensidade de marcação em metástase linfonodal, índice geral para tumor primário e índice geral para metástase linfonodal, segundo sistema de índices proposto na seção "Métodos" e após aglutinação dos casos "Índices 1 ” e " 2 "

\begin{tabular}{|c|c|c|c|c|c|c|c|}
\hline \multirow{3}{*}{$\begin{array}{l}\text { VARIÁVEL } \\
\text { MT1-MMP }\end{array}$} & \multicolumn{4}{|c|}{ EVOLUÇÃO } & \multirow{2}{*}{\multicolumn{2}{|c|}{ TOTAL }} & \multirow{3}{*}{$\begin{array}{c}\text { Valor } \\
\text { de } \\
p\end{array}$} \\
\hline & \multicolumn{2}{|c|}{ Cura } & \multicolumn{2}{|c|}{ Persistência } & & & \\
\hline & $\mathrm{N}$ & $\%$ & $\mathrm{~N}$ & $\%$ & $\mathrm{~N}$ & $\%$ & \\
\hline
\end{tabular}

- Proporção de células marcadas em tumor primário

$\begin{array}{lccccccc}1 \text { ou } 2 & 9 & 90,0 & 1 & 10,0 & 10 & 100,0 & { }^{(1)} \mathrm{p}= \\ 3 & 10 & 40,0 & 15 & 60,0 & 25 & 100,0 & 0,0098^{*} \\ \text { TOTAL }^{(2)} & 19 & 54,3 & 16 & 45,7 & 35 & 100,0 & \end{array}$

- Intensidade de marcação em tumor primário

1 ou 2

3

TOTAL $^{(2)}$

$\begin{array}{ccccccc}4 & 44,4 & 5 & 55,6 & 9 & 100,0 & { }^{(1)} \mathrm{p}= \\ 15 & 57,7 & 11 & 42,3 & 26 & 100,0 & 0,7003 \\ 19 & 54,3 & 16 & 45,7 & 35 & 100,0\end{array}$

- Proporção de células marcadas em metástase linfonodal

1 ou 2

3

TOTAL $^{(3)}$

$\begin{array}{ccccccc}1 & 16,7 & 5 & 83,3 & 6 & 100,0 & (1) \mathrm{p}= \\ 4 & 28,6 & 10 & 71,4 & 14 & 100,0 & 1,0000 \\ 5 & 25,0 & 15 & 75,0 & 20 & 100,0\end{array}$

- Intensidade de marcação em metástase linfonodal

$\begin{array}{lccccccc}1 \text { ou } 2 & 1 & 9,1 & 10 & 90,9 & 11 & 100,0 & { }^{(1)} \mathrm{p}= \\ 3 & 4 & 44,4 & 5 & 55,6 & 9 & 100,0 & 0,1273 \\ \text { TOTAL }^{(3)} & 5 & 25,0 & 15 & 75 & 20 & 100,0 & \end{array}$

- Índice geral para tumor primário

1 ou 2

3

TOTAL $^{(2)}$

$\begin{array}{ccccccc}6 & 100,0 & - & - & 6 & 100,0 & { }^{(1)} \mathrm{p}= \\ 13 & 44,8 & 16 & 55,2 & 29 & 100,0 & 0,0216^{*} \\ 19 & 54,3 & 16 & 45,7 & 35 & 100,0 & \end{array}$

- Índice geral para metástase linfonodal

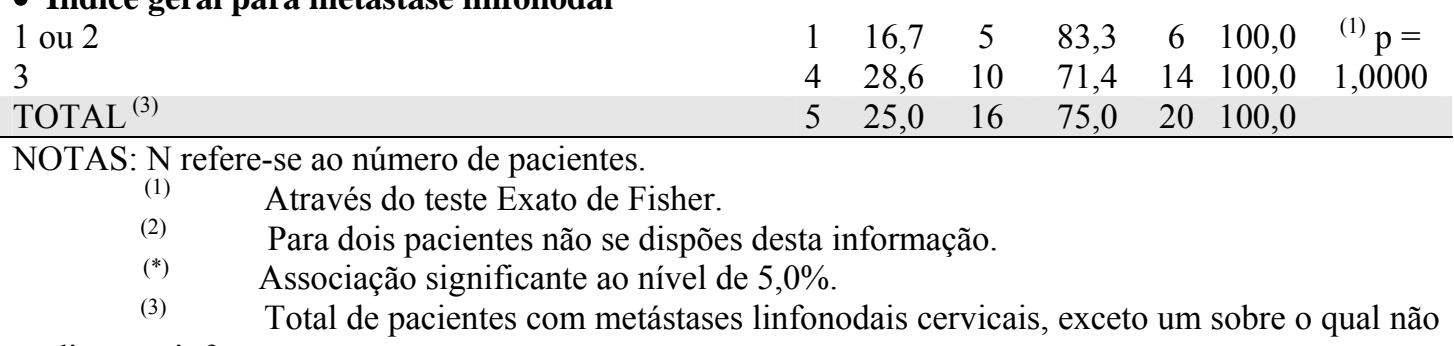
se dispõe a informação.

Ocorrência nula. 


\subsection{ANÁLISE ESTATÍSTICA DAS VARIÁVEIS RELACIONADAS À MARCAÇÃO TIMP-2}

Para análise estatística das relações entre imunocolorações para TIMP-2 e condições clínicas ao final dos seguimentos ou evoluções clínicas após o tratamento operatório inicial, os pacientes cujos "Índices" de marcação foram identificados como "1" ou "2" também foram agrupados em um único segmento de casos, para que fossem comparados com aqueles cujas lesões neoplásicas estudadas haviam sido classificadas como "Índice 3". Através das tabelas seguintes (32 e 33), observa-se que os métodos propostos para quantificação e qualificação das representações imuno-histoquímicas de TIMP-2 nos espécimes estudados proporcionaram valores sem significância estatística quanto às condições clínicas finais e evoluções iniciais, após o tratamento cirúrgico.

Em um único paciente observou-se divergência entre o "índice geral" para o tumor primário (“Índice Geral 3”) e sua metástase linfonodal cervical (“Índice Geral 2"). Encontrava-se vivo e com doença bioquímica ao final do seguimento. 
Tabela 32 - Avaliação de condição clínica final segundo as variáveis relativas à imunocoloração para TIMP-2: proporção de células marcadas em tumor primário, intensidade de marcação em tumor primário, proporção de células marcadas em metástase linfonodal, intensidade de marcação em metástase linfonodal, índice geral para tumor primário e índice geral para metástase linfonodal, segundo sistema de índices proposto na seção "Métodos" e após aglutinação dos casos "Índices 1" e " 2 "

\begin{tabular}{|c|c|c|c|c|c|c|c|c|}
\hline \multirow{3}{*}{$\begin{array}{c}\text { VARIÁVEL } \\
\text { TIMP-2 }\end{array}$} & \multicolumn{5}{|c|}{ CONDIÇÃO CLÍNICA } & \multirow{2}{*}{\multicolumn{2}{|c|}{ TOTAL }} & \multirow{3}{*}{$\begin{array}{c}\text { Valor } \\
\text { de } \\
\text { p }\end{array}$} \\
\hline & VSD & & & & CD & & & \\
\hline & $\%$ & $\mathrm{~N}$ & $\%$ & $\mathrm{~N}$ & $\%$ & $\mathrm{~N}$ & $\%$ & \\
\hline
\end{tabular}

- Proporção de células marcadas em tumor primário

$\begin{array}{lccccccccc}1 \text { ou } 2 & 1 & 33,3 & 2 & 66,7 & - & - & 3 & 100,0 & { }^{(1)} \mathrm{p}= \\ 3 & 13 & 38,7 & 15 & 48,4 & 4 & 12,9 & 31 & 100,0 & 1,0000 \\ \text { TOTAL }^{(2)} & 13 & 38,2 & 17 & 50,0 & 4 & 11,8 & 34 & 100,0 & \end{array}$

- Intensidade de marcação em tumor primário

$\begin{array}{lrrrrrrrrr}1 \text { ou } 2 & 6 & 42,9 & 7 & 50,0 & 1 & 7,1 & 14 & 100,0 & { }^{(1)} \mathrm{p}= \\ 3 & 7 & 35,0 & 10 & 50,0 & 3 & 15,0 & 20 & 100,0 & 0,8921 \\ \text { TOTAL }^{(2)} & 13 & 38,2 & 17 & 50,0 & 4 & 11,8 & 34 & 100,0 & \end{array}$

- Proporção de células marcadas em metástase linfonodal

$\begin{array}{llllllllll}1 \text { ou } 2 & - & - & 3 & 75,0 & 1 & 25,0 & 4 & 100,0 & \begin{array}{c}{ }^{(1)} \mathrm{p} \\ =\end{array} \\ 3 & 2 & 12,5 & 12 & 75,0 & 2 & 12,5 & 16 & 100,0 & 1,0000\end{array}$

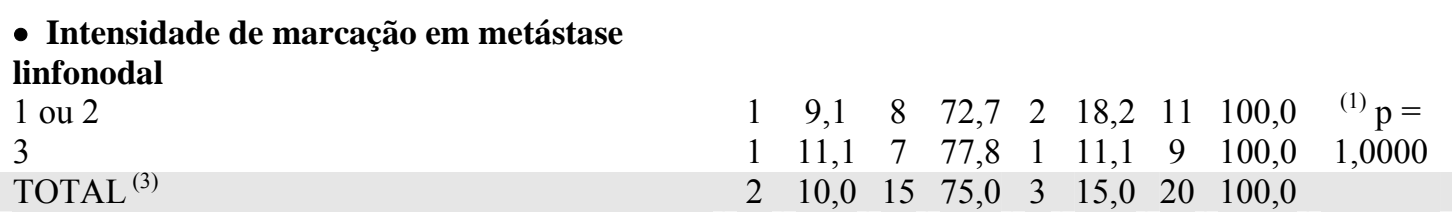
- Índice geral para tumor primário

$\begin{array}{lccccccccc}1 \text { ou } 2 & 2 & 40,0 & 2 & 40,0 & 1 & 20,0 & 5 & 100,0 & { }^{(1)} \mathrm{p}= \\ 3 & 11 & 37,9 & 15 & 51,7 & 3 & 10,3 & 29 & 100,0 & 0,8094 \\ \text { TOTAL }^{(2)} & 13 & 38,2 & 17 & 50,0 & 4 & 11,8 & 34 & 100,0 & \end{array}$

- Índice geral para metástase linfonodal

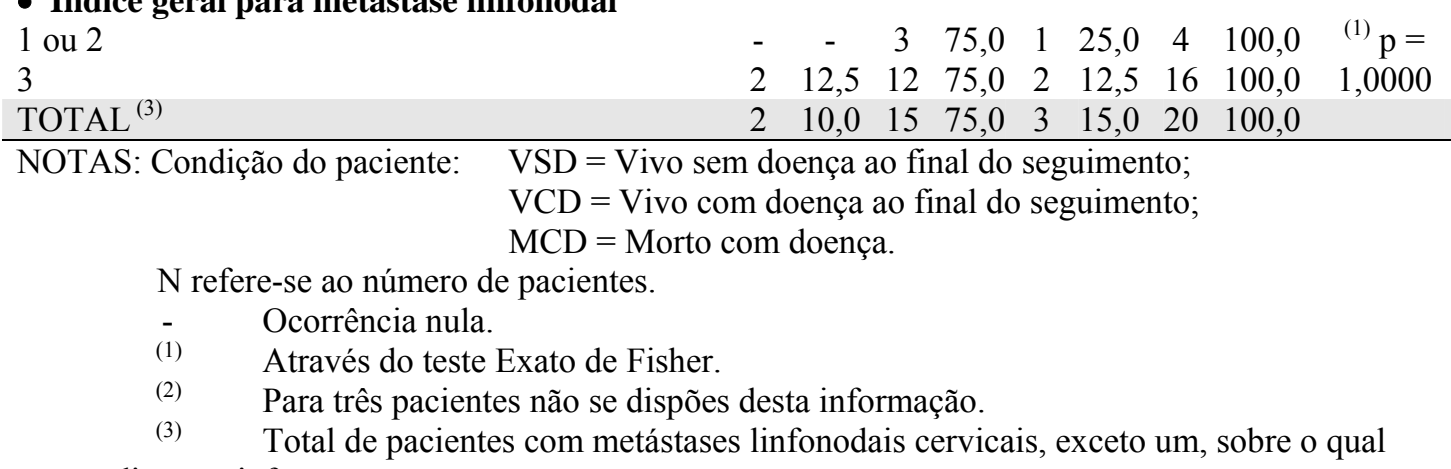

não se dispõe a informação. 
Tabela 33 - Avaliação de evolução inicial (cura ou persistência) segundo as variáveis relativas à imunocoloração para TIMP-2: proporção de células marcadas em tumor primário, intensidade de marcação em tumor primário, proporção de células marcadas em metástase linfonodal, intensidade de marcação em metástase linfonodal, índice geral para tumor primário e índice geral para metástase linfonodal, segundo sistema de índices proposto na seção "Métodos" e após aglutinação dos casos "Índices 1" e "2"

\begin{tabular}{|c|c|c|c|c|c|c|c|}
\hline \multirow{3}{*}{$\begin{array}{c}\text { VARIÁVEL } \\
\text { TIMP-2 }\end{array}$} & \multicolumn{4}{|c|}{ EVOLUÇÃO } & \multirow{2}{*}{\multicolumn{2}{|c|}{ TOTAL }} & \multirow{3}{*}{$\begin{array}{c}\text { Valor } \\
\text { de } \\
\text { P }\end{array}$} \\
\hline & \multicolumn{2}{|c|}{ Cura } & \multicolumn{2}{|c|}{ Persistência } & & & \\
\hline & $\mathrm{N}$ & $\%$ & $\mathrm{~N}$ & $\%$ & $\mathrm{~N}$ & $\%$ & \\
\hline \multicolumn{8}{|c|}{$\begin{array}{l}\text { - Proporção de células marcadas em tumor } \\
\text { primário }\end{array}$} \\
\hline 1 ou 2 & 2 & 66,7 & 1 & 33,3 & 3 & 100,0 & ${ }^{(1)} \mathrm{p}=$ \\
\hline 3 & 16 & 51,6 & 15 & 48,4 & 31 & 100,0 & 1,0000 \\
\hline TOTAL $^{(2)}$ & 18 & 52,9 & 16 & 47,1 & 34 & 100,0 & \\
\hline \multicolumn{8}{|c|}{ - Intensidade de coloração em tumor primário } \\
\hline 1 ou 2 & 8 & 57,1 & 6 & 42,9 & 14 & 100,0 & ${ }^{(1)} \mathrm{p}=$ \\
\hline 3 & 10 & 50,0 & 10 & 50,0 & 20 & 100,0 & 0,7385 \\
\hline TOTAL $^{(2)}$ & 18 & 52,9 & 16 & 47,1 & 34 & 100,0 & \\
\hline
\end{tabular}

- Proporção de células marcadas em metástase linfonodal

$\begin{array}{lccccccc}1 \text { ou } 2 & 1 & 25,0 & 3 & 75,0 & 4 & 100,0 & { }^{(1)} \mathrm{p}= \\ 3 & 4 & 25,0 & 12 & 75,0 & 16 & 100,0 & 1,0000 \\ \text { TOTAL }^{(3)} & 5 & 25,0 & 15 & 75,0 & 20 & 100,0 & \end{array}$

$\begin{array}{lccccccc}\text { • Intensidade de marcação em metástase linfonodal } & & & & & & & \\ 1 \text { ou } 2 & 4 & 36,4 & 7 & 63,6 & 11 & 100,0 & \\ 3 & 1 & 11,1 & 8 & 88,9 & 9 & 100,0 & 0,3189 \\ 3 \text { TOTAL }^{(3)} & 5 & 25,0 & 15 & 75,0 & 20 & 100,0 & \end{array}$

- Índice geral para tumor primário

$\begin{array}{lccccccc}1 \text { ou } 2 & 3 & 60,0 & 2 & 40,0 & 5 & 100,0 & { }^{(1)} \mathrm{p}= \\ 3 & 15 & 51,7 & 14 & 48,3 & 29 & 100,0 & 1,0000 \\ \text { TOTAL }^{(2)} & 18 & 52,9 & 16 & 47,1 & 34 & 100,0 & \end{array}$

- Índice geral para metástase linfonodal

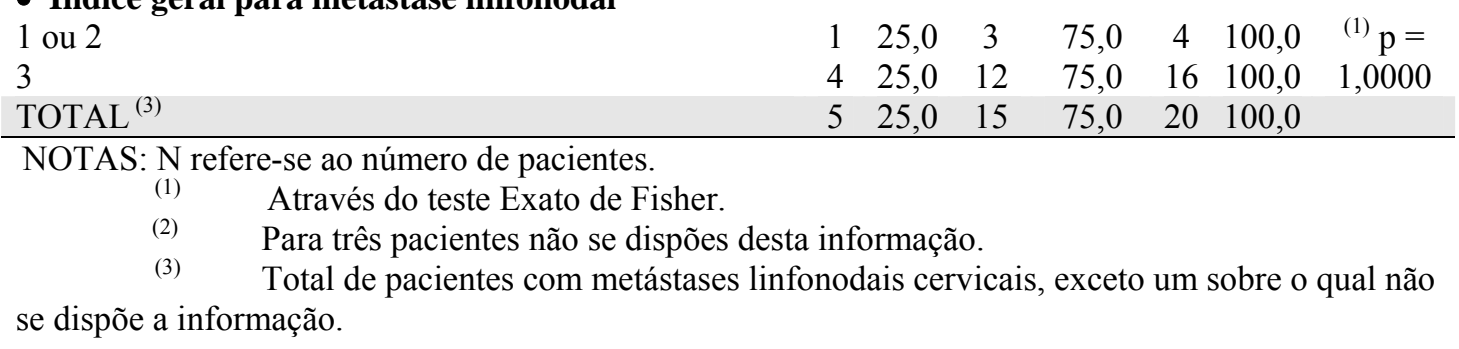




\subsection{ANÁLISE ESTATÍSTICA DAS VARIÁVEIS RELACIONADAS À RAZÃO DE MARCAÇÃO MMP-2/TIMP-2}

Partindo-se do pressuposto que o TIMP-2 deve comportar-se como supressor da atividade da MMP-2, pela própria definição daquela classe de enzimas, os “índices gerais” para o tumor primário, relativos às expressões imuno-histoquímicas de MMP-2, foram divididos pelos “índices gerais” para o tumor primário, relativos às expressões imuno-histoquímicas de TIMP-2, para cada caso. Dois resultados possíveis foram obtidos: “1,0”, para aqueles pacientes cujos espécimes foram pontuados com índices semelhantes para os dois marcadores e " 0,7 ”, quando o “Índice" relativo à expressão de MMP-2 foi "2" e o "Índice" relativo à expressão de TIMP-2 foi classificado como "3”. A correlação não pode ser realizada para quatro espécimes (casos 5, 9, 23 e 37), por indisponibilidade de dados. Tal índice foi denominado "índice relativo". Treze pacientes foram classificados como "Índice Relativo 0,7” e, 20 casos, como “Índice Relativo 1,0”.

Os "índices relativos" foram correlacionados com aspectos clinicopatológicos cujas análises estatísticas, demonstradas em seção anterior, evidenciaram associação com o comportamento clínico dos pacientes (Tabela 34). “Índice Relativo 0,7” foi associado a situações relacionadas a melhores prognósticos, enquanto os pacientes pontuados como "Índice Relativo 1,0" apresentaram maior freqüência de situações de risco para o comprometimento prognóstico. As variáveis cujas correlações com os "índices relativos" apresentaram significância estatística foram: presença de nódulos tireóideos e/ou adenomegalia cervical metastática palpáveis ao diagnóstico de CMT 
(exame físico cervical positivo) $(\mathrm{p}=0,0248)$, presença de metástases linfonodais cervicais $(p=0,0002)$ e condição clínica final (vivo sem doença, vivo com doença ou morto pela doença) $(p=0,0149)$. Presença de sintomas sistêmicos ao diagnóstico de CMT, extensão da neoplasia para além do tecido tireóideo, invasão neoplásica vascular, Estádio patológico IV, persistência neoplásica após procedimento cirúrgico inicial, recidiva neoplásica e evolução com evidências clínicas ou imagenológicas de doença cervical e/ou metastática a distância foram mais freqüentes entre os pacientes “Índice Relativo 1,0”, embora não se tenha observado significância estatística nestas observações (Tabela 34). Para facilitação da análise, pacientes estadiados como I, II e III foram alocados em um grupo único, separado dos pacientes Estádio IV.

Tabela 34 - Avaliação das variáveis: exame físico cervical e sintomas sistêmicos ao diagnóstico de CMT, extensão neoplásica para tecidos adjacentes, invasão neoplásica vascular, metástases linfonodais cervicais, estádios patológicos, evolução clínica após tratamento cirúrgico inicial, recidiva neoplásica, evidências de doença cervical e/ou a distância e condições clínicas finais, segundo valor de "índice relativo" MMP2/TIMP-2

\begin{tabular}{|c|c|c|c|c|c|c|c|}
\hline \multirow{3}{*}{ VARIÁVEL } & \multicolumn{4}{|c|}{$\begin{array}{c}\text { ÍNDICE } \\
\text { RELATIVO }\end{array}$} & & & \multirow{3}{*}{$\begin{array}{c}\text { Valor de } \\
\mathrm{p}\end{array}$} \\
\hline & \multicolumn{2}{|c|}{0,7} & \multicolumn{2}{|c|}{1,0} & \multicolumn{2}{|c|}{ TOTAL } & \\
\hline & $\mathrm{N}$ & $\%$ & $\mathrm{~N}$ & $\%$ & $\mathrm{~N}$ & $\%$ & \\
\hline \multicolumn{8}{|l|}{ - Exame físico cervical } \\
\hline Positivo & 8 & 61,5 & 19 & 95,0 & 27 & 81,8 & ${ }^{(1)} \mathrm{p}=$ \\
\hline Negativo & 5 & 38,5 & 1 & 5,0 & 6 & 18,2 & $0,0248 *$ \\
\hline TOTAL & 13 & 100,0 & 20 & 100,0 & 33 & 100,0 & \\
\hline
\end{tabular}

- Sintomas sistêmicos

$\begin{array}{lccccccc}\text { Sim } & 1 & 7,7 & 5 & 25,0 & 6 & 81,8 & { }^{(1)} \mathrm{p}= \\ \text { Não } & 12 & 92,3 & 15 & 75,0 & 27 & 18,2 & 0,3644 \\ \text { TOTAL } & 13 & 100,0 & 20 & 100,0 & 33 & 100,0 & \end{array}$

- Extensão neoplásica para tecidos adjacentes

$\begin{array}{lcccccccc}\text { Sim } & 1 & 7,7 & 3 & 15,0 & 4 & 12,1 & { }^{(1)} \mathrm{p}= \\ \text { Não } & 12 & 92,3 & 17 & 85,0 & 29 & 87,9 & 1,0000 \\ \text { TOTAL } & 13 & 100,0 & 20 & 100,0 & 33 & 100,0 & \\ & & & & & & & \text { continua }\end{array}$


Conclusão - Tabela 34

\begin{tabular}{|c|c|c|c|c|c|c|c|}
\hline \multirow{3}{*}{ VARIÁVEL } & \multicolumn{4}{|c|}{$\begin{array}{c}\text { ÍNDICE } \\
\text { RELATIVO }\end{array}$} & \multicolumn{2}{|c|}{ TOTAL } & \multirow{3}{*}{$\begin{array}{c}\text { Valor de } \\
\mathrm{p}\end{array}$} \\
\hline & \multicolumn{2}{|r|}{0,7} & \multicolumn{2}{|c|}{1,0} & \multirow{2}{*}{$\begin{array}{c}0,7 \\
\% \\
\end{array}$} & \multirow{2}{*}{$\begin{array}{c}1,0 \\
\mathrm{~N} \\
\end{array}$} & \\
\hline & $\mathrm{N}$ & $\%$ & $\mathrm{~N}$ & $\mathrm{~N}$ & & & \\
\hline \multicolumn{8}{|l|}{ - Invasão vascular } \\
\hline $\operatorname{Sim}$ & 2 & 15,4 & 5 & 25,0 & 7 & 21,2 & ${ }^{(1)} \mathrm{p}=$ \\
\hline Não & 11 & 84,6 & 15 & 75,0 & 26 & 78,8 & 0,6756 \\
\hline TOTAL $^{(2)}$ & 13 & 100,0 & 20 & 100,0 & 33 & 100,0 & \\
\hline \multicolumn{8}{|l|}{ - Metásteses linofonodais cervicais } \\
\hline $\operatorname{Sim}$ & - & - & 13 & 65,0 & 13 & 39,4 & ${ }^{(1)} \mathrm{p}=$ \\
\hline Não & 13 & 100,0 & 7 & 35,0 & 20 & 60,6 & $0,0002 *$ \\
\hline TOTAL & 13 & 100,0 & 20 & 100,0 & 33 & 100,0 & \\
\hline
\end{tabular}

\section{- Estádios}

$\begin{array}{lccccccc}\text { IV } & 5 & 38,5 & 11 & 55,0 & 13 & 39,4 & { }^{(1)} \mathrm{p}= \\ \text { I a III } & 8 & 61,5 & 7 & 35,0 & 15 & 45,5 & 0,2852 \\ \text { TOTAL } & 13 & 100,0 & 20 & 100,0 & 33 & 100,0 & \end{array}$

\section{- Evolução inicial}

Cura

Persistência

$9 \quad 69,2 \quad 9 \quad 45,0 \quad 18 \quad 54,5 \quad{ }^{(3)} \mathrm{p}=$

TOTAL

$\begin{array}{lllllll}4 & 30,8 & 11 & 55,0 & 15 & 45,5 & 0,1720\end{array}$

$13 \quad 100,0 \quad 20 \quad 100,0 \quad 33 \quad 100,0$

\section{- Recidiva}

$\begin{array}{lccccccc}\text { Sim } & - & - & 5 & 25,0 & 5 & 15,2 & { }^{(1)} \mathrm{p}= \\ \text { Não } & 13 & 100 & 15 & 75,0 & 28 & 84,8 & 0,1310 \\ \text { TOTAL } & 13 & 100,0 & 20 & 100,0 & 33 & 100,0 & \end{array}$

- Evidências de doença cervical e/ou metastática a distância

$\begin{array}{lrrrrrrr}\text { Sim } & 2 & 15,4 & 10 & 50,0 & 12 & 36,4 & { }^{(1)} \mathrm{p}= \\ \text { Não }{ }^{(4)} & 11 & 84,6 & 10 & 50,0 & 31 & 63,6 & 0,0672 \\ \text { TOTAL } & 13 & 100,0 & 20 & 100,0 & 33 & 100,0 & \end{array}$

\section{- Condição clínica final}

Vivo sem doença

Vivo com doença

$9 \quad 69,2 \quad 4 \quad 20,0 \quad 13 \quad 39,3 \quad{ }^{(1)} \mathrm{p}=$

Morto pela doença

$3 \quad 23,1 \quad 13 \quad 65,0 \quad 16 \quad 48,5 \quad 0,0149 *$

TOTAL

$\begin{array}{llllll}1 & 7,7 & 3 & 15,0 & 4 & 12,1\end{array}$

NOTAS: N refere-se ao número de pacientes.

(1) Através do teste Exato de Fisher.

(*) Associação significante ao nível de 5,0\%.

(2) Dados desconhecidos (não constavam nos laudos anatomopatológicos originais) foram considerados como sendo negativos.

- $\quad$ Ocorrência nula.

(3) Através do teste Qui-quadrado de Pearson.

(4) Incluem os pacientes curados e com doença bioquímica. 


\subsection{ANÁLISE DE TEMPO LIVRE DE DOENÇA}

Na Tabela 35 estão demonstradas as estimativas de probabilidade de tempo livre de doença para o grupo, através do método de Kaplan-Meier, considerando-se como evento persistência ou recidiva do carcinoma medular. Observou-se que, a partir de 71 meses de seguimento, a probabilidade de o paciente encontrar-se livre de doença era de 0,3067 . A partir deste ponto de seguimento, apenas três pacientes sem evidências bioquímicas, clínicas ou imagenológicas de CMT ainda encontravam-se sob acompanhamento clínico e foram considerados os pacientes de risco para o evento em questão. Neste mesmo momento, 22 pacientes já haviam demonstrado evidências de persistência ou recidiva neoplásicas. No Gráfico 2 (Figura 12), os mesmos dados estão expostos sob curva de Kaplan-Meier. Momentos em que seguimentos clínicos foram interrompidos foram assinalados como "censurados" na representação gráfica.

Tabela 35 - Estimativa de probabilidade de tempo livre da doença segundo método de Kaplan-Meier (evento: persistência ou recidiva)

\begin{tabular}{|c|c|c|c|c|}
\hline $\begin{array}{l}\text { NÚMERO DE } \\
\text { PACIENTES }\end{array}$ & TEMPO (meses) & $\begin{array}{l}\text { P (sobrevivência } \\
\text { livre de doença) }\end{array}$ & $\begin{array}{c}\text { DOENÇA } \\
\text { ACUMULADA }\end{array}$ & $\begin{array}{c}\text { NÚMERO DE } \\
\text { PACIENTES } \\
\text { EM RISCO } \\
\end{array}$ \\
\hline \multirow{6}{*}{37} & 0 a 5 & 0,5405 & 17 & 20 \\
\hline & 6 a 11 & 0,5121 & 18 & 19 \\
\hline & 12 a 13 & 0,4820 & 19 & 17 \\
\hline & 14 a 27 & 0,4498 & 20 & 14 \\
\hline & 28 a 70 & 0,4089 & 21 & 10 \\
\hline & 71 a 189 & 0,3067 & 22 & 3 \\
\hline
\end{tabular}

NOTAS: P: probabilidade

Valor mediano: 12 meses. 


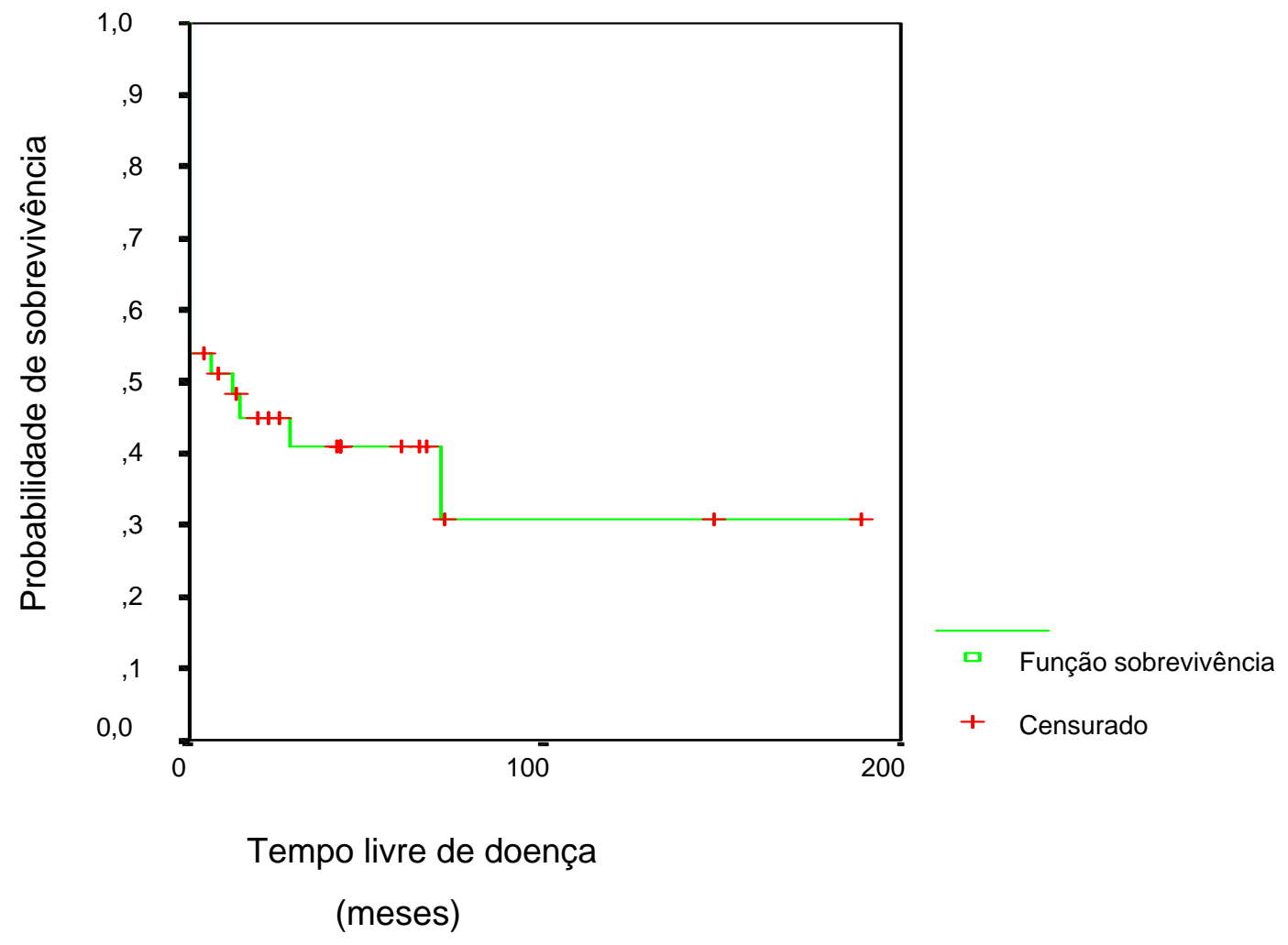

Figura 12. Gráfico 2 - Curva de Kapplan-Meier para sobrevida livre de doença

\subsection{ANÁLISE DE SOBREVIDA}

Na Tabela 36 estão demonstradas as estimativas de probabilidade de sobrevida para o grupo através do método de Kaplan-Meier, considerando-se como evento o óbito. Observou-se que, a partir de 88 meses de seguimento, a probabilidade de o paciente encontrar-se vivo era de 0,8382 , quatro pacientes da amostra já haviam falecido e 13 permaneciam sob seguimento clínico. No Gráfico 3 (Figura 13), os 
mesmos dados estão expostos sob curva de Kaplan-Meier e os dados "censurados" referem-se aos pacientes cujos seguimentos clínicos foram interrompidos.

Tabela 39 - Estimativa de probabilidade de sobrevida pelo método de KaplanMeier (evento: óbito)

\begin{tabular}{c|c|c|c|c}
\hline $\begin{array}{c}\text { NÚMERO DE } \\
\text { PACIENTES }\end{array}$ & TEMPO (meses) & P (sobrevida) & $\begin{array}{c}\text { ÓBITO } \\
\text { ACUMULADO }\end{array}$ & $\begin{array}{c}\text { PACIENTES } \\
\text { EM RISCO }\end{array}$ \\
\hline \multicolumn{5}{c}{} \\
& 4 a 13 & 1,0000 & & 37 \\
37 & 14 a 15 & 0,9697 & 1 & 33 \\
& 16 a 18 & 0,9394 & 2 & 32 \\
& 19 a 87 & 0,9081 & 3 & 13 \\
\hline
\end{tabular}

NOTAS: P: probabilidade faleceram.

Valor mediano: não foi possível determinar porque menos da metade dos pacientes

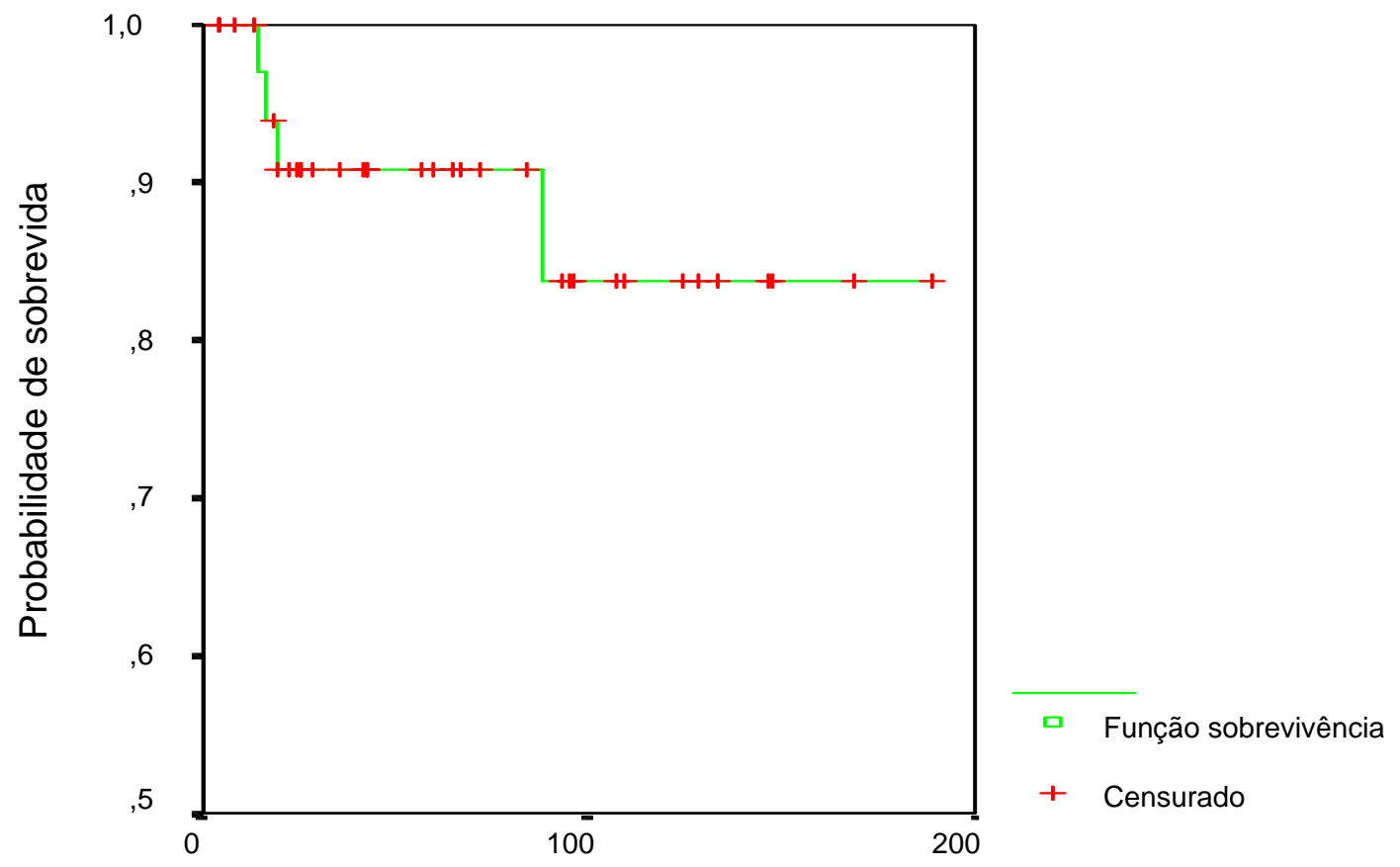

Tempo de sobrevida (meses)

Figura 13. Gráfico 3 - Curva de Kapplan-Meier para sobrevida 
6 DISCUSSÃO 


\section{DISCUSSÃO}

\subsection{VARIÁVEIS CLINICOPATOLÓGICAS}

O carcinoma medular da glândula tireóide caracteriza-se por comportamento biológico pouco previsível e bastante variável, além de pouco responsivo a armas terapêuticas não-cirúrgicas, embora condutas preconizadas nem sempre promovam cura definitiva. $\mathrm{O}$ desenvolvimento de metástases, principalmente em linfonodos cervicais, é precoce e o tratamento cirúrgico, também precoce e extenso, justifica-se como único método factível para cura e com considerável impacto prognóstico.

Ao se considerar a calcitonina sérica como marcador específico e sensível para o CMT, essa é utilizada para diagnósticos de recidiva e persistência neoplásicas, uma vez que dosagens elevadas devem indicar presença de focos de células tumorais. É comum a observação de pacientes tratados que se mantém com níveis séricos elevados de CT por longos períodos de tempo, sem que surjam evidências clínicas ou imagenológicas de doença residual ou recidivante ou que a mesma progrida, talvez até por insensibilidade dos métodos de imagem disponíveis. Já foi relatada excelente sobrevida a longo prazo em pacientes com calcitonemias elevadas pós-operatórias, sem que doença residual ou recidivante, primária ou metastática, pudesse ser

identificada. ${ }^{90}$ Observar, porém, que até níveis indetectáveis de calcitonina sérica sob estímulo não excluem o risco de recidiva ou doença presente, como já foi 
observado por alguns autores ${ }^{15}$ e creditado a tendências à indiferenciação da neoplasia. Para o presente trabalho, porém, utilizou-se o exame como método definitivo de determinação de cura, ou não, como orienta o Consenso para Diagnóstico e Terapia das Neoplasias Endócrinas Múltiplas de $2001 .{ }^{43}$ Tal análise, por sua vez, foi prejudicada por longos períodos em que o exame não esteve disponível no Hospital das Clínicas, como também pela não aderência dos pacientes aos seguimentos ambulatoriais e controles séricos laboratoriais. O mesmo se pode observar em relação ao emprego de dosagens séricas de CEA como marcador tumoral complementar. Diferentes referências laboratoriais, empregadas ao longo dos anos, fizeram com que as observações deste trabalho fossem baseadas em valores relativos dos marcadores citados, a partir dos máximos valores de referência. A confirmação de cura, por sua vez, deve ser feita com o emprego de dosagens séricas de CT sob estímulo. Segundo revisão dos prontuários médicos consultados, o exame só foi disponibilizado para seis pacientes do grupo (casos 6, 27, 30, 34, 35 e 36), para confirmação de cura bioquímica.

Não se pode acreditar que a amostra estudada seja representação populacional de afetados pelo carcinoma medular da tireóide em nosso meio, uma vez que só foram incluídos no estudo aqueles pacientes cujos prontuários médicos ofereciam informações clinicopatológicas relevantes e cujas peças operatórias continham material adequado para estudo, com sacrifício de mais da metade da amostra inicial. Foram excluídos, por exemplo, portadores de carcinomas medulares familiares isolados e apenas um caso de CMT NEM2B foi incluído na linha de pesquisa. No entanto, mesmo entre os pacientes considerados elegíveis, informações a respeito de todos os itens analisados nem sempre foram obtidas. Dos 37 pacientes incluídos, 
nove $(24,3 \%)$ abandonaram seus seguimentos clínicos, número não inesperado, uma vez que os pacientes provieram, em sua maioria, de instituição pública de saúde e muitos eram domiciliados em outras regiões do país.

Os seguimentos clínicos variaram de quatro a 189 meses a partir do tratamento cirúrgico inicial, com média de 65,62 meses, ou cinco anos e cinco meses, e mediana de 57 meses, ou quatro anos e nove meses. Ao se considerar que o CMT permite longos períodos de sobrevida, apesar de neoplasia bioquímica ou mesmo clínica, antes que a doença progrida, o tempo médio de seguimento dos pacientes estudados pode ser considerado como pouco representativo. No entanto, as dificuldades para acesso a pacientes mais antigos e a seus respectivos materiais operatórios foram maiores e por vezes impeditivas. Nos últimos anos, os portadores de CMT foram submetidos a tratamentos e seguimentos clínicos mais uniformes, garantindo maior homogeneidade entre os pacientes ditos mais recentes, embora ainda seja notória a variabilidade de idades ao diagnóstico, formas de doença e comportamentos clínicos.

Trabalhos retrospectivos que buscaram identificar fatores prognósticos relacionados ao CMT contaram com períodos médios distintos de seguimento clínico: um mês a 28,8 anos, mediana de 6,1 anos (Saad et al. ${ }^{1}$ ); média de 4,9 anos e mediana de 3,2 anos (Modigliani et al. ${ }^{9}$ ); média de 8,6 anos e mediana de cinco anos (Kebebew et al. ${ }^{10}$ ); dois a 31 anos, mediana de nove anos (Hyer et al. ${ }^{11}$ ); três a 40 meses, média de 27 meses (Kaserer et al. ${ }^{12}$ ); medianas de 88 e 69 meses (Schilling et al. ${ }^{51}$ ); cinco a 78 meses e mediana de 38,7 meses (Weber et al. ${ }^{94}$ ); zero a 15 anos, mediana de dois anos (Szinnai et al. ${ }^{48}$ ); três a 161 meses, média de 55,8 meses (Brauckhoff et al. ${ }^{64}$ ); entre outros. Deve-se considerar que, quando as perspectivas para sobrevida são razoáveis, torna-se mais difícil a identificação de seus fatores 
prognósticos, principalmente se as amostras para estudo são pequenas. ${ }^{6}$ No presente trabalho, quando as análises estatísticas não proporcionaram resultados confiáveis devido ao pequeno número de eventos correlacionados, os dados foram suprimidos. Da mesma forma, a análise estatística multivariada dos aspectos clinicopatológicos analisados não pode ser realizada. Foi aplicada regressão logística através de programa computadorizado apropriado, sem sucesso.

Dos 37 pacientes estudados, $16(43,2 \%)$ tinham até 30 anos de idade e 23 (62,1\%) até 40 anos ao diagnóstico de CMT. Média etária foi calculada em 33,24 anos e mediana em 33 anos. Entre os portadores de CMT-E, média etária foi calculada em 42 anos e, em 21,75 anos, para os portadores de CMT-F. Contribuiu para esta significativa diferença $(\mathrm{p}<0,0001)$ a prática do rastreamento, cuja média etária dos pacientes assim diagnosticados foi calculada em 20,61 anos, observandose que oito, de 13 pacientes, contavam com no máximo 20 anos de idade e, apenas dois indivíduos, mais que 30 anos (32 e 36 anos) ao diagnóstico. Três casos familiares foram considerados "index" e suas idades ao diagnóstico foram 10, 33 e 37 anos, com média de 26,7 anos.

Em outros estudos desenvolvidos em nosso meio, inclusive com sobreposição de casos, foram observadas médias etárias de 36,17 anos ao diagnóstico (43,9 anos para esporádicos e 26,09 anos para casos familiares) ${ }^{8}$ e 33,2 anos $(46,4$ anos para esporádicos e 23 anos para casos familiares). ${ }^{69}$ No presente trabalho, médias etárias ao diagnóstico foram menores que as observadas na literatura. Estas já foram calculadas em 50,5 anos em estudo de $1996,{ }^{7}$ conduzido com pacientes atendidos em período prévio à introdução de programas de rastreamento; em 43,4 anos, sendo 52,3 anos para casos esporádicos e 29 anos para familiares; ${ }^{9}$ em 44 anos; ${ }^{11}$ em 38 
anos, sendo 47,3 anos para portadores de CMT-E e 29,1 anos para portadores de CMT-F; ${ }^{10}$ em 58 anos para casos esporádicos e 32 para familiares; ${ }^{12}$ em 38,7 anos, sendo 43,7 para pacientes esporádicos e 34,3 para familiares; ${ }^{94} \mathrm{em} 49,7$ anos; ${ }^{6} \mathrm{em}$ 42 anos; ${ }^{15}$ em 47,6 anos para casos esporádicos, 35,6 para vinculados à NEM2A, 34,6 para casos familiares isolados e 30,5 para vinculados à NEM2B; ${ }^{17}$ entre outros exemplos. Faz-se pertinente, porém, considerar diferenças de proporções entre as formas familiares e esporádica da doença e os períodos de desenvolvimento dos estudos (prévios ou não à introdução de programas de rastreamento), além das dimensões das amostras e critérios de inclusão dos pacientes.

Não foram observadas correlações estatísticas entre faixas etárias ao diagnóstico (A a E, especificadas na seção "Métodos") e evoluções clínicas (cura e persistência ou recidiva) $(\mathrm{p}=0,1255$, Tabela 27$)$, e condições clínicas finais (VSD, VCD e MCD) $(\mathrm{p}=0,1498$, Tabela 19) ou entre médias etárias para cada grupo quanto às mesmas condições clínicas finais $(\mathrm{p}=0,5844)$. Ressalta-se que o pequeno número de casos em cada faixa etária estipulada fez com que os resultados obtidos fossem utilizados com reserva, embora observações semelhantes, talvez pela heterogeneidade da amostra, tivessem sido feitas quando os pacientes foram alocados sob faixas etárias mais amplas. Observou-se que os 10 pacientes cujos diagnósticos haviam sido realizados quando os mesmos contavam com até 20 anos de idade encontravam-se vivos ao final dos seguimentos, embora quatro estivessem doentes, perfazendo $60 \%$ de vivos sem doença ao final dos seguimentos, enquanto que $50 \%$ daqueles com 51 anos ou mais ao diagnóstico encontravam-se em situação semelhante. Entre os pacientes que faleceram, dois tinham entre 21 e 30 anos aos diagnósticos (33,3\% de grupo de seis pacientes), um contava com idade entre 41 e 50 
anos (10\% de grupo de 10 pacientes) e um com 65 anos (25\% de grupo de quatro pacientes com 51 anos ou mais). Nenhum dos seis indivíduos com idades entre $21 \mathrm{e}$ 30 anos ao diagnóstico curou-se. Entre os 23 pacientes com até 40 anos de idade ao diagnóstico, $10(43,5 \%)$ encontravam-se vivos e sem doença ao final dos seguimentos, proporção não muito maior à observada entre aqueles com 41 ou mais anos de idade ao diagnóstico de CMT (35,7\%) (Tabela 19).

Já se observou ${ }^{1,77}$ diferença significativa na sobrevida geral entre pacientes com menos de 40 anos e com 40 ou mais anos de idade, assim também como maior risco de óbito pela doença entre indivíduos com mais de 60 anos de idade ao diagnóstico. ${ }^{95}$ Gilliland et al. ${ }^{7}$ associaram decréscimo de sobrevida ao aumento de idade ao diagnóstico de CMT, em estudo com mais de 500 portadores da neoplasia. Outros estudos 6, 9-11,48, 159 também correlacionaram idade e prognóstico, com prejuízo para faixas etárias progressivamente mais avançadas. A esses se incluem, inclusive, dois trabalhados ${ }^{8,69}$ também desenvolvidos no Hospital das Clínicas da Faculdade de Medicina da USP e com pacientes comuns aos três estudos. Brauckhoff et al., ${ }^{64}$ porém, ao estudarem portadores de CMT NEM2B, observaram que, quando não curados, ocorreu significativa redução nas taxas de sobrevida em pacientes com 12 ou menos anos de idade ao diagnóstico, quando comparados com aqueles cujas idades eram superiores aos 12 anos ao diagnóstico, sugerindo presença de possíveis processos patológicos adicionais no primeiro grupo.

No presente estudo, observou-se acometimento de 1,85 mulheres para cada homem afetado (Tabela 4). Tendência a maior acometimento de indivíduos do sexo feminino, mesmo que discreta, também foi observada na grande maioria dos 
trabalhos consultados e que consideraram essa variável em suas análises. 1,6$12,15,69,88,159$

Não se obteve significância estatística ao se comparar gêneros e evoluções clínicas (Tabelas 19 e 27). Entretanto, 61,5\% dos homens tratados (oito de 13 pacientes) encontravam-se vivos e sem doença ao final dos seguimentos, contra 29,2\% das mulheres (sete de 24 pacientes), em proporção calculada em 1,22 homens curados para cada mulher em situação clínica semelhante (Tabela 14). As proporções entre os gêneros para recidiva (4:1) e persistência neoplásicas $(3,25: 1)$, também favoreceram os pacientes do sexo masculino (Tabela 13). Talvez sejam observações decorrentes da menor proporção de pacientes masculinos com metástases cervicais (38,5\%, contra $66,7 \%$ entre as mulheres), como também menor proporção de homens Estádio IV (38,5\%, contra 54,2\% entre as mulheres) à admissão. Em estudos consultados, porém, pacientes do sexo feminino apresentaram maiores taxas de sobrevida, 1,6-11, 159 inclusive quando comparados com homens afetados por neoplasias de estádios semelhantes, ${ }^{1}$ e menor risco de progressão da doença. ${ }^{95}$ Ainda não se conseguiu explicar o que levaria à diferença prognóstica quanto ao gênero. Ellenhorn et al. ${ }^{77}$ também não observaram influência do gênero nas evoluções clínicas.

A clássica relação de cerca de $75 \%$ de casos esporádicos para $25 \%$ de casos familiares tende a modificar-se. Contribuem para o processo a introdução do diagnóstico genético, que deve ser empregado mesmo nos pacientes em quem não existam suspeitas clínicas de doença familiar, além da popularização de programas de rastreamento, com busca ativa de acometidos entre familiares diretos de casos 
“index”. Grandes famílias de acometidos por mutações no RET também contribuem para o aumento da proporção de casos familiares.

Foram estudados 56,8\% de casos esporádicos, 40,5\% de CMT NEM2A, apenas um caso de CMT NEM2B (2,7\%) e nenhum acometido pela forma isolada do carcinoma medular familiar (Tabela 8). Quinze casos foram diagnosticados nos seis anos que antecederam o término da pesquisa (fevereiro de 2005), quatro casos entre seis e oito anos, três casos entre oito e 10 anos e 15 casos foram diagnosticados em momento que antecedeu em mais de 10 anos o término do estudo. De 13 pacientes diagnosticados por rastreamento, 12 tiveram seus diagnósticos realizados nos últimos seis anos.

Kameyama e Takami ${ }^{17}$ observaram 634 pacientes tratados até 1996 e 271 tratados até 2002, sem sobreposição de casos. Entre os dois períodos, notou-se redução da proporção de casos esporádicos em relação aos familiares, redução, porém, de apenas 1,4\%. Foi observado, no segundo grupo, menor média etária ao diagnóstico, como também importante participação do diagnóstico genético, em detrimento dos diagnósticos de casos familiares através da presença de tumores cervicais, dosagens séricas elevadas de CT ou sintomas sistêmicos.

Não foi comprovada participação da forma clínica de CMT na evolução ou condição clínica final (Tabelas 23 e 27). Entre os casos esporádicos, 38,1\% (oito casos) obtiveram cura, observada em $43,7 \%$ (sete pacientes) dos casos familiares, e 14,3\% faleceram (três casos), contra 6,3\% (um caso) entre os pacientes familiares, diferenças sem significância estatística $(p=0,8025)$. Sessenta e dois por cento (13 casos) dos pacientes esporádicos apresentaram persistências ou recidivas de suas neoplasias, enquanto $56,3 \%$ dos casos familiares (nove pacientes) assim o fizeram. 
Não houve diferença significativa entre os dois grupos, quanto às evoluções ( $p=$ 0,7285), com risco relativo de persistências ou recidivas apenas 1,10 vezes maior para os pacientes esporádicos, em relação aos familiares. Observou-se também, como citado anteriormente, que a diferença entre médias etárias ao diagnóstico foi estatisticamente significativa entre os dois grupos, mas sem influência prognóstica. As proporções de afetados por metástases linfonodais cervicais e pacientes classificados como Estádio IV foram semelhantes entre os grupos (Tabela 12). Já, títulos médios de CT basal ao diagnóstico foram muito distintos entre pacientes esporádicos e familiares, porém sem diferença estatística também $(\mathrm{p}=0,1446)$, uma vez que a variabilidade de valores foi imensa, com desvios padrões calculados em valores bastante superiores aos das médias.

Estudos ${ }^{1,9,10}$ são enfáticos quanto às diferenças prognósticas relativas às formas clínicas do carcinoma medular, favorecendo formas vinculadas à NEM2A, incluindo trabalho ${ }^{69}$ também desenvolvido no Hospital das Clínicas da Faculdade de Medicina da USP e com pacientes comuns ao nosso estudo. Já foram observadas maiores taxas de sobrevida entre pacientes portadores de carcinomas medulares vinculados à NEM2A, quando comparados a pacientes esporádicos, com risco relativo de óbito pela doença calculado em 7,74 a favor dos casos NEM2A. ${ }^{1}$ Ellenhorn et al., ${ }^{77}$ no entanto, não observaram evoluções distintas entre pacientes familiares e esporádicos, quando já portadores de doença metastática cervical, assim também como não o fizeram Hyer et al. ${ }^{11}$ Talvez as vantagens prognósticas dos pacientes tratados por CMTs NEM2A residam na oportunidade de diagnóstico mais precoce, o quê não ocorreu significativamente entre os nossos casos, inclusive quando diagnosticados através de rastreamentos. 
Apenas três pacientes foram diagnosticados através de USG cervical de rotina, o quê reduziu a confiabilidade de análises estatísticas correlatas. Os três casos provieram de consultório privado, onde a maioria dos portadores de tumores tireóideos é assintomática e comparece em função da realização de exames de rotina (“check up”). Uma paciente já apresentava metástases linfonodais cervicais e invasão vascular por tecido neoplásico, encontrando-se viva e com doença bioquímica ao final do seguimento. As duas outras pacientes encontravam-se vivas e sem doença. Caracterizaram-se por casos esporádicos e seus tumores primários foram estadiados como T1. Acredita-se que diagnósticos de neoplasias da tireóide através de USG de rotina tendam a aumentar, da mesma forma que diagnósticos de CMT-Fs através de programas de rastreamento. Em nosso estudo, análises estatísticas não demonstraram vantagens prognósticas na prática deste último quanto às condições clínicas finais ( $p$ $=0,4820)$, no entanto, observou-se que o mesmo pode oferecer tendência ao favorecimento das evoluções clínicas. Taxa de cura entre os pacientes rastreados foi calculada em 53,8\%, contra 33,3\% entre aqueles cujos diagnósticos de CMT foram realizados por outros meios. Uma paciente pertencente ao grupo de rastreados, porém, já apresentava doença avançada e inoperável ao diagnóstico, sendo responsável pelos $7,7 \%$ de taxa de óbito entre os integrantes desse grupo. Três casos familiares (dois NEM2A e um NEM2B) constituíram casos "index" (casos 13, 34 e 37). Eram duas mulheres ( 33 e 37 anos) e um menino de 10 anos, todos com exames físicos cervicais iniciais positivos e Estádio IVA. Uma paciente curou-se após a operação inicial, mas evolui com recidiva neoplásica e, ao término do seguimento, encontrava-se viva e com doença, como os outros dois pacientes. 
A grande vantagem da prática do rastreamento é o diagnóstico de acometidos sob estádios clínicos precoces, permitindo cura próxima a $100 \% .{ }^{9,10}$ Ezabella ${ }^{8}$ relatou diferença estatística marginal entre proporções de rastreados curados (40\%) e casos "index" familiares curados $(14,3 \%)$.

Em 75,7\% dos pacientes, nódulos tireóideos já eram palpáveis ao diagnóstico de CMT e 29,7\% já contavam com metástases linfonodais cervicais palpáveis. Foram caracterizados, portanto, 30 pacientes $(81,1 \%)$ com exames físicos cervicais iniciais positivos. São resultados próximos aos observados por Weber et al. ${ }^{94}$ que relataram $75 \%$ de nódulos tireóideos palpáveis e 14\% de adenomegalias cervicais metastáticas entre 36 pacientes diagnosticados. Em 162 pacientes atendidos entre 1949 e 1998, Hyer et al. ${ }^{11}$ contabilizaram $91 \%$ de acometidos por tumores cervicais palpáveis ao diagnóstico de CMT. Entre casos esporádicos, 74,2\% foram admitidos em vigência de tumores tireóideos, presente em $41,3 \%$ dos casos familiares, segundo relato de Kebebew et al. ${ }^{10}$ No presente estudo, $90,5 \%$ dos casos esporádicos já contavam com nódulos tireóideos e/ou adenomegalias metastáticas cervicais ao diagnóstico de CMT, enquanto $68,8 \%$ dos casos familiares os apresentavam (Tabela 12). Saad et al., 1 em publicação sobre estudo de 161 pacientes, relataram presença de nódulos tireóideos em 93,6\% e adenopatias cervicais em 52\% dos portadores de CMT-E, enquanto 48,4\% e 9,7\% dos pacientes CMT NEM2A já apresentavam nódulos tireóideos e adenomegalia cervical, respectivamente, aos exames físicos iniciais. Somente cinco pacientes caracterizados como CMT NEM2B participaram do trabalho, sendo que todos já apresentavam nódulos tireóideos palpáveis e, três, adenomegalias cervicais. Já se afirmou que pacientes com CMTs palpáveis frequentemente apresentam metástases linfonodais cervicais. ${ }^{63}$ 
Exame físico inicial positivo foi caracterizado como fator prognóstico negativo quanto à condição clínica final $(p=0,0017$, Tabela 20). Os sete pacientes que não apresentavam tumores primários e/ou metastáticos cervicais palpáveis, encontravamse vivos e sem doença ao final dos seguimentos, contra $26,7 \%$ (oito de 30 pacientes) entre aqueles cujos exames físicos cervicais iniciais foram positivos (Tabela 20). Todos os pacientes, portanto, cujas neoplasias persistiram ou recidivaram e que evoluíram vivos e com doença, ou faleceram, já apresentavam evidências clínicas de CMT à admissão (Tabelas 13 e 14). Todos aqueles que evoluíram com doença ativa evidente clínica e/ou imagenológica (13 pacientes) também foram caracterizados como portadores de exame físico inicial positivo.

Presença de sintomas ou sinais de CMT ao diagnóstico da neoplasia também constituiu fator prognóstico negativo em análise univariada de Kebebew et al. ${ }^{10}$ Talvez pelos achados clínicos aos exames físicos serem operador-dependentes, outras publicações consultadas não utilizaram esta variável em análises prognósticas.

Prontuários médicos de apenas sete pacientes (cinco CMT-E e dois CMT NEM2A), ou 18,9\% da casuística, faziam referências a sintomas sistêmicos (diarréia e/ou emagrecimento) ao diagnóstico de CMT, embora rubor facial e Síndrome de Cushing também possam ser manifestações correlatas. Diarréia já foi relatada por $28,8 \%$ dos pacientes esporádicos e por $6,5 \%$ dos pacientes familiares. ${ }^{1}$ Dores ósseas, rubor facial e/ou diarréia já foram observados em 10,3\% dos casos estudados, ${ }^{10}$ associados, em pacientes esporádicos, à identificação de metástases a distância. Os mesmos sintomas foram relatados por $6,5 \%$ dos pacientes familiares do mesmo estudo. 
Ocorrência de sintomas sistêmicos foi caracterizada como fator prognóstico pertinente à condição clínica final $(\mathrm{p}=0,0288$, Tabela 20$)$. Entre os sete pacientes que os referiam, quatro apresentavam metástases linfonodais cervicais e, entre estes, encontrava-se o único paciente em quem se caracterizou metástase distante à admissão. Dos quatro pacientes que faleceram, três referiam sintomas sistêmicos ao diagnóstico de CMT.

Sobrevida global já foi caracterizada como significativamente menor, sob análise univariada, entre os pacientes com diarréia, ${ }^{1}$ embora não se tenha observado significância desta variável à análise multivariada. Em outra publicação, ${ }^{10}$ todos os pacientes esporádicos com sintomas sistêmicos haviam sido classificados como Estádio IV e faleceram no decorrer dos seguimentos.

Em apenas um paciente relatou-se presença de metástase a distância (arco costal) ao diagnóstico de CMT. É provável que existissem outros casos, subestimados, talvez, pela não realização de exames rotineiros de imagem em órgãos comumente afetados por metástases distantes. No entanto, metástases hepáticas e pulmonares de CMT podem ser miliares e nem sempre se fazem notar em exames de imagem convencionais. ${ }^{10,63}$ Embora o paciente em questão tivesse falecido pela neoplasia, a presença de metástase a distância, ao diagnóstico de CMT, não obteve relevância prognóstica à analise estatística, quanto à condição clínica final $(\mathrm{p}=$ 0,1081, Tabela 22), contrariando a experiência de outros autores. ${ }^{9,11,95}$

Taxas de metástases a distância já foram relatadas entre $11,5 \%$ a $20 \%$ dos casos, à admissão. ${ }^{1,9,11,88}$ Segundo experiência de Kebebew et al., ${ }^{10}$ praticamente todos os pacientes com títulos sérios marcadamente elevados de CT após tratamento cirúrgico apropriado, apresentavam metástases a distância. No presente estudo, de 11 
pacientes que permaneceram após o tratamento operatório inicial com calcitonemias 100 vezes maiores que os limites superiores de referência, seis evoluíram com metástases a distância, observadas em mediastino, pulmões, fígado, cavidade abdominal, ossos do ombro e fêmur. Outros autores correlacionaram a presença de metástases a distância ao diagnóstico a risco quatro vezes maior de óbito, mas sem relação com sobrevida livre de doença. ${ }^{95}$ Sua influência sobre curvas de sobrevida foi observada também por Hyer et al. ${ }^{11}$

As modalidades terapêuticas empregadas não foram analisadas como fatores prognósticos em nosso estudo. Dos 37 pacientes revistos, apenas três (casos 3, 9 e 18) foram submetidos à totalização de tireoidectomias em segundo tempo operatório, uma vez que os diagnósticos de CMT haviam sido realizados por análises anatomopatológicas após os procedimentos cirúrgicos iniciais. Os pacientes relativos aos casos 3 e 9 encontravam-se vivos e sem doença ao final dos seguimentos, embora este último não retornasse ao ambulatório desde outubro de 1990, após seguimento de 67 meses. A paciente relativa ao caso 18 foi submetida a terceiro procedimento operatório para re-exploração cervical. Também perdeu seguimento clínico, após 84 meses de acompanhamento, e portava doença bioquímica no último retorno ambulatorial. Com exceção de um único artigo ${ }^{62}$ consultado, os autores são unânimes com relação à indicação de tireoidectomia total para tratamento de CMT. Os pacientes correspondentes aos casos 8 e 24 foram submetidos a ressecções parciais de suas neoplasias por serem considerados, no decorrer do tratamento operatório, casos inoperáveis. Os mesmos casos 3 e 9, citados anteriormente, também não foram submetidos a nenhum tipo de tratamento das cadeias linfonodais cervicais, talvez por ausência de padronização de condutas à época de seus tratamentos. Três 
outros pacientes (casos 28, 33 e 31) de nove, 14 e 16 anos, rastreados e portadores de CMTs NEM2A de $6 \mathrm{~mm}, 5 \mathrm{~mm}$ e $1 \mathrm{~mm}$ de diâmetro respectivamente, sem suspeitas de metástases linfonodais cervicais e com dosagens séricas basais de CT dentro dos limites da normalidade, foram submetidos somente à tireoidectomia total, certamente por se tratarem de pacientes jovens, assintomáticos, com calcitonemias basais dentro dos limites da normalidade e seus procedimentos operatórios terem sido considerados como pré-sintomáticos. Encontravam-se vivos e sem doença ao final da pesquisa, apesar de curtos períodos de seguimento (média de 41,7 meses). Dezenove pacientes $(51,4 \%)$ foram submetidos aos esvaziamentos central e lateral bilateral, sendo 10 destes indivíduos estadiados como N0, após análise anatomopatológica de suas peças operatórias. Doze pacientes $(32,4 \%)$ foram submetidos a outras modalidades de esvaziamentos cervicais, entre os quais 10 já apresentavam metástases linfonodais. Desta forma, a ausência de uniformidade de condutas cirúrgicas, em vigência de quadros clínicos muito distintos, não permitiu análise fidedigna da participação do tipo de tratamento operatório no prognóstico destes pacientes. Deve-se lembrar, porém, que terapias operatórias para o CMT devem englobar toda a neoplasia com obtenção de margens cirúrgicas livres de tumor, que o CMT não responde razoavelmente a terapias adjuvantes e que a propensão ao desenvolvimento de metástases cervicais é grande, com influência negativa sobre o prognóstico, como fortes argumentos à indicação da dissecção linfonodal eletiva, tanto para estadiamento, como para fins terapêuticos. ${ }^{6} \mathrm{~A}$ incompleta ressecção cirúrgica da neoplasia já foi associada a comprometimento prognóstico em outras publicações. ${ }^{9-11,77,95}$ 
Terapia complementar foi indicada para apenas quatro pacientes, todos em estádios avançados. O caso 12 evoluiu com doenças cervical, mediastinal e hepática, diagnosticadas 80 meses após o tratamento operatório inicial. Foi submetido a reexploração cervical e tratamento quimioterápico e seguia em acompanhamento clínico de 124 meses ao término da coleta de dados. Os três outros pacientes (casos 16, 22 e 24) faleceram pela doença após 88, 14 e 16 meses de seguimento, respectivamente. O paciente relativo ao caso 16 evoluiu com doença cervical inoperável, após oito meses do tratamento operatório inicial, seguida de metástases distantes em diversos sítios e sendo submetido a radioterapia em ombro. O paciente relativo ao caso 22 já apresentava metástases distantes ao diagnóstico de CMT. Evoluiu com metástases mediastinais e foi submetido a radioterapia externa. O último paciente foi considerado como inoperável ao procedimento cirúrgico inicial e logo evoluiu com neoplasias mediastinal e pulmonar, sendo submetido a tratamento quimioterápico, sem sucesso. Não pareceu sensato o estudo do valor prognóstico do emprego de terapias complementares.

Doze pacientes $(32,4 \%)$ apresentavam neoplasias primárias menores que 15 mm em seus maiores diâmetros e, 23 (62,2\%), neoplasias primárias maiores ou iguais a $15 \mathrm{~mm}$ em seus maiores diâmetros. Laudos anatomopatológicos referentes a dois casos não continham os diâmetros das lesões. Observou-se, portanto, que mais de $60 \%$ dos casos apresentavam tumores primários, provavelmente, passíveis de palpação (Tabela 6), considerando-se, arbitrariamente, tal medida como limite para a percepção de lesões tireóideas ao exame físico, embora os prontuários de 28 pacientes referissem presença de nódulos palpáveis. Dos 23 pacientes com neoplasias maiores ou iguais a $15 \mathrm{~mm}$ de diâmetro, $16(69,6 \%)$ já apresentavam metástases 
linfonodais cervicais, enquanto que cinco $(41,7 \%)$ já as portavam entre os 12 pacientes cujos tumores primários eram menores que $15 \mathrm{~mm}$ em seus maiores diâmetros, contando com lesões de 6, 9, 10, 12 e $13 \mathrm{~mm}$. Portanto, entre os 21 (56,8\% de todo o grupo) portadores de metástases linfonodais cervicais, apenas cinco (23,8\% de 21$)$ portavam tumores primários menores que $15 \mathrm{~mm}$. Os três pacientes cujos tumores alcançavam até $5 \mathrm{~mm}$ em seu maior diâmetro encontravam-se vivos e sem doença ao final dos seguimentos. Quarenta e cinco por cento (quatro de nove pacientes) cujos tumores eram maiores que $5 \mathrm{~mm}$, mas menores que $15 \mathrm{~mm}$, evoluíram com doença ativa, contra quase 74\% (17 de 23 pacientes) cujos tumores eram maiores ou iguais a $15 \mathrm{~mm}$ em seus maiores diâmetros. Entre os pacientes que faleceram, três haviam sido tratados por neoplasias primárias maiores que $30 \mathrm{~mm}$ e, o outro, por neoplasia de $15 \mathrm{~mm}$ em seu maior diâmetro (Tabela 21), todos já apresentando doença metastática cervical. Através de testes estatísticos, foi demonstrada significância de faixas de diâmetros das neoplasias primárias nas evoluções clínicas (cura e persistência ou recidiva, $\mathrm{p}=0,0249$, Tabela 27), porém, apenas tendência à sua participação nas condições clínicas finais $(p=0,0502$, Tabela 21).

Scopsi et al. ${ }^{95}$ correlacionaram progressivos diâmetros neoplásicos a maiores riscos de óbito, embora não tivessem notado correlação entre medidas tumorais e sobrevida livre de doença. Modigliani et al. ${ }^{9}$ associaram maiores taxas de sobrevida a diâmetros neoplásicos inferiores a $10 \mathrm{~mm}$. Correlações entre dimensões do tumor primário e evoluções também foram observadas por outros autores, ${ }^{11}$ mas Tavares, ${ }^{69}$ por sua vez, não observou correlação entre dimensões tumorais primárias e distribuição de metástases cervicais, bem como com resultado terapêutico. 
Multicentricidade tumoral foi observada em 21 casos (60\%). Destes, apenas seis foram classificados como casos esporádicos, correspondendo a $28,6 \%$ do grupo de CMT-E. Da mesma forma, hiperplasia de células "C" foi predominante entre os casos familiares $(75 \%)$, sendo observada em apenas três casos $(14,3 \%)$ esporádicos (Tabela 12). Laudos anatomopatológicos de 11 pacientes, entre os quais três casos eram familiares, não continham observações relativas à presença de HCC.

Kaserer et al. ${ }^{12}$ notificaram presença de hiperplasia de células " $C$ " concomitante à neoplasia em $71 \%$ dos CMT-Es estudados e 100\% de concomitância entre os casos familiares do grupo. Observaram correlação inversa entre diâmetro neoplásico e quantidade de células "C" no parênquima glandular, o que indicaria que a HCC pode regredir em vigência do crescimento do CMT-E. Sugeriram que, nos casos esporádicos, o estímulo inicial para o desenvolvimento de HCC parece diminuir com o crescimento da neoplasia e produção de maiores quantidades de calcitonina, em contraste com pacientes portadores de doença familiar, onde a proliferação de focos de células " $C$ " parece ser independente do crescimento neoplásico e comportar-se como neoplasias primárias, justificando, inclusive, a presença freqüente de multicentricidade tumoral. Esta foi identificada em $8,8 \%$ dos casos esporádicos e em $81,3 \%$ dos familiares por estes autores e em $19 \%$ dos casos esporádicos e em $90 \%$ dos casos familiares estudados por Weber et al., ${ }^{94}$ dados semelhantes aos observados no presente estudo. Scoposi et al. ${ }^{95}$ a identificaram em $25 \%$ de 76 casos esporádicos e Saad et al. ${ }^{1}$ observaram $31,6 \%$ e $94,4 \%$ de multifocalidade entre casos esporádicos e familiares, respectivamente. 
Multicentricidade tumoral e hiperplasia de células "C" não foram caracterizadas como fatores prognósticos relevantes à evolução ou condição clínica final (Tabelas 21 e 27), assim também como observaram outros autores. ${ }^{11,69,95}$

Extensões neoplásicas para a cápsula tireóidea, para estruturas adjacentes à glândula e para estruturas angiolinfáticas foram observadas em 35,1\%, 13,5\% e 40,9\% dos casos, respectivamente, embora 22 laudos anatomopatológicos não fizessem considerações a esse último aspecto (Tabela 6). Dos 13 pacientes cujos tumores atingiam a cápsula da tireóide, 11 apresentavam metástases linfonodais cervicais. Extensões para a cápsula da glândula ou tecidos adjacentes não dependeram dos diâmetros dos respectivos tumores, observando-se lesões primárias com $10 \mathrm{~mm}, 13 \mathrm{~mm}$ e $15 \mathrm{~mm}$ já com extensões capsulares. Invasões capsulares e para estruturas adjacentes à glândula já foram relatadas em $51 \%$ e 22,5\% respectivamente ${ }^{95}$ e em $23 \%{ }^{11}$ e $17,2 \%{ }^{6}$ como extensões extraglandulares.

As três variáveis clinicopatológicas acima puderam ser estatisticamente correlacionadas com as condições clínicas finais, especialmente os dados relativos à extensão neoplásica para tecidos adjacentes à tireóide $(\mathrm{p}=0,0024$, Tabela 21). Nenhum paciente com tal característica curou-se, embora um tenha evoluído com recidiva após cura pós-operatória. Entre os quatro indivíduos que faleceram, três portavam tumores com extensões para além da glândula. Entre os 13 pacientes cujos tumores atingiam a cápsula tireóidea, apenas dois $(15,4 \%)$ evoluíram sem doença, três $(23,1 \%)$ faleceram e os demais estavam vivos, mas com doença, ao final dos seguimentos clínicos. Entre os 13 pacientes cujas neoplasias não avançavam sobre estruturas angiolinfáticas, nove $(69,2 \%)$ encontravam-se vivos e sem doença ao final dos seguimentos, contra um paciente $(11,1 \%)$ entre nove acometidos por extensões 
vasculares. Em um paciente que faleceu, extensões vasculares foram observadas, porém os outros três que evoluíram da mesma forma não contaram com notas a este respeito em seus prontuários médicos. Ao final dos seguimentos, 77,8\% (sete de nove pacientes) daqueles com extensões neoplásicas vasculares estavam vivos, mas com doença, enquanto que apenas 30,8\% (quatro de 13 pacientes) assim se encontravam entre aqueles sem extensões vasculares caracterizadas. (Tabelas 13, 14 e 21).

Infiltração de tecidos adjacentes à glândula tireóide pelo tumor já foi associada a riscos relativos de progressão da doença e óbito de 4,6 e oito vezes, respectivamente, em relação àqueles com cápsula intacta, variável esta considerada como fator prognóstico negativo de maior relevância em estudo. ${ }^{95}$ Nenhum paciente portador de doença extraglandular evoluiu com cura bioquímica, em casuísticas de Gimm et al. ${ }^{88}$ e Weber et al. ${ }^{94}$ e a variável também foi considerada como fator prognóstico de sobrevida em estudo com 499 casos de CMT, onde, de sete pacientes que faleceram entre 21 portadores de CMT NEM2B, seis portavam neoplasias primárias Estádio T4 e, portanto, com invasão de estruturas adjacentes à glândula. ${ }^{64}$

Presença de substância amilóide junto ao tumor primário foi observada em 56,8\% dos espécimes estudados (Tabela 6). Saad et al. ${ }^{1}$ a identificaram em 90,4\% de 94 pacientes, Scopsi et al., ${ }^{95}$ em $78 \%$ de 109 casos esporádicos analisados, enquanto Kaserer et al. ${ }^{12}$ a identificaram em $34 \%$ dos casos estudados. Sua presença, ou ausência, não interferiu nas condições clínicas finais dos pacientes estudados no presente trabalho $(\mathrm{p}=0,8979$, Tabela 22$)$. As proporções entre os dois grupos foram semelhantes quanto às possíveis formas de evolução clínica $(p=0,7285$, Tabela 27), embora a ausência de substância amilóide já tenha sido associada a maior risco de 
progressão do CMT. ${ }^{95,160}$ Outros preditivos histológicos de sobrevida ou bom prognóstico já foram caracterizados como ausência de desmoplasia no estroma tumoral, ${ }^{12}$ ausência de necrose tumoral, maior proporção de células neoplásicas coradas por $\mathrm{CT}$ à $\mathrm{IH}$, ausências de células oxifílicas e padrão arquitetural escamoso, ${ }^{159}$ mas não foram analisados em nosso estudo.

Metástases linfonodais cervicais foram identificadas em 21 pacientes (56,8\%), com 47,6\% de extensão da neoplasia para além dos limites linfonodais (Tabela 7). Entre 23 pacientes com tumores primários potencialmente palpáveis, ou maiores ou iguais a $15 \mathrm{~mm}$ de diâmetro, $16(69,6 \%)$ apresentavam metástases cervicais, porcentagem inferior à observada por Tissel et al. ${ }^{67}$ (cerca de $90 \%$ ). Ao se considerar notas referentes aos exames físicos iniciais dos pacientes, 28 contavam com nódulos tireóideos palpáveis à admissão, entre os quais 19 (67,9\%) já apresentavam metástases linfonodais cervicais à análise anatomopatológica de seus produtos operatórios. Entre os 12 pacientes com tumores menores que $15 \mathrm{~mm}$ de diâmetro, cinco $(41,7 \%)$ já apresentavam metástases cervicais, sendo seis milímetros o menor diâmetro neoplásico primário associado à sua presença, neste grupo. Gimm et al. ${ }^{88}$ observaram correlação positiva entre acometimento linfonodal e estádios " $T$ " dos respectivos tumores primários e todos os pacientes portadores de neoplasias primárias Estádios T3 ou T4 exibiam metástases linfonodais, cuja presença não teve correlação com idade ou gênero. Observação semelhante foi realizada em nosso estudo, embora 15 pacientes, já com doença metastática, portassem tumores Estádios T1 ou T2, o quê, no entanto, inclui neoplasias com até $40 \mathrm{~mm}$ de diâmetro (ANEXO A). Em estudo de Weber et al., ${ }^{94}$ todos os pacientes sem envolvimento de linfonodos cervicais, contaram com tumores primários estadiados como T1 ou T2. 
Acometimento metastático de linfonodos cervicais já foi observado em $63 \%$ de 162 casos, ${ }^{11}$ em 16\% de 50 casos de microcarcinomas $(<10 \mathrm{~mm})$ medulares da tireóide, ${ }^{12}$ em $75 \%$ de 36 casos, ${ }^{94}$ em $27,9 \%$ de 499 casos, ${ }^{6}$ em $71,5 \%$ de 102 casos, ${ }^{95} \mathrm{com}$ $77 \%$ de extensão além dos limites linfonodais e em $67 \%$ de 27 portadores de CMTE. ${ }^{88}$

Presença de metástases linfonodais cervicais foi caracterizada como importante fator prognóstico às condições clínicas finais dos pacientes estudados $(\mathrm{p}<$ 0,0001, Tabela 22). Os quatro pacientes do grupo que faleceram as apresentavam e apenas dois casos $(9,5 \%$ de 21 pacientes $)$ portadores de acometimento metastático cervical foram curados. Entre os que evoluíram vivos, mas com doença, mais de 80\% apresentavam metástases cervicais ao tratamento operatório inicial (Tabelas 14 e 22). Entre os pacientes inicialmente curados, $25 \%$ portavam metástases linfonodais, entre aqueles cujas neoplasias recidivaram, $60 \%$ as portavam, observadas em $94,1 \%$ entre aqueles cujos tumores persistiram (Tabela 13). Risco relativo de persistência ou recidiva foi calculado em 4,82 (intervalo de confiança: 1,72 a 13,51) para os portadores de metástases cervicais, em relação àqueles livres de acometimento linfonodal. Todos os indivíduos que evoluíram com evidências clínicas e/ou imagenológicas de neoplasias local e/ou a distância haviam sido caracterizados como portadores de pescoços positivos para metástases de CMT, ao estadiamento inicial.

Acometimento metastático cervical já foi associado a riscos aumentados de progressão neoplásica e comprometimento prognóstico. ${ }^{6,9-11,69,95}$ Seus efeitos negativos sobre evoluções clínicas aumentaram com bilateralidade e acometimento de linfonodos mediastinais. ${ }^{11}$ Cura já foi observada em $89 \%$ de pacientes Estádio N0, em contradição a 30\% entre aqueles já com metástases cervicais, diferença 
estatisticamente significativa, ${ }^{94}$ e Tavares ${ }^{69}$ calculou a possibilidade de cura de doente sem metástase cervical como sendo 23,8 vezes maior que para portador de doença metastática.

Extensão neoplásica para além dos limites linfonodais não se caracterizou como fator prognóstico, através de cálculos estatísticos $(\mathrm{p}=0,3270$, quanto às condições clínicas finais, Tabela 22), embora nenhum paciente que a tivesse apresentado estivesse curado ao final dos seguimentos. Tal aspecto foi observado em três pacientes falecidos e em $46,7 \%$ (sete de 15 pacientes) dentre aqueles que se encontravam com doença ativa ao término dos seguimentos (Tabelas 14 e 22). Um único paciente com extensões tumorais para além dos limites linfonodais curou-se após o procedimento cirúrgico inicial, porém sua neoplasia recidivou (Tabela 13).

Saad et al., ${ }^{1}$ por sua vez, não observaram comprometimento das taxas de sobrevida entre pacientes portadores de metástases cervicais, porém extensões neoplásicas para além dos limites linfonodais representaram sinais de mau prognóstico, como também observado por outros autores. ${ }^{77}$ Scopsi et al. ${ }^{95}$ não observaram associação desta variável com riscos aumentados de óbito ou progressão da neoplasia.

Mais da metade $(51,5 \%)$ dos pacientes estudados foi classificada como Estádio IV, através do Sistema "TNM" (ANEXO A), indicando presença de neoplasias em estádios avançados de evolução (Tabela 7). Dois pacientes não puderam ser estadiados por ausência de dados para tal. Predomínio de pacientes admitidos em vigência de CMTs avançados não é exclusividade de nossa casuística. 9,11,15,94 Somente o diagnóstico precoce pode inverter essa situação e este depende de programas factíveis de rastreamento e da busca ativa de portadores desta neoplasia 
entre indivíduos com nódulos tireóideos. No entanto, observa-se que entre 13 pacientes diagnosticados através de rastreamento, cinco já se caracterizaram como Estádio IV e uma paciente, entre três, cujos diagnósticos deram-se através de achados ultra-sonográficos, já como Estádio IV também, apesar da neoplasia primária ter sido classificada como T1. Henry et al. ${ }^{73}$ observaram taxas de cura de 100\% entre 11 pacientes portadores de CMTs subclínicos, cujas suspeitas diagnósticas foram feitas a partir, somente, de dosagens séricas elevadas de calcitonina. As lesões primárias variaram de $1,2 \mathrm{~mm}$ a $9 \mathrm{~mm}$ de diâmetro e nenhum paciente apresentava doença linfonodal.

Em nosso grupo, só faleceram pacientes classificados como Estádio IV, embora dois pacientes, casos 17 (T3N1bM0) e 36 (T1N1bM0), entre 18 Estádios IV, estivessem vivos e sem doença após quatro e sessenta meses de seguimento, respectivamente. A cura do primeiro caso, porém, foi determinada somente através de dosagem basal de CT sérica e a paciente, esporádica e de 34 anos ao diagnóstico, não retornava às consultas desde março de 1990. Doze pacientes Estádios I, II ou III (70,6\% de 17) estavam vivos e sem doença ao final dos seguimentos e 72,7\% (16 entre 22 pacientes), cujos tumores persistiram ou recidivaram, haviam sido agrupados como Estádio IV. Portanto, quanto maior o estádio, menor a possibilidade de cura (Tabelas 13 e 14), dados respaldados por análises estatísticas que confirmaram a pertinência do Estadiamento TNM nas possíveis formas de evolução ( $p<0,0001$, teste Exato de Fisher) e condições clínicas finais $(p=0,0005$, Tabela 22), lembrando que o estadiamento não foi possível para dois pacientes.

Autores consultados ${ }^{1,7-10,69,88}$ também puderam considerar o Estadiamento TNM como fator prognóstico bastante relevante, inclusive sobre outras variáveis 
estudadas, validando esta forma de estadiamento para casos de carcinomas medulares da tireóide.

Após o tratamento operatório inicial, 20 pacientes (54\%) foram considerados como curados, por normalização de seus valores séricos de calcitonina (Tabela 9). Cinco pacientes $(13,5 \%$ do grupo ou $25 \%$ entre os inicialmente curados) evoluíram com recidivas neoplásicas, a partir do sexto mês de normalização pós-operatória dos níveis séricos de CT. Dezessete pacientes $(45,9 \%)$, portanto, mantiveram doença ativa após o tratamento inicial. Dez pacientes (45,5\% entre os 22 com doença ativa) evoluíram somente com doença bioquímica, sem evidências clínicas ou imagenológicas de neoplasia e em 12 casos $(54,5 \%)$ foram caracterizadas presenças de neoplasias persistente ou recidivante em região cervical e/ou metástases a distância (Tabela 11). Nenhum destes 22 indivíduos veio a curar-se posteriormente (Tabelas 13,14 e 26), apesar de re-operações ou terapias adjuvantes, dado compatível com experiências de outros autores. ${ }^{77}$ Pellegriti et al. ${ }^{15}$ observaram $44 \%$ de persistências após tratamento cirúrgico inicial (28 entre 63 pacientes). Dezoito (64,3\% de 28 ) evoluíram com evidências imagenológicas de doença cervical e/ou a distância e cinco pacientes faleceram, todos com evidências imagenológicas de neoplasia, dados muito semelhantes aos observados por nós. Estádio clínico, estádio $\mathrm{T}$ patológico, estádio $\mathrm{N}$ patológico, porcentagem de linfonodos metastáticos e títulos basais de CT no pós-operatório foram fatores prognósticos para evolução com evidências imagenológicas de neoplasia. ${ }^{15}$

Ao final dos seguimentos do presente estudo, 15 pacientes $(40,5 \%)$ encontravam-se vivos e sem doença, 18 (48,6\%) encontravam-se vivos e com doença e quatro $(10,8 \%)$ haviam falecido em decorrência do CMT. Entre 863 portadores de 
CMT, Modigliani et al. ${ }^{9}$ observaram 43\% de cura após tratamento operatório inicial, com taxa de recidiva de $2,1 \%$ em todo o grupo e $4,9 \%$ entre os inicialmente curados. Dez por cento foi a taxa de óbito observada. Dos 492 pacientes não curados pela operação, 249 não apresentavam indícios outros de doença persistente que não títulos séricos elevados de CT. Gimm et al. ${ }^{88}$ atribuíram elevados níveis séricos pósoperatórios de CT à presença de doença linfonodal remanescente, embora a verdadeira incidência de metástases hematogênicas não pudesse ser determinada. Observaram também que maiores possibilidades de cura ocorriam através do primeiro tratamento operatório $(56 \%)$. Kebebew et al. ${ }^{10}$ relataram taxa de $38,3 \%$ de persistências neoplásicas após o tratamento cirúrgico inicial (total de 104 pacientes), os quais sobreviveram por um mês a até 23,7 anos. Weber et al. ${ }^{94}$ observaram $44 \%$ de cura entre 36 pacientes, com recorrência imagenológica local identificada em 11\% do grupo (quatro pacientes). Destes quatro pacientes, três foram re-operados e apenas um alcançou cura bioquímica. Metástases a distância foram diagnosticadas em 11\% dos pacientes, no decorrer dos seguimentos. Dados, em sua maioria, também próximos aos observados por nós.

Em vigência de doença ativa, a forma como esta se manifestou representou fator prognóstico quanto à possibilidade de óbito ou sobrevida $(\mathrm{p}=0,0335$, Tabela 26). Dez pacientes evoluíram somente com evidências bioquímicas de CMT, ou seja, títulos séricos elevados de CT. Nenhum havia falecido até o final dos seguimentos. Entre os 12 pacientes que evoluíram com evidências clínicas e/ou imagenológicas de neoplasia cervical e/ou a distância, quatro faleceram $(33,3 \%)$. Os óbitos foram notificados após 14, 16, 19 e 88 meses de seguimento clínico. Autores ${ }^{95}$ observaram que $70 \%$ destes eventos ocorreram nos primeiros cinco anos do diagnóstico, como 
resultado de neoplasias localmente agressivas. ${ }^{77,95} \mathrm{Na}$ presente amostra, os pacientes que faleceram contavam com neoplasias cérvico-mediastinais avançadas, além de metástases distantes em três casos. Entre pacientes portadores de doença ativa, autores ${ }^{9}$ observaram sobrevida considerável (80,2\% em cinco anos e 70,3\% em 10 anos), com 18,1\% de óbitos em 10 anos.

Calcitonemias basais e níveis séricos de CEA, tanto ao diagnóstico do CMT, como no decorrer das evoluções clínicas dos pacientes estudados, foram muito diversos e nem todos os pacientes contaram com tais controles laboratoriais. Onze pacientes não contaram com dosagens iniciais de CT sérica e, em 19, dosagens séricas de CEA não foram relatadas em momento inicial. Os níveis séricos basais iniciais de CT variaram de valores normais (três pacientes rastreados) a 2240 vezes o limite superior laboratorial, com média de 138,6 vezes e desvio padrão e mediana calculados em 440,52 e 17,29 vezes, respectivamente. Tais valores indicaram variabilidade considerável, principalmente entre os pacientes com níveis bastante elevados do marcador. As mesmas considerações podem ser feitas para os títulos séricos iniciais de CEA, caracterizados por menor variabilidade, por sua vez.

Os três pacientes rastreados, que contaram com títulos séricos basais iniciais de CT dentro dos limites da normalidade, encontravam-se vivos e sem doença ao final de seus seguimentos. Outros dois pacientes apresentaram dosagens iniciais de CT até três vezes os limites laboratoriais. Um encontrava-se vivo e sem doença ao final do seguimento e, o outro, vivo e com doença cervical recidivada. Três pacientes, que ao final dos seguimentos encontravam-se vivos e sem doença, contaram com dosagens iniciais entre mais que três a 10 vezes os limites superiores, um com dosagem entre mais que 10 a 30 vezes e outro entre mais que 30 a 100 
vezes. Os três pacientes que faleceram, e que haviam sido submetidos a dosagens de CT ao diagnóstico, as apresentaram entre mais que três a 30 vezes os máximos valores laboratoriais $(4,11 ; 13,9$ e 27,9 vezes $)$. Os quatro pacientes que apresentaram dosagens iniciais de CT maiores que 100 vezes os máximos limites laboratoriais evoluíram com persistências tumorais, mas estavam vivos ao final dos seguimentos. Ao se analisar as faixas de valores séricos, observou-se que as proporções de vivos, mas com doença, ao final dos seguimentos, aumentaram com a progressão dos valores séricos iniciais do marcador (Tabelas 24 e 27). São dados que suportam a significância estatística ( $\mathrm{p}=0,0476$, Tabela 27) observada ao se comparar os valores iniciais de CT sérica com as evoluções observadas (cura e recidiva ou persistência neoplásicas), embora os pacientes falecidos tivessem apresentado títulos iniciais de CT não tão elevados.

No decorrer das evoluções clínicas, os 15 pacientes $(41,7 \%)$ que permaneceram com níveis séricos de CT dentro dos limites da normalidade foram considerados como curados e não foram observadas evidências clínicas de doença presente. Dez pacientes $(27,9 \%)$ evoluíram com níveis elevados em até 100 vezes os maiores limites laboratoriais e $11(30,6 \%)$ os mantiveram em valores maiores que 100 vezes. Destes últimos, nove apresentaram evidências clínicas ou imagenológicas de doença cervical e/ou a distância. Dos três pacientes que faleceram e que foram submetidos a dosagens séricas de CT, todos haviam evoluído com níveis maiores que 100 vezes os máximos valores de referência. Testes para cálculos de significância estatística quanto às condições clínicas finais não puderam ser realizados para esta variável, devido à presença de freqüências nulas ou demasiadamente baixas, no entanto, sua repercussão prognóstica nos pareceu pertinente (Tabela 24). Um 
paciente não contou com dosagens evolutivas de CT sérica, mas, em seu prontuário, observou-se referência a dosagem aumentada do marcador sob estímulo. Este paciente faleceu.

Saad et al. ${ }^{1}$ notaram tendência significativa a elevados títulos séricos de CT basal em pacientes portadores de tumores avançados, Van Heerden et al. 90 observaram excelente sobrevida a longo prazo entre pacientes com doença somente bioquímica e Ellenhorn et al., ${ }^{77}$ por sua vez, observaram casos isolados, localmente avançados, com doença evidente e considerável sobrevida também a longo prazo. Estes mesmos autores não observaram correlação entre níveis absolutos de CT sérica e prognóstico, porém a sua não redução pós-operatória indicou comprometimento evolutivo. Outros autores ${ }^{160,161}$ identificaram os níveis séricos pré e pós-operatórios de CT como elementos preditivos de evolução e observaram que todos os pacientes não curados apresentavam níveis séricos basais de CT elevados, em momento préoperatório, além da presença de neoplasia macroscópica e metástases cervicais. ${ }^{161}$

De 18 pacientes submetidos a dosagens iniciais de CEA, seis as apresentaram dentro dos limites de normalidade, apesar da presença de CMT, fatal em um dos casos, inclusive. Cinco pacientes apresentavam dosagens iniciais maiores que 10 vezes o máximo limite laboratorial, com dois casos de cura neste grupo (Tabela 25). Em nenhum caso observou-se dosagem elevada deste marcador, tanto inicial, como evolutiva, sem outras evidências de neoplasia e em todos os casos em que tais valores encontravam-se elevados, doença bioquímica, no mínimo, foi identificada, como também observado por outros autores. ${ }^{15}$ No entanto, nove pacientes que evoluíram com doença ativa, entre os 19 nos quais o marcador havia sido dosado, e sendo três com evidências clínicas e imagenológicas de neoplasia cervical e 
metastática a distância, incluindo um caso de óbito, o fizeram em vigência de títulos séricos de CEA dentro dos limites da normalidade, tornando relativo, portanto, o valor negativo deste marcador. Não se pode correlacionar os valores séricos iniciais de CEA com condições clínicas finais, em função de elevado número de freqüências nulas ou baixas e não se observou correlação estatística entre valores relativos iniciais de CEA e evoluções clínicas ( $\mathrm{p}=0,4899$, Tabela 27). Tal análise, porém, foi prejudicada pela não quantificação deste marcador sérico em muitos pacientes.

Modigliani et al. ${ }^{9}$ consideraram valores séricos pré-operatórios normais de CEA como preditores de cura e os correlacionaram com estádios patológicos. Já, Ezabella ${ }^{8}$ não observou correlação estatística entre títulos séricos pré-operatórios de CT e CEA e número de linfonodos cervicais acometidos pelo CMT.

As análises de sobrevida livre de doença e sobrevida global indicaram probabilidades de cura insatisfatórias, reduzidas com o decorrer do tempo de seguimento, especialmente no primeiro ano de acompanhamento clínico, quando a probabilidade de sobrevida livre de doença foi calculada em menos que 0,5. Já, as probabilidades de sobrevida global são altas, mesmo após anos de seguimento. O óbito mais precoce na presente casuística ocorreu após 14 meses do tratamento operatório inicial. Seguiram ocorrências aos 16, 19 e 88 meses de seguimento, com probabilidade de sobrevida de 0,83 aos 15 anos de seguimento (Tabelas 37 e 38, Gráficos 2 e 3). São dados compatíveis com os observados por outros autores. 


\subsection{VARIÁVEIS RELACIONADAS ÀS MARCAÇÕES IMUNO- HISTOQUÍMICAS PARA METALOPROTEINASES}

A identificação, a partir de adequada compreensão do comportamento biológico dos tumores, de pacientes sob risco de persistência ou recidiva é essencial, inclusive para a adaptação de condutas terapêuticas aos fatores prognósticos identificados. Daí o esforço do presente trabalho, que tentou identificar novos fatores prognósticos que pudessem orientar os seguimentos clínicos de pacientes afetados pelo CMT, embora caracterizados como fatores histológicos e, portanto, pósoperatórios, que não orientarão condutas terapêuticas iniciais. Segundo Kim et al., ${ }^{41}$ poderá ser possível a identificação de marcadores genéticos (oncogenes) que ofereçam informações prognósticas adicionais e prévias a qualquer tratamento empírico, ou seja, baseado em experiências anteriores com outros pacientes ou modelos estatísticos.

Como já foi demonstrado, o prognóstico de pacientes acometidos pelo carcinoma medular da tireóide é muito variável, mesmo na presença de doenças cervical e/ou metastática evidentes. Variáveis clinicopatológicas talvez sejam suficientes para determinações de prognóstico, porém, a grande diversidade de possíveis evoluções clínicas nos obriga a buscar observações complementares.

A participação de metaloproteinases na carcinogênese vem sendo extensamente documentada, embora suas atividades e respectivas conseqüências ainda não tenham sido completamente elucidadas, apesar de serem enzimas conhecidas há mais de 30 anos. Não se pode deixar de inferir que o objetivo final de 
linhas correlatas de pesquisa seja a contribuição, por menor que seja, ao desenvolvimento de modalidades terapêuticas que possam auxiliar a cura e o controle da progressão da doença, ou então, sob óptica mais realista e imediata, a seleção de candidatos a beneficiar-se de condutas terapêuticas mais agressivas e que demandem de maior atenção ao longo de seus seguimentos. No entanto, antes de se alcançar este objetivo final, a participação das enzimas em questão deve ser comprovada como pertinente ao comportamento biológico do câncer em órgão alvo.

Apenas duas linhas de pesquisa ${ }^{37,125}$ estudaram MMPs especificamente no carcinoma medular da tireóide, contando com 22 e 13 casos respectivamente, até a última revisão bibliográfica realizada em fevereiro de 2005 . Outros estudos, por sua vez, também incluíram em suas linhas de pesquisa espécimes de CMT, mas em amostras pequenas, que exemplificaram a presença de MMPs em tecido tumoral, sem representatividade estatística, porém.

Outros trabalhos 36,123-6,130,162-4 já demonstraram a presença das enzimas escolhidas para este estudo em tecido tireóideo, não necessariamente derivado de células “C”, enfatiza-se.

Entre 23 espécimes de carcinomas da tireóide (papilíferos, foliculares e anaplásicos), 18 apresentaram expressões de mRNA relativo à MMP-2, identificadas como intensas em fibroblastos adjacentes ou próximos às células neoplásicas, especialmente em linhas de invasão tumoral. Em adenomas foliculares não se observou marcação correspondente. ${ }^{124}$ Entre várias MMPs (MMP-1, -2, -3, 7, -8, -9 e -13) pesquisadas por Nakamura et al., ${ }^{123}$ apenas MMP-2 foi identificada sob níveis significativamente elevados em espécimes de carcinomas papilíferos, quando comparados com adenomas foliculares e controles. Expressões IH de TIMP-1 e 
MT1-MMP foram também marcadamente maiores nos tecidos neoplásicos. Expressões de outros possíveis marcadores (MT2-MMP, MT3-MMP e TIMP-2) foram menos relevantes. Imunomarcações para MT1-MMP e MMP-2 foram demonstradas tanto em células neoplásicas, como em células do estroma e colorações menos intensas ou ausentes foram observadas em parênquima normal. Forte atividade gelatinolítica estava presente em tecido tumoral, em menor intensidade no estroma adjacente às células neoplásicas e ausente em tecido normal, distribuições consistentes com as imunolocalizações das enzimas citadas e, portanto, com as atividades a elas atribuídas. ${ }^{123}$ Em fibroblastos derivados de tireócitos, já se identificou presença de mRNA de MT1-MMP, assim como altos níveis de mRNA de MMP-2 em culturas celulares epiteliais altamente purificadas de tireóide humana, células derivadas de carcinomas tireóideos e, especialmente, fibroblastos derivados de tireócitos. Altos níveis de mRNA de TIMP-2 também foram identificados em todos os tipos celulares estudados, enfatizando seu possível papel nos processos de proliferação celular, além da inibição de MMPs. ${ }^{162}$ Patel et al. ${ }^{163}$ identificaram expressões IH similares de MT1-MMP e TIMP-1 em lesões benignas e malignas da tireóide (carcinomas papilífero e folicular) de crianças e adolescentes, embora carcinomas papilíferos recorrentes apresentassem níveis inferiores de TIMP-1, quando comparados com aqueles não recorrentes. Baldini et al. ${ }^{164}$ testaram diferentes MMPs em linhas celulares correspondentes a neoplasias tireóideas, mas também não incluíram espécimes de CMTs. Observaram expressões de MMP-2 aumentadas, através de estudo de atividade gelatinolítica, em todas as linhas neoplásicas. 
Tomita ${ }^{125}$ selecionou três casos de HCCs e 10 espécimes de CMTs que corou, através de IH, com anticorpos para MMP-2 e -9 e TIMP-1 e -2. Incluiu tais enzimas no rol de marcadores de células neuroendócrinas, inclusive células " $\mathrm{C}$ " da tireóide, fortemente coradas pelos anticorpos, não identificando coloração nas células foliculares da glândula. Observou que células " $C$ " não-patológicas apresentavam tendências a maior coloração para MMPs que células "C" neoplásicas, enquanto que células neoplásicas também apresentavam menor coloração para TIMPs, a partir da onde sugeriu a importância do "balanço" entre MMP e seu inibidor específico (TIMP). Em metade das neoplasias estudadas, a coloração para MMP foi tão intensa quanto para células "C" não-patológicas, sugerindo, também, irregularidade de imunomarcações entre os casos de carcinoma medular. Ressalta-se, porém, que a amostra estudada foi pouco representativa, embora o pioneirismo desta publicação de 1997 contribua com sua importância.

Ao participarem da degradação da matriz extracelular e de interações entre células e esta matriz, acredita-se que as MMPs possam contribuir com a proliferação, invasão e metástases de células neoplásicas, além de modularem a angiogênese induzida pelas mesmas e, enfim, participarem de processos de sinalização para a progressão tumoral. Suas contribuições, entretanto, variam a depender do estádio de desenvolvimento tumoral. Acredita-se que suas participações reduzam-se em tumores já estabelecidos, justificando, inclusive, a inabilidade das drogas inibidoras de MMPs, já desenvolvidas, em reduzirem neoplasias de estádios avançados, sobre as quais a maioria dos estudos clínicos foram conduzidos. ${ }^{101}$ Diversos ensaios têm estudado a presença de MMPs individuais em diferentes tipos de tumores, através de diferentes técnicas investigativas, e vários estudos tentaram atribuir às MMPs 
significância prognóstica, mas utilizaram-se de números relativamente pequenos de casos e restringiram as pesquisas a poucos exemplares de MMPs. ${ }^{36}$

MMP-2, MT1-MMP e TIMP-2 são enzimas correlatas. As duas primeiras digerem diretamente componentes da MEC e ambas podem ser inibidas pelo TIMP2. Este último, por sua vez, também participa da ativação da MMP-2, através de formação de complexo molecular com as MT1-MMP e pró-MMP-2 na superfície celular. MT1-MMP, ao ativar outras MMPs, pode degradar, indiretamente, ampla gama de componentes da MEC, além de participar diretamente de frentes celulares de invasão. Conseqüências das atividades destas enzimas dependem mais das proporções entre as mesmas do que de suas concentrações absolutas. São, no entanto, mecanismos complexos e dependentes de outras substâncias, inclusive outras MMPs, também envolvidas em diferentes vias de ativação e inibição enzimáticas. Expressões de MT1-MMP e taxas de ativação de MMP-2 foram correlacionadas com comprometimento prognóstico em portadores de neoplasias ${ }^{101}$ e padrões de expressões gênicas das duas enzimas também foram demonstrados como intensamente correlatos. ${ }^{120,123,162}$

No presente estudo, optou-se por método imuno-histoquímico para identificação das metaloproteinases escolhidas nos espécimes neoplásicos selecionados. Constitui método pouco complexo para identificação de substâncias presentes em espécimes teciduais, ao fazer uso de anticorpos que devem ligar-se especificamente às substâncias que se pretende identificar. O resultado final é analisado sob microscopia ótica. As técnicas de coloração IH são padronizadas e reprodutíveis, acrescentando-se a elas diluições específicas para cada marcador, em função do recomendado pelo fornecedor e de experiências desenvolvidas no 
laboratório que abriga a pesquisa. O método permite o uso de espécimes incluídos em parafina, possibilitando, portanto, estudos retrospectivos e sob custo relativamente baixo, em relação a outras técnicas mais sofisticadas de identificação de substâncias e de seus materiais genéticos. Interfere, porém, no resultado final da coloração, a sensibilidade de proteínas à manipulação da peça operatória, como, por exemplo, o período em que o material permaneceu em solução de formol antes de sua inclusão em parafina, além do estado de conservação dos blocos incluídos neste material. Podem ser explicações às reações insatisfatórias observadas em alguns dos espécimes selecionados e que se mantiveram, apesar de repetidas tentativas de coloração.

Deficiência inerente ao método IH reside no fato da presença das substâncias estudadas, detectadas pelos anticorpos revelados, não necessariamente indicar que se tratam substâncias ativas, principalmente à análise de enzimas. Resta a dúvida se há correlação direta entre grau, quantitativo e qualitativo, de reação IH e atividade enzimática. Linhas de pesquisa validaram o método $\mathrm{IH}$, ao comparar resultados observados com aqueles obtidos por métodos mais sofisticados de biologia molecular. ${ }^{121,123,130}$ Estudos também propõem interpretações semiquantitativas e qualitativas das imunorreações, além de índices compostos. ${ }^{118,121,126,130}$

Como método "in situ", a IH permite a localização espacial da substância estudada em meio ao tecido neoplásico, diferente de outras técnicas que utilizam homogenados teciduais, embora não permita a identificação dos sítios de síntese da mesma e a determinação de se a imunorreatividade observada reflete genuíno incremento da expressão do material genético, relacionado à sua produção. Outras técnicas de biologia molecular, frequentemente empregadas, incluem hibridização 
"in situ" com fluorescência e zimigrafia "in situ", para análise de material genético tecidual, preservando-se sua arquitetura. "Northern blotting" para identificação de fragmentos específicos de RNA, "Southern blotting" para identificação de fragmentos específicos de DNA, zimografia em gelatina e ELISA são apenas exemplos de técnicas frequentemente citadas e que fazem uso de homogenados teciduais, quando o espécime analisado pode ser "contaminado" pelo material genético de células não-neoplásicas adjacentes ou incluídas em meio ao tumor, como células do estroma ou inflamatórias. Parece-nos que o ideal seria a combinação de métodos em mesmo fragmento tecidual. Discrepâncias também são observadas, quanto às localizações dos materiais pesquisados, em função da técnica laboratorial empregada, como demonstraram alguns autores. ${ }^{120,121}$

Outra questão envolvida no método escolhido inclui a subjetividade à análise das intensidades de coloração e análise semiquantitativa das áreas marcadas. Interpretações das imunomarcações por um mesmo observador talvez tenham minimizado tal desvantagem.

Em nosso estudo, não foi possível a comparação de marcação entre áreas neoplásicas e sadias, assim como entre centro e periferia dos tumores, pois nem sempre se contou com disponibilidade de áreas sadias adjacentes às neoplasias, assim também como com as orientações espaciais das mesmas. As localizações dos marcadores, por sua vez, puderam ser caracterizadas como estromais ou celulares.

O sistema de pontos proposto para o trabalho caracterizou, através de índices, faixas correspondentes às proporções de células (TIMP-2 e MT1-MMP) e áreas (MMP-2) coradas pelos marcadores e a intensidade das colorações em toda a extensão das lâminas analisadas. A soma dos dois índices resultou num "índice 
geral". A cada caso (tumor primário e metástase linfonodal cervical, quando presente) foram atribuídos valores referentes a estes três índices, para cada uma das três MMPs estudadas. Os pacientes foram então agrupados sob tais índices e os grupos obtidos confrontados com condições clínicas finais (vivo sem doença, vivo com doença ou morto pela doença) e evoluções iniciais (cura ou persistência). Os casos cujos espécimes foram classificados como "Índices 1" ou "2" foram agrupados em um mesmo segmento para o desenvolvimento de análises estatísticas.

À marcação para MMP-2, observou-se coloração do estroma tumoral e, em todos os casos, sua intensidade foi máxima. O anticorpo utilizado marcaria as formas ativa e latente da enzima, segundo seu fabricante. Observou-se correlação estatisticamente significativa entre "índice geral para tumor primário" e condições clínicas finais ( $\mathrm{p}=0,0005$, Tabela 28), como também com evoluções iniciais, após tratamentos operatórios $(\mathrm{p}=0,0207$, Tabela 29). Entre os pacientes que faleceram, dois contaram com "Índice Geral 2" para o tumor primário e, os outros dois, "Índice Geral 3". Corresponderam a 10,5\% e 11,8\% dos grupos "Índice Geral 1" ou "2"e “Índice Geral 3”, respectivamente. São proporções bastante próximas, embora um grupo de quatro pacientes, em número absoluto, seja pouco representativo. Entre 19 pacientes “Índice Geral 1" ou "2" para o tumor primário, $13(68,4 \%)$ estavam vivos e sem doença ao final dos seguimentos, contra dois $(11,8 \%)$, entre os 17 pacientes, do outro grupo. As proporções inverteram-se quanto aos pacientes vivos e com doença ao final dos seguimentos (Tabela 28). Observações semelhantes, e com significância estatística, foram realizadas quanto à cura ou persistência após o tratamento cirúrgico inicial, com benefício àqueles com menores índices de marcação para MMP-2. Ao estudo de proporção de área marcada nos espécimes primários, notou-se tendência ao 
favorecimento de condições clínicas finais $(p=0,0794)$ e evoluções iniciais $(p=$ 0,1461 ) entre aqueles “Índices 1 ” ou “2”. As análises das imunomarcações para os linfonodos metastáticos não proporcionaram significância estatística quanto às variáveis clínicas testadas.

Dezessete pacientes tiveram seus tumores primários classificados como “Índice Geral 3", contra 19, “Índice Geral 2". Todos os pacientes do primeiro grupo já apresentavam, à admissão, exames físicos cervicais positivos para a presença de lesão tireóidea e/ou metastática cervical, enquanto que 12 pacientes $(63,2 \%)$ do outro grupo os apresentavam, neste mesmo momento. Sintomas sistêmicos foram relatados por quatro indivíduos $(23,5 \%)$ do primeiro grupo e por três $(5,8 \%)$ do segundo. No grupo “Índice 3", extensão neoplásica para a cápsula tireóidea e invasão de estruturas adjacentes foram observadas em sete $(41,2 \%)$ e dois pacientes $(11,8 \%)$, respectivamente, enquanto que, para o outro grupo, tais proporções foram de $26,3 \%$ (cinco casos) e 5,3\% (um caso), respectivamente. Já, a presença de invasão neoplásica vascular foi identificada em seis pacientes $(35,3 \%)$ do primeiro grupo e em dois $(10,5 \%)$ do segundo. Doze pacientes $(70,6 \%)$ do grupo "Índice Geral 3" apresentavam metástases linfonodais cervicais e, um, já era portador de metástase a distância ao diagnóstico, contra oito pacientes $(42,1 \%)$ do segundo grupo, portadores de metástases linfonodais cervicais diagnosticadas. Dez pacientes $(58,8 \%)$ do grupo "Índice Geral 3" foram classificados como Estádio IV, enquanto que apenas sete $(36,8 \%)$ assim o foram no grupo "Índice Geral 2". Cura inicial, persistência e recidiva neoplásica foram observadas em seis $(35,3 \%), 11(64,7 \%)$ e quatro $(23,5 \%)$ indivíduos, respectivamente, para o primeiro grupo, contra taxas, para o segundo grupo, de 73,7\% (14 pacientes), 26,3\% (cinco pacientes) e 5,3\% (um paciente), 
respectivamente. No primeiro grupo, metástases a distância foram diagnosticadas em quatro pacientes $(23,5 \%)$ no decorrer de suas evoluções, sendo que nove $(52,9 \%)$ eram portadores de neoplasia cervical e/ou metastática ao final de seus seguimentos. Neste mesmo grupo, dois pacientes $(11,75 \%)$ foram considerados vivos e sem doença, 13 (76,5\%) vivos e com doença e, dois, mortos pela doença, ao final dos seguimentos. No outro grupo, dois pacientes evoluíram com neoplasias cervicais e a distância e, um, com somente metástases a distância, contabilizando 15,8\% de casos com evidências de neoplasia. Ao final dos seguimentos, $13(68,4 \%)$ estavam vivos e sem doença, quatro $(21,1 \%)$ estavam vivos e com doença e dois $(10,5 \%)$ haviam falecido. As proporções citadas podem justificar as significâncias estatísticas observadas, quanto aos prognósticos.

Entre os cinco pacientes curados, após seus procedimentos operatórios iniciais, e cujas neoplasias recidivaram, quatro apresentaram imunomarcações para tumores primários correspondentes ao "Índice Geral 3", inclusive os dois pacientes Estádios I e II iniciais, entre os quais, um evoluiu com evidências de doença cervical. Os espécimes primários de um paciente (caso 14) apresentaram marcações correspondentes ao “Índice Geral 2". Paciente este esporádico, Estádio IVA e que evoluiu com títulos séricos de CT maiores que 100 vezes os máximos limites de referência.

Correlações entre imunomarcações para MMP-2 nas neoplasias primárias e em seus correspondentes metastáticos linfonodais cervicais puderam ser realizadas para 18 casos. Em cinco (27,8\% de 18 casos), foram observadas discordâncias entre os "índices gerais" para os dois espécimes de mesmo paciente. Persistências foram observadas nesses cinco casos e dois faleceram. São ocorrências pequenas, que não 
permitem análises estatísticas fidedignas. Os trabalhos consultados não correlacionaram tais discordâncias às análises prognósticas realizadas, como também não correlacionaram as marcações das metástases. Apenas um paciente apresentou lesão metastática linfonodal mais reativa à MMP-2 do que seu tumor primário, em nossa amostra. Este paciente faleceu por metástases a distância. Não foram feitas também hipóteses factíveis relativas às causas de discordância nos artigos consultados. Talvez sejam indícios de que as metástases possam comportar-se de forma diferente que e independente de seus correspondentes primários, embora, através das análises realizadas nesta pesquisa, não se tenha observado correlações positivas entre imunoexpressões das MMPs pesquisadas nas metástases linfonodais e prognóstico.

Campo et al. ${ }^{126}$ observaram a distribuição de MMP-2, através de coloração $\mathrm{IH}$, em vários tecidos tireóideos, inclusive três espécimes de CMTs. Todos os espécimes de carcinomas (30 casos) e nove, de 11 espécimes de metástases, foram positivos para a marcação, com tendências a imunocolorações mais intensas entre neoplasias mais agressivas. A enzima também foi identificada em condições benignas, nas quais o tecido tireóideo sofria remodelação ou reparo, como na tireoidite de Hashimoto. As marcações ocorreram no citoplasma das células tireóideas, embora células do estroma também fossem coradas, especialmente em áreas de angiogênese. Padrões de reações foram semelhantes com o emprego de anticorpo específico ao peptídeo que confere latência à pró-MMP-2 e anticorpo contra peptídeo comum às formas latente e ativa da enzima, de tal forma que a MMP-2 encontrava-se sob forma inativa nestes tumores ou o domínio clivado, após ativação enzimática, permaneceria nas proximidades da MMP-2. 
Friguglietti et al. ${ }^{127}$ estudaram expressões IH de MMP-9, gelatinase, assim como a MMP-2, em células foliculares tireóideas. Observaram expressões progressivamente maiores no decorrer do processo de transformação celular, com máxima marcação observada em espécimes de carcinomas foliculares avançados.

Hofmann et al. ${ }^{162}$ atribuíram às células do estroma tumoral tireóideo as fontes principais de MMP-2 e MT1-MMP, a partir da identificação da presença de mRNA destas enzimas em linhas celulares correspondentes, derivadas de tecidos sadios e de carcinomas.

Nakamura et al. ${ }^{123}$ observaram taxas de ativação de pró-MMP-2 significativamente maiores em casos de carcinomas papilíferos com metástases linfonodais, embora níveis absolutos do marcador não estivessem correlacionados com doença linfonodal. Atribuíram à ativação da pró-MMP-2 papel fundamental no desenvolvimento de metástases.

Maeta et al. ${ }^{121}$ relataram imunocoloração citoplasmática para MMP-2 em 86 espécimes de carcinomas papilíferos, com padrão mais discreto em estroma, maior, porém, que em estroma sadio. Células foliculares, em áreas sadias, também foram positivas. As atividades enzimáticas, estimadas através das dimensões das áreas das bandas específicas em zimografia em gelatina e "Western blotting", foram significativamente maiores nos tecidos tumorais, em relação aos tecidos nãoneoplásicos, e equivalentes aos índices IH observados. Como em nosso trabalho, houve correlação significativa entre imunocoloração para MMP-2 e os aspectos clinicopatológicos: estádio “T”, presença de metástases linfonodais, estádio clínico e invasões intratireóidea e vascular, embora tenhamos correlacionado, através de análise de significâncias estatísticas, os padrões de marcação para MMP-2 com as 
formas de evolução e, estas últimas, com os aspectos clinicopatológicos. Os autores, diferentemente de nós, também constataram correlações significativas entre imunorreações para TIMP-2 e dimensões tumorais (ou estádio “T”), estádio TNM e invasões intratireóidea e vascular, com prejuízo aos pacientes com índices mais elevados de coloração ao TIMP-2. Apenas um caso apresentava metástases distantes, ocorrência insuficiente, como em nosso estudo, para análise de significância estatística. Atribuíram às células neoplásicas principal fonte de MMP-2 e -9 e TIMP1 e -2 neste carcinoma. Novamente, células "C" não foram consideradas.

Korem et al. ${ }^{130}$ observaram colorações citoplasmáticas fracas e moderadas para MMP-2 em quatro espécimes de CMTs. Entre controles, condições benignas, carcinomas foliculares e medulares, apenas em espécimes de carcinomas papilíferos da tireóide (12 casos) descreveram intensa imunorreação, também observada em componentes do estroma, especialmente em paredes dos vasos, áreas de fibrose e pericapsulares. Através de zimografia em gelatina e ELISA, também observaram maior representatividade da enzima entre os casos de carcinomas papilíferos, sem correlação, porém, com a presença de metástases linfonodais. Não se observou diferença significativa na atividade de MMP-2 entre os outros subgrupos de espécimes teciduais, incluindo os quatro casos de CMTs e não foram relatadas diferenças significativas nos níveis de TIMP-2 entre os espécimes estudados.

Cvejić et al. ${ }^{37}$ objetivaram determinar a imunolocalização de MMP-2 em carcinomas medulares da tireóide, através do estudo de 22 casos esporádicos. Os autores não citaram se o anticorpo utilizado era específico a alguma das formas de MMP-2, ou seja, ativa e/ou latente. Como em nosso estudo, todos os casos foram corados pelo marcador, no entanto, as marcações observadas localizaram-se 
difusamente no citoplasma das células neoplásicas, com intensidades variáveis entre moderado a forte. Coloração também foi observada no estroma dos espécimes, e, talvez, tenha sido menos significativa do que nas células " $C$ " neoplásicas devido à baixa celularidade estromal. Células foliculares não apresentaram marcações. As intensidades de coloração foram então cruzadas com os estádios clinicopatológicos iniciais. Não houve diferença estatística entre espécimes de pacientes Estádios N0 e N1 patológicos. A conclusão de que a imunocoloração para MMP-2 não oferece significância prognóstica ao CMT nos pareceu um pouco precipitada, uma vez que as análises das marcações restringiram-se às suas intensidades e as correlações anatomoclínicas limitaram-se ao Estádio TNM, no momento da operação, e forma das células dos tumores. A proporção entre MMP-2 e TIMP-2 também não foi considerada.

Colorações para MT1-MMP marcaram células neoplásicas. Correlações estatisticamente significativas somente foram obtidas para as evoluções iniciais (cura ou persistência) quanto à proporção de células marcadas no tumor primário $(\mathrm{p}=$ 0,0098, Tabela 31) e "índice geral” para a neoplasia primária $(\mathrm{p}=0,0216$, Tabela 31), com benefício àqueles pacientes com menores representações IH para MT1MMP. Entre os pacientes cujos tumores primários foram classificados como "Índices 1" ou “2" quanto à proporção de células neoplásicas primárias marcadas, 90\% curaram-se inicialmente, contra $40 \%$ entre aqueles "Índice 3". Já, entre os seis pacientes cujos "índices gerais" para neoplasia primária foram "1" ou "2", todos se curaram inicialmente, enquanto 44,8\% (13 de 19 pacientes) o fizeram entre aqueles “Índice Geral 3". Dos pacientes do primeiro grupo, porém, dois, casos 4 e 7, evoluíram com recidivas bioquímicas e metástase a distância (caso 7), encontrando- 
se vivos e com doença ao final dos seguimentos. Tendências a benefícios quanto às condições clínicas finais foram observadas entre os pacientes com menores proporções de coloração de células neoplásicas primárias, assim também como menores valores de "índices gerais” para tais lesões (Tabela 30). Análises de intensidades de coloração e índices relacionados às imunomarcações em metástases linfonodais não apresentaram correlações estatisticamente significativas quanto às variáveis evolutivas, escolhidas como indicadoras de prognóstico (Tabelas 30 e 31).

Vinte e nove pacientes tiveram seus tumores primários classificados como “Índice Geral 3” quanto à imunocoloração para MT1-MMP. Estes foram comparados com os demais, classificados como "Índice Geral 2" (seis pacientes). Ao diagnóstico de CMT, pacientes de ambos os grupos apresentavam exames físicos cervicais positivos em cerca de $80 \%$ dos casos (23 e cinco pacientes, respectivamente), embora nenhum caso “Índice Geral 2" portasse adenomegalia cervical ao diagnóstico. Extensão neoplásica para a cápsula tireóidea foi observada em 12 casos $(41,4 \%)$ entre os classificados como "Índice Geral 3" e em um caso do outro grupo (16,7\%). Entre os classificados como "Índice Geral 3", cinco pacientes apresentavam acometimento de estruturas adjacentes à tireóide, contra nenhum caso do segundo grupo. Invasão vascular foi observada em oito pacientes $(27,6 \%)$ entre aqueles do primeiro grupo e em nenhum do segundo, assim como nenhum, deste último, apresentou-se com metástases linfonodais cervicais, contra 69\% (20 pacientes) daqueles classificados como "Índice 3". Observa-se aí que todos os pacientes com metástases linfonodais cervicais, com exceção de um, cuja lesão metastática não foi avaliada, apresentaram tumores primários classificados como “Índice Geral 3” em relação à representação $\mathrm{IH}$ de MT1-MMP. O paciente que se apresentou com 
metástase a distância ao diagnóstico de CMT também fez parte deste último grupo, cujos pacientes contaram com $31 \%$ (nove casos) de cura inicial, sendo que três $(10,3 \%)$ apresentaram recidivas. Dez pacientes $(35,5 \%)$ evoluíram com indícios clínicos ou imagenológicos de doença cervical e/ou a distância e quatro $(13,8 \%)$ faleceram, estando $10(34,5 \%)$ vivos e sem doença ao final do estudo. Quanto àqueles agrupados sob “Índice 2", todos curaram-se logo após a operação, mas dois $(33,3 \%)$ apresentaram recidivas. Nenhum faleceu.

Entre os cinco pacientes cujas neoplasias recidivaram, um contou com "Índice 1" quanto à proporção de células coradas, dois, “Índice 2" e, dois, “Índice 3". Os espécimes primários de dois pacientes foram classificados como "Índice Geral 2" e os espécimes dos outros três, como "Índice Geral 3", para MT1-MMP.

Em 19 casos foi possível comparar índices de imunomarcação para MT1MMP, obtidos em lesões primárias, com correspondentes metastáticos linfonodais. Em seis casos $(31,6 \%)$ os "índices gerais" não foram semelhantes entre os dois espécimes de mesmo paciente, com menores índices de marcação para as metástases. Cinco apresentaram persistências e, o sexto paciente, cura inicial seguida de recidiva bioquímica. Um faleceu (caso 22) com metástases a distância e os demais se encontravam vivos e com doença ao final dos seguimentos, sendo dois com evidências clínicas de doença. Entre os outros 14 pacientes, quatro (28,6\%) curaramse inicialmente, dois $(14,3 \%)$ estavam vivos e sem doença ao final de seus seguimentos, dois faleceram pela doença e $10(71,4 \%)$ encontravam-se vivos e com doença. As mesmas considerações tecidas com relação às discordâncias de marcação para MMP-2 podem ser aqui inferidas. 
Expressões gênicas de MT-MMP já foram identificadas em células do estroma de carcinomas de cólon, mama, cabeça e pescoço ${ }^{119}$ e tireóide ${ }^{162}$ e, segundo Seiki, 101 as expressões de MT1-MMP nas células neoplásicas podem parecer ínfimas, quando comparadas às intensas marcações em estroma adjacente. Sua imunodetecção, entretanto, ocorre nas células tumorais, como inicialmente descrito em 1994, através do uso de anticorpos contra o domínio extracelular da enzima, ${ }^{165}$ indicando que esta pode ser clivada da superfície de células do estroma e ligada a receptores da membrana plasmática de células neoplásicas. ${ }^{119}$ Nakamura et al., ${ }^{123}$ por sua vez, observaram transcrições de MT1-MMP, através de hibridização "in situ”, em células neoplásicas e estromais de carcinomas papilíferos da tireóide. Os mesmos autores correlacionaram a expressão da proteína com a presença de metástases linfonodais. Níveis de transcrição de MT-MMP já foram observados como menores em espécimes de metástases de adenocarcinomas de cólon, quando comparados com os correspondentes primários. ${ }^{119}$

As imunomarcações para TIMP-2 também foram observadas nas células neoplásicas primárias e metastáticas. Nenhum dos índices propostos para este marcador foi estatisticamente associado a evoluções iniciais e condições clínicas finais (Tabelas 33 e 32). Nem mesmo tendências para tal foram observadas.

Vinte e nove pacientes $(85,3 \%$ entre aqueles cujos tumores primários foram estudados por este marcador) obtiveram “Índice Geral 3”, contra cinco, “Índice Geral 2” (Tabela 18). Entre os classificados como “Índice Geral 3” (neoplasia primária), 16 apresentavam nódulos tireóideos palpáveis, sete, nódulos tireóideos e adenomegalias metastáticas palpáveis e, um, somente adenomegalia metastática aos exames físicos iniciais, perfazendo $82,8 \%$ de pacientes com exames físicos positivos ao diagnóstico. 
No outro grupo, três $(60 \%)$ apresentavam exames físicos cervicais positivos à admissão, sendo um, inclusive, paciente portador de metástase para arco costal. No grupo "Índice Geral 3" para o tumor primário, dois pacientes não foram submetidos à tireoidectomia total por irressecabilidade, sendo diagnosticada extensão neoplásica para a cápsula tireóidea em 12 casos $(41,4 \%$ dos 29$)$ e, em quatro, para estruturas adjacentes à glândula. No outro grupo, um único caso (20\%) apresentou tumor com estas propriedades. Em sete casos $(24,1 \%)$ do grupo “Índice 3" observou-se invasão neoplásica vascular, contra um caso (20\%) no grupo “Índice 2". Dezessete pacientes do primeiro grupo já apresentavam metástases linfonodais cervicais à operação $(58,6 \%)$, proporção semelhante a do outro grupo (60\% ou três pacientes). Quinze pacientes $(51,7 \%)$ do primeiro grupo curaram-se inicialmente, com quatro casos posteriores de recidiva neoplásica. Seis pacientes evoluíram com evidências de neoplasias cervical e metastática a distância e, cinco, com evidências de doença local, com $11(38,0 \%)$ vivos sem doença, $15(51,7 \%)$ vivos com doença e três $(10,3 \%)$ mortos, ao final dos seguimentos. Entre aqueles "Índice Geral 2", três $(60 \%)$ apresentaram cura inicial e, os demais, persistências. Um paciente evoluiu com recidiva bioquímica e, ao final dos seguimentos, dois (40\%) encontravam-se vivos e sem doença, dois vivos e com doença e um (20\%) falecido por metástase a distância.

Quatro pacientes cujas neoplasias recidivaram contaram com marcações correspondentes ao "Índice Geral 3" para seus espécimes primários e, o quinto paciente, “Índice Geral 2". Discordância entre as imunomarcações para a neoplasia primária e seu correspondente metastático só foi observada entre espécimes de um caso. 
Ao identificarmos, através do "índice geral” proposto, correlação entre as imunomarcações para MMP-2 e as evoluções clínicas e, apesar de não encontrarmos evidências, através dos índices propostos, de participação de TIMP-2 na progressão do CMT, mesmo em vigência de imunomarcações expressivas para a proteína, tentamos atribuir a ela função inibitória da atividade da MMP-2, como inicialmente descrito e por sua própria definição. Dividindo-se os valores de "índices gerais" para MMP-2 pelos valores de "índices gerais" para TIMP-2, obteve-se um "índice relativo" para cada caso (referente às neoplasias primárias). Pacientes com "Índices Relativos" iguais a "1,0" apresentaram marcações equivalentes para as duas proteínas e aqueles com índices iguais a “ 0,7 ”, apresentaram, portanto, predomínio de marcação, e talvez de atividade, de TIMP-2 sobre MMP-2 em seus espécimes primários e, assim, possibilidade de serem portadores de neoplasias menos agressivas. Esta foi somente uma hipótese aventada, confirmada, porém, através de análise estatística que agrupou os pacientes sob os dois possíveis resultados citados e os comparou com condições clinicopatológicas envolvidas nas evoluções clínicas, segundo análise prévia das mesmas variáveis, além de condições clínicas finais. Foi observada 95\% (19 de 20 pacientes) de positividade ao exame físico cervical inicial entre os pacientes “Índice Relativo 1,0”, enquanto que 61,5\% (oito de 13) dos pacientes a apresentou no outro grupo $(\mathrm{p}=0,0248)$. Em nenhum paciente "Índice Relativo 0,7 ' diagnosticaram-se metástases cervicais após exame anatomopatológico de seus produtos operatórios, enquanto que 65\% (13 de 20) dos pacientes do outro grupo as apresentaram $(\mathrm{p}=0,0002)$. Quanto às condições clínicas finais, as proporções entre vivos sem doença, vivos com doença e mortos pela doença demonstraram favorecimento aos pacientes classificados como "Índice Relativo 0,7" 
$(\mathrm{p}=0,0149)$. Não se obteve significância estatística quanto à evolução inicial, embora predominassem casos de cura inicial no grupo "Índice Relativo 0,7" (69,2\%). Da mesma forma, predominaram pacientes Estádios I, II e III neste grupo (61,5\%), em oposição ao grupo de pacientes “Índice Relativo 1,0”, onde pacientes Estádio IV constituíram maioria (55,5\%). Entre aqueles “Índice Relativo 0,7”, 15,4\% apresentaram evidências clínicas e/ou imagenológicas de doença local e/ou a distância, proporção de 50,0\% entre pacientes do outro grupo (Tabela 34). São observações que favorecem, portanto, os pacientes cujos tumores primários sofreram maiores imunomarcações para TIMP-2, segundo o índice proposto, quando comparadas às marcações para MMP-2, indicando, talvez, maior atividade inibitória sobre os efeitos carcinogênicos da MMP-2. Paradoxalmente, porém, TIMPs podem não oferecer função de proteção contra neoplasias malignas e suas expressões já foram correlacionadas com comprometimento prognóstico ${ }^{36,118,134}$ ao também participarem de processos de proliferação celular. ${ }^{162}$

O mesmo raciocínio foi aplicado às proporções entre MT1-MMP e TIMP-2 e entre MMP-2 e MT1-MMP. Não se observou, porém, correlações estatísticas, ou mesmo tendências, com privilégio de algum dos grupos (dados não demonstrados e resultados individuais apresentados em ANEXO C).

Desenho de estudo semelhante ao nosso foi realizado por Davidson et al. ${ }^{116}$ que analisaram as mesmas MMPs em carcinomas de colo de útero. Além de estudo IH, utilizaram hibridização "in situ” para localização do mRNA das enzimas, seguindo análise clinicopatológica. À IH, MMP-2 foi localizada tanto em células neoplásicas como do estroma. Sua imunorreatividade foi significativamente mais frequente nas células tumorais, quando comparada com os sinais correspondes de seu 
mRNA, também presentes em ambos os tipos celulares. Presenças de mRNA de MMP-2 e TIMP-2 foram correlacionadas com estádios avançados e comprometimento prognóstico e os sinais correspondentes às duas enzimas também foram estatisticamente correlacionados entre si. Tais associações, porém, não foram observadas para os sinais correspondentes ao mRNA de MT1-MMP, presentes em ambos os tipos celulares, embora fossem negativos nas células do estroma de controles. Segundo os autores, MT1-MMP é, possivelmente, necessária para a ativação de MMP-2, mas os níveis desta última é que devem ditar a agressividade neoplásica. A presença de sinais intensos para mRNA de TIMP-2 em controles sadios, negativos para MMP-2, pôde refletir o papel protetor daquela enzima em tecidos não-neoplásicos.

Não nos cabe fazer suposições sobre as imunolocalizações das proteínas estudadas em nosso trabalho, inclusive porque não foram utilizados outros métodos laboratoriais de marcação para comparação. Da mesma forma, não temos meios de saber se os locais marcados corresponderam às áreas de produção e/ou de ação das enzimas. O quê nos interessou, realmente, foi se a enzima estava presente no tumor estudado e em qual extensão, o quê foi suposto em função dos cálculos de áreas imunocoradas e intensidade das reações. Correlações com dados clínicos fecharam a pesquisa, supondo-se que as áreas imunocoradas pelos anticorpos marcados correspondessem à presença de enzimas ativas. Os resultados obtidos validaram o emprego das MMPs selecionadas, através de detecção imuno-histoquímica, como marcadores prognósticos no carcinoma medular da glândula tireóide, levando-se em conta, logicamente, a forma de interpretação das imunorreações. 
7 CONCLUSÕES 


\section{CONCLUSÕES}

1 No estudo das variáveis clinicopatológicas, foram estatisticamente relevantes às condições clínicas finais dos pacientes (vivo sem doença, vivo com doença ou morto pela doença), com conotação desfavorável, as variáveis: presença de nódulos tireóideos e/ou adenomegalia metastática cervical ao exame físico inicial, presença de sintomas sistêmicos (diarréia e/ou emagrecimento), extensão neoplásica para a cápsula tireóidea, extensão neoplásica para tecidos além dos limites tireóideos, invasão neoplásica vascular, metástases linfonodais cervicais, estádios patológicos avançados e evidências clínicas ou imagenológicas de doenças cervical ou metastática a distância, durante as evoluções pós-operatórias. Não foram estatisticamente influentes, na condição clínica final, as variáveis clinicopatológicas: faixa etária ao diagnóstico, gênero, diagnóstico de carcinoma medular realizado em momento pré-operatório ou pós-operatório, diagnóstico de neoplasia como achado acidental de USG cervical, diagnóstico de carcinoma medular através de rastreamento, multicentricidade tumoral, presença de hiperplasia de células “C” em associação com CMT, presença de amilóide em meio ao tumor, presença de metástases a distância ao diagnóstico da neoplasia primária e forma clínica da doença (esporádica ou familiar). Títulos séricos de

calcitonina entre o momento do diagnóstico etiológico até o pós-operatório imediato e durante a evolução clínica, títulos séricos de CEA entre o momento do diagnóstico etiológico até o pós-operatório imediato e a elevação 
destes últimos, acompanhando persistência ou recidiva neoplásicas, não apresentaram correlações estatisticamente significativas com as condições clínicas finais.

2 No estudo de variáveis clinicopatológicas que não apresentaram correlações estatisticamente significativas com as condições clínicas finais, correlacionaram-se com as evoluções clínicas (cura e persistência ou recidiva) as variáveis: diâmetro neoplásico primário e títulos séricos iniciais de CT. Não foram identificadas correlações entre as evoluções clínicas e as variáveis: faixa etária ao diagnóstico de CMT, gênero, multicentricidade tumoral, presença de $\mathrm{HCC}$ em associação com CMT, presença de amilóide em meio ao tumor e títulos séricos iniciais de CEA.

3 As expressões imuno-histoquímicas de MMP-2 e MT1-MMP nos espécimes primários de carcinomas medulares da tireóide, bem como a razão entre as expressões imuno-histoquímicas de MMP-2 e TIMP-2, são preditivos de evolução clínica. Índice proposto que associa a proporção de área tumoral imunomarcada com a intensidade desta coloração ("índice geral” para tumor primário) foi estatisticamente correlacionado, quando aplicado à expressão $\mathrm{IH}$ de MMP-2, com as condições clínicas finais (vivo sem doença, vivo com doença e morto pela doença) e evoluções com cura ou persistência tumoral, após o tratamento cirúrgico inicial. O mesmo índice, quando aplicado à expressão IH de MT1-MMP, bem como a proporção de células neoplásicas coradas por este marcador, foi estatisticamente correlacionado com cura e 
persistência neoplásica, após o tratamento cirúrgico inicial. A razão entre os “índices gerais” para MMP-2 e TIMP-2 em tumor primário demonstrou que maior proporção de TIMP-2, sobre MMP-2, correlacionou-se estatisticamente com menores ocorrências de condições clínicas desfavoráveis. 
8 ANEXOS 


\begin{abstract}
ANEXO A - $\quad$ Sistema de Estadiamento TNM para o Carcinoma Medular da Tireóide, proposto pela “Union Internacionale Contre le Cancer” (UICC) e pela “American Joint Committee on Cancer” (AJCC), segundo edição do Manual de Estadiamento do Câncer da AJCC de $2002{ }^{73}$
\end{abstract}

\title{
Tumor Primário (T):
}

Tx - O tumor primário não pode ser a avaliado

T0 - Ausência de evidência de tumor primário

T1 - Tumor de $2 \mathrm{~cm}$ ou menos em seu maior diâmetro, limitado à tireóide

T2 - Tumor de mais de $2 \mathrm{~cm}$, mas não mais que $4 \mathrm{~cm}$, em seu maior diâmetro, limitado à tireóide

T3 - Tumor de mais de $4 \mathrm{~cm}$ em seu maior diâmetro e limitado à tireóide ou qualquer tumor com extensão extratireóidea mínima (ex.: extensão para músculo esternocleidomastóideo ou tecidos moles peritireóideos)

T4a - Tumor de qualquer diâmetro que se estende além da cápsula tireóidea e invade tecido celular subcutâneo, laringe, traquéia, esôfago ou nervo laríngeo recorrente

T4b - Tumor de qualquer diâmetro que invade fáscia pré-vertebral, envolve artéria carótida ou vasos mediastinais

\section{Linfonodos Regionais (N):}

$\mathrm{Nx}$ - Linfonodos regionais não podem ser avaliados

N0 - Ausência de metástases para linfonodos regionais

N1 - Metástases para linfonodos regionais: 


$$
\begin{aligned}
& \text { N1a } \quad \text { - } \quad \text { Metástase para linfonodos do nível VI } \\
& \text { N1b - } \quad \text { Metástase para linfonodos laterais unilaterais, bilaterais }
\end{aligned}
$$

ou contralaterais ou para os linfonodos do mediastino superior

\section{Metástases Distantes (M):}

Mx - Metástases a distância não podem ser avaliadas

M0 - Ausência de metástases a distância

M1 - Presença de metástases a distância

\section{Grupos de Estádios:}

$\begin{array}{lccc}\text { Estádio I } & \text { T1 } & \text { N0 } & \text { M0 } \\ \text { Estádio II } & \text { T2 } & \text { N0 } & \text { M0 } \\ \text { Estádio III } & \text { T3 } & \text { N0 } & \text { M0 } \\ & \text { T1 } & \text { N1a } & \text { M0 } \\ & \text { T2 } & \text { N1a } & \text { M0 } \\ & \text { T3 } & \text { N1a } & \text { M0 } \\ \text { Estádio IV A } & \text { T4a } & \text { N0 } & \text { M0 } \\ & \text { T4a } & \text { N1a } & \text { M0 } \\ & \text { T1 } & \text { N1b } & \text { M0 } \\ & \text { T2 } & \text { N1b } & \text { M0 } \\ & \text { T3 } & \text { N1b } & \text { M0 } \\ \text { Estádio IV B } & \text { T4a } & \text { N1b } & \text { M0 } \\ & \text { T4b } & \text { qualquer N } & \text { M0 } \\ & \text { qualquer T } & \text { qualquer N }\end{array}$




\title{
ANEXO B - Exemplo de ficha de protocolo aplicado a todos os pacientes participantes do estudo
}

\section{CARCINOMA MEDULAR DA TIREÓIDE}

\author{
1. $\mathrm{n}^{\mathrm{o}}$ do caso
}

2. nome

3. $\mathrm{RG}$

4. endereço/telefone

5. idade ao diagnóstico / data nascimento

6. sexo: $\mathrm{M} \quad \mathrm{F}$

7. diagnóstico pré-operatório: $\mathrm{N} \quad \mathrm{S} \quad$ - $\mathrm{PAAF}$

8. diagnóstico pós-operatório: $\mathrm{N} \quad \mathrm{S} \quad-\quad$ congelação

9. nódulo tireóideo palpável parafina

10. adenomegalia palpável

11. sintomas sistêmicos

quais:

12. tireoidectomia - data: total inicial: $\mathrm{S}$ $\mathrm{N}$ - totalização data:

13. esvaziamento cervical: $\mathrm{N}$ S: tipo:

14. $\mathrm{N}^{\mathrm{o}}$ exame antomopatológico

15. maior diâmetro tumor primário $(\mathrm{mm})$ :

16. extensão extracapsular: $\mathrm{S} \quad \mathrm{N}$

17. acometimento tecidos adjacentes: $\mathrm{S} \quad \mathrm{N}$

18. invasões angio-linfáticas ou neurais: $\mathrm{S} \quad \mathrm{N}$

19. multicentricidade: $\mathrm{S} \quad \mathrm{N}$

20. tireopidopatia associada: $\mathrm{N} \quad \mathrm{S}$ qual:

21. HCC: S N

22. amilóide: $\mathrm{S} \quad \mathrm{N}$

23. confirmação IH marcadores:

24. linfonodos positivos: $\mathrm{N}$

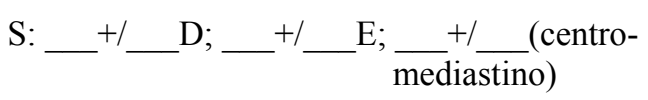

25. extensão neoplásica extranodal: $\mathrm{S}$ 

26. metástases a distância: $\mathrm{N}$
S local:
27. TNM

28. Estádio

29. tipo: Esporádico

Familiar: Isolado _ NEM___ _ doenças associadas:

30. CT (valor paciente/limite normalidade)

pré-operatório - basal:

ob estímulo:

pós-operatório imediato - basal:

sob estímulo:

dosagens seguintes / data:

31. CEA (valor paciente/limite normalidade)

pré-operatório:

pós-operatório imediato:

dosagens seguintes / data:

32. recidiva: $\mathrm{N}$

S diagnóstico: cervical - local:

metástase a distância -local:

ao exame físico

ao exame de imagem - qual:

bioquímica

data: $\quad / \quad$ pós-operatório (meses)

33. tratamento: $\mathrm{N}$

S - reoperação: N
RDT - local:
QT

34. data da última consulta:

35. evolução atual

VSD

VDL

VDM:

MDL

MDM:

perda de seguimento 
ANEXO C - Planilha com especificação de dados clínicos, patológicos e imuno-histoquímicos para cada paciente participante da pesquisa 
9 REFERÊNCIAS BIBLIOGRÁFICAS 


\section{REFERÊNCIAS BIBLIOGRÁFICAS}

1. Saad MF, Ordonez NG, Rashid RK, Guido JJ, Hill CS Jr, Hickey RC, Samaan NA. Medullary carcinoma of the thyroid. A study of the clinical features and prognostic factors in 161 patients. Medicine (Baltimore). 1984; 63:319-42.

2. Hundahl SA, Cady B, Cunningham MP, Mazzaferri E, McKee RF, Rosai J, Shah JP, Fremgen AM, Stewart AK, Hölzer S. Initial results form a prospective cohort study of 5583 cases of thyroid carcinoma treated in the United States during 1996. U.S. and German Thyroid Cancer Study Group. An American College of Surgeons Commission on Cancer Patient Care Evaluation study. Cancer. 2000; 89:202-17.

3. Hundahl SA, Fleming ID, Fremgen AM, Menck HR. A national cancer data base report on 53856 cases of thyroid carcinoma treated in the U.S., 19851995. Cancer. 1998; 83:2639-48.

4. Pacini F, Fontanelli M, Fugazzola L, Elisei R, Romei C, Di Coscio, Miccoli P, Pinchera A. Routine measurement of serum calcitonin in nodular thyroid diseases allows the preoperative diagnosis of unsuspected sporadic medullary thyroid carcinoma. J Clin Endocrinol Metab. 1994; 78:826-9.

5. Bisi H, Fernandes VS, Rosalinda Y, De Camargo A, Longatto Filho A, Ruggeri GB, Abdo AH. Neoplastic and non-neoplastic thyroid lesions in surgical material: historical review of five decades in São Paulo, Brazil. Tumori. 1995; 81:63-6.

6. Bhattacharyya N. A population-based analysis of survival factors in differentiated and medullary thyroid carcinoma. Otolaryngol Head Neck Surg. 2003; 128:115-23.

7. Gilliland FD, Hunt WC, Morris DM, Key CR. Prognostic factors for thyroid carcinoma. A population-based study of 15698 cases from surveillance, epidemiology and end results (SEER) program 1973-1991. Cancer. 1997; 79:564-73.

8. Ezabella MCL. Carcinoma medular da tireóide: análise de 62 casos em seus aspectos clínicos, evolutivos e no diagnóstico e conduta na recidiva [tese]. São Paulo: Faculdade de Medicina da Universidade de São Paulo; 1998.

9. Modigliani E, Cohen R, Campos JM, Conte-Devolx B, Maes B, Boneu A, Schlumberger M, Bigorgne JC, Dumontier P, Leclerc L, Bernard C, Guilhem I (the GETC Study Group). Prognostic factors for survival and for 
biochemical cure in medullary thyroid carcinoma: results in 899 patients. Clin Endocrinol (Oxf). 1998; 48:265-73.

10. Kebebew E, Ituarte PHG, Siperstein AE, Quan-Yang D, Clark OH. Medullary thyroid carcinoma. Clinical characteristics, treatment, prognostic factors, and comparison of staging systems. Cancer. 2000; 88:1139-48.

11. Hyer SL, Vini L, A'Hern R, Harmer C. Medullary thyroid cancer: multivariate analysis of prognostic factors influencing survival. Eur J Surg Oncol. 2000; 26:689-90.

12. Kaserer K, Scheuba C, Neuhold N, Weinhäusel A, Haas O, Vierhapper H, Nierdele B. Sporadic versus familial medullary thyroid microcarcinoma: a histopathologic study of 50 consecutive patients. Am J Surg Pathol. 2001; 25:1245-51.

13. Cohen R, Campos JM, Salaün C, Heshmati HM, Kraimps JL, Proye C, Sarfati E, Henry JF, Niccoli-Sire P, Modigliani E, and Groupe D'Étude Des Tumeurs À Calcitonine (GETC). Preoperative calcitonin levels are predictive of tumor size and postoperative calcitonin normalization in medullary thyroid carcinoma. J Clin Endocrinol Metab. 2000; 85:919-22.

14. Guyetant S, Josselin N, Savagner F, Rohmer V, Michalak S, Saint-Andre JP. C-cell hyperplasia and medullary thyroid carcinoma: clinic pathological and genetic correlations in 66 consecutive patients. Mod Pathol. 2003; 16:756-63.

15. Pellegriti G, Leboulleux S, Baudin E, Bellon N, Scollo C, Travagli JP, Schlumberger M. Long-term outcome of medullary thyroid carcinoma in patients with normal postoperative medical imaging. Br J Cancer. 2003; 88:1537-42.

16. Ukkat J, Gimm O, Brauckhoff M, Bilkenroth U, Dralle H. Single center experience in primary surgery for medullary thyroid carcinoma. World $\mathrm{J}$ Surg. 2004; 28:1271-4.

17. Kameyama K, Takami H. Medullary thyroid carcinoma: nationwide Japanese survey of 634 cases in 1996 and 271 cases in 2002. Endocr J. 2004; 51:453-6.

18. Horn NC. Carcinoma of the thyroid. Description of a distinctive morphological variant and report of 7 cases. Cancer. 1951; 4:697-707.

19. Hazard JB, Hawk WA, Crile G. Medullary (solid) carcinoma of the thyroid a clinicopathologic entity. J Clin Endocrinol Metab. 1959; 19:152-61.

20. Schimke RN, Hartmann WH. Familial amyloid-producing medullary thyroid carcinoma and pheocromocytoma. A distinct genetic entity. Ann Intern Med. $1965 ; 63: 1027-39$. 
21. Sipple JH. The association of pheocromocytoma with carcinoma of the thyroid gland. Amer J Med. 1961; 31:1027-39.

22. Willians ED. Histogenesis of medullary carcinoma of the thyroid. J Cin Pathol. 1966; 19:114-8.

23. Steiner AL, Goodman AD, Powers SR. Study of kindred with pheocromocytoma, medullary thyroid carcinoma, hyperparathyroidism and Cushing's disease: multiple endocrine neoplasia type 2. Medicine (Baltimore). 1968; 47:371-409.

24. Tashjian AH Jr, Melvin EW. Medullary carcinoma of the thyroid gland. Studies of thyrocalcitonin in plasma and tumor extracts. N Engl J Med. 1968; 279:279-83.

25. Simpson NE, Kidd KK, Goodfellow PJ, McDermid H, Myers S, Kidd KK Jr, Jackson CE, Duncan AM, Farrer LA, Brasch K. Assignment of multiple endocrine neoplasia type 2A to chromosome 10 by linkage. Nature. 1987; 328:528-30.

26. Mathew CG, Chin KS, Easton DF, Thorpe K, Carter C, Liou GI, Fong SL, Bridges $\mathrm{CD}$, Haak H, Kruseman AC. A linked genetic marker for multiple endocrine neoplasia type 2A on chromosome 10. Nature. 1987; 328:527-8.

27. Mulligan LM, Kwok JB, Healey CS, Elsdon MJ, Eng C, Gardner E, Love DR, Mole SE, Moore JK, Papi L. Ponder MA, Telenius H, Tunnacliffe A, Ponde BAJ. Germ-line mutations of the RET proto-oncogene in multiple endocrine neoplasia type 2A. Nature. 1993; 363:458-60.

28. Donis-Keller H, Dou S, Chi D, Carlson KM, Toshima K, Laimore TC, Howe JR, Moley JF, Goodfellow P, Wells SA Jr. Mutations in the RET protooncogene are associated with MEN2A and FMTC. Hum Mol Genet. 1993; 2:851-6.

29. Hofstra RMW, Landsvater RM, Ceccherini I, Stulp RP, Stelwagen T, Luo Y, Pasini B, Hoppener JWM, Van Amstel HKP, Romeo G, Lips CJM, Buys CHCM. A mutation in the RET proto-oncogene associated with multiple endocrine neoplasia type $2 \mathrm{~B}$ and sporadic medullary thyroid carcinoma. Nature. 1994; 367:375-6.

30. Mulligan LM, Eng C, Healey CS, Clayton D, Kwok JBJ, Gardner E, Ponder MA, Frilling A, Jackson CE, Lehnert H, Neumann HPH, Thibodeau SN, Ponder BAJ. Specific mutations of the RET proto-oncogene are related to disease phenotype in MEN 2A and FMTC. Nature Genet. 1994; 6:70-4.

31. Frank-Raue K, Hoppner W, Frilling A, Kotzerke J, Dralle H, Haase R, Mann K, Seif F, Kirchner R, Rendl J, Deckart HF, Ritter MM, Hampel R, Klempa J, 
Scholz GH, Raue F. Mutations of the ret proto-oncogene in German multiple endocrine neoplasia families: relation between genotype and phenotaype. German Medullary Thyroid Carcinoma Study Group. J Clin Endocrinol Metab. 1996; 81:1780-3.

32. Eng C, Clayton D, Schuffenecker I, Lenoir G, Cote G, Gagel RF, Van Amstel HK, Lips CJ, Nishisho I, Takai SI, Marsh DJ, Robinson BG, Frank-Raue K, Raue F, Xue F, Noll WW, Romei C, Pacini F, Fink M, Nierdele B, Zedenius J, Nordenskjold M, Komminoth P, Hendy GN, Mulligan LM. The relationship between specific RET proto-oncogene mutations and disease phenotype in multiple endocrine neoplasia type 2. International RET mutation consortium analysis. JAMA. 1996; 276:1575-9.

33. Machens A, Niccoli-Sire P, Hoegel J, Frank-Raue K, Van Vroonhover TJ, Roeher HD, Wahl RA, Lamesch P, Raue F, Conte-Devolx B, Dralle H (EUROMEN study group). Early malignant progression of hereditary medullary thyroid cancer. N Engl J Med. 2003; 349:1517-25.

34. Machens A, Ukkat J, Brauckhoff M, Gimm O, Dralle H. Advances in the management of hereditary medullary thyroid cancer. J Intern Med. 2005; 257:50-9.

35. Randolph GW, Maniar D. Medullary carcinoma of the thyroid. Cancer Control. 2000; 7:253-61.

36. Kraiem Z, Korem S. Matrix metalloproteinases and the thyroid. Thyroid. 2000; 10:1061-9.

37. Cvejić D, Savin S, Paunovic I, Tatic S, Havelka M. Immunohistochemical localization of matrix metalloproteinase-2 (MMP-2) in medullary thyroid carcinoma. Arch Oncol. 2000; 8:95-7.

38. Yoon SO, Park SJ, Yun CH, Chung AS. Roles of matrix metalloproteinases in tumor metastasis and angiogenesis. J Biochem Mol Biol. 2003; 36:128-37.

39. Raza SL, Cornelius LA. Matrix metalloproteinases: pro- and anti-angiogenic activities. J Investig Dermatol Symp Proc. 2000; 5:47-54.

40. Vihinen P, Kähäri VM. Matrix metalloproteinases in cancer: prognostic markers and therapeutic targets. Int J Cancer. 2002; 99:157-66.

41. Kim DS, McCabe CJ, Buchanan MA, Watkinson JC. Oncogenes in thyroid cancer. Clin Otolaryngol. 2003; 28:386-395.

42. Knudson AG Jr, Strong LC, Anderson DE. Hereditary and cancer in man. Prog Med Genet. 1973; 9:113-58. 
43. Brandi ML, Gagel RF, Angeli A, Bilezikian JP, Beck-Peccoz P, Bordi C, Conte-Devolx B, Falchetti A, Gheri RG, Libroia A, Lips CJM, Lombardi G, Mannelli M, Pacini F, Ponder BAJ, Raue F, Skogseid B, Tamburrano G, Thakker RV, Thompson NW, Tomassetti P, Tonelli F, Wells SA Jr, Marx SJ. Consensus. Guidelines for diagnosis and therapy of MEN type 1 and type 2. J Clin Endocrinol Metab. 2001; 86:5658-71.

44. Hoff AO, Cote GH, Gagel RF. Multiple endocrine neoplasias. Annu Rev Physiol. 2000; 62:377-411.

45. Kim LT, Fleming JB, Lopez-Guzman C, Nwariaku F. Focal adhesions and associated proteins in medullary thyroid carcinoma cells. J Surg Res. 2003; 111:177-84.

46. Machens A, Hans-Jürgen H, Phuong NT, Dralle H. Malignant progression from C-cell hyperplasia to medullary thyroid carcinoma in 167 carriers of RET germline mutations. Surgery. 2003; 134:425-431.

47. Dralle H, Gimm O, Simon D, Frank-Raue K, Görtz G, Niederle B, Wahl RA, Koch B, Walgenbach S, Hampel R, Ritter MM, Spelsberg F, Heiss A, Hinze R, Höppner W. Prophylactic thyroidectomy in 75 children and adolescents with hereditary medullary thyroid carcinoma: German and Austrian experience. World J Surg. 1998; 22:744-51.

48. Szinnai G, Meier C, Komminoth P, Zumteg UW. Review of multiple endocrine neoplasia type $2 \mathrm{~A}$ in children: therapeutic results of early thyroidectomy and prognostic value of codon analysis. Pediatrics. 2003; 111:132-9.

49. Gimm O, Marsh DJ, Andrew SD, Frilling A, Dahia PLM, Mulligan LM, Zajac JD, Robinson BG, Eng C. Germline dinucleotide mutation in codon 883 of the ret proto-oncogene in multiple endocrine neoplasia type 2B without codon 918 mutation. J Clin Endocrinol Metab. 1997; 82:3902-4.

50. Jindrichova S, Kodet R, Krskova L, Vlcek P, Bendlova B. The newly detected mutations in the RET proto-oncogene in exon 16 as a cause of sporadic medullary thyroid carcinoma. J Mol Med. 2003; 81:819-23.

51. Schilling T, Bürck J, Hans-Peter S, Clemens A, Otto HF, Höppner W, Herfarth C, Ziegler R, Schwab M, Raue F. Prognostic value of codon 918 (ATG-ACG) RET proto-oncogene mutation in sporadic medullary thyroid carcinoma. Int J Cancer. 2001; 95:62-6.

52. Elisei R, Cosci B, Romei C, Bottici V, Sculli M, Lari R, Barale R, Pacini F, Pinchera A. RET exon 11 (G691S) polymorphism is significantly more frequent in sporadic medullary thyroid carcinoma than in the general population. J Clin Endocrinol Metab. 2004; 89:3579-84. 
53. Rosai J, Carangiu ML, De Lellis RA. Atlas of Tumor Pathology: tumors of the thyroid gland. Third Series. Washington, DC: Armed Forces Institute of Pathology, 1992.

54. Guyetant S, Wion-Barbot N, Rousselet MC, Franc B, Bigorgne JC, Saint André JP. C-cell hyperplasia associated with chronic lymphocytic thyroiditis: a retrospective quantitative study of 112 cases. Hum Pathol. 1994; 25:514-21.

55. Engelbach M, Heerdt S, Görges R, Kunt T, Pfützner A, Forst T, Diefenbach $\mathrm{K}$, Walgenbach $\mathrm{S}$, Beyer $\mathrm{J}$. Is there an ectopic secretion of monometric calcitonin in human beings? Lengenbecks Arch Surg. 1998; 383:456-9.

56. Girelli ME, Dotto S, Nacamulli D, Piccolo M, De Vido D, Russo T, Bernante P, Pelizzo MR, Busnardo B. Prognostic value of early postoperative calcitonin level in medullary thyroid carcinoma. Tumori.1994; 80:113-7.

57. Franc S, Niccoli-Sire P, Cohen R, Bardet S, Maes B, Murat A, Krivitzky A, Modigliani E and the GETC. Complete surgical lymph node resection does not prevent authentic recurrences of medullary carcinoma. Clin Endocrinol (Oxf). 2001; 55:403-9.

58. Scheuba C, Kaserer K, Weinhäusl A, Pandev R, Kaider A, Passler C, Prager G, Vierhapper H, Haas OA, Niederle B. Is medullary thyroid cancer predictable? A prospective study of 86 patients with abnormal pentagastrin tests. Surgery. 1999; 126:1089-96.

59. Hotz HG, Runkel NS, Frank-Raue K, Raue F, Buhr HJ. Prophylactic thyroidectomy in MEN IIA: does the calcitonin level correlate with tumor spread? Langenbecks Arch Surg. 1998; 383:170-3.

60. Saad MF, Fritsche HA Jr, Samaan NA. Diagnostic and prognostic values of carcinoembryonic antigen in medullary carcinoma of the thyroid. J Clin Endocrinol Metab. 1984; 58:889-94.

61. Rosai J. Immunohistochemical markers of thyroid tumors significance and diagnostic applications. Tumori. 2003; 89:517-9.

62. Miyauchi A, Matsuzuka F, Hirai K, Yokozawa T, Kobayashi K, Ito Yasuhiro, Nakano K, Kuma K, Futami H, Yamaguchi K. Prospective trial of unilateral surgery for nonhereditary medullary thyroid carcinoma in patients without germline RET mutations. World J Surg. 2002; 26:1023-8.

63. Cohen MS, Moley JF. Surgical treatment of medullary thyroid carcinoma. J Intern Med. 2003; 253:616-26.

64. Brauckhoff M, Gimm O, Weiss CL, Ukkat J, Sekulla C, Brauckhoff K, Phuong NT, Dralle H. Multiple endocrine neoplasia 2B syndrome due to 
codon 918 mutation: clinical manifestation and course in early and late onset disease. World J Surg. 2004; 28:1305-11.

65. Jimenez C, Dang GT, Schultz P, El-Naggar A, Shapiro S, Barnes EA, Evans DB, Vassilopoulou-Sellin R, Gagel RF, Cote GJ, Hoff AO. A novel point mutation of the RET proto-oncogene involving the second intracellular tyrosine kinase domain in a family with medullary thyroid carcinoma. J Clin Endocrinol Metab. 2004; 89:3521-6.

66. Gimm O, Ukkat J, Niederle BE, Weber T, Phuong NT, Brauckhoff M, Niederle B, Dralle H. Timing and extent of surgery in patients with familial medullary thyroid carcinoma/multiple endocrine neoplasia $2 \mathrm{~A}$ - related RET mutations not affecting codon 634. World J Surg. 2004; 28:1312-6.

67. Tisell LE, Hansson G, Jansson S. Surgical treatment of medullary carcinoma of the thyroid. Horm Metab Res Suppl. 1989; 21:29-31.

68. Moley JF, DeBenedetti MK. Patterns of nodal metastases in palpable medullary thyroid carcinoma - recommendations for extent of node dissection. Ann Surg. 1999; 229:880-8.

69. Tavares MR. Distribuição das metástases em linfonodos cervicais no carcinoma medular da tireóide [tese livre-docência]. São Paulo: Faculdade de Medicina da Universidade de São Paulo; 2003.

70. Yen TW, Shapiro SE, Gagel RF, Sherman SI, Lee EL, Evans DB. Medullary thyroid carcinoma: results of a standardized surgical approach in a contemporary series of 80 consecutive patients. Surgery. 2003; 134:890-9.

71. Greene FL, Page DL, Fleming ID, Fritz AG, Balch CM, Haller DG, Morrow M. AJCC - Manual de Estadiamento do Câncer. Tradução de Daniela Dornelles Rosa. 6ª ed. Porto Alegre: Artmed Editora; 2004. 93-103.

72. Sobin LH, Wittekind Ch. TNM Classificação dos Tumores Malignos. Tradução de Maria Inez P. Gadelha. 5aed. Rio de Janeiro: Ministério da Saúde, Secretaria de Assistência à Saúde e Instituto Nacional do Câncer; 1998. 51-5.

73. Henry JF, Denizot A, Puccini M, Gramatica L, Kvachenyuk A, Conte-Devolx B, De Micco C. Latent subclinical medullary thyroid carcinoma: diagnosis and treatment. World J Surg. 1998; 22:752-7.

74. Elisei R, Bottici V, Luchetti F, Di Coscio G, Romei C, Grasso L, Miccoli P, Iacconi P, Basolo F, Pinchera A, Pacini F. Impact of routine measurement of serum calcitonin on the diagnosis and outcome of medullary thyroid cancer: experience in 10864 patients with nodular thyroid disorders. J Clin Endocrinol Metab. 2004; 89:163-8. 
75. Ledger GA, Khosla S, Lindor NM, Thibodeau SN, Gharib H. Genetic testing in the diagnosis and management of multiple endocrine neoplasia type II. Ann Intern Med. 1995; 122:118-24.

76. Drosten M, Pützer BM. Gene therapeutic approaches for medullary thyroid carcinoma treatment. J Mol Med. 2003; 81:411-9.

77. Ellenhorn JDI, Shah JP, Brennan M. Impact of therapeutic regional lymph node dissection for medullary carcinoma of the thyroid gland. Surgery. 1993; 114:1078-81.

78. Dralle H, Damm I, Scheumann GF, Kotzerke J, Kupsch E. Frequency and significance of cervicomediastinal lymph node metastases in medullary thyroid carcinoma: results of a compartment-oriented microdissection method. Henry Ford Hosp Med J. 1992; 40:264-7.

79. Dralle H, Damm I, Scheumann GF, Kotzerke J, Kupsch E, Geerlings H, Pichlmayr R. Compartment-oriented microdissection of regional lymph nodes in medullary thyroid carcinoma. Surg Today. 1994; 24:112-21.

80. Kaczirek K, Schindl M, Weinhäusel A, Cheuba C, Passler C, Prager G, Raderer M, Hamilton G, Mittlböck M, Siegl V, Pfragner R, Niederle B. Cytotoxic activity of camptothecin and paclitaxel in newly established continuous human medullary thyroid carcinoma cell lines. J Clin Endocrinol Metab. 2004; 89:2397-401.

81. Castellani MR, Alessi A, Savelli G, Bombardieri E. The role of radionuclide therapy in medullary thyroid cancer. Tumori. 2003; 89:560-2.

82. Bell CD, Vidal S, Kovacs K, Horvath E, Rotondo F. An immunohistochemical survey of nine cases of medullary carcinoma of thyroid including reactivity for Cox-1 and Cox-2 enzymes. Endocr Pathol. 2002; 13:331-40.

83. Quidville V, Segond N, Pidoux E, Cohen R, Jullienne A, Lausson S. Tumor growth inhibition by indomethacin in a mouse model of human medullary thyroid cancer: implication of cyclooxygenases and 15-hydroxyprostaglandin dehydrogenase. Endocrinology. 2004; 145:2561-71.

84. Cohen MS, Hussain HB, Moley JF. Inhibition of medullary thyroid carcinoma cell proliferation and RET phosphorylation by tyrosine kinase inhibitors. Surgery. 2001; 132:960-6.

85. Liu Z, Falola J, Zhu X, Gu Y, Kim L, Sarosi GA, Anthony T, Nwariaku F. Antiproliferative effects of Src inhibition on medullary thyroid cancer. J Clin Endocrinol Metab. 2004; 89:3503-9. 
86. Stift A, Sachet M, Yagubian R, Bittermann C, Dubsky O, Brostjan C, Pfragner R, Niederle B, Jakewsz R, Gnant M, Friedl J. Dendritic cell vaccination in medullary thyroid carcinoma. Clin Cancer Res. 2004; 1:294453.

87. Maio M, Coral S, Sigalotti L, Elisei R, Romei C, Rossi G, Cortini E, Colizzi F, Fenzi G, Altomonte M, Pinchera A, Vitale M. Analysis of cancer/testis antigens in sporadic medullary thyroid carcinoma: expression and humoral response to NY-ESO-1. J Clin Endocrinol Metab. 2003; 88:748-54.

88. Gimm O, Ukkat J, Dralle H. Determinative factors of biochemical cure after primary and reoperative surgery for sporadic medullary thyroid carcinoma. World J Surg. 1998; 22:562-8.

89. Dralle H, Sheumann GFW, Proye C, Bacourt F, Frilling A, Limbert F, Gheri G, Henry JF, Berner M, Niederle B, Vasen HFA. The value of lymph node dissection in hereditary medullary thyroid carcinoma: a retrospective, European, multicentre study. J Intern Med. 1995; 238:357-61.

90. Van Heerden JA, Grant CS, Gharib H, Hay ID, Ilstrup DM. Long-term course of patients with persistent hypercalcitoninemia after apparent curative primary surgery for medullary thyroid carcinoma. Ann Surg. 1990; 212:395400.

91. Bustillo A, Telischi F, Weed D, Civantos F, Angeli S, Serafini A, Whiteman M. Octreotide scintigraphy in the head and neck. Laryngoscope. 2004; 114:434-40.

92. Behr TM, Gratz S, Markus PM, Dunn RM, Hüfner M, Schauer A, Fischer M, Munz DL, Becker H, Becker W. Anti-carcinoembryonic antigen antibodies versus somatostatin analogs in the detection of metastatic medullary thyroid carcinoma. Cancer. 1997; 80:2436-57.

93. Gotthardt M, Battmann A, Hoffken H, Schurrat T, Pollum H, Beuter D, Gratz S, Behe M, Bauhofer A, Klose KJ, Behr TM. 18F-FDG PET, somatostatin receptor scintigraphy, and $\mathrm{CT}$ in metastatic medullary thyroid carcinoma: a clinical study and an analysis of the literature. Nucl Med Commun. 2004; 25:439-43.

94. Weber T, Schilling T, Frank-Raue K, Colombo-Benkmann M, Hinz U, Ziegler R, Klar E. Impact of modified radical neck dissection on biochemical cure in medullary thyroid carcinomas. Surgery. 2001; 130:1044-9.

95. Scopsi L, Sampietro G, Boracchi P, Del Bo R, Gullo M, Placucci M, Pilotti S. Multivariate analysis of prognostic factors in sporadic medullary carcinoma of the thyroid. A retrospective study of 109 consecutive patients. Cancer. 1996; 78:2173-83. 
96. Sheikh HA, Tometsko M, Niehouse L, Aldeeb D, Swalsky P, Finkelstein S, Barnes EL, Hunt JL. Molecular genotyping of medullary thyroid carcinoma can predict tumor recurrence. Am J Surg Pathol. 2004; 28:101-6.

97. Roncalli M, Viale G, Grimelius L, Johansson H, Wilander E, Alfano RM, Springall D, Battezzati PM, Polak JM, Coggi G. Prognostic value of N-myc immunoreactivity in medullary thyroid carcinoma. Cancer. 1994; 74:134-41.

98. Mustafa T, Klonisch T, Hombach-Klonisch S, Kehlen A, Schmutzler C, Koehrle J, Gimm O, Dralle H, Hoang-Vu C. Expression of CD97 and CD55 in human medullary thyroid carcinomas. Int J Oncol. 2004; 24:285-94.

99. Tisell LE, Oden A, Altiparmak G, Mõlne J, Ahlman H, Nilsson O. The Ki67 "index" a prognostic marker in medullary thyroid carcinoma. Br J Cancer. 2003; 89:2093-7.

100. Ensinger C, Prommegger R, Kendler D, Gabriel M, Spizzo G, Mikuz G, Kremser R. Her2/neu expression in C cell hyperplasia and medullary thyroid carcinomas. Anticancer Res. 2003; 23:2241-3.

101. Seiki M. Membrane-type 1 matrix metalloproteinase: a key enzyme for tumor invasion. Cancer Lett. 2003; 194:1-11.

102. Nabeshima K, Inoue T, Shimao Y, Sameshima T. Matrix metalloproteinases in tumor invasion: role for cell migration. Pathol Int. 2002; 54:255-64.

103. Djonov V, Högger K, Sedlacek R, Laissue J, Draeger A. MMP-19: cellular localization of a novel metalloproteinase within normal breast tissue and mammary gland tumors. J Pathol. 2001; 195:147-55.

104. Murray GI. Matrix metalloproteinases: a multifunctional group of molecules. J Pathol. 2001; 195:135-7.

105. Woodhouse EC, Chuaqui RF, Liotta LA. General mechanisms of metastasis. Cancer. 1997; 80:1529-37.

106. Brooks PC, Stromblad S, Sanders LC, von Schalscha TL, Aimes RT, StetlerStevenson WG, Quigley JP, Cheresh DA. Localization of matrix metalloproteinase MMP-2 to the surface of invasive cells by interaction with integrin alpha v beta 3. Cell. 1996; 85:683-93.

107. Ramsden JD. Angionenesis in the thyroid gland. J Endocrinol. 2000; 166:475-80.

108. Mannello F, Luchetti F, Falcieri E, Papa S. Multiple roles of matrix metalloproteinases during apoptosis. Apoptosis. 2005; 10:19-24. 
109. Hinze R, Gimm O, Taubert H, Bauer G, Dralle H, Holzhausen HJ, Rath FW. Regulation of proliferation and apoptosis in sporadic and hereditary medullary carcinomas and their putative precursor lesions. Virchows Arch. 2000; 437:256-63.

110. Basolo F, Pollina L, Fontanini G, Fiore L, Pacini F, Baldanzi A. Apoptosis and proliferation in thyroid carcinoma: correlation with bcl-2 and p-53 protein expression. Br J Cancer. 1997; 75: 537-41.

111. Takahashi C, Sheng Z, Horan TP, Kitayama H, Maki M, Hitomi K, Kitaura Y, Takai S, Sasahara R, Horimoto A, Ikawa Y, Ratzkin BJ, Arakawa T, Noda $\mathrm{M}$. Regulation of matrix metalloproteinase- 9 and inhibition of tumor invasion by the membrane-anchored glycoprotein RECK. Proc Natl Acad Sci USA. 1998; 95:13221-6.

112. Oh J, Takahashi R, Kondo S, Mizoguchi A, Adachi E, Sashara RM, Nishimura S, Iamamura Y, Kitayama H, Alexander DB, Ide C, Horan TP, Arakawa T, Yoshida H, Nishikawa S, Itoh Y, Seiki M, Itohara S, Takahashi $\mathrm{C}$, Noda M. The membrane-anchored MMP inhibitor RECK is a key regulator of extracellular matrix integrity and angiogenesis. Cell. 2001; 107:789-800.

113. Shamamian P, Schwartz JD, Pocock BJZ, Monea S, Whiting D, Marcus SG, Mignatti P. Activation of progelatinase A (MMP-2) by neutrophil elastase, cathepsin $\mathrm{G}$, and proteinase-3: a role for inflammatory cells in tumor invasion and angiogenesis. J Cell Physiol. 2001; 189:197-206.

114. Nakopoulou L, Tsirmpa I, Alexandrou P, Louvrou A, Ampela C, Markaki S, Davaris PS. MMP-2 protein in invasive breast cancer and the impact of MMP-2/TIMP-2 phenotype on overall survival. Breast Cancer Res Treat. $2003 ; 77: 145-55$.

115. Davies B, Miles DW, Happerfield LC, Naylor MS, Bobrow LG, Rubens RD, Balkwill FR. Activity of type IV collagenases in benign and malignant breast disease. Br J Cancer. 1993; 67:1126-31.

116. Davidson B, Goldberg I, Kopolovic J, Lerner-Geva L, Gotlieb WH, BenBaruch G, Reich R. MMP-2 and TIMP-2 expression correlates with poor prognosis in cervical carcinoma - a clinicopathologic study using immunohistochemistry and mRNA in situ hybridization. Gynecol Oncol. $1999 ; 73: 372-82$.

117. Chan CC, Menges M, Orzechowski HD, Orendain N, Pistorius G, Feifel G, Zeitz M, Stallmach A. Increased matrix metalloproteinase 2 concentration and transcript expression in advanced colorectal carcinomas. Int J Colorectal Dis. 2001; 16:133-40. 
118. Yoshizaki T, Maruyama Y, Sato H, Furukawa M. Expression of tissue inhibitor of matrix metalloproteinase-2 correlates with activation of matrix metalloproteinase-2 and predicts poor prognosis in tongue squamous cell carcinoma. Int J Cancer. 2001; 95:44-50.

119. Okada A, Bellocq JP, Rouyer N, Chenard MP, Rio MC, Chambon P, Basset P. Membrane-type matrix metalloproteinase (MT-MMP) gene is expressed in stromal cells of human colon, breast, and head and neck carcinomas. Proc Natl Acad Sci USA. 1995; 92:2730-4.

120. Kayano K, Shimada T, Shinomiya T, Nakai S, Hisa Y, Aoki T, Seiki M, Okada Y. Activation of pro-MMP mediated by MT1-MMP in human salivary gland carcinomas: possible regulation of pro-MMP-2 activation by TIMP-2. J Pathol. 2004; 202:403-11.

121. Maeta H, Ohgi S, Terada T. Protein expression of matrix metalloproteinases 2 and 9 and tissue inhibitors of metalloproteinase 1 and 2 in papillary thyroid carcinomas. Virchows Arch. 2001; 438:121-8.

122. Lin SY, Wang YY, Sheu WHH. Preoperative plasma concentrations of vascular endothelial growth factor and matrix metalloproteinase 9 are associated with stage progression in papillary thyroid cancer. Clin Endocrinol (Oxf). 2003; 58:513-8.

123. Nakamura H, Ueno H, Yamashita K, Shimada T, Yamamoto E, Noguchi M, Fujimoto N, Sato H, Seiki M, Okada Y. Enhanced production and activation of progelatinase A mediated by membrane-type 1 matrix metalloproteinase in human papillary thyroid carcinomas. Cancer Res. 1999; 59:467-73.

124. Zedenius J, Ståhle-Bäckdahl M, Enberg U, Grimelius L, Larsson C, Wallin G, Bäckdahl M. Stromal fibroblasts adjacent to invasive thyroid tumors: expression of gelatinase A but not stromelysin 3 mRNA. World J Surg. 1996; 20:101-6.

125. Tomita T. Matrix metalloproteinases and tissue inhibitors of metalloproteinases in thyroid C-cells and medullary thyroid carcinomas. Histopathology. 1997; 31:150-6.

126. Campo E, Merino MJ, Liotta L, Neumann R, Stetler-Stevenson W. Distribution of the 72-kd type IV collagenase in nonneoplastic and neoplastic thyroid tissue. Hum Pathol. 1992; 23:1395-401.

127. Kameyama K. Expression of MMP-1 in the capsule of thyroid cancer relationship with invasiveness. Path Res Pract. 1996; 192:20-6.

128. Korem S, Resnick MB, Kraiem Z. Similar and divergent patterns in the regulation of matrix metalloproteinase-1 (MMP-1) and tissue inhibitor of 
MMP-1 gene expression in benign and malignant human thyroid cells. J Clin Endocrinol Metab. 1999; 84:3322-7.

129. Friguglietti CUM, Mello ES, Castro IV, Silva Filho GB, Alves VAF. Metalloproteinase-9 immunoexpression and angiogenesis in thyroid follicular neoplasms: relation to clinical and histopathologic features. Head Neck. 2000; 22:373-9.

130. Dahlman T, Lammerts E, Wik M, Bergström D, Grimelius L, Westermark K, Rubin K, Heldin NE. Fibrosis in undifferentiated (anaplastic) thyroid carcinomas: evidence for a dual action of tumor cells in collagen type I synthesis. J Pathol. 2000; 191:376-86.

131. Korem S, Kraiem Z, Shiloni E, Yehezkel O, Sadeh O, Resnick MB. Increased expression of matrix metalloproteinase-2: a diagnostic marker but not prognostic marker of papillary thyroid carcinoma. Isr Med Assoc J. 2002; $4: 247-51$.

132. Sivula A, Talvensaari-Mattila A, Lundin J, Joensuu H, Haglung C, Ristimaki A, Turpeenniemi-Hujanen T. Association of cyclooxygenase-2 and matrix metalloproteinase-2 expression in human breast cancer. Breast Cancer Res Treat. 2005; 89:215-20.

133. Jones JL, Glynn P, Walker RA. Expression of MMP-2 and MMP-9, their inhibitors, and the activator MT1-MMP in primary breast carcinomas. J Pathol. 1999; 189:161-8.

134. Remacle A, McCarthy K, Noel A, Maguire T, McDermott E, O'Higgins N, Foidart JM, Duffy MJ. High levels of TIMP-2 correlate with adverse prognosis in breast cancer. Int J Cancer. 2000; 89:118-21.

135. Nielsen BS, Rank F, López JM, Balbin M, Vizoso F, Lund LF, Danø K, López-Otín C. Collagenase-3 expression in breast myofibroblasts as a molecular marker of transition of ductal carcinoma in situ lesions to invasive ductal carcinomas. Cancer Res. 2001; 61:7091-100.

136. Kurahara S, Shinohara M, Ikebe T, Nakamura S, Beppu M, Hiraki A, Takeuchi H, Shirasuna K. Expression of MMPs, MT-MMP, and TIMPs in squamous cell carcinoma of the oral cavity: correlations with tumor invasion and metastasis. Head Neck. 1999; 21:627-38.

137. O-Charoenrat P, Rhys-Evans PH, Eccles SA. Expression of matrix metalloproteinases and their inhibitors correlates with invasion and metastasis in squamous cell carcinoma of the head and neck. Arch Otolaryngol Head Neck Surg. 2001; 127:813-20. 
138. de Vicente JC, Fresno MF, Villalain L, Vega JA, Hernandez Vallejo G. Expression and clinical significance of matrix metalloproteinase-2 and matrix metalloproteinase-9 in oral squamous cell carcinoma. Oral Oncol. 2005; 41:283-93.

139. Culhaci N, Metin K, Copcu E, Dikicioglu E. Elevated expression of MMP-13 and TIMP-1 in head and neck squamous cell carcinomas may reflet increased tumor invasiveness. BMC Cancer. 2004; 4:42.

140. Ondruschka C, Buhtz P, Motsch C, Freigang B, Scneider-Stock R, Roessner A, Boltze C. Prognostic value of MMP-2, -9 and TIMP-1, -2 immunoreactive protein at the invasive front in advanced head and neck squamous cell carcinomas. Pathol Res Pract. 2002; 198:509-15.

141. Ylisirnio S, Hoyhtya M, Turpeenniemi-Hujanen T. Serum metalloproteinases $-2,-9$ and tissue inhibitors of metalloproteinases $-1,-2$ in lung cancer. Anticancer Res. 2000; 20:1311-6.

142. Zhou Y, Yu C, Miao X, Wang Y, Tan W, Sun T, Zhang X, Xiong P, Lin D. Functional haplotypes in the promoter of matrix metalloproteinase-2 and lung cancer susceptibility. Carcinogenesis. 2005; 26:1117-21.

143. Hofmann UB, Westphal JR, Waas ET, Zendman AJ, Cornelissen IM, Ruiter DJ, van Muijen GN. Matrix metalloproteinases in human melanoma cell lines and xenografts: increased expression of activated matrix metalloproteinase-2 (MMP-2) correlates with melanoma progression. Br J Cancer. 1999; 81:77482.

144. Kuittinen O, Savolainen ER, Koistinen P, Möttönen M, TurpeenniemiHujanen T. MMP-2 and MMP-9 expression in adult and childhood acute lymphatic leukemia (ALL). Leuk Res. 2001; 25:125-31.

145. Kuittinen O, Savolainen ER, Koistinen P, Turpeenniemi-Hujanen $\mathrm{T}$. Gelatinase A and B (MMP-2, MMP-9) in leukaemia. MMP-2 may indicate a good prognosis in AML. Anticancer Res. 1999; 19:4395-400.

146. Zhang S, Li L, Lin JY, Lin H. Imbalance between expression of matrix metalloproteinase-9 and tissue inhibitor of metalloproteinase-1 in invasiveness and metastasis of human gastric carcinoma. World $\mathrm{J}$ Gastroenterol. 2003; 9:899-904.

147. Takeuchi T, Hisanaga M, Nagao M, Ikeda N, Fujii H, Koyama F, Mukogawa T, Matsumoto H, Kondo S, Takahashi C, Noda M, Nakajima Y. The membrane-anchored matrix metalloproteinase (MMP) regulator RECK in combination with MMP-9 serves as an informative prognostic indicator for colorectal cancer. Clin Cancer Res. 2004; 10:5572-9. 
148. Matsuyama Y, Takao S, Aikou T. Comparison of matrix metalloproteinase expression between primary tumors with or without liver metastasis in pancreatic and colorectal carcinomas. J Surg Oncol. 2002; 80:105-10.

149. Di Nezza LA, Misajon A, Zhang J, Jobling T, Quinn MA, Ostor AG, Nie G, Lopata A, Salamonsen LA. Presence of active gelatinases in endometrial carcinoma and correlation of matrix metalloproteinase expression with increasing tumor grade and invasion. Cancer. 2002; 94:1466-75.

150. Davidson B, Goldberg I, Gotlieb WH, Kopolovic J, Ben-Baruch G, Nesland JM, Berner A, Bryne M, Reich R. High levels of MMP-2, MMP-9, MT1MMP and TIMP-2 mRNA correlate with poor survival in ovarian carcinoma. Clin Exp Metastasis. 1999; 17:799-808.

151. Davidson B, Goldberg I, Gotlieb WH, Kopolovic J, Ben-Baruch G, Nesland $\mathrm{JM}$, Reich R. The prognostic value of metalloproteinases and angiogenic factors in ovarian carcinoma. Mol Cell Endocrinol. 2002; 187:39-45.

152. Fan YZ, Zhang JT, Yang HC, Yang YQ. Expression of MMP-2, TIMP-2 protein and the ratio of MMP-2/TIMP-2 in gallbladder carcinoma and their significamce. World J Gastroenterol. 2002; 8:1138-43.

153. Myata Y, Kanda S, Nomata K, Hayashida Y, Kanetake H. Expression of metalloproteinase-2, metalloproteinase-9, and tissue inhibitor of metalloproteinase- 1 in transicional cell carcinoma of upper urinary tract: correlation with tumor stage and survival. Urology. 2004; 63:602-8.

154. Kawamura K, Kamiya N, Suyama T, Shimbo M, Oosumi N, Suzuki H, Ueda $\mathrm{T}$, Tobe $\mathrm{T}$, Igarashi $\mathrm{T}$, Ito $\mathrm{H}$, Ishikura $\mathrm{H}$. In situ gelatinolytic activity correlates with tumor progression and prognosis in patients with bladder cancer. J Urol. 2004; 172:1480-4.

155. Pinheiro JJ, Freitas VM, Moretti AI, Jorge AJ, Jaeger RG. Local invasiveness of ameloblastoma. Role played by matrix metalloproteinases and proliferative activity. Histopathology. 2004; 45:65-72.

156. Rothenberg ML, Nelson AR, Hande KR. New drugs on the horizon: matrix metalloproteinase inhibitors. Oncologist. 1998; 3:271-4.

157. Folgueras AR, Pendas AM, Sanchez LM, Lopez-Otin C. Matrix metalloproteinases in cancer: from new functions to improved inhibition stratageis. Int J Dev Biol. 2004; 48:411-24.

158. Hsu SM, Raine L, Fanger H. Use of avidin-biotin-peroxiodase complex $(\mathrm{ABC})$ in immunoperoxidase techniques: a comparison between $\mathrm{ABC}$ and unlabeled antibody (PAP) procedures. J Histochem Cytochem. 1981; 29:2836. 
159. Franc B, Rosenberg-Bourgin M, caillou B, Dutrieux-Berger N, Floquet J, Houcke-Lecomte M, Justrabo E, Lange F, Labat-Moleur F, Le Bodic MF, Patey M, Beauchet A, Saint-André JP, Hejblum G, Viennet G. Medullary thyroid carcinoma: search for histological predictors of survival (109 proband cases analysis). Hum Pathol. 1998; 29:1078-84.

160. Guyetant S, Dupre F, Bigorgne JC, Franc B, Dutrieux-Berger N, LecomteHoucke M, Patey M, Caillou B, Viennet G, Guerin O, Saint-Andre JP. Medullary thyroid microcarcinoma: a clinicopathologic retrospective study of 38 patients with no prior familial disease. Hum Pathol. 1999; 30:957-63.

161. Niccoli-Sire P, Murat A, Rohmer V, Gibelin H, Chabrier G, Conte-Devolx B, Visset J, Ronceray J, Jaeck D, Henry JF, Proye C, Carnaille B, Kraimps JL; Groupe D'etude Des Tumeurs Endocrines. When should thyroidectomy be performed in familial medullary thyroid carcinoma gene carriers with noncysteine RET mutation? Surgery. 2003:134:1029-36.

162. Hofmann A, Laue S, Rost A -K, Scherbaum WA, Aust G. mRNA levels of membrane-type 1 matrix metalloproteinase (MT1-MMP), MMP-2, and MMP-9 and of their inhibitors TIMP-2 and TIMP-3 in normal thyrocytes and thyroid carcinoma cell lines. Thyroid. 1998: 8:203-14.

163. Patel A, Straight AM, Mann H, Duffy E, Fenton C, Dinauer C, Tuttle RM, Francis GL. Matrix metalloproteinase (MMP) expression by differentiated thyroid carcinoma of children and adolescents. J Endocrinol Invest. 2002: 25:403-8.

164. Baldini E, Toller M, Graziano FM, Russo FP, Pepe M, Biordi L, Marchioni E, Curcio F, Ulisse S, Ambesi-Impiombato FS, D'Armiento M. Expression of matrix metalloproteinases and their specific inhibitors in normal and different human thyroid tumor cell lines. Thyroid. 2004: 14:881-8.

165. Sato H, Takino T, Okada Y, Cao J, Shinagawa A, Yamamoto E, Seiki M. A matrix metalloproteinase expressed on the surface of invasive tumour cells. Nature. 1994: 370:61-5. 
